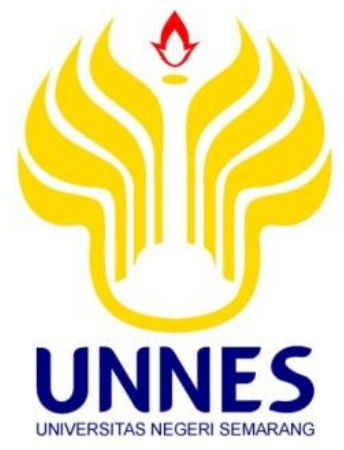

SKRIPSI

MARCHING BAND SMP PANGUDI LUHUR DOMENICO SAVIO SEMARANG

KAJIAN : ARANSEMEN DAN MANAJEMEN

Diajukan dalam Rangka Penyelesaian Studi Strata 1 Untuk Mencapai Gelar Sarjana Pendidikan

Oleh

Iyar Ekklesia Putra Wibawa 2501412005

Pendidikan Seni Musik

FAKULTAS BAHASA DAN SENI

UNIVERSITAS NEGERI SEMARANG

2016 


\section{PENGESAHAN KELLULUSAN}

Skripsi ini telah dipertahankan dihsdapes sidanog Panitia Ojian Skripei Jurwan

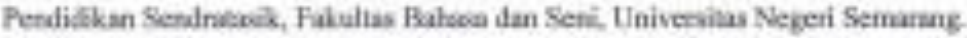

Padn. Hari

Tangigal :

\section{Panitis Ujian Ssripei}

Pwof. DR. Muhummad Jacull, M.Hum. (19610704198833t003)

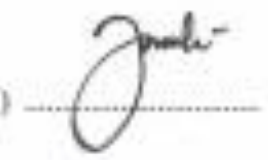

Ketui

Dos. Suharia, S.Pd. M. Tham

Sekretaris

Dek Siti Aesijah, M. PA.

Perregit I

Abdel Rachmon, S F.M.P.

Peaguji 2

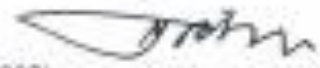

$(196510 t 819900 t 002)$

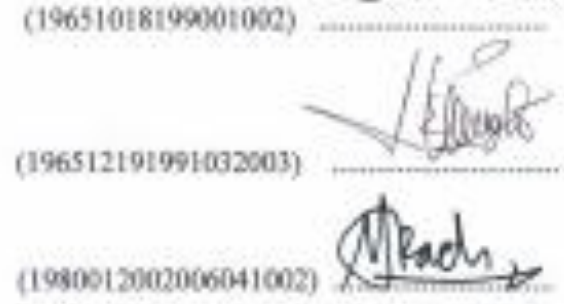

Der. Syahnil Sych Sinaga, M.Hum. Peryigi 3

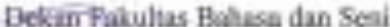

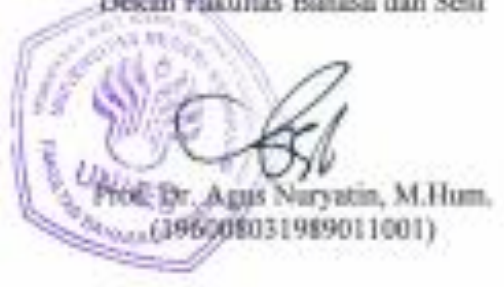




\section{PERNYATAAN}

Dengan ini saya

$\begin{array}{ll}\text { Nama } & : \text { Iyar Ekklesia Putra Wibawa } \\ \text { NIM } & : 2501412005 \\ \text { Prodi/jurusan } & \text { : Pendidikan Seni Musik/SENDRATASIK }\end{array}$

Menyatakan bahwa skripsi yang berjudul "MARCHING BAND SMP PANGUDI LUHUR DOMENICO SAVIO SEMARANG KAJIAN : ARANSEMEN

DAN MANAJEMEN", yang saya tulis dalam rangka menyelesaikan salah satu syarat untuk memperoleh gelar sarjana pendidikan ini benar-benar karya saya sendiri, yang saya selesaikan melalui proses penelitian, bimbingan, diskusi dan pemaparan ujian. Semua kutipan, baik yang langsung maupun tidak langsung, baik yang diperoleh dari sumber perpustakaan, wahana elektronik, wawancara langsung maupun sumber lainya, telah disertai keterangan mengenai identitas narasumbernya dengan cara sebagaimana lazimnya dalam penulisan karya ilmiah.

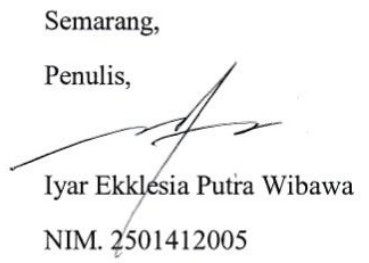

iii 


\section{SARI}

Wibawa, Iyar Ekklesia Putra. 2016. "MARCHING BAND SMP PANGUDI LUHUR DOMENICO SAVIO SEMARANG KAJIAN : ARANSEMEN DAN MANAJEMEN". Skripsi Jurusan Seni Darama Tari dan Musik, Fakultas Bahasa dan Seni, Unniversitas Negeri Semarang. Pembimbing I Drs. Syahrul Syah Sinaga, M.Hum, Pembimbing II Abdul Rachman, S .Pd.,M.Pd.

Marching Band adalah kegiatan ektrakurikuler SMP Pangudi Luhur Domenico Savio Semarang. Marching Band tersebut dahulu pernah aktif dan berkembang, seiring dengan berjalannya waktu Marching Band tersebut vakum selama delapan belas tahun. Dengan dukungan dari pihak orang tua wali, alumni, dan pihak sekolah Marching Band dapat kembali aktif dan berprestasi. Perolehan prestasi tidak lepas dari segi musikalitas, yaitu aransemen lagu dan manajemen dalam Marching Band Domenico Savio Semarang. Dari masalah tersebut peneliti tertarik pada aransemen dan manajemen, tujuan untuk mengetahui bagaimana aransemen dan manajemen yang ada pada Marching Band Domenico Savio Semarang.

Penelitian ini bersifat kualitatif. Bersifat kualitatif karena prosedur pemecahan masalah dilakukan dengan cara menganalisa, menggambarkan, keadaan objek, dengan menggunakan pendekatan musikologi dan manajemen pertunjukan. Teknik mengambil data dengan teknik observasi, wawancara, dan dokumentasi. Teknik analisis data dengan teknik reduksi data, penyajian data, dan verifikasi data.

Hasil penelitian ini adalah sebagai berikut: aransemen pada bagian ritme sebagian besar menggunakan tiga pola yaitu $\mathrm{A}, \mathrm{B}$, dan $\mathrm{C}$ pola ritmenya yang dimainkan snare drum terdapat bagian yang memakai not triol pada bagian lagu, snare drum dan quartom pada aransemen tersebut banyak menggunakan teknik ring shoot dan teknik roll dan pola ritmenya pun menggunakan sinkopasi pada pertengahan lagu yang menuju ke bagian interlude. Pada bagian melodi, pemegang melodi utama adalah mellophone dan ada nada yang ditiup sangat panjang yaitu selama 24 ketuk, melodi iringan lagu terdapat nuansa musik jawa, pada vibraphone nada yang dimainkan nada pembalikan akor secara arrpegio. Pada akor menggunnakan akor sekunder dan pembalikan dimainkan oleh tuba dan baritone secara long tone dan stacato, nadanya sangat rendah. Manajemen ternyata sudah diterapkan, sehingga perencanaan, pengorganisasian, penggerakan, dan pengawasan dapat berjalan dengan baik dan pihak dari luar Marching Band Domenico Savio Semarang, yaitu perwakilan orang tua murid serta para alumni dilibatkan untuk mengelola Marching Band Domenico Savio Semarang dalam kepengurusan.

Saran dari peneletian ini, peserta harus latihan sangat ekstra untuk memperoleh teknik permainan alat musik yang baik, ini menyebabkan peserta akan kekurangan waktu untuk belajar pelajaran akademik. Dalam manajemen sudah berjalan baik dengan menerapkan aspek dasar menajemen untuk mengelola Marching Band Domenico Savio Semarang, namun terdapat kekurangan pada peremajaan alat dimana masih banyak alat yang belum diperbaiki. 


\section{PRAKATA}

Puji Syukur, senantiasa penulis panjatkan kepada Tuhan Yesus Kristus di Surga karena hanya dengan anugrahNYA, penulis dapat menyelesaikan skripsi yang berjudul "MARCHING BAND SMP PANGUDI LUHUR DOMENICO SAVIO SEMARANG KAJIAN : ARANSEMEN \& MANAJEMEN" sebagai persyaratan untuk meraih gelar sarjana pendidikan.

Penulis menyadari dengan sepenuh hati bahwa tersusunnya skripsi ini bukan hanya atas kemampuan dan usaha penulis semata, namun juga berkat bantuan dari berbagai pihak. Oleh karena itu, pada kesempatan kali ini penulis mengucapkan terimakasih yang sedalam-dalamnya kepada yang terhormat:

1. Prof. Dr. Fathur Rokhman, M.Hum. Rektor Universitas Negeri Semarang, yang telah memberikan kesempatan untuk menimba ilmu di Universitas Negeri Semarang.

2. Prof. Dr. Agus Nuryatin, M.Hum. Dekan Fakultas Bahasa dan Seni Universitas Negeri Semarang yang telah memberikan izin penelitian.

3. Dr. Udi Utomo, M.Si. Ketua Jurusan Pendidikan Seni Drama Tari dan Musik yang telah memberikan fasilitas pada penyusun skripsi ini.

4. Drs. Syahrul Syah Sinaga, M.Hum. (Dosen Pembimbing I) yang telah memberikan bimbingan, pengarahan, masukan, dan motivasi kepada penulis sehingga dapat menyelesaikan skripsi ini. 
5. Abdul Rachman, S .Pd.,M.Pd (Dosen Pembimbing II) yang telah memberikan bimbingan, pengarahan, masukan, dan motivasi kepada penulis sehingga dapat menyelesaikan skripsi ini.

6. Bapak dan Ibu Dosen Jurusan Pendidikan Seni Musik yang telah memberikan bekal ilmu dan pengetahuan sehingga penulis mampu menyelesaikan penyusunan skripsi ini.

7. Bapak Albertus Suwarto, FIC, M.Pd dan Ibu Maria Yosefta Mariatmi selaku kepala sekolah SMP Pangudi Luhur Domenico Savio Semarang dan pembina Marching Band Domenico Savio Semarang yang telah memberikan izin penelitian dan segala fasilitas selama penulis melakukan penelitian.

8. Suroso, Setiana Eka Rini, S.Pd., dan Mochamad Rochaimin. Selaku pelatih Marching Band Domenico Savio Semarang yang telah memberikan arahan dan fasilitas dalam proses penelitian.

9. Asih Budi Lestari dan teman-teman yang telah memberikan masukan, nasehat, dan motivasi.

10.Seluruh pihak yang tidak bisa penulis sebutkan satu persatu yang telah memberikan bantuan dan dorongan baik material maupun spiritual sehingga skripsi ini dapat terselesaikan. semua.

Penulis berharap semoga skripsi ini dapat bermanfaat bagi para pembaca Semarang, Mei 2016 


\section{MOTTO DAN PERSEMBAHAN}

\section{Motto:}

"Di dalam kesesakan dan di dalam kemenangan aku tahu Engkau bersamaku" Ia seperti pohon yang ditanam ditepi aliran air, yang menghasilkan buahnya pada musimnya, dan yang tidak layu daunnya, apa saja yang diperbuatnya berhasil ( Mazmur $1: 3$ )

Persembahan:

1. Ibu Setyo Pulihati (Alm) dan Bapak Sarno tercinta atas doa, cinta dan kasih sayang yang tiada hentinya.

2. Kakak dan adiku, Mas Eyben, Dek Ayuk dan seluruh keluarga besar yang selalu mendukung dan memotivasi.

3. Keluarga besar Sabda Kinnara Unnes Marching Band.

4. Teman-temanku yang selalu mendoakan dan memberi semangat. 


\section{DAFTAR ISI}

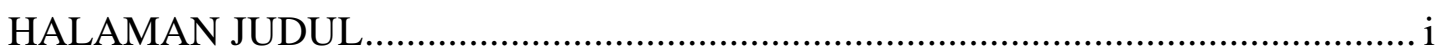

LEMBAR PENGESAHAN ...................................................................... ii

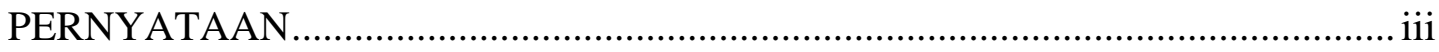

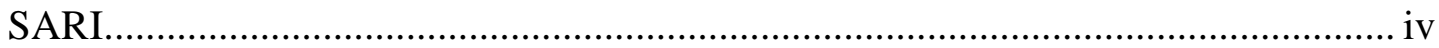

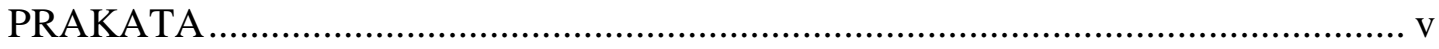

MOTO DAN PERSEMBAHAN ................................................................ vii

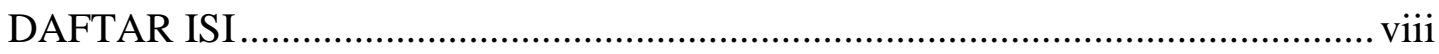

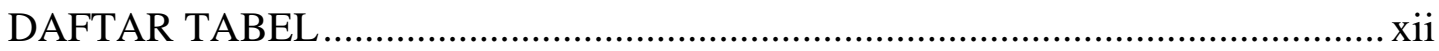

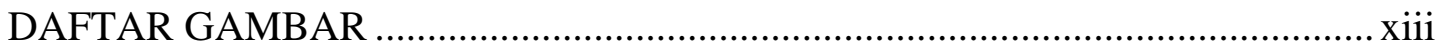

DAFTAR BAGAN ...................................................................................

BAB 1 PENDAHULUAN ......................................................................... 1

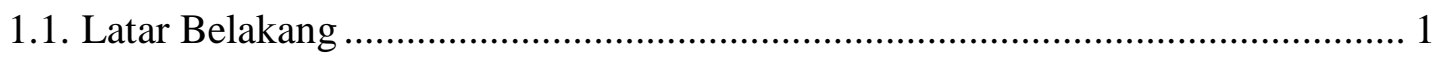

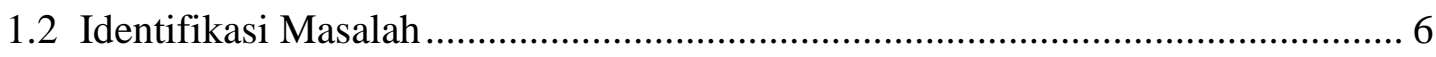

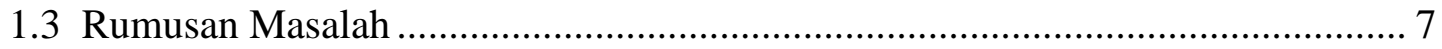

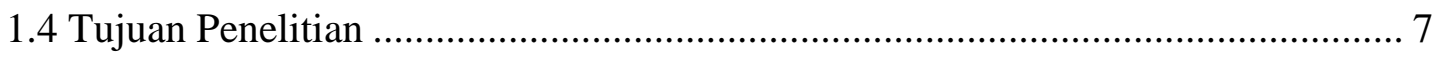

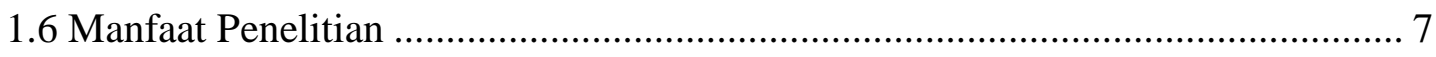

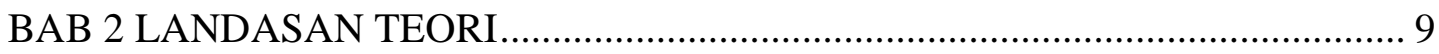

2.1 Marching Band..................................................................................... 9

2.2.1 Pengertian Marching Band...................................................................... 9

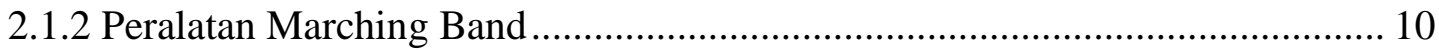

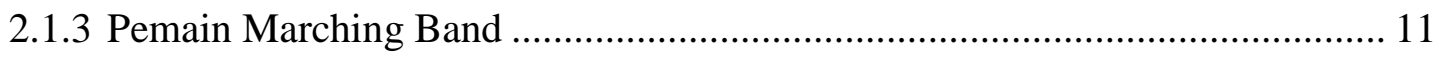




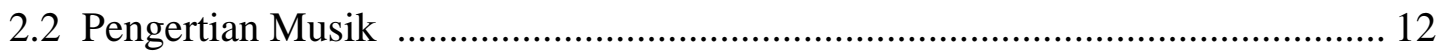

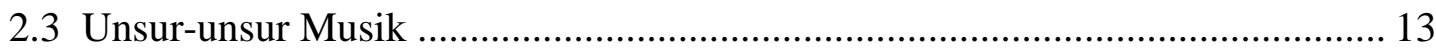

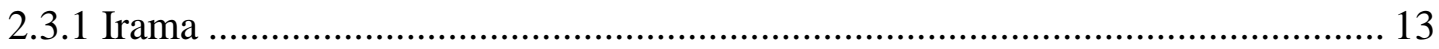

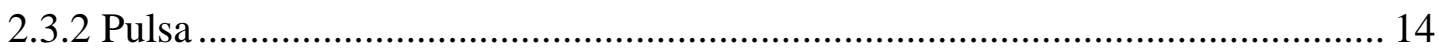

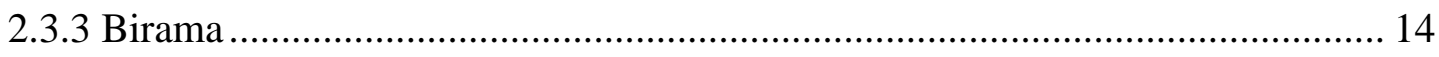

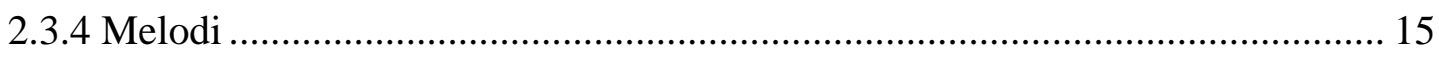

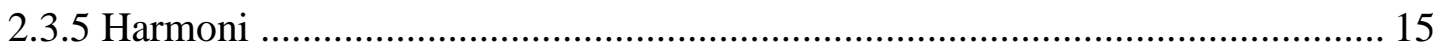

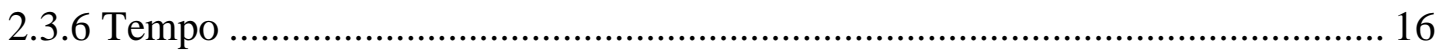

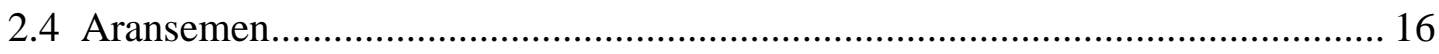

2.4.1 Pengertian Aransemen .................................................................................. 16

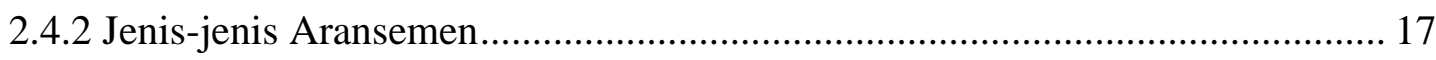

2.5 Komponen-komponen Aransemen................................................................ 19

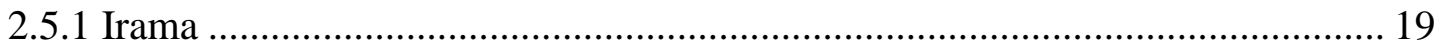

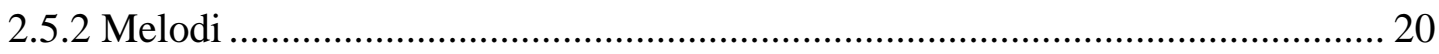

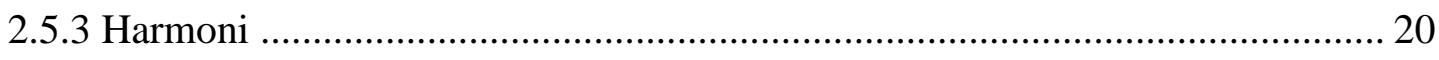

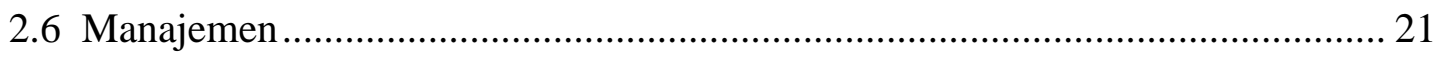

2.6.1 Pengertian Manajemen............................................................................. 21

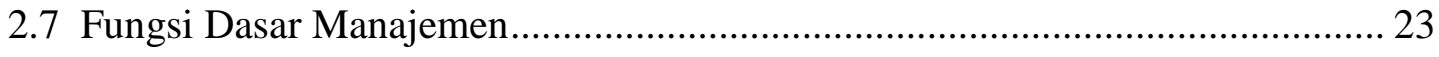

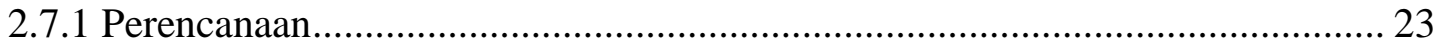

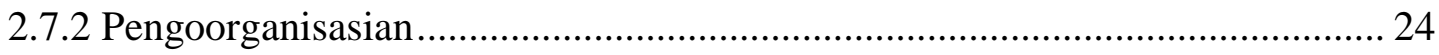

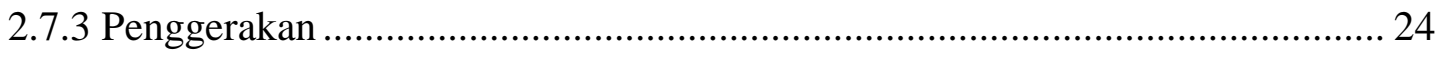

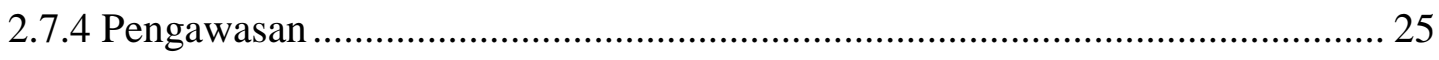

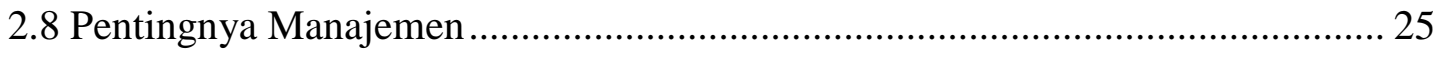

2.9 Faktor-faktor Manajemen .............................................................................. 27

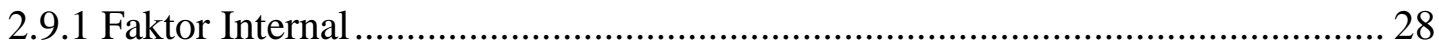




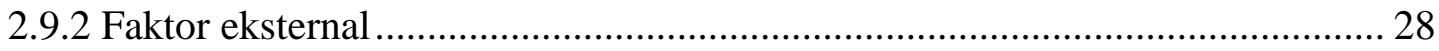

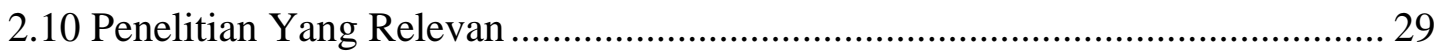

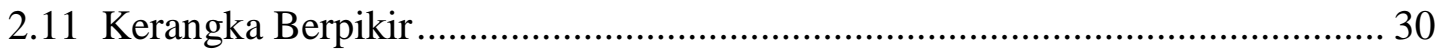

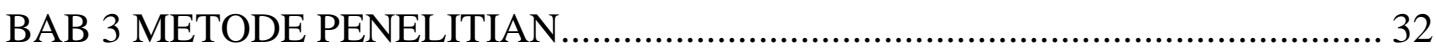

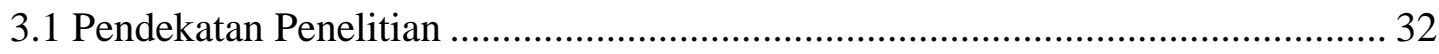

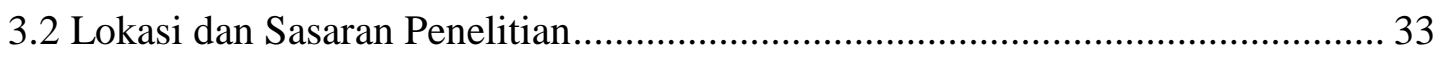

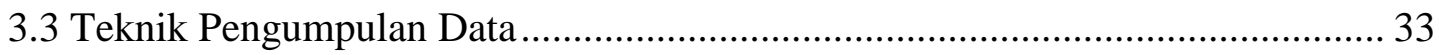

3.3.1 Teknik Observasi ………………………………………………………..... 33

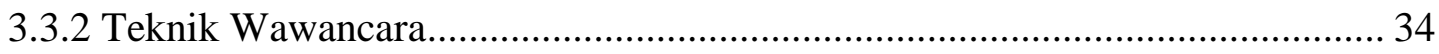

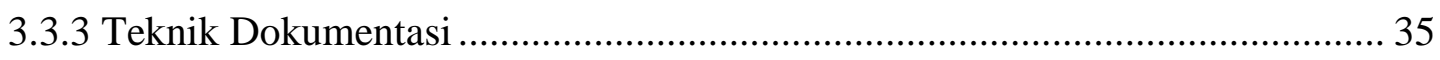

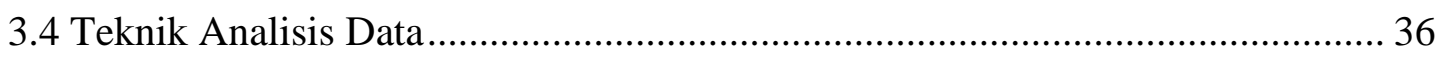

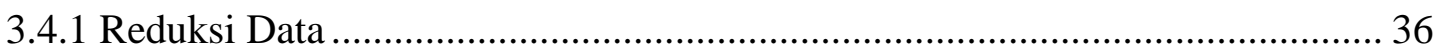

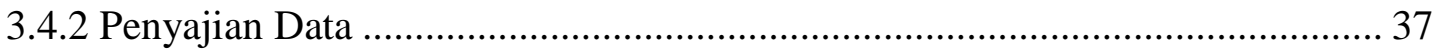

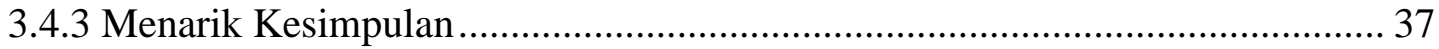

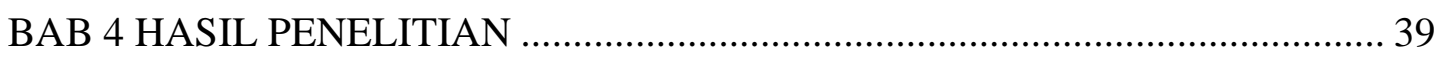

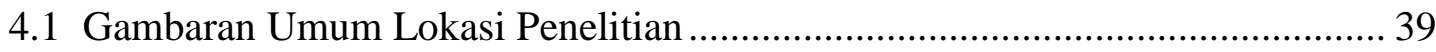

4.1.1 Lokasi SMP Pangudi Luhur Domenico Savio Semarang .................................. 39

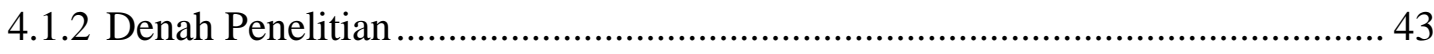

4.1.3 Gambaran Umum Marching Domenico Savio Semarang ................................. 44

4.1.4 Sejarah Singkat Marching Domenico Savio Semarang .................................... 45

4.1.5 Struktur Pemain Marching Domenico Savio Semarang ................................... 46

4.2 Aransemen Marching Band Domenico Savio pada lagu Untukku ...................... 49

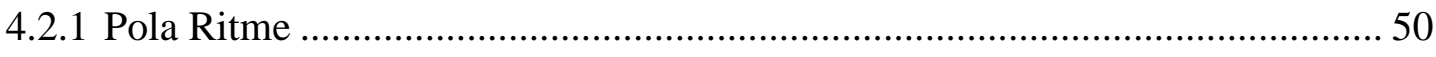

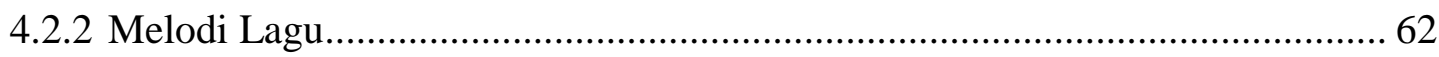

4.2.3 Akor yang digunakan dalam arensemen lagu untukku..................................... 77

4.3 Manajemen Marching Band Domenico Savio Semarang ..................................... 83 


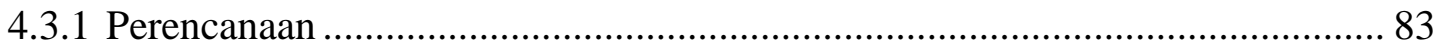

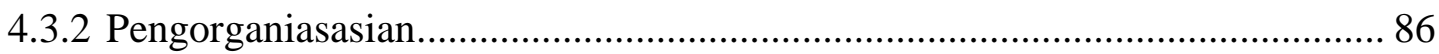

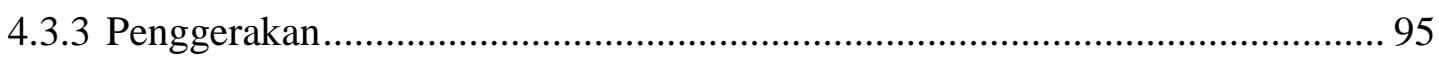

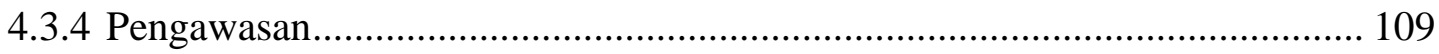

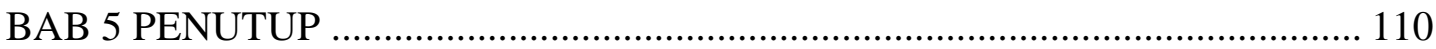

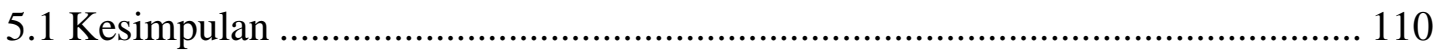

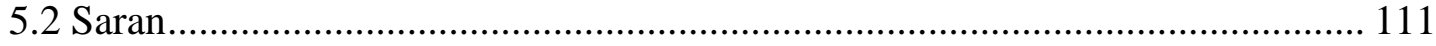

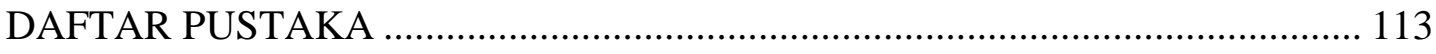

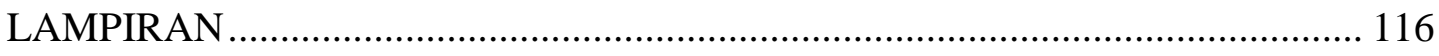




\section{DAFTAR TABEL}

Tabel 1 Kegiatan ekstrakurikuler SMP Domenico Savio ........................................ 42

Tabel 2 Struktur pemain Marching Band Domenico Savio ...................................... 46

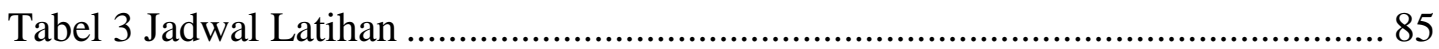

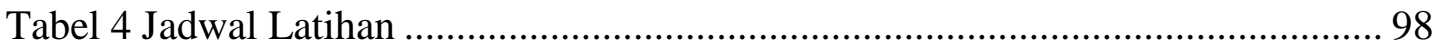

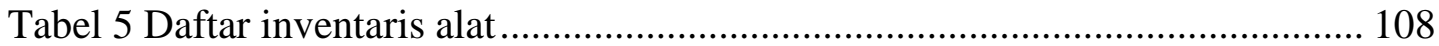




\section{DAFTAR GAMBAR}

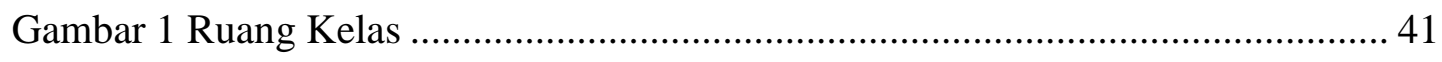

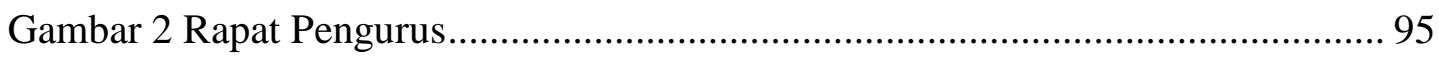

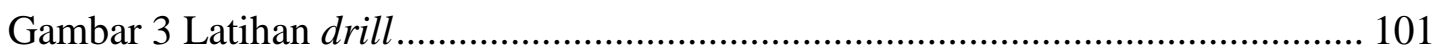

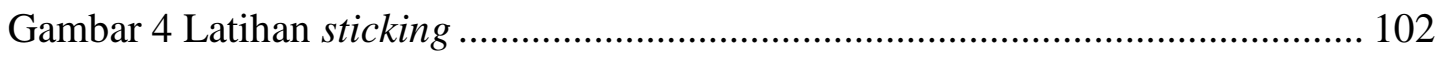

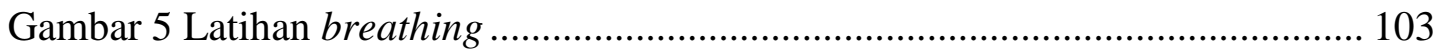

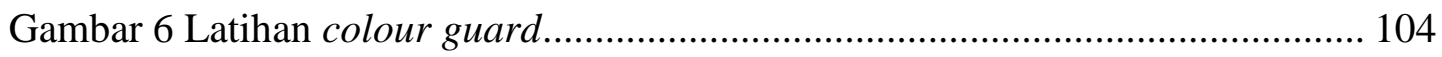

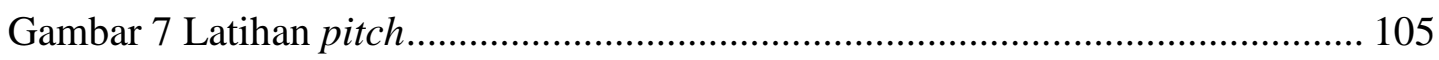




\section{DAFTAR BAGAN}

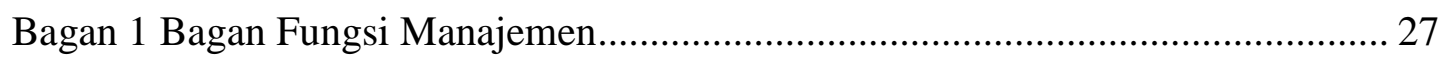

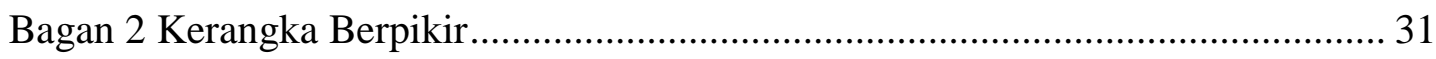

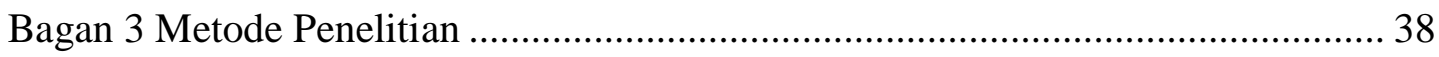

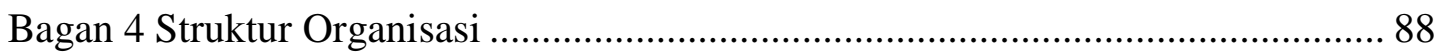




\section{PENDAHULUAN}

\subsection{Latar Belakang}

Di dalam kehidupan sehari-hari manusia tidak akan terlepas dari kesenian, kesenian merupakan hasil dari sebuah budaya, dan menjadi sebuah wahana untuk mengekspresikan rasa keindahan yang timbul dari dalam jiwa manusia. Di samping menjadi sarana penyampai rasa keindahan, kesenian juga memiliki fungsi lain, seperti simbol dari suatu perkumpulan, dimana di dalam perkumpulan tersebut mempunyai adat dan nilai-nilai kebudayaan. Menurut (Koentjaraningrat, 1974:23) keseniaan dapat berfungsi untuk mempererat ikatan solidaritas suatu masyarakat.

Seni adalah ciptaan manusia yang disampaikan melalui rasa indah yang terkandung dalam setiap jiwa manusia, seni diciptakan melalui suatu perantara atau alat-alat komunikasi yang memiliki berbagai ragam bentuk yang bisa di tangkap oleh indra yang ada di dalam tubuh manusia, seperti indra penglihatan (rupa), indra pendengaran suara (suara), ataupun diciptakan memalui dengan sebuah gerakan (tari) .

Musik adalah salah satu bagian dari sebuah kesenian, kesenian merupakan salah satu unsur dari sebuah kebudayaan (Koentjaranigrat, 1986 :203-204). Di dalam kehidupan sehari-hari kita dapat mengetahui bahwa sebuah kesenian terdapat musik, yang memiliki fungsi sebagai identitas dari suatu kebudayaan yang ada di dalam masyarakat. 
World Book Ensyclopedy Music (1996 : 27), menjelaskan bahwa musik adalah seni yang tertua dalam peradaban umat manusia, baik dalam kehidupan sehari-hari maupun pada keagamaan. Musik telah ada di dalam kehidupan manusia selama berabad-abad, sekarang ini musik menjadi salah satu kebutuhan yang wajib bagi setiap manusia, musik juga berperan sebagai sarana hiburan dalam merubah suasana (mood), sebagai penyemangat, dan pada zaman sekarang musik tidak hanya sebagai sarana untuk menghibur, akan tetapi sebagai suatu prestis bagi kelompok tertentu dalam sebuah peraihan gelar dalam perlombaan atau festival.

Marching Band merupakan bentuk musik yang berasal dari barat, Marching Band hadir di Indonesia melalui proses bertahap dan panjang dimana dahulu bentuk musik tersebut berkembang hanya pada kalangan militer, lambat laun salah satu bentuk musik lapangan tersebut mulai diterima oleh masyarakat dan terilihat jelas keberadaanya di masyarakat sekarang ini. Menurut (Udi Utomo, 1993 : 80 ) Marching Band walaupun juga merupakan satuan musik lapangan namun faktor musikalitas dari alat-alat melodis sangat diutamakan. Dengan demikian dapat dikatakan bahwa marching band adalah sekelompok barisan orang yang memainkan musik secara ansambel serta terdapat unsur olahraga dalam setiap penampilannya. Penampilan marching band merupakan kombinasi dari permainan musik (tiup dan perkusi) serta aksi baris-berbaris dari pemainnya (Display). Umumnya, penampilan marching band dipimpin oleh satu atau dua orang komandan lapangan (field commender) serta dilakukan baik di lapangan terbuka maupun di lapangan tertutup dalam barisan yang membentuk formasi dengan pola yang senantiasa berubah-ubah sesuai dengan alur koreografi terhadap 
lagu dan diiringi pula dengan aksi tarian yang dilakukan oleh sejumlah pemain bendera (colour guard).

Dalam permainan Marching Band mengandung nilai disiplin, nilai kebersamaan, nilai tanggung jawab, dan nilai keindahan yang sangat dominan, sebagai musik yang berbentuk secara ansambel, saat bermain Marching Band di bawah seorang komandan (field commander) masing-masing personel dituntut untuk bertanggung jawab dalam menjalin kekompakan dan keharmonisasian serta diwajibkan melakukan aktivitas-aktivitas lain, seperti baris-berbaris atau gerakan yang telah ditentukan saat bermain musik.

Nilai-nilai yang terkandung di dalam permainan Marching Band tersebut, menjadi salah satu faktor Marching Band masuk dalam instansi pendidikan yaitu sekolah, melalui kegiatan ekstrakurikuler. Maksud dari ekstrakurikuler adalah kegiatan atau aktivitas siswa yang dilakukan setelah jam sekolah berakhir atau di luar jam sekolah, menurut Rusli Lutan (1986 : 72) program ekstrakurikuler merupakan bagian internal dari proses belajar yang menekankan pada pemenuhan kebutuhan anak didik. Dapat dipahami secara sederhana bahwa ekstrakurikuler menjadi salah satu wadah untuk menyalurkan bakat, hobi, dan minat pada siswa dengan positif serta menumbuhkan daya kreativitas, rasa percaya diri, dan rasa tanggung jawab.

Ekstrakurikuler yang ada di sekolah sekarang sangat banyak macamnya seperti : paduan suara, karya ilmiah remaja, futsal, basket, dan Marching Band, ekstrakurikuler juga bukan hanya sebagai penyaluran hobi dan bakat, namun 
sebagai salah satu identitas bagi sekolah bahwa sekolah tersebut mampu berprestasi melalui perlombaan-perlombaan ekstrakulikuler.

Perlombaan atau festival musik pada saat ini mempunyai berbagai macam bentuk untuk disajikan, contoh dari sebuah perlombaan musik seperti: perlombaan paduan suara, perlombaan band, perlombaan musik instrumental, dan perlombaan Marching Band. Dalam perlombaan ekstrakurikuler, ada yang tingkat daerah ada pula yang tingkat nasional, contoh perlombaan musik Marching Band yaitu: Jateng Open, Hamengkubuwono Cup (HBCUP), Grand Prix Marching Band (GPMB), dan Grand Prix Junior Band (GPJB ). Perlombaan tersebut diadakan untuk menggali kreativitas dari sebuah kelompok serta menjadi suatu simbol terhadap prestasi yang diraih oleh sebuah kelompok.

Didalam perlombaan musik atau festival musik khususnya Marching Band, aransemen lagu merupakan suatu hal yang penting, selain untuk memberikan sajian musik kepada penonton lomba, aransemen lagu juga digunakan untuk meraih sebuah peraihan gelar, sebab dalam perlombaan Marching Band aransemen lagu merupakan salah satu poin yang akan dinilai. Penilaian yang dinilai dalam perlombaan Marching Band sangatlah banyak seperti, baris-berbaris, kekompakan bermain musik, manuvering pola berjalan, penguasaan lagu, teknik memegang alat, kostum, keseragaman gerak, konsep yang dibawakan, dan kerapian, semua hal tersebut merupakan yang menjadi faktor dalam penentuan kemenangan. Untuk mendapatkan aransemen lagu dalam Marching Band, untuk mendapatkan sumber daya yang loyal dan baik, untuk mendapatkan sebuah tujuan (perihan gelar), serta untuk mengatur sebuah team untuk menjadi solid maka perlu 
menggunakan manajemen, agar segalanya dapat diatur dan diarahkan supaya mendapatkan tujuan yang maksimal.

Salah satu kegiatan ekstrakurikuler musik yang ada di Sekolah Menengah Pertama Pangudi Luhur Domenico Savio Semarang adalah Marching Band, kegiatan ekstrakurikuler tersebut merupakan salah satu kegiatan yang ditawarkan oleh pihak sekolah kepada siswa. Marching Band Domenico Savio bernaung di bawah yayasan Pangudi Luhur yang memiliki alamat di Jl. Dr. Sutomo No.6, Semarang Jawa Tengah 50224.

Sejarah Marching Band Domenico Savio Semarang berdiri pada tahun 1984 ditahun tersebut yang pertama kali terbentuk adalah Drum Band setelah dua tahun tepatnya ditahun 1986 baru terbentuk Marching Band, prestasi yang diraih oleh Marching Band Domsav, yaitu pernah mengikuti kejuaraan Grand Prix Marching Band (GPMB) pada tahun 1996 sebagai finalis di kejuaraan tersebut, hal tersebut merupakan hal yang terakhir setelah tahun 1996 Marching Band Domenico Savio tidak aktif kembali dikarenakan minat peserta yang menurun dan kurangnya pengelolaan oleh pihak sekolah. Setelah delapan belas tahun vakum dari kegiatan ekstrakurikuler dan perlombaan-perlombaan, hal ini mengusik hati para alumni yang pernah ikut marching band, untuk mengaktifkan kembali Marching Band Domenico Savio dalam mengikuti perlombaan-perlombaan dan ikut mengelola kembali manajemen Marching Band Domenico Savio. Tepatnya dibulan September tahun 2014 Marching Band tersebut mencoba bangkit kembali untuk mengikuti perlombaan pertamanya yaitu Hamengkubuwono Cup (HBCUP) pada bulan Mei 2015 yang diselenggarakan di Yogyakarta dengan menggunakan 
aransemen lagu baru dan manajemen yang baru, ternyata hasil dari latihan selama delapan bulan menghasilkan prestasi yang cukup baik, dimana Marching Band Domenico Savio Semarang menjadi juara umum diwaktu itu.

Setelah perlombaan tersebut Marching Band Domenico Savio mengikuti perlombaan di Jateng Open 2015 yang diselenggarakan di Semarang meraih gelar sebagai juara dua, dan mengikuti kembali perlombaan Grand Prix Junior Band (GPJB) 2015 yang diselenggarakan di Jakarta hasil dari perlombaan tersebut menjadikan Marching Band Domenico Savio sebagai juara harapan tiga. Hal tersebut sangatlah luar biasa, apabila melihat dari sisi kemunculan kembalinya Marching Band Domenico Savio Semarang selama delapan belas tahun vakum dari perlombaan-perlombaan marching band dan setelah kembali lagi mengikuti perlombaan dengan aransemen lagu baru dan manajemen yangb baru dari pihak pengurus yang baru, Marching Band SMP Pangudi Luhur Domenico Savio Semarang dapat memiliki prestasi yang membanggakan.

\subsection{Indentifikasi Masalah}

Berdasarkan latar belakang masalah di atas, pengidentifikasian masalah berdasarkan pada aransemen lagu dan manajemen Marching Band Domenico Savio. Dimana penulis melihat aransemen lagu yang ada pada Marching Band Domenico Savio ternyata dapat meraih prestasi yang membanggakan serta manajemen yang diterapkan oleh Marching Band Domenico Savio menghasilkan prestasi yang membanggakan, prestasi yang didapat adalah prestasi tingkat di nasional dan di daerah. Tidak membutuhkan waktu yang lama yaitu kurang dari setahun untuk membangkitkan kembali Marching Band Domenico Savio 
Semarang yang dulunya tidak aktif dan setelah aktif lagi, Marching Band Domenico Savio Semarang dapat meraih prestasi yang luar membanggakan. Hal tersebut membuat penulis tertarik untuk meneliti bagaimana aransemen lagu yang serta manajemen yang di terapkan oleh Marching Band Domenico Savio

\subsection{Rumusan Masalah}

Dari latar belakang yang diuraikan di atas, maka dapat dirumuskan masalah sebagai berikut:

1. Bagaimana aransemen lagu Marching Band di SMP Pangudi Luhur Domenico Savio Semarang?

2. Bagaimana manajemen Marching Band di SMP Pangudi Luhur Domenico Savio Semarang?

\subsection{Tujuan Penelitian}

Tujuan dari penelitian ini sebagai berikut:

1. Untuk mengetahui aransemen lagu Marching Band di SMP Pangudi Luhur Domenico Savio Semarang.

2. Untuk mengetahui manajemen Marching Band di SMP Pangudi Luhur Domenico Savio Semarang.

\subsection{Manfaat Penelitian}

Hasil penelitian ini diharapkan memeberi manfaat :

1. Secara teoritis :

1.1. Sebagai bahan / acuan bagi peneliti lain.

2. Secara praktis : 
2.1. Sebagai informasi bagi Marching Band lain tentang aransemen lagu serta manajemen.

2.2.Sebagai informasi bagai masyarakat tentang aransemen marching band dan menajemen marching band.

2.3.Bagi peneliti sendiri, untuk menambah pengetahuan tentang penerapan manajemen modern pada Marching Band SMP Pangudi Luhur Domenico Savio Semarang.

2.4.Bagi peneliti sendiri, untuk menambah pengetahuan tentang aransemen Marching Band SMP Pangudi Luhur Domenico Savio Semarang yang digunakan dalam lomba.

2.5.Bagi pembaca, dapat digunakan sebagai salah satau sumber informasi khususnya mengenai pengelolaan Marching Band. 


\section{BAB 2}

\section{LANDASAN TEORI}

\subsection{Marching Band}

\subsubsection{Pengertian Marching Band}

Menurut (Udi Utomo, 1993 : 75) kata “marching” mengandung pengertian bahwa musik yang dimainkan merupakan bentuk permainan musik untuk mengiringi langkah dalam berbaris atau dengan kata lain berbaris sambil bermain musik. Sedangkan kata "band" mengadung pengertian kesatuan besar pemain musik. Marching band merupakan salah satu jenis musik yang dalam permainannya menggunakan karakter khusus yang dapat dilihat dengan kasat mata yaitu dengan baris-berbaris. Dengan demikian dapat disimpulkan bahwa marching band adalah sekelompok barisan orang yang memainkan musik secara ansambel serta terdapat unsur olahraga dalam setiap penampilannya. Penampilan marching band merupakan kombinasi dari permainan musik (tiup dan perkusi) serta aksi baris-berbaris dari pemainnya (Display), sekarang ini baris-berbaris lebih dikenal dengan nama "display" atau formasi yang telah ditentukan sebelumnya oleh pelatih, jadi saat seorang pemain marching bermain musik, saat itu juga seorang pemain harus "move" atau bergerak mengikuti seiringan dengan irama musik.

Bentuk musik pada marching band sudah sangat bervariasi, tidak hanya memainkan lagu mars saja, ini diwujudkan melalui: mars jalan, merupakan permainan dari alat perkusi jenis membran misalnya mars kavaleri, mars invantri berbaris, misalnya mars PDBI, maju tak gentar, halo-halo Bandung, dan lain-lain 
dan sudah nampak keterpaduan dan masing-masing kelompok alat tanpa ada salah satu kelompok alat yang mendominasi dalam permainan musik, lagu-lagu yang dimainkan meliputi lagu mars, lagu keroncong, daerah, pop dengan berbagai irama samba, slow rock (Irine Nurul Hidayah 2013 : 18)

\subsubsection{Peralatan Marching Band}

Dalam bermusik tidak akan lepas dari yang namanya instrument atau sering disebut dengan alat musik, marching band merupakan musik yang berpadu dengan olahraga, juga mempunyai alat tersendiri. Untuk lebih jelasnya diungkapkan oleh (Udi Utomo 1993 : 78 ) sebagai berikut:

1. Kelompok alat tiup ( aerophone )

1.1. Tiup logam, meliputi: bugle/sangkakala, trompet, cornet, mellophone, marching trombone, baritone, euphonium, tuba, sausaphone.

1.2. Tiup kayu, meliputi: piccolo, flute, saxophone (sopran, alto, dan tenor).

Walaupun dalam perkembangannya marching band di Indonesia lebih sering dan dominan menggunakan alat tiup logam dibandingkan dengan alat tiup kayu, biasanya alat tiup kayu hanya menjadi ornamen dalam setiap perlombaanperlombaan marching band pada umumnya. Umumnya instrument musik dalam permainan marching band menggunakan nada dasar $\mathrm{B}^{\mathrm{b}}$ atau nada dasar $\mathrm{F}$.

\section{Kelompok Alat Pukul ( perkusi)}

2.1. Jenis membran, meliputi: snare drum, tenor drum, bas drum, quint, timpani, dan cymbal. 
2.2. Jenis pejal, meliputi: marching cymbal, bell lyra, marimba, xylophone, vibraphone,

Instrument atau alat marching band yang berupa perkusi/pukul merupakan instrument yang dibawa oleh pemain dan dimainkan dalam barisan seperti instrument tiup. Dalam bermain perkusi sambil berjalan biasanya disebut dengan drumline atau battery. Sedangkan instrument pejal atau sekarang lebih dikenal dengan sebutan pitch, merupakan salah satu alat musik perkusi/pukul yang memiliki nada. Saat penampilan marching band kelompok pemain pitch ini bersifat statis atau tidak berubah, karena para pemain instrument pitch tidak ikut dalam barisan seperti pemain brass dan pemain perkusi, pemain pitch biasanya menempati dibagian depan lapangan yang digunakan dalam penampilan.

\subsubsection{Pemain Marching Band}

Dalam sebuah permainan musik terdapat istilah-istilah tentang nama personil pemain musik, kebanyakan orang sudah mengenal tentang istilah tersebut, sedangkan dalam marching band pun juga terdapat istilah-istilah tentang nama para pemain, serta peran pemain tersebut dalam permainan marching band. Berikut nama personil marching band beserta perannya:

\section{Field Commaender}

Field commaender merupakan komamdan tertinggi dalam marching band. Peran field commaender adalah memimpin seluruh pasukan ( pemain ) segala sesuatunya serta bertugas sebagai kondakter dalam memimpin sebuah lagu. 


\section{Hornline ( barisan tiup )}

Hornline merupakan barisan yang berupa sekumpulan pemain yang menggunakan alat tiup, hornline biasanya terdapat di bagian depan. Peran atau tugas dari hornline ini adalah sebagai melodi utama dalam permainan marching band.

\section{Percusion line ( barisan perkusi )}

Dalam marching band percusion line merupakan kumpulan orang yang memaikan alat perkusi dangan memebentuk sebuah barisan yang rapi. Peran dari pemain ini adalah sebagai pemegang ritmis dan tempo saat memainakan sebuah lagu.

\section{Colour Guard}

Pemain ini adalah pemain bendera yang bertiang ( flags ), tugas dari seorang colour guard adalah menarik perhatian penonton, dengan cara memainkan bendera, namun biasanya para pemain colour guard tidak hanya memainkan bendera saja, mereka juga terkadang memainkan hiasan-hiasan, seperti: kipas, bunga, dan topeng yang mendukung dengan tema lagu yang dibawakan oleh marching band.

\subsection{Pengertian Musik}

Menurut Brenstein \& Picker dalam (Candra Mukti Septian 2014: 7) mengatakan bahwa musik adalah suara-suara yang diorganisasikan dalam waktu dan memiliki nilai seni dan dapat digunakan sebagai alat untuk mengkespresikan ide dan emosi dari komposer kepada pendengarnya. Aristoteles mengatakan 
musik adalah sesuatu yang mempunyai kemampuan untuk mendamaikan hati yang gundah, memiliki terapi rekreatif dan menumbuhkan jiwa patriotisme (Amir Pasaribu, 1986: 25)

Musik adalah seni penataan bunyi secara cermat yang membentuk pola teratur dan merdu yang tercipta dari alat musik atau suara manusia, musik biasanya mengandung unsur ritme, melodi, harmoni, dan warna bunyi (Syukur, $2005: 17)$.

Dari beberapa teori di atas mengenai musik, dapat diambil kesimpulan bahwa musik adalah bunyi yang tersusun secara teratur dan menimbulkan kesan nyaman dan indah yang mengungkapkan pikiran dan perasaan manusia, melalui unsur musik yaitu ritme, melodi, warna melodi, dan harmoni yang didapat dari

suara atau bunyi alat musik dan suara manusia yang dapat menyenangkan telinga dan mengekspresikan ide, perasaan, emosi, atau suasana hati.

\subsection{Unsur - unsur Musik}

\subsubsection{Irama}

Irama dalam musik terbentuk oleh bunyi dan diam, dengan bermacammacam lama waktu dan panjang pendeknya, membentuk pola irama, bergerak menurut pulsa dalam ayunan irama (Soeharto, 1992: 51). Menurut Jamalus (1998:7) mengatakan bahwa irama dalah urutan rangkaian gerak yang menjadi unsur dalam sebuah musik. Irama berhubungan dengan panjang pendeknya sebuah not dan berat ringannya pada tekanan atau aksen pada not. Namun demikian, oleh teraturnya gerak maka irama tetap dapat dirasakan meskipun 
melodi diam, dan keteratuan tersebut menjadikan lagu lebih enak untuk didengar dan dirasakan (Jamalus, 1998: 56 ). Dari beberapa teori di atas, dapat dikatakan bahwa irama adalah urutan rangkaian gerak yang membentuk pola irama dan bergerak teratur sehingga menyebabkan lagu enak didengar dan dirasakan.

\subsubsection{Pulsa}

Pulsa ialah rangkaian denyutan berulang-ulang yang berlangsung secara teratur yang dapat dirasakan dan dihayati dalam musik. Saat sedang mendengarkan sebuah lagu, seringkali kita secara tidak sadar menghentakhentakan kaki kita kelantai atau mengetuk-ngetukan tangan atau benda yang berada di tangan kita. Ketukan yang berulang-ulang dan teratur itulah yang dinamakan pulsa-pulsa dalam sebuah lagu juga dapat kita rasakan saat kita menyanyikan lagu dengan tepuk tangan. Tepukan tangan kita yang berlang-ulang dan teratur itulah yang dimaksud dengan pulsa. http://edukasi.kompasiana. com/2010/09/unsur-unsur-musik-irama-dan-melodi-307423.html.

\subsubsection{Birama}

Birama ialah ayunan rangkaian gerak kelompok beberapa pulsa yang pulsa pertamanya mendapat aksen lebih kuat dari aksen lainnya, berlangsung secara berulang-ulang dan teratur. Birama akan lebih kita rasakan saat kita sedang memimpin sebuah penyajian musik, misal saat itu memimpin paduan suara pada saat upacara hari senin. Saat kita sedang memimpin kelompok paduan suara menyanyikan lagu dengan birama dua berarti ayunan rangkaian gerak tangan terdiri atas kelompok dua pulsa, dimana pulsa pertamanya mendapatkan aksen atau tekanan yang lebih kuat dari pulsa yang kedua. Demikian saat kita memimpin 
paduan suara menyanyikan lagu dengan birama tiga, empat, dan seterusnya. http;//www.annmeahira.com/seni-musik.html.

\subsubsection{Melodi}

Melodi adalah susunan rangkaian tiga nada atau lebih yang terdengar berurutan serta berirama dan mengungkapkan suatu gagasan (Yoyok, 2007: 70). Menurut (Widia Pekerti dkk, 2005 : 220 ) melodi adalah berbagai tinggi dan rendah nada dikombinasikan dengan nilai nada. Melodi adalah susunan nada yang diatur tinggi rendahnya, pola, dan harga nada sehingga menjadi kalimat lagu. Melodi merupakan elemen musik yang terdiri dari pergantian berbagai suara yang menjadi satu kesatuan, di antaranya adalah satu-kesatuan suara dengan penekanan yang berbeda, intonasi dan durasi yang hal ini akan menciptakan sebuah musik yang enak didengar.

\subsubsection{Harmoni}

Pada saat kita mendengarakan beberapa nada dibunyikan secara bersamsama dan suaranya selaras, maka suara itu dikatakan : harmonis. Yang dimaksud dengan harmonis menurut (Sugeng Basuki, B.A. dkk 1980 : 42) harmonis dalam musik atau nyanyian ialah paduan beberapa nada yang tidak sama tingginya dan kedengaran selaras serta merupakan satu kesatuan yang bulat, apabila tiga buah nada atau lebih, dipadu secara bersama-sama dan kedengaran selaras bunyinya maka terjadilah yang namanya akor. Untuk memahami secara sederhana tentang harmonis dapat kita dengar melalui sebuah akor, karena akor terjadi atau terbentuk melalui tiga buah nada atau lebih yang memiliki perbedaan tinggi dan 
rendah yang dimainkan secara serentak atau secara bersama, sehingga menimbulkan kesan indah dan bulat.

\subsubsection{Tempo}

Tempo adalah kecepatan lagu yang dituliskan berupa kata-kata dan berlaku untuk seluruh lagu dan istilah itu ditulis pada awal tulisan lagu (Soeharto, 1992 : 52). Sementara (Miller 2001 : 24) mengatakan bahwa tempo adalah sebuah istilah dari bahasa Italia yang secara harafiah berarti waktu, di dalam musik menunjukan pada kecepatan. Fungsi tempo ini dimaksudkan untuk mempermudah dalam menyanyikan lagu yang ada (Soeharto, 1992 : 56). Macam-macam tanda tempo menurut (Miller 2001:24) yaitu: Presto: Sangat capat, Allegro: Cepat, Vivace:hidup, Moderato: sedang, Andante: agak lambat, Andagio: lebih lambat dari Andante, Lento: Lambat, Largo: sangat lambat.

\subsection{Aransemen}

\subsubsection{Pengertian Aransemen}

Untuk mengerti tentang aransemen, kita tidak akan lepas dari sebuah komposisi, komposisi musik menurut Pono Banoe (2003 : 426) unsur bentuk komposisi adalah frasa, priode, bentuk lagu satu bagian, dua bagian tunggal, tiga bagian tunggal, dan bagian majemuk, tema dan variasi. Unsur komposisi musik adalah syair, ritme dan pola ritme, melodi, harmoni, dinamik, warna bunyi, tekstur. Unsur strukstur komposisi musik adalah motif, tema, variasi dan improvisasi. Dari pendapat tentang komposisi di atas dapat ditarik kesimpulan bahwa komposisi sebuah karya musik adalah karya musik yang ditulis secara 
lengkap untuk dimainkan oleh banyak orang tanpa harus menghadirkan pencipta atau pembuat komposisi tersebut.

Bermain musik tidaklah akan lepas dari yang namanya aransemen, baik itu musik yang bentuk penyajiannya secara vokal, bentuk isntrumental, dan bentuk campuran, semua bentuk musik tersebut baik secara disengaja maupun tidak, pasti untuk memeperindah penyajian akan membutuhkan aransemen. Menurut (Sugeng Basuki, B.A. dkk 1980 : 89) aransemen berarti pembuatan iringan atau nyanyian dengan mengatur atau mengubah tinggi nada pada bagian motif-motifnya. Aransemen berasal dari bahasa Belanda arangement yang artinya penyesuaian komposisi musik dengan suara penyanyi atau instrument musik yang didasarkan atas sebuah komposisi yang telah ada sehingga esensi musiknya tidak berubah. Dari teori para ahli di atas tentang aransemen, dapat dimaknai secara sederhana dengan demikian, aransemen adalah mengubah lagu yang sudah ada menjadi suatu bentuk lagu yang baru tanpa meninggalkan ciri khas dari lagu yang diaransemen tersebut.

\subsubsection{Jenis - jenis Aransemen}

Dalam mengaransemen terdapat tiga jenis aransemen, arensemen tersebut meliputi: 1.) Aransemen vokal, setiap lagu dapat disusun aransemen khusus vokal, yaitu dalam dua suara, tiga suara, empat suara. Untuk menyusun aransemen vokal, yang paling mudah adalah menyusun atransmen lagu dalam dua suara, karena untuk menyusun aransemen lagu dalam tiga dan empat suara ada banyak persyaratan yang harus diperhatikan. Untuk memperoleh hasil yang lebih baik dan memuaskan, setelah selesai disusun aransemen lagunya kemudian dicoba untuk 
dinyanyikan secara bersama-sama, apabila dirasa kurang baik/memuaskan maka dapat dicoba lagi untuk menyusun aransemen lagu tersebut hingga pada akhirnya diperoleh hasil yang sangat memuaskan. http;//mgmpseni.wordpress.com/materibelajar/seni-musik/semester-1/kelas-vii/aransemen-musik/.

Pendapat menegenai aransemen vokal dapat kita pahami secara sederhana bahwa aransemen vokal adalah aransemen yang dibentuk atau dibuat untuk suara manusia yang biasanya dibawakan dengan lagu tertentu, dalam aransemen tersebut terdapat beberapa suara yang berbeda, yaitu suara satu, dua, tiga, dan empat yang saling melengkapi satu dengan yang lainnya sehingga menimbulkan kesan yang indah. 2.) Aransemen insrument, dalam menyusun aransemen instrumen sangat berbeda dengan aransemen vokal. Untuk menyusun aransemen instrumen kita harus menyesuaikan dengan alat-alat musik yang dipergunakan. Semakin lengkap alat musik yang kita pergunakan, semakin banyak pula kemungkinan variasi yang dapat diciptakan. Untuk menyusun aransemen instrumen, kita harus berpedoman pada pengetahuan ilmu harmoni. Bagian-bagian dari suatu aransemen musik dikenal dengan istilah Partitur ( Belanda ), Partitura ( Italia ), Part ( Inggris ), Parte ( Perancis ). Dan dalam aransemen instrumen, kebanyakan partitur dimainkan bergantian. (http;//mgmpseni. wordpress. com/ materi-belajar/seni-musik/semester-1/kelas-vii/aransemen-musik/.)

Pendapat tersebut mengungkapakan bahwa aransemen isntrument musik diperuntukan bagi bunyi atau suara alat-alat musik dalam penyampaian sebuah lagu, dalam pembuatan aransemen isntrument harus memperhatikan alat musik yang ingin di aransemen, sebab alat musik satu dengan alat musik yang lain, nada 
dasarnya tidaklah sama maka dari itu untuk mengaransemen beberapa alat musik, setidaknya mengetahui ilmu tentang harmoni. 3.) Aransemen campuran, yang dimaksud aransemen campuran adalah campuran aransemen vokal dan instrumen. Teknik yang dilakukan adalah menggabungkan dua jenis aransemen yang telah ada. Dalam aransemen campuran pada umumnya yang ditonjolkan adalah vokalnya, sedangkan instrumennya berfungsi untuk pengiring dan memeriahkan, sehingga pertunjukan yang disajikan bertambah sempurna. Untuk mengendalikan keseimbangan dalam menampilkan aransemen yang telah disusun diperlukan adanya seorang pemimpin yaitu seorang dirigen atau kondakter. (http;//mgmpseni.wordpress.com/materi-belajar/seni-musik/semester-1/kelas-

vii/aransemen-musik/)

Dalam aransemen terdapat banyak jenisnya, salah satunya yaitu aransemen campuran, untuk memaknai secara sederhana tentang aransemen ini adalah dengan mendegarkan lagu yang sudah diaransemen, biasanya dalam aransemen campuran terdapat suara vokal dan suara alat musik. Dalam aransemen tersebut suara vokal lebih menonjol sedangkan aransemen instrument berfungsi sebagai pengiring dari aransemen tersebut.

\subsection{Komponen-Komponen Aransemen}

\subsubsection{Irama}

Irama adalah urutan rangkaian gerak yang menjadi unsur dalam sebuah musik (Jamalus 1998:7). Irama dalam musik terbentuk oleh bunyi dan diam dengan bermacam-macam lama waktu atau panjang pendeknya, membentuk pola irama, bergerak menurut pulsa dalam ayunan irama. Irama dapat dirasakan dan 
didengar (Soeharto 1992:51). Irama berhubungan dengan panjang pendeknya not dan berat ringannya tekanan atau aksen pada not. Namun demikian, oleh teraturnya gerak maka irama tetap dapat dirasakan meskipun melodi diam. Dan keteraturan gerak ini menyebabkan lagu lebih indah didengar dan dirasakan (Jamalus 1998:56)

\subsubsection{Melodi}

Melodi adalah rangkaian dari beberapa nada atau sejumlah nada yang berbunyi atau dibunyikan secara berurutan (Soeharto 1992 : 1), menurut ( Jamalus 1998 : 16 ) melodi adalah susunan rangkaian nada (bunyi dengan getaran teratur) terdengar berurutan serta berirama dan mengungkapkan suatu pikiran atau perasaan. Dari pengertian-pengertian tersebut, dapat dikatakan bahwa melodi merupakan rangkaian nada-nada yang memiliki ketetarturan, yang disusun secara ritmis yang mengungkapkan sesuatu perasaan dan pikiran.

\subsubsection{Harmoni}

Harmoni atau paduan nada adalah bunyi gabungan dua nada atau lebih, yang memiliki perbedaan tinggi rendahnya dan dibunyikan secara serentak. Dasar dari nada tersebut adalah trinada (Jamalus 1998:30). Paduan nada tersebut merupakan gabungan tiga nada yang terdiri atas satuan nada dasar akord, nada terts dan nada kwintnya. Harmoni adalah selaras atau sepadan, bunyi serentak menurut harmoni, yaitu pengetahuan tentang hubungan nada-nada dalam akor, serta hubungan antara masing-masing akor. Pendapat diatas dapat ditangkap secara sederhana yaitu bahwa harmoni adalah paduan nada-nada yang apabila dibunyikan secara bersama-sama akan menghasilkan keselarasan bunyi. 


\subsection{Manajemen}

\subsubsection{Pengertian Manajemen}

Ilmu teknik manajemen didasari oleh konsep bahan tugas manajer ( orang yang melaksanakan manajemen) yaitu untuk merancang dan mendukung pelaksanaan perkerjaan individu pada satu kelompok, dalam rangka mencapai tujuan yang telah ditetapkan sebelumnya, (Herdian Adi Prasetia 2010 : 8). Dalam manajemen seorang pemimpin diperlukan untuk merancang dan mendukung kegiatan yang direncanakan demi mencapai tujuan kelompok yang sebelumnya sudah di musyawarahkan.

Manajemen berasal dari kata to manage (bahasa Inggris), yang memiliki arti sebagai berikut: mengurus, mengatur, mengelola (Gomes, 2001 : 1). Pendapat (Jazuli 2014 : 4) kata manajemen (bahasa Inggris) adalah management berasal dari kata to manage yang artinya mengatur, mengelola, dan mengendalikan sesuatu. Manajemen menurut Mary Parker Follet (dalam Erni Tisnawati Sule dan Kurniawan Saefullah, $2005: 5)$ memaparkan sebagai berikut "Management is the art off getting things done trough people" manajemen adalah seni dalam menyelesaikan sesuatu melalui orang lain. Dapat ditarik kesimpulan dari dua teori di atas bahwa untuk menyelesaikan suatu pekerjaan atau tujuan oranganisasi dibutuhkan seorang manajer (leader) melalui orang lain untuk melaksanakan pembagian tugas atau pekerjaan demi terwujudnya tujuan bersama atau dapat dikatakan juga dengan demikian manajemen merupakan kegiatan pengaturan proses sumber daya manusia dan sumber-sumber lainnya secara efektif dan efisien untuk mencapai tujuan melalui orang lain. 
Lebih dalam tentang manajemen dijelaskan dengan demikian, bahwa manajemen merupakan sebuah proses perencanaann, pengorganisasian, pengoordinasian, dan pengontrolan sumber daya untuk mencapai sasaran efektif dan efisien, Ricky W. Griffin (dalam Subeki Ridhotullah, M.M. dan Mohamad Jauhar, S.Pd. 2015:1). Definisi yang lebih sepesifik akan pemahaman tantang fungsi manajemen menurut George R. Terry (dalam Jazuli, 2014 : 12) merumuskan sebagai berikut : (1) Perencanaann atau planning, (2) Pengorganisasian atau organizing, (3) Penggerakan atau actuating, Pengawasan dan evaluasi atau controlling.

Manajemen seni pertunjukan merupakan bagian-bagian dari sebuah seni, dalam kehidupan sehari-hari produksi akan dikenal melalui manajemenya, di dalam konteks seni pertunjukan, kata "produksi" sering dikenali dengan makna penggarapan atau proses garap. Mengenai hal tentang manajamen seni pertunjukan adalah bagian dari seni dalam (Jazuli, 2014:11) menerangkan bahwa di Amerika tempat berkembangnya seni pertunjukan, menurut Charles dan Stepanie Reinhart, manajemen produksi pertunjukan mulai dipelajari di beberapa universitas amerika tahun 1970-an. Di Indonesia, meskipun istilah manajemen seni pertunjukan dipopulerkan sekitar tahun 1980-an tetapi kegiatan manajerial pertunjukan boleh jadi telah lama dilakukan. Barangkali saja orentasi manajemen bukan semata-mata untuk memperoleh keuntungan ekonomi, melainkan demi prestis.

Seni pertunjukan merupakan sebuah ungkapan budaya, wahana untuk menyampaikan nilai-nilai budaya dan perwujudan norma-norma estetis yang 
berkembang sesuai dengan zaman, dan wilayah dimana bentuk seni pertunjukan itu tumbuh dan berkembang (Bagus Susetyo, 2007:1). Dalam memahami teori tersebut dapat dipahami secara sederhana sebagai berikut, seni pertunjukan adalah hasil dari sebuah budaya yang ditunjukan atau diperlihatkan sebagai sebuah penyampain makna yang mengandung nilai-nilai positif serta perwujudan dari sebuah keindahan, sesuai dengan zaman dan tempat seni tersebut tumbuh dan berkembang. Seni pertunjukan yang ada di Indonesia akan semakin maju apabila memfokuskan pada organisasinya. Mengenai hal tersebut dikemukakan oleh (Hartono,2001 : 49) organisasi sangat berperan untuk tumbuh suburnya sebuah kesenian. Untuk masa depan dalam kesenian diharapkan sebuah kualitas baik itu dari segi pelaku dan produk yang dihasilkan, akhirnya akan selalu berusaha untuk meningkatkan mutu dan memberi kepuasan kepada pelanggan. Di dalam sebuah seni pertunjukan hal terpenting adalah pelanggan atau penikmat sebagai aspek dalam kemajuan.

\subsection{Fungsi Dasar Manajemen}

Di dalam manajemen terdapat 4 fungsi dasar yang dirumuskan oleh George R. Terry (dalam Jazuli 2014 : 12), fungsi dasar tersebut antara lain sebagai berikut:

\subsubsection{Perencanaan ( planning)}

Perencaan atau planing merupakan proses yang menyangkut upaya yang dilakukan untuk mengantisipasi kecenderungan di masa yang akan datang dan penentuan strategi dan taktik yang tepat untuk mewujudkan target dan tujuan organisasi. Menurut Jazuli ( 2014 : 12 ) mengatakan bahwa perencanaan adalah 
serangkaian tindakan yang dilakukan sebelum dimulai hingga proses usaha yang masih berlangsung. Dalam perencanaan terdapat beberpa alternatif untuk mewujudkan hal tersebut diantaranya sebagai berikut; (1) program, yaitu acara kerja yang dicanangkan harus rasional, matang, jangka waktu, dan lain sebagainya, (2) Kompetensi, yaitu tingkatan wewenang dan tanggung jawab perlu pembagian yang jelas, (3) Kerja sama, yaitu struktur organisasi cukup mudah dilaksanakan sehingga prosedur kerja dan interaksi antara para personel harus rasional.

\subsubsection{Pengorganisasian (organizing)}

Pengorganisasian diartikan sebagai keseluruhan proses pengelompokan orang-orang, alat, tugas, dan tanggung jawab (wewenang) sedemikian rupa sehingga tercipta suatu organisasi yang dapat digerakan menjadi satu kesatuan kerja sama untuk mencapai tujuan (Jazuli, 2014:13). Prinsip dari pengoroganisasian adalah pembagian tugas atau kerja sesuai dengan kapasitas atau kemampuan dari individu.

\subsubsection{Penggerakan (actuating)}

Di dalam pelaksanaan unsur manajemen terdapat kaitan yang sangat manuasia sebagai pelaku. Realita yang ada di dalam pelaksanaan unsur manajemen tersebut tidaklah lepas dari hambatan, hambatan yang terjadi biasanya dikarenakan oleh manusia, hal tersebut disebabkan manusia memiliki tingkat emosi yang berbeda, memiliki sifat yang berbeda, dan memiliki perilaku yang berbeda pula antara satu dengan yag lain. Maka dari itu kegunaan seorang manajer sebagai seorang pemimpin diperlukan untuk membina bawahan dengan baik 
melalui bimbingan dan motivasi yang baik, demi mewujudkan tujuan bersama, supaya dapat tercapai dengan efektif dan efisien.

\subsubsection{Pengawasan (controling)}

Pendapat dari (Subekhi Ridhotullah, M.M. dan Mohamad Jauhar, S.Pd. 2015:19) mengatakan bahwa pengawasan adalah proses pengamatan dari keseluruhan kegiatan organisasi guna lebih menjamin bahwa semua pekerjaan yang sedang dilakukan sesuai dengan rencana yang telah ditentukan. Fungsi dari pengawasan adalah sebagai salah satu cara untuk menjamin bahwa pelaksanaan tugas-tugas atau pembagian pekerjaan berlangsung dengan baik dan sesuai dengan rencana yang telah ditetapkan. Apabila terjadi suatu keganjilan ataupun masalahmasalah dalam pelaksanaan maka akan segera terlihat secara cepat dan dapat segera diperbaiki.

\subsection{Pentingnya Manajemen}

Pada intinya manusia itu tidak bisa melakukan sesuatu yang besar dengan sendiri atau kata lain bahwa manusia mempunyai kemampuan yang terbatas (pengetahuan, fisik, dan waktu) sedangkan pekerjaan atau tanggung jawab mereka tidak terbatas. Dalam rangka memenuhi pekerjaan atau tanggung jawab manusia melalui usaha, menjadikan manusia membagi tugas, pekerjaan dan pemikiran. Melalui pembagian tugas, pemikiran, dan pekerjaan tersusunlah manusia dalam wadah organisasi yang mempunyai ikatan formal, sehingga pekerjaan yang terasa sulit dan berat dapat diselesaikan sesuai dengan tujuan yang ingin dicapai secara efektif dan efesien. Manajemen diperlukan untuk mencapai tujuan yang efektif dan efesien. Efektif adalah selalu menjaga keseimbangan terhadap pelbagai 
perbedaan yang menghambat pencapain tujuan, sedangkan efisien maksudnya adalah cara menyelesaikan suatu pekerjaan secara tepat dan dilakukan dengan benar-benar sehingga pengeluaran biaya lebih kecil dari pada pendapatan, dan waktu kerja lebih dihargai ( Jazuli, $2014: 2$ ).

Menurut Hasibuan (2001 : 3) pada dasarnya manajemen itu penting sebab : (1) Pekerjaan itu berat dan sulit untuk dikerjakan sendiri, sehingga diperlukan pembagian kerja, tugas dan tanggung jawab dalam penyelesainnya, (2) Manajemen yang baik akan meningkatakan daya guna dan hasil guna semua potensi yang dimiliki, (3) Manajemen yang baik akan mengurangi pemborosanpemborosan, (4) Manajemen perlu untuk kemajuan dan pertumbuhan, (5) Manajemen mengakibatkan pencapaian tujuan secara teratur, (6) Manajemen merupakan suatu pedoman pikiran dan tindakan, (7) Manajemen selalu dibutuhkan dalam setiap kerja sama kelompok.

Dari teori Hasibuan diatas dapat diambil arti bahwa manajemen sangatlah penting untuk mengatur semua sendi kegiatan manusia, dalam contoh : sekolah, perusahaan, rumah tanggah, organisasi kemasyarakatan, dan pemerintahan. Melalui manajemen yang baik dan benar maka akan tercipta kerja sama yang baik pula dan mengurangi gesekan-gesekan dalam pembagian kerja sama sehingga tujuan yang telah direncanakan akan tercapai secara optimal serta efisien dan efektif. 


\section{BAGAN FUNGSI DASAR MANAJEMEN}

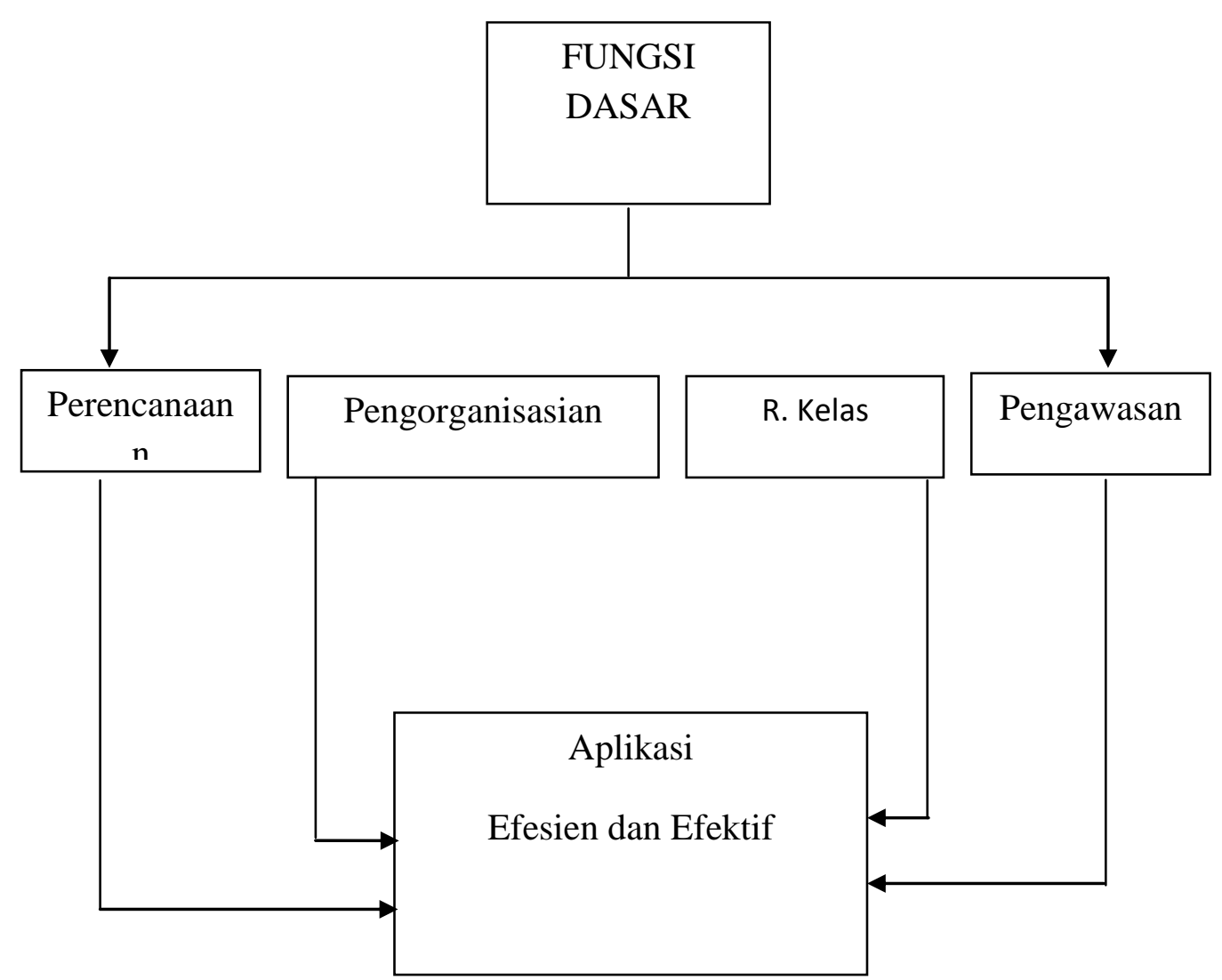

Bagan 1. Bagan Fungsi Dasar Manajemen

( Sumber : Jazuli, 2001 diolah dari Geogre R Terry, 1960 )

\subsection{Faktor-faktor Manajemen}

Manajemen dapat dipahami sebagai sebuah usaha pengelolaan terhadap penggunaan sumber daya atau faktor-faktor produksi secara optimal, atau sebuah proses pengolahan bahan mentah menjadi suatu produk atau suatu jasa yang lebih berdaya guna. Faktor-faktor manajemen tersebut meliputi: bahan (material), 
modal, tenaga kerja, peralatan, dan informasi. Faktor-faktor dalam manajemen (Bastomi 1996: 50) yaitu:

\subsubsection{Faktor Internal}

Faktor internal adalah faktor yang berasal dari dalam lingkup Marching Band Domenico Savio yang menjadi faktor utama, yang menentukan kinerja dari manajemen Marching Band Domenico Savio. Faktor tersebut diantaranya: (1) Man (manusia), manusia di sini adalah orang-orang yang terlibat dalam manajemen Marching Band Domenico Savio secara langsung, diantaranya adalah: anggota, manajer atau ketua, pelatih, dan official. (2) Metode (cara), faktor ini menunjang kualitas dari hasil pertunjukan. Metode meliputi: pembuatan aransemen lagu, dan latihan. Metode yang maksimal akan menentukan hasil pertunjukan dan prestasi.

\subsubsection{Faktor Eksternal}

Faktor eksternal adalah faktor yang berasal dari luar sistem kelompok, dalam hal ini berasal dari luar lingkup Marching Band Domenico Savio, tetapi mempengaruhi kinerja dari manajemen Marching Band Domenico Savio. Faktor eksternal ini antara lain: (1) Money (modal), Faktor ini menjelaskan betapa pentingnya modal. Dalam hal ini uang sebagai awal melakukan kegiatan latihan dan pembuatan aransemen lagu dalam mempersiapkan sebuah perlombaan .Modal atau uang sebagai penunjang utama yang tidak dapat diganti oleh faktor lainnya, (2) Material (alat), Faktor ini sangat menentukan kualitas dari hasil karya musik Marching Band Domenico Savio.

\subsection{Penelitian Yang Relevan}


Penelitian tentang manajemen marching band ini bukan satu-satunya penelitian yang dilakukan oleh penulis. Ada beberapa referensi yang menginspirasi penulis untuk melakukan penelitian ini. Salah satu contohnya penelitian yang mempunyai hubungan yang sama dengan penelitian yang diambil oleh penulis dari beberapa sumber.

Sumber pertama adalah penelitian yang dilakukan oleh Tyas Bayu Setiaji (UNNES 2010), yang berjudul "Manajemen Group Musik Saestu di Semarang”. Penelitian ini bertujuan untuk mendeskripsikan tentang manajemen yang dikelola oleh group band Saestu di Semarang. Penelitian ini merupakan penelitian kualitatif yang disertai dengan analisa manajemen group musik.

Sumber kedua adalah penelitian yang dilakukan oleh Bernard Oliver Andreas Simanjorang, (UNY 2013) dengan judul "Bentuk Aransemen dan Fungsi Musik Kelompok North Sumatra Brass Dalam Tata Ibadah Gereja Huria Kristen Batak Protestan(HKBP) di Yogyakarta". Dalam penelitian tersebut bertujuan untuk mendeskripsikan tentang bentuk aransemen dan fungsi musik pada gereja, penelitian merupakan penelitian kualitatif dengan analisa bentuk aransemen dan fungsi musik.

Sumber ketiga adalah penelitian yang dilakukan oleh Herdiyan Adi Prasetya (UNNES 2010) yang berjudul "Manajemen Produksi Kelompok Musik Shaggydog di Yogyakarta : Kajian Manajemen Produksinya”. Penelitian ini bertujuan untuk mendeskripsikan tentang bagaimana manajemen produksi yang dilakukan oleh group band Shaggydog. Penelitian ini merupakan penelitian kualitatif yang menganalisa manajemen produksi pada group band. 


\subsection{Kerangka Berpikir}

Untuk menunjang perkembangan Marching Band SMP Pangudi Luhur Domenico Savio Semarang, dibutuhkan manajemen atau pengelolaan Marching Band yang baik yaitu Marching Band yang mempunyai tujuan yang jelas dengan beberapa langkah - langkah yang perlu diperhatikan, menurut Jazuli ( 2014 : 1220 ) langkah menajemen tersebut adalah : perencanaann (planning), pengorganisasian (organizing), penggerakan (actuating), pengawasaan (controling). Aransemen yang digunakan saat perlombaan merupakan salah satu faktor yang menunjang dalam meraih sebuah kemenangan.

Maksud dari manajemen Marching Band SMP Pangudi Luhur Domenico Savio Semarang adalah sebuah peroses yang dijalankan oleh Marching Band SMP Pangudi Luhur Domenico Savio Semarang dengan proses perencanaann program, pengoorganisasin, penggerakan dan pengawasan serta usaha-usaha anggota organisasi Marching Band SMP Pangudi Luhur Domenico Savio Semarang supaya tujuan organisasi yang telah direncanakan dapat tercapai dan maksud dari aransemen Marching Band band SMP Pangudi Luhur Domenico Savio adalah mengetahui lagu yang dibawakan saat mengikuti sebuah perlombaan dan mengetahui bagaimana mengelola aransemen yang ada, supaya dapat dimainkan dengan benar.

Dengan kerangka berpikir di bawah, maka penelitian ini diarahkan pada analisis aransemen Marching Band Domenico Savio yang digunakan dalam perlombaan dan pengelolaan manajemen Marching Band Domenico Savio. Dengan pemikiran tersebut, aransemen yang baik diharapkan Marching Band 
Domenico Savio dapat memperoleh prestasi yang gemilang dan Marching Band Domenico Savio dapat bertahan dari persaingan melalui segi musikalitas dari marching band-marching band yang lain. Dengan pemikiran tersebut, pengelolaan yang baik diharapkan Marching Band SMP Pangudi Luhur Domenico Savio Semarang dapat lebih berprestasi lagi dan dapat bertahan seiring perkembangan zaman serta dapat bertahan diantara persaingan Marching Band di tingkat daerah maupun di tingkat nasional.

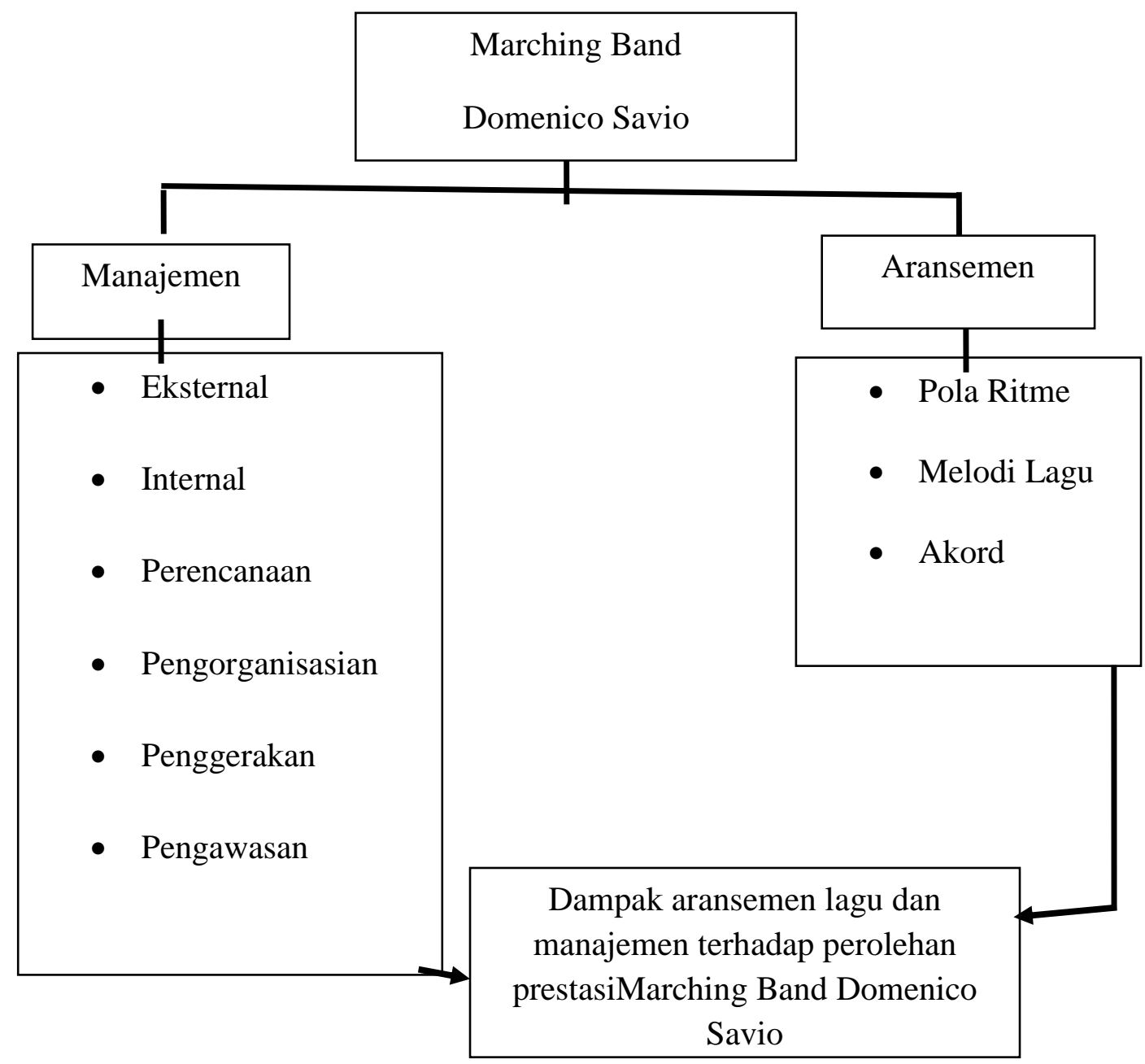

Bagan 2. Kerangka Berpikir 


\section{BAB 3}

\section{METODE PENELITIAN}

\subsection{Metode dan Pendekatan Penelitian}

Dalam penilitian ini menggunakan metode kualitatif, yang memiliki makna sebagai berikut, metode kualitatif adalah permasalahan yang dibahas dalam penelitian tidak berkenaan dengan angka-angka dan penelitian bertujuan untuk menggambarkan sesuatu menguraikan tentang hal-hal yang berhubungan dengan keadaan (Moleong, 2000 : 103). Penelitan menurut Bogdan \& Taylor dalam (Totok Sumaryanto, 2014 : 14) penilitian kualitatif sebagai prosedur penelitian yang menghasilkan data deskriptif berupa kata-kata tertulis atau lisan dari orang-orang dan perilaku yang dapat diamati. Dari teori di atas dapat diambil makna yaitu metode kualitatif merupakan metode yang dilakukan dalam penelitian hasil data yang diperoleh adalah kata-kata atau tulisan untuk menggambarkan suatu objek dengan kenyataan yang ada di lapangan.

Pendekatan yang digunakan oleh peneliti merupakan pendekatan musikologi dan pendekatan manajemen pertunjukan. Pendekatan musikologi digunakan untuk mengkaji tentang aransemen lagu pada Marching Band Domenico Savio Semarang sedangkan pendekatan manajemen pertunjukan digunakan untuk mengkaji manajemen yang diterapkan Marching Band Domenico Savio Semarang.

Pada laporan hasil penelitian berupa rumusan konsep-konsep melalui katakata untuk menggambarkan sesuatu dengan teliti dan rinci. Dalam penelitian ini 
peneliti akan melibatkan diri dengan terjun ke lapangan untuk mengumpulkan data yang sebanyak-banyaknya.

\subsection{Lokasi dan Sasaran Penelitian}

Penelitian ini dilakukan di SMP Pangudi Luhur Domenico Savio Semarang, Jl. Dr Sutomo No. 46 di dearah Tugu Muda Semarang. Sasaran dari penelitian ini sesuai dengan permasalahan yang telah dipaparkan, yaitu Marching Band SMP Pangudi Luhur Domenico Savio Semarang Kajian: Aransemen dan Manajemen.

\subsection{Teknik Pengumpulan Data}

Pengumpulan data merupakan langkah yang sangat penting dalam rangka penelitian, pengumpulan data akan berpengaruh pada langkah-langkah berikutnya. Dalam pengumpulan data merupakan hal yang sangat penting, maka memerlukan metode agar data yang diperoleh merupakan data yang relevan, akurat, dan dapat dipercaya. Proses pengumpulan data, peneliti merupakan instrument yang utama (Moloeng, 2000 : 121). Data yang akan diambil atau akan dikumpulkan tersebut biasanya menggunakan beberapa metode. Metode yang digunakan jelas menentukan hasil yang didapat dan metode yang dipakai juga harus disesuaikan dengan kondisi, sifat, dan karakteristik dari objek yang akan diteliti. Beberapa instrument atau alat pengambil data dijabarkan sebagai berikut :

\subsubsection{Teknik Observasi}

Observasi merupakan suatu kegiatan pengamatan secara langsung, meliputi kegiatan pemusatan perhatian terhadap sesuatu objek dengan menggunakan alat indra ( Arikunto, 1998 : 146 ). Observasi merupakan metode 
pengumpulan data yang menggunakan pengamatan terhadap objek penelitian. Observasi dapat dilakukan secara langsung maupun secara tidak langsung. Observasi langsung adalah mengadakan pengamatan secara langsung (tanpa alat) terhadap gejala-gejala obyek yang akan diselidiki, baik pengamatan itu dilakukan di dalam situasi sebenarnya maupun dilakukan di dalam situasi buatan yang khusus diadakan, sedangkan observasi tidak langsung adalah mengadakan pengamatan terhadap gejala-gejala obyek yang diselidiki dengan perantara sebuah alat. Pelaksanaanya dapat berlangsung di dalam situasi yang sebenarnya maupun di dalam situasi buatan.

Dalam penelitian ini menggunakan jenis observasi langsung, yaitu pengamatan yang dilakukan terhadap obyek di tempat terjadi atau berlangsungnya peristiwa. Peneliti akan terjun langsung di lapangan dan akan mengamati sendiri bagaimana kegiatan Marching Band yang dilakukan, dari bentuk fisik tempat sekolah SMP Pangudi Luhur Domenico Savio Semarang, dimana tempat latihan ekstrakurikuler Marching Band, bagaimana aransemen lagu yang digunakan dalam latihan, bagaimana pengelolaan Marching Band yang dilakukan oleh pihak sekolah, mengamati latihan Marching Band serta agenda rutin mingguan, bulanan, agenda dalam mempersiapkan perlombaan. Teknik observasi tersebut dilaksanakan untuk mengetahui Marching Band SMP Pangudi Luhur Semarang Kajian : Aransemen dan Manajemen 


\subsubsection{Tenik Wawancara}

Teknik wawancara adalah cara mengumpulkan data melalui kontak atau hubungan pribadi antara pengumpulan data dengan sumber data (Margono, 1996: 165). Wawancara merupakan alat pengumpulan informasi dengan cara mengumpulkan sejumlah pertanyaan secara lisan untuk dijawab secara lisan pula. Ciri utama dari wawancara adalah kontak langsung dengan tatap muka antara pencari informasi (interviewer) dan sumber informasi (interview).

Untuk menciptakan kerjasama dan membina kerjasama yang baik antara pencari informasi dan sumber informasi, maka dapat dilakukan hal-hal berikut:

3.3.2.1 Partisipasi, yaitu penerimaan dan keikutsertaan intrviewer dalam kegiatan iterviewe sehingga tanya jawab berlangsung dengan suasana yang nyaman.

3.3.2.2 Identifikasi, yaitu perkenalan dan pendekatan dari intrviewer sehingga intrviewer dirasakan sebagai teman atau orang seperjuangan.

3.3.2.3 Persuasi, yaitu sikap sopan dan ramah dalam bertanya. Menumbuhkan keyakinan pada diri intrviewer bahwa informasi yang akan disampaikan sangat penting sehingga harus dikemukakan secara lengkap dan sejujur-jujurnya.

Teknik wawancara yang akan dilakukan dalam penelitian ini adalah dengan cara tatap muka one-to-one yang terdiri dari pertanyaan dan jawaban, yang dilaksanakan langsung kepada pembina untuk mencari informasi tentang sekolah dan pengelolaan marching band, alumni untuk mencari infomasi tentang keikutsertaan dan kontribusi marching band, pelatih untuk mencari tentang aransemen lagu dan manajerial yang diterapkan dalam melatih marching band. 


\subsubsection{Teknik Dokumentasi}

Teknik dokumentasi adalah teknik pengumpulan data mengenai hal-hal yang variabel yang berupa catatan, transkip, buku, surat kabar, majalah, notulen, agenda, dan sebagainya (Arikunto 1998: 236). Dalam teknik ini yang dicari berupa data dan jumlah besarnya media penunjang aransemen dan manajemen, serta foto-foto yang berhubungan dengan pelaksanaan kegiatan Marching Band dalam manajemen dan aransemen di SMP Pangudi Luhur Semarang serta dalam teknik ini peneliti akan mencari data tentang aransemen lagu untuk dianalisis dan dikaji. Teknik ini dilakukan untuk memperoleh data sekunder guna melengkapi data yang belum diperoleh melalui teknik observasi dan teknik wawancara. Kemudian hasil dokumentasi ini disusun sedemikian rupa menjadi data sekunder yang digunakan untuk melengkapi data primer hasil dari pengamatan dan wawancara. Data primer adalah data yang diperoleh langsung dari responden atau sumber, melalui teknik wawancara, sedangkan data sekunder adalah data yang digunakan untuk melengkapi atau membantu menyelesaikan data primer yang berupa arsip-arsip ataupun dokumentasi.

\subsection{Teknik Analisis Data}

Miles \& Huberman (dalam Totok Sumaryanto, 2014:44) mengungkapkan bahwa teknik data kualitatif memaparkan data yang muncul dari penelitian kualitatif berwujud kata-kata dan bukan rangkaian angka. Data itu mungkin telah dikumpulkan dalam aneka macam cara (observasi, wawancara, dan dokumen) dan yang diperoses sebelum siap digunakan (melalui pencatatan, pengetikan, 
penyuntingan), akan tetapi analisisnya tetap menggunakan kata-kata yang disusun ke dalam teks yang diperluas. Analisa tersebut dibagi kedalam tiga tahap, yaitu :

\subsubsection{Reduksi Data}

Reduksi data diartikan sebagai pemilahan, pemusatan perhatian pada penyederhanaan, pengabstrakan, data transformasi data "kasar" yang muncul dari catatan-catatan yang muncul di lapangan. Reduksi data berlangsung terusmenerus selama proyek yang berorientasi kualitatif berlangsung. Sebenarnya bahkan sebelum data benar-benar terkumpul, antisipasi adanya reduksi data sudah tampak waktu penelitian memutuskan kerangka konseptual wilayah penelitian, permasalah penelitian, dan pendekatan pengumpulan data yang dipilihnya. Selama pengumpulan data berlangsung, terjadilah tahapan reduksi data selanjutnya (membuat ringkasan, kode, dan menulis memo)

Reduksi data merupakan suatu bentuk analisis yang, menggolongkan, mengarahkan, membuat yang tidak perlu, dan mengorganisasi data dengan cara sedemikian rupa sehingga kesimpulan-kesimpulan final dapat ditarik dan diverivikasi.

\subsubsection{Penyajian Data}

Penyajian data adalah sebagai sekumpulan informasi yang tersusun dan memberi kemungkinan adanya penarikan kesimpulan dan pengambilan tindakan.

\subsubsection{Menarik Kesimpulan/Verivikasi}

Kegiatan analisa ini amat penting, sabab dari permulaan pengumpuan data, seorang penganalisis kualitatif mulai mencari arti benda-benda mencatat 
keteraturan, pola-pola penjelasan, konfirgurasi-konfigirasi yang mungkin, alur sebab akibat serta perposisi.

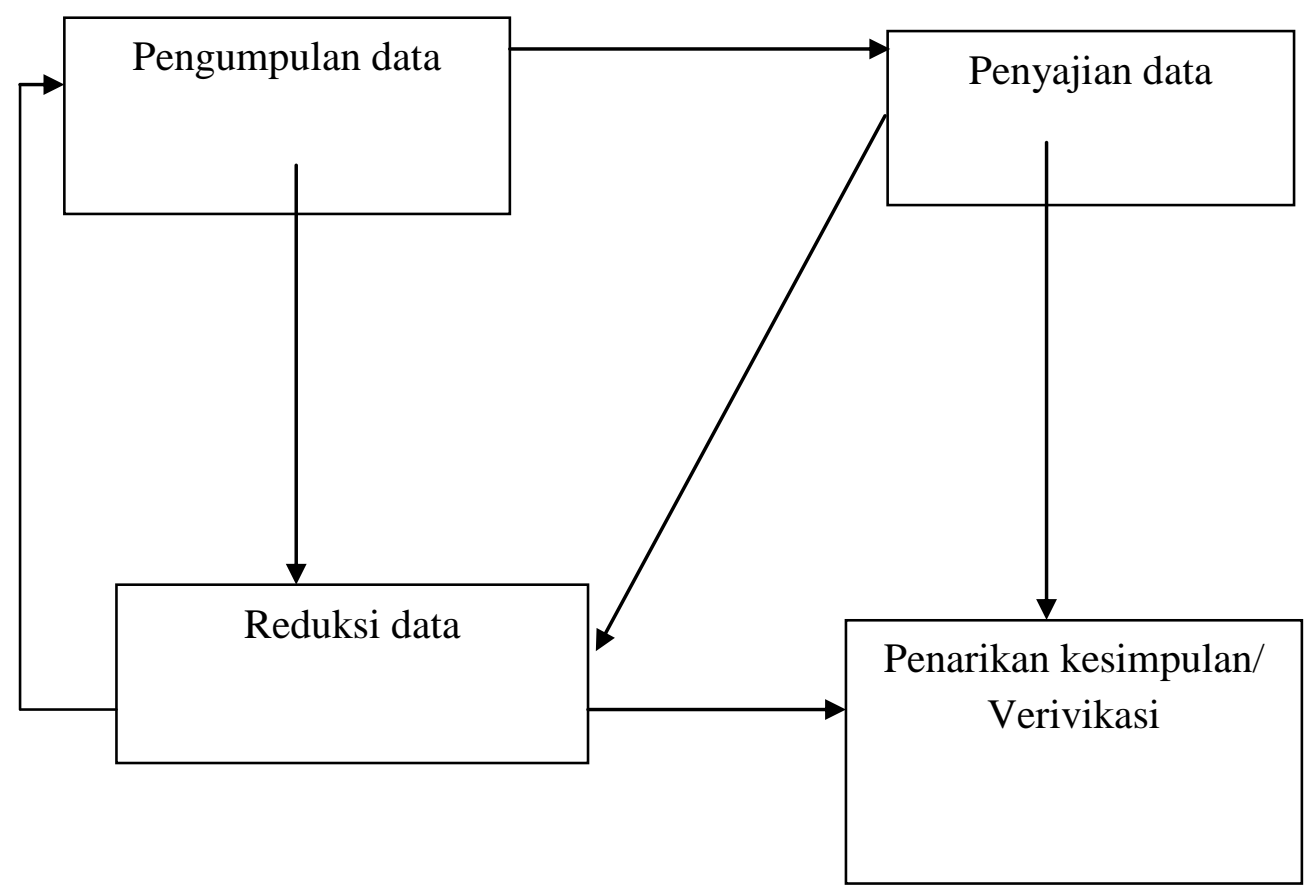

Bagan 3. Metode Penelitian

Sumber: Analisis Data Kualitatif ( Miles dan Huberman 1992 : 25-21 ) 


\section{BAB 4}

\section{HASIL PENELITIAN DAN PEMBAHASAN}

\subsection{Gambaran Umum Lokasi Penelitian}

\subsubsection{Lokasi SMP Pangudi Luhur Domenico Savio Semarang}

SMP Pangudi Luhur Domenico Savio Semarang merupakan sekolah swasta atau dapat dikatakan hak milik sekolah tersebut adalah atas nama oraganisasi selain dari pemerintah. Sekolah tersebut dinaungi oleh Yayasan Pangudi Luhur, yayasan tersebut merupakan yayasan Katholik yang bergerak dibidang pendidikan, yayasan tersebut mempunyai beberapa sekolah di Jawa Tengah, seperti di Semarang yaitu SMP Domenico Savio. Nama Domenico Savio yang dijadikan nama dari SMP tersebut merupakan nama yang diambil dari seorang st ( Santo atau orang kudus).

Letak sekolah tersebut sangat strategis berada di tengah kota Semarang, dapat dilalui dari berbagai macam arah, dengan berbagai angkutan dari mulai sepeda hingga angkutan kota. Sekolah tersebut beralamatkan di Jalan Dr.Sutomo No.6 Semarang Jawa Tengah, sekolah tersebut berdekatan dengan Tugu Muda di kota Semarang. Mudah untuk dilalui angkutan kota trans Semarang dari pukul 06.00 WIB sampai pukul 18.00, sehingga para siswa-siswa SMP Domenico Savio Semarang tidak akan mengalami kesulitan untuk menuju sekolah.

Batasan-batasan wilayah dari SMP Pangudi Luhur Domenico Savio Semarang tersebut adalah sebagai berikut, sebelah utara berbatasan dengan Gereja Katedral Semarang dan Jl. Pandanaran sedangkan pada sebelah selatan berbatasan 
dengan Jl. Soetomo dan kompleks penjual bunga, pada sebelah barat berbatasan dengan Jl. Soetomo dan Museum Perjuangan Mandala Bhakti, pada sebelah timur berbatasan dengan J1. Randu Sari Sapean.

Visi yang diusung oleh SMP Pangudi Luhur Domenico Savio Semarang adalah sebagai berikut; Terwujudnya nilai-nilai kristiani yang berpusat pada Yesus Kristus dengan kerja keras, disiplin, rela berkorban, dan sikap sederhana. Sedangkan misi yang diusung oleh SMP Pangdi Luhur Domenico Savio Semarang adalah sebagai berikut; (1) Mewujudkan nilai-nilai kasih Allah, (2) Menciptakan kejujuran, persaudaraan sejati, dan kedamain, (3) Mewujudkan senamgat kerja dan kreatif dengan pantang menyerah yang disenamgati jiwa perubahan, (4) Membangun kedisiplinan dengan menaati tata tertib dan berusaha tetap setia, (5) Menumbuhkan semangat rela berkorban dalam kehidupan berbangsa, bernegara, dan menggereja dengan saling menghormati dan memberi perhatian kepada yang membutuhkan, (6) Menumbuh kembangan sikap hidup sederhana dalam gaya hidup dan pola pikir. Filosofi dari SMP Pangudi Luhur Domenico Savio Semarang tersebut adalah "Lebih baik mati dari pada berbuat dosa".

SMP Pangudi Luhur Domenico Savio Semarang merupakan sekolah swasta yang memiliki prestasi gemilang, ini dapat dilihat dari penunjukan oleh pihak Departemen Pendidikan Jawa Tengah untuk menyelenggarakan dua program pendidikan bagi sekolah tersebut, program tersebut adalah program reguler dengan waktu tiga tahun dan program percepatan atau akselerasi dengan waktu dua tahun 
dan jumlah siswa yang dapat mengikuti program percepatan tersebut adalah dua puluh siswa (observasi, April 2016).

Sekolah ini memiliki banyak ruangan yang dijadikan kelas dan tempat untuk menunjang mata pelajaran yang ada, semua bangunan dari sekolah tersebut merupakan bangunan yang memiliki gaya arsitektur Belanda, seluruh ruang kelas dan ruang guru sudah menggunakan fasilitas yang sangat baik, didalam semua ruang kelas sudah tersedia LCD proyektor untuk menunjang pembelajaran yang efektif dan semua ruang kelas sudah memakai pendingin ruang atau AC agar siswa merasa nyaman saat belajar.

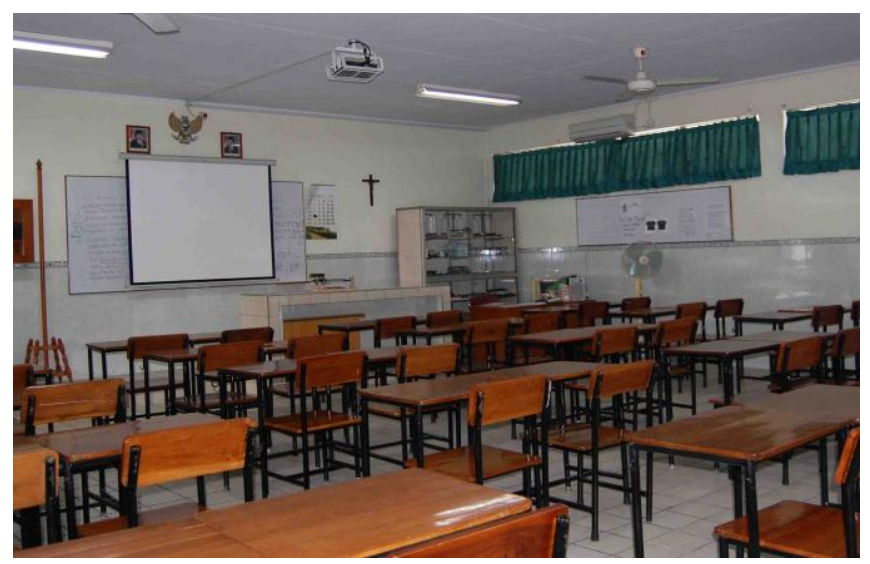

Gambar 1. Ruang Kelas SMP Pangudi Luhur Domenico Savio Semarang ( Sumber : Wibawa, 2016 )

Gambar di atas merupakan contoh dari salah satu ruang kelas yang dimiliki oleh SMP Pangudi Luhur Domenico Savio Semarang. Ruangan tersebut sangatlah baik kondisinya, ruangan tersebut juga memiliki fasilitas yang dapat dikatakan cukup memadahi, fasilitas tersebut seperti LCD proyektor untuk menunjang sarana belajar 
dan mengajar, AC yang digunakan untuk memberikan kenyamanan bagi siswa dalam menimba ilmu di sekolah.

Dalam perkembangannya, SMP Domenico Savio Semarang memiliki banyak kegiatan yang dikhusukan bagi siswa-siswi di sekolah tersebut. Kegiatan yang berfungsi sebagai sarana untuk mengembangkan potensi dan bakat siswa, kegiatan tersebut adalah kegiatan ekstrakurikuler yang dilakukan setelah jam sekolah berkahir, kegiatan eksrtakurikuler didalamnya terbagi menjadi dua, yang pertama ada kegiatan eksrtakurikuler akademik dan ekstrakurikuler non akademik.

Tabel 1. Kegiatan eksrtakurikuler di SMP Pangudi Luhur Domenico Savio

\begin{tabular}{|l|l|l|}
\hline No. & \multicolumn{1}{|c|}{ Nama Kegiatan Eksrtakurikuler } & \multicolumn{1}{|c|}{ Keterangan } \\
\hline 2. & Basket & Non Akademik \\
3. & Voli & Non Akademik \\
4. & Paduan Suara & Non Akademik \\
5. & Marching Band & Non Akademik \\
6. & Band & Non Akademik \\
7. & Modern Dance & Non Akademik \\
8. & Majalah Dinding & Non Akademik \\
9. & Fotografi & Non Akademik \\
10. & Komputer & Non Akademik \\
11. & Pramuka & Non Akademik \\
\hline
\end{tabular}




\begin{tabular}{|l|l|l|}
\hline 13. & PMR (Palang Merah Remaja) & Non Akademik \\
14. & Karya Ilmiah Remaja (KIR) & Non Akademik \\
15 & Olimpiade Matematika & Akademik \\
16. & Olimpiade Fisika & Akademik \\
17. & Bahasa Inggris & Akademik \\
18. & Olimpiade Biologi & Akademik \\
19. & Melukis & Non Akdemik \\
20. & Karate & Non Akademik \\
\hline
\end{tabular}

(Sumber : SMP Pangudi Luhur Domenico Savio Semarang, 2016)

\subsubsection{Denah Penelitian}

Marching Band Domenico Savio Semarang merupakan kegiatan ekstakurikuler yang pengelolaannya dipegang oleh SMP Pangudi Luhur, letak lokasi penelitian ini adalah di daerah kota Semarang, berdekatan dengan Tugu Muda dan kompleks Gereja Katerdral Semaranng, berada di jl.Sutomo no.6.

\begin{tabular}{|c|}
\hline $\begin{array}{c}\text { Tempat } \\
\text { Penyimpanan } \\
\text { Alat }\end{array}$ \\
\cline { 1 - 1 } Kantin \\
\hline \hline Perpustakaan \\
\hline \hline R. Bruder \\
\hline \hline R. Kelas
\end{tabular}

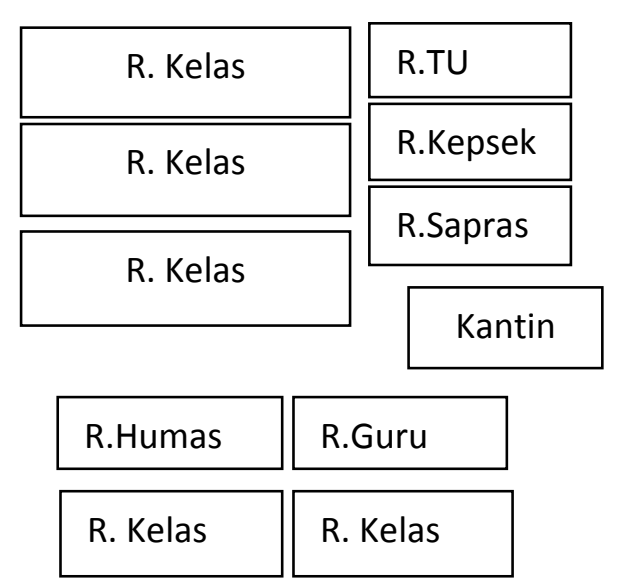

Gambar 5. (Denah SMP Domenico Savio Semarang)

(Sumber : SMP Pangudi Luhur Domenico Savio Semarang, 2016) 
Berdasarkan hasil dari observasi, wawancara, dan analisis data secara kualitatif, peneliti dapat memaparkan hasil penelitian sebagai berikut: gambaran umum Marching Band Domenico Savio Semarang, aransemen lagu yang digunakan Marching Band Domenico Savio Semarang, manajemen yang diterapkan dalam mengelola Marching Band Domenico Savio Semarang.

\subsubsection{Gambaran Umum Marching Band Domenico Savio Semarang}

Marching band adalah salah satu seni pertunjukan yang dapat dinikmati oleh masyarakat umum dan kalangan seniman. Marching band juga merupakan salah satu seni yang didalamnya terdapat unsur olahraga, dimana dalam setiap penampilannya membutuhkan kekompakan, dalam permainan marching band mengharuskan para anggotanya dapat kompak dan memiliki disiplin yang tinggi, sebab permainan marching band merupakan perpaduan antara bermain musik dan gerakan yang telah diatur selama lagu berlangsung, kegiatan tersebut banyak mengandung nilai positif, dalam segi pembinaan kepribadian, yaitu rasa kebersamaan. Uraian diatas dapat diambil sebuah pemahaman bahwa kegiatan marching band memiiki kegiatan nilai positif bagi siswa di sekolah, selain melatih musik, terdapat juga faktor olahraga dan disiplin.

Sebagaimana penjelasan di atas tentang Marching Band Domenico Savio merupakan salah stau marching band yang berlokasi di kota Semarang, yaitu di daerah Tugu Muda Semarang. Marching Band Domenico Savio adalah salah satu kegiatan sekolah yang merupakan ekstrakurikuler pilihan bagi siswa di SMP Pangudi Luhur Domenico Savio Semarang (observasi, Maret 2016). 


\subsubsection{Sejarah Singkat Marching Band Domenico Savio Semarang}

Menurut ibu Maria Yosefa Mariatmi selaku pembina Marching Band Domenico Savio Semarang, mengatakan bahwa Marching Band Domenico Savio Semarang merupakan salah satu kegiatan eksrtakurikuler sekolah di SMP Pangudi Luhur Domenico Savio Semarang. Marching band tersebut sudah berdiri sejak lama yaitu pada tahun 1984 ditahun tersebut yang pertama kali terbentuk adalah Drum Band setelah dua tahun berikutnya tepatnya ditahun 1986 baru terbentuk Marching Band. Marching band Domenico Savio pada saat itu merupakan marching band yang cukup kuat dalam arti bahwa marching band tersebut memiliki nilai yang lebih dengan prestasi sebagai berikut: prestasi yang diraih oleh Marching Band Domenico Savio, yaitu pernah mengikuti kejuaraan Grand Prix Marching Band (GPMB) pada tahun 1996 sebagai finalis di kejuaraan tersebut.

Pada tahun 1998 Marching Band Domenico Savio membuat konser yang bertajuk "Cinta" konser tersebut diadakan sebagai salam perpisahan, hal tersebut merupakan hal yang terkahir bagi Marching Band Domenico Savio sebab setelah itu Marching Band Domenico Savio tidak aktif lagi, dikarenakan minat peserta yang menurun dan kurangnya pengelolaan oleh pihak sekolah. Setelah delapan belas tahun vakum dari kegiatan ekstrakurikuler dan perlombaan-perlombaan, hal ini mengusik hati para alumni yang dahulu pernah mengikuti marching band, mereka berinisiatif untuk mengaktifkan kembali Marching Band Domenico Savio, melalui pembina mereka menyampaikan gagasan mereka dan sekolahpun menyetujui untuk mengkatifkan kembali kegiatan ektrakurikuler marching band, dibantu oleh para 
alumni dalam segi pengelolaan, Marching Band Domenico Savio aktif kembali dan menorehkan kembali prestasi yang membanggakan dan menjadi suatu kebanggaan (wawancara, Maret 2016).

\subsubsection{Struktur pemain dan peralatan yang digunakan Marching Band}

\section{Domenico Savio Semarang}

Marching band merupakan musik yang dimainkan oleh kelompok secara bersama-sama, kelompok pemain atau pada umumnya sering disebut dengan devisi, terbagi atas tiga bagian. Pada devisi pertama ada brass devisi tersebut terdiri dari alat tiup seperti; trumpet, mellophone, baritone, dan tuba sedangkan pada bagian berikutnya adalah devisi perkusi, devisi tersebut merupakan devisi alat musik yang dimainkan dengan cara dipukul seperti: snare drum, bass drum, quartom, cymbals, bells, xylophone, dan vibraphone. Pada devisi berikutnya ada devisi colour guard devisi ini terdiri dari para pemain bendera. Marching Domenico Savio juga memiliki pemain dan peralatan marching band pada umumnya, berikut ini adalah nama para pemain dan alat yang dimainkan.

Tabel 2. Struktur Pemain Marching Band Domenico Savio

\begin{tabular}{|c|c|c|}
\hline NO. & Peralatan yang digunakan & Pemain \\
\hline 1. & Trumpet & $\begin{array}{l}20 \text { pemain ( Ign. Ali Alamsyah, Josef } \\
\text { Fabian, Robertus Nendy, Samuel Cahyo, } \\
\text { Rachel Dina, Gabriel Nesta P, Felisitas S } \\
\text { Nathania, Sandra Putri Arintoro, Audrey } \\
\text { Febianti, Vania, Aji Wijaya, Josphina Priska } \\
\text { M, Gregorius David Wibianto, Crhistphorus }\end{array}$ \\
\hline
\end{tabular}




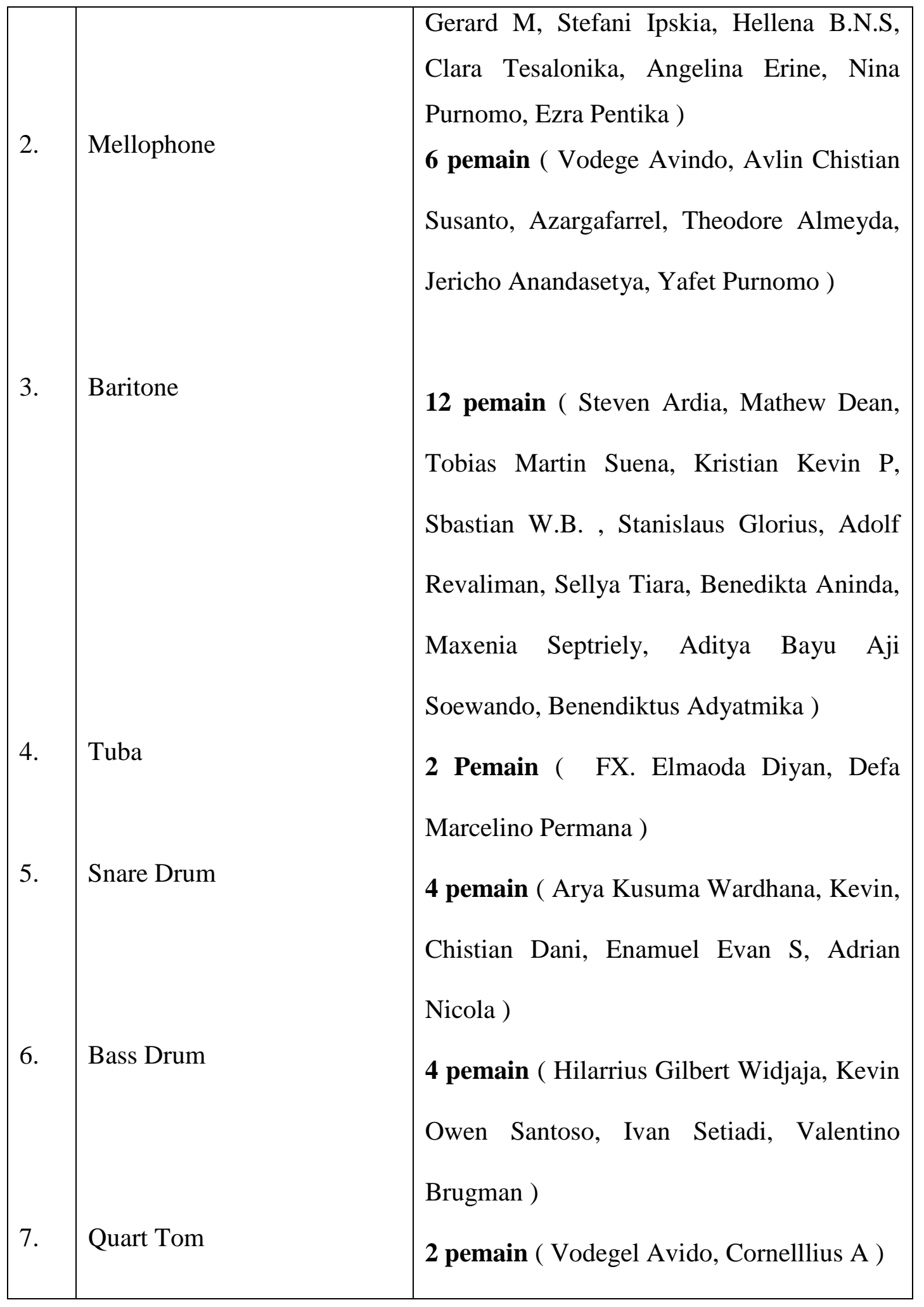




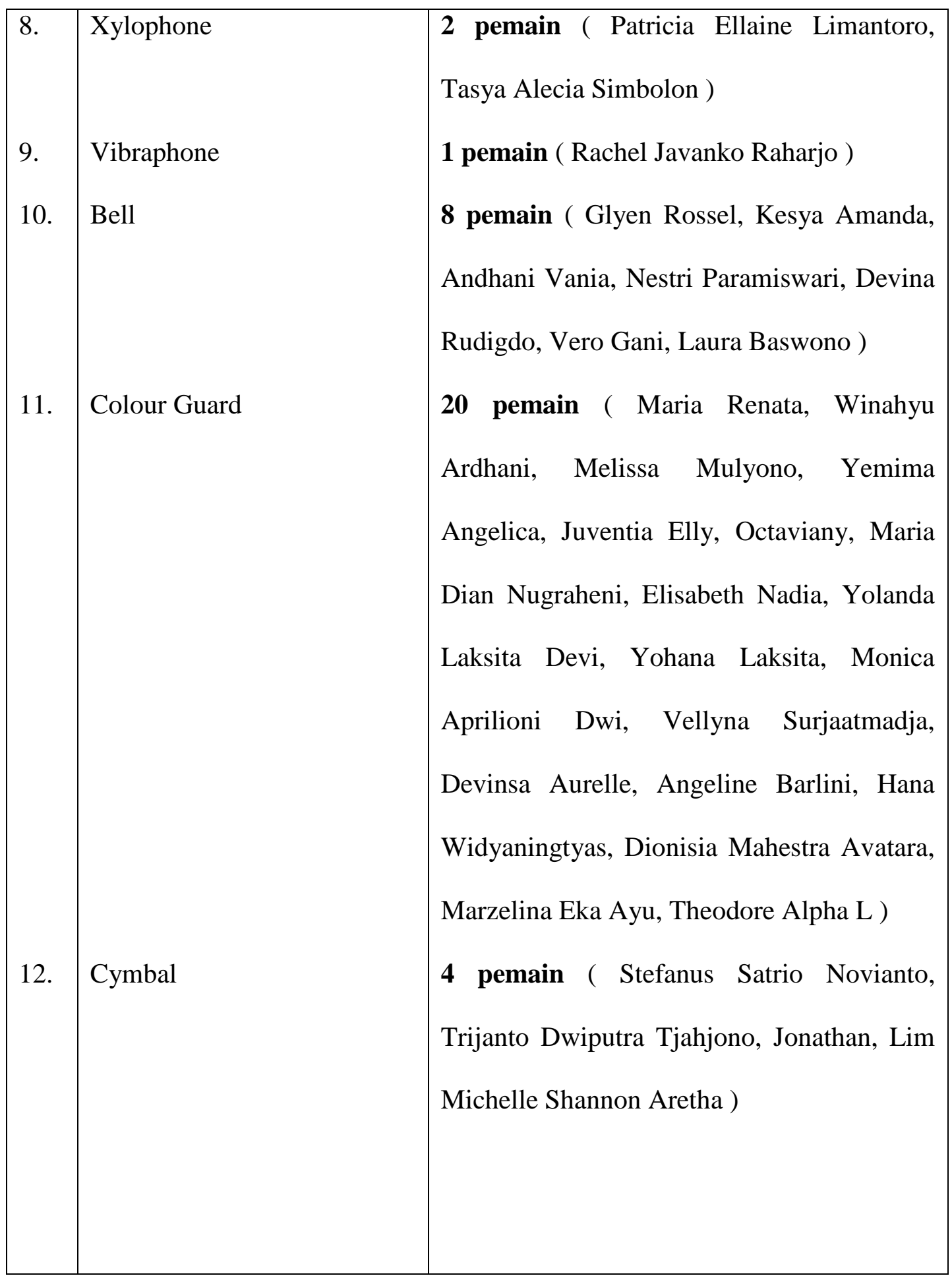

( Sumber : Suroso, 2016) 


\subsection{Aransemen Marching Band Domenico Savio Pada Lagu "Untukku"}

Dalam sebuah pertunjukan marching band, aransemen lagu merupakan salah satu pendukung yang penting dalam sebuah pertunjukan dan peraihan gelar lomba. Menurut Sugeng Basuki, B.A. dkk (1980:89) aransemen berarti pembuatan iringan atau nyanyian dengan mengatur atau mengubah tinggi nada pada bagian motifmotifnya. Dapat dipahami secara sederhana bahwa aransemen merupakan suatu gubahan lagu yang ditulis ulang dengan menambahi melodi-melodi baru dan ornamen-ornamen musik tanpa meninggalkan ciri khas dari lagu tersebut. Biasanya lagu akan diaransemen menyesuaikan dengan tema apa yang akan diangkat dalam perlombaan yang nantinya berbentuk sebuah alur cerita.

Contoh lagu yang diambil oleh peneliti adalah lagu "Untukku" lagu yang dipopulerkan oleh penyanyi legendaris Indonesia yaitu Chrisye, lagu tersebut adalah lagu jenis pop. Dalam pembahasan ini peneliti akan membahas tentang melodi lagu tersebut dalam aransemen, pola ritme, dan akor yang digunakan diaransemen oleh Marching Band Domenico Savio dalam mengikuti perlombaan dikejuaraan Hamengkubuwono CUP, Grand Prix Junior Band, dan Jateng Open. 


\subsubsection{Pola Ritme}

Ritme merupakan gerak teratur karena munculnya aksen secara tetap, pola ritme adalah salah satu aspek dari struktur dasar musik yang meliputi antara lain batteri rhytmic, tone colour, accent (Agus Salim 2010 : 1) dapat dikatakan bahwa ritme adalah gerakan yang teratur dan terdapat aksen di dalamnya yang berhubungan erat dengan waktu dan dalam permainan musik pada umumnya yang memainkan ritme adalah alat musik yang tidak bernada, dan biasanya dimainkan dengan cara dipukul

Marching band sendiri yang merupakan perpaduan dari alat perkusi dan alat tiup yang berpadu menjadi satu kesatuan, dalam marching band alat musik yang banyak memainkan sebuah pola ritme adalah alat perkusi, alat musik perkusi merupakan alat musik yang cara bermainnya dengan dipukul, pada umumnya di dalam marching band alat perkusi tersebut terbagi menjadi empat yaitu: snare drum, quartom, bass drum, snare tenor, timpani, quintom dan cymbal.

Dalam aransemen lagu "Untukku” yang dimainkan oleh Marching Band Domenico Savio Semarang pola ritme dimainkan oleh snare drum, bass drum, quartom, dan cymbals, dalam pembahasan ini peneliti akan menjelaskan tentang pola ritme dari beberapa alat perkusi yang ada pada aransemen lagu "Untukku" yang dimainkan oleh Marching Band Domenico Savio Semarang dalam perlombaan Hamengkubuwono Cup 2015 


\subsubsection{Snare Drum}

Snare Drum
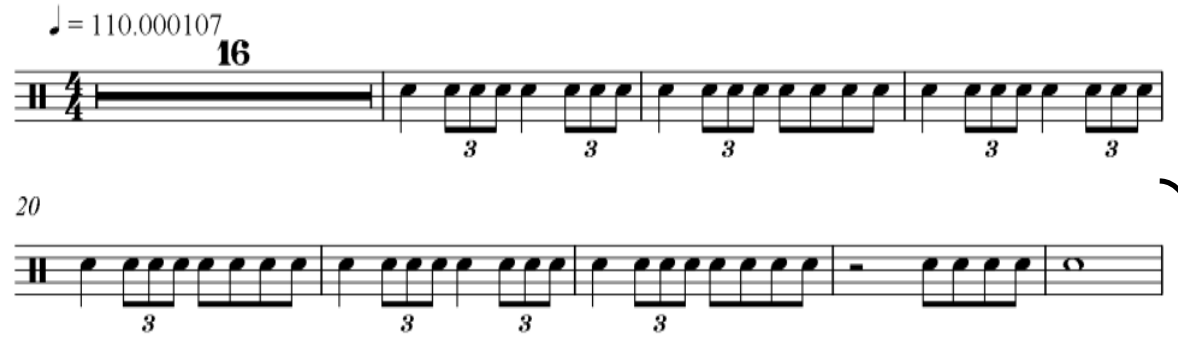

25
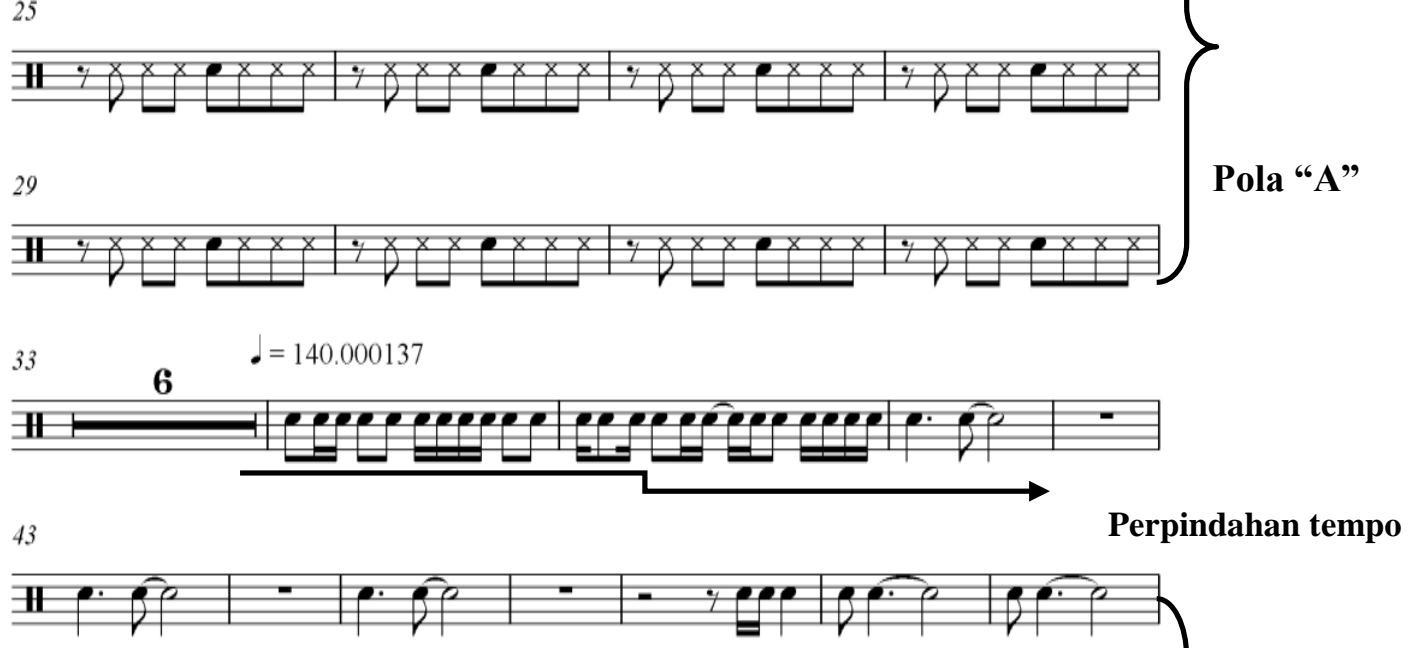

50

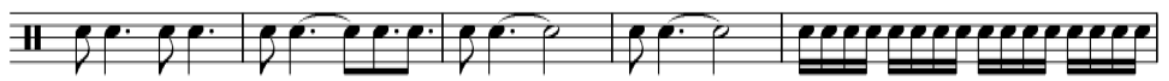

55

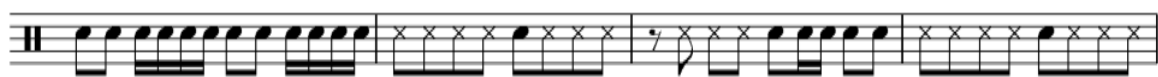

59

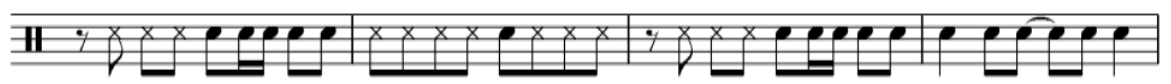

63

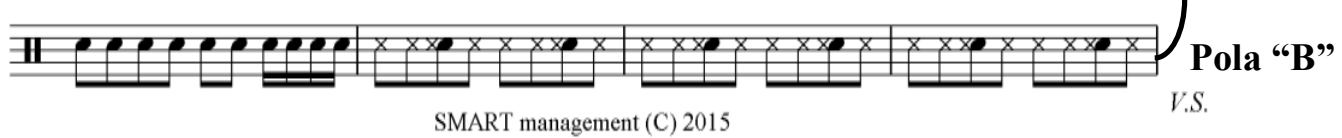




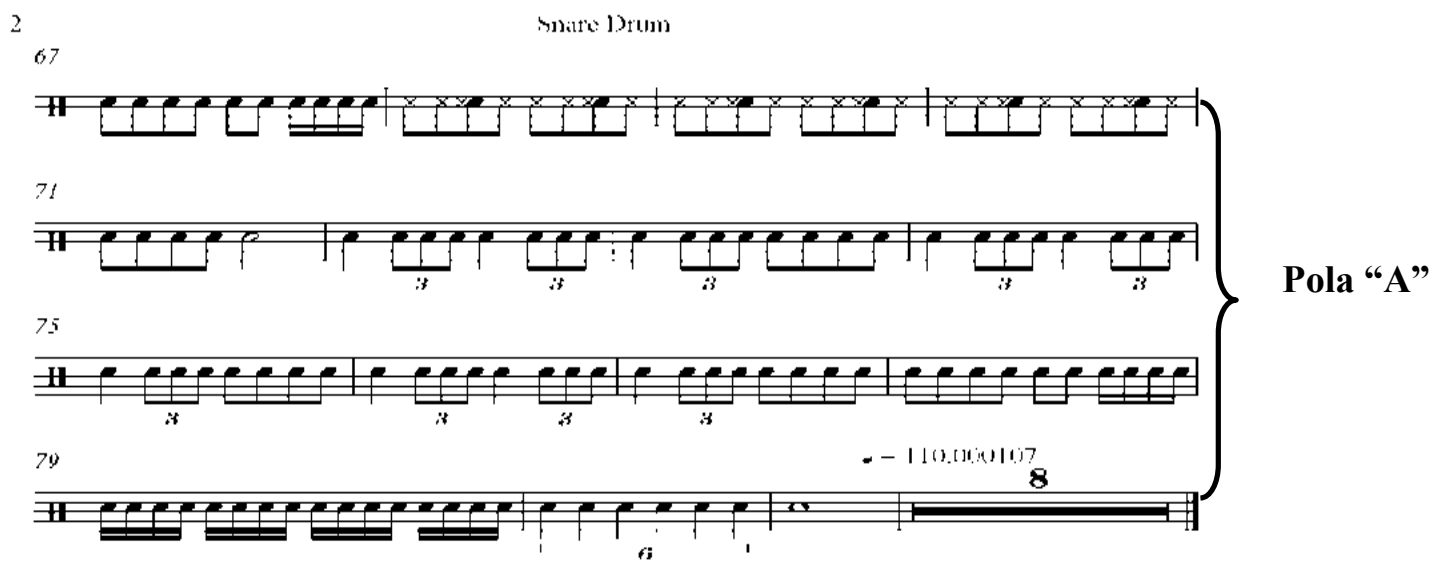

Part 1. Pola Ritme “Untukku” pada Snare Drum

( Sumber : Suroso, 2016)

Dalam aransemen lagu "Untukku” terdapat dua pola untuk snare drum, yaitu pola $\mathrm{A}$ dan pola $\mathrm{B}$, snare drum dalam pola terdapat pada bagian lagu sampai dengan reff, dengan rincian sebagai berikut:

Pada bar ke satu sampai bar ke enam belas snare drum diam, snare drum mulai memainkan pola pada bar ke tujuh belas, dengan not $1 / 4$, not $1 / 8$, not triol, dan dan tempo 110 memainkan pola tersebut sampai pada bar ke tiga puluh dua. Pola yang dimainkan snare drum adalah seperti ini:

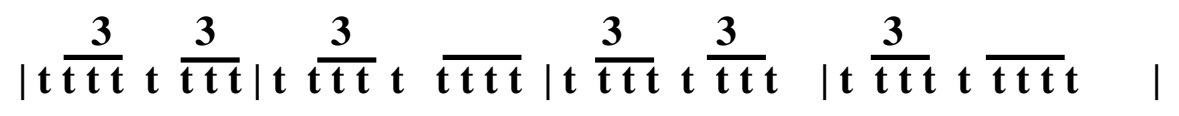

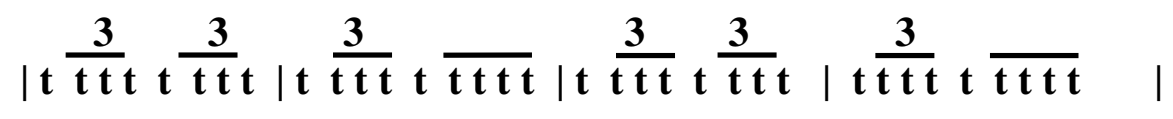

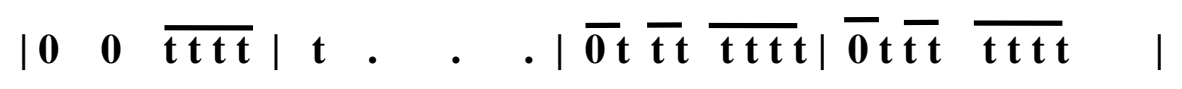

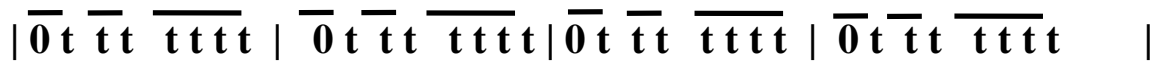




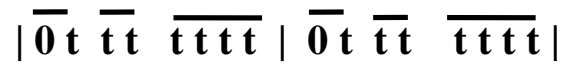

Pada bar ke tiga puluh sembilan sampai pada bar ke delapan puluh dua

terdapat perpindahan tempo dari tempo 110 menjadi 140, snare drum menjadi

jembatan dalam perpindahan tempo tersebut, jembatan perpindahan tersebut pada bar

ke tiga puluh sembilan sampai pada bar ke empat puluh, dengan pola sebagai berikut:

$|\overline{t \bar{t}} \overline{t t} \overline{\operatorname{tat}} \overline{t t}| \overline{t \bar{t}} \overline{t t} \overline{t t t} \overline{t t} \mid$

Permainan pola B dalam snare drum terdapat pada bar ke empat puluh satu sampai bar ke tujuh puluh satu, dalam pola tersebut banyak sekali variasi dan not yang digunakan sangat bervariasi, mulai dari $1 / 8,1 / 16$, dan sampai not $1 / 32$. Pola B dapat dilihat dengan tulisan sebagai berikut:

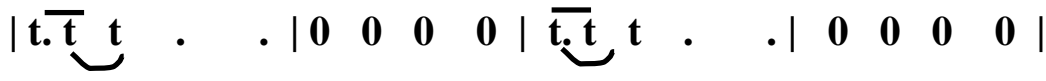

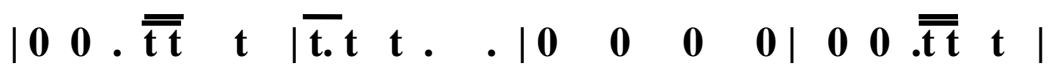

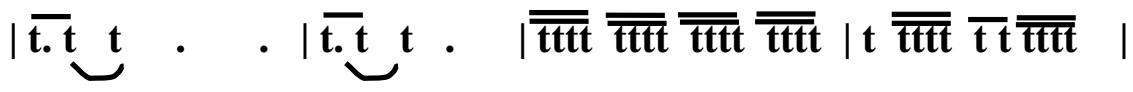

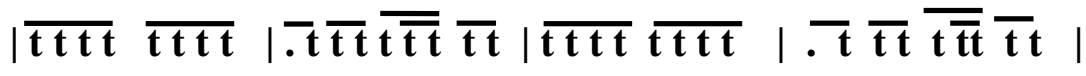

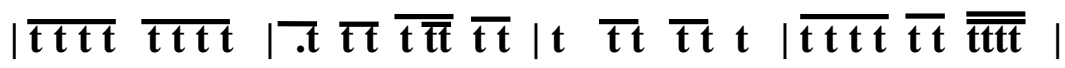

$|\overline{\operatorname{tat}} \overline{\operatorname{tat} t}| \overline{\operatorname{tat}} \overline{\operatorname{tat}}|\overline{\operatorname{tat}} \overline{\operatorname{tat}}| \overline{\operatorname{tat}} \overline{\operatorname{tat} t} \mid$ 


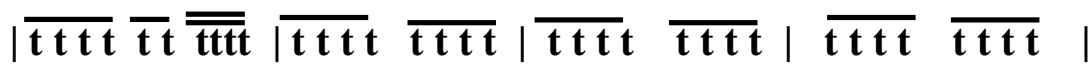

$\overline{\mathbf{t t t t}}$

Berikutnya pada bar ke tujuh puluh satu, snare drum berpindah pola dari pola B ke pola A, dalam permainan pola berikut tidak jauh beda dengan pola A sebelumnya, yang membedakan hanya pada tempo, tempo yang digunakan masih 140 sedangkan tempo sebelumnya adalah 110 dan not yang dimainkannya masih sama yaitu not 1/4, not 1/8, dan not triol, pola A tersebut adalah sebegai berikut:

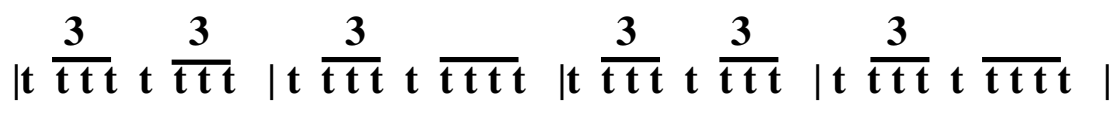

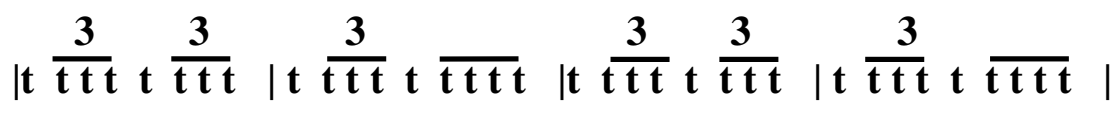

\subsubsection{Cymbals}

Cymbals marching band biasanya terdiri atas dua keping yang terpasang pada ke dua tangan pemainnya. Untuk memainkan cymbals simbal marching band kedua kepingan itu diadu satu dengan lainnya sehingga menghasilkan suara. Jumlah pemain simbal tiap-tiap grup marching band bisa berbeda-beda sesuai dengan kebutuhannya.

Cymbals merupakan alat dalam marching band yang termasuk kedalam devisi perkusi. Pada umumnya alat tersebut berguna untuk memberikan penegasan pada ketukan pertama ataupun pada ketukan terakhir pada sebuah pola ritme 
Partitur di bawah adalah part untuk cymbals, dalam part di atas terdapat tiga pola yaitu pola A,B, dan C. Pola A merupakan bagian dari awal lagu sampai dengan reff, pola B merupakan bagian perpindahan tempo, lagu ke dua, dan interlude sedangkan pola $\mathrm{C}$ merupakan bagian untuk coda atau akhir dari sebuah lagu.

Jymbals
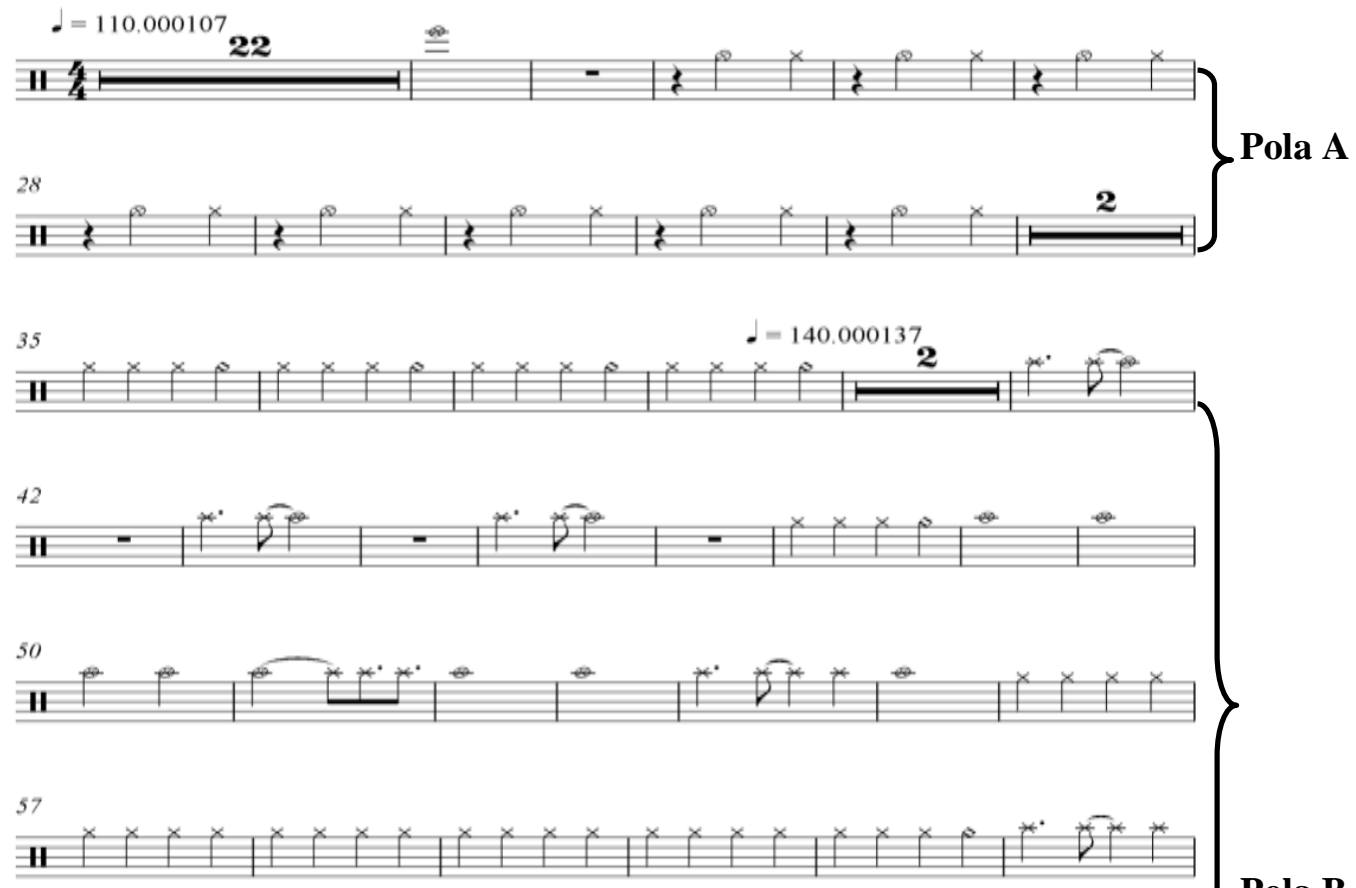

Pola B
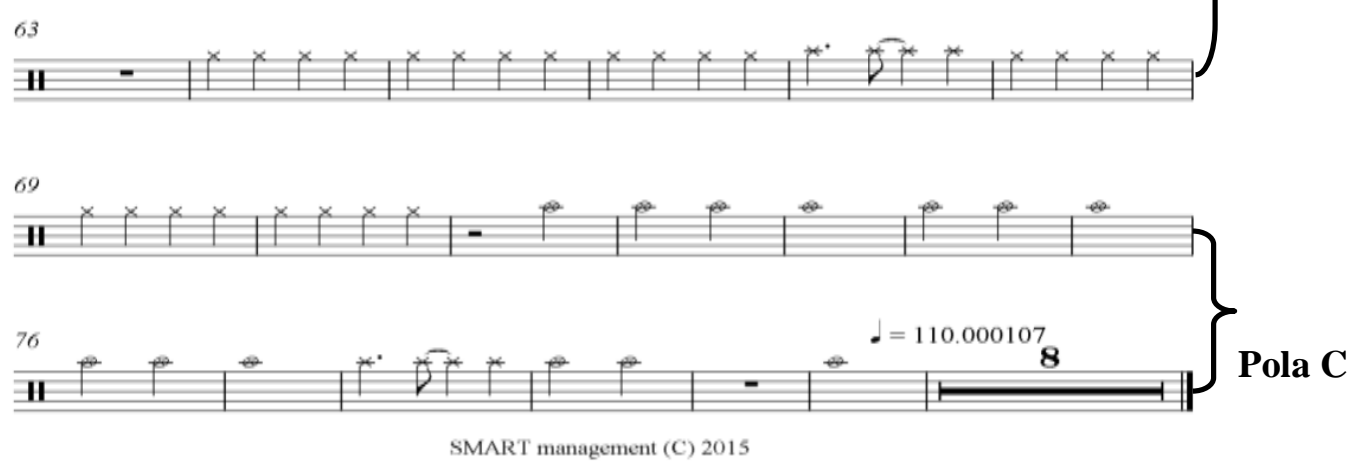

Part 2. Pola Ritme “Untukku” pada Cymbals

( Sumber : Suroso, 2016 ) 
Pola A dalam cymbals menggunakan not 1/4an dengan tempo 110, pola tersebut meliputi intro, lagu, dan reff. Cymbals memainkan pola A pada bar ke dua puluh tiga sampai pada bar ke tiga puluh dua, dapat dijelaskan sebagai berikut:

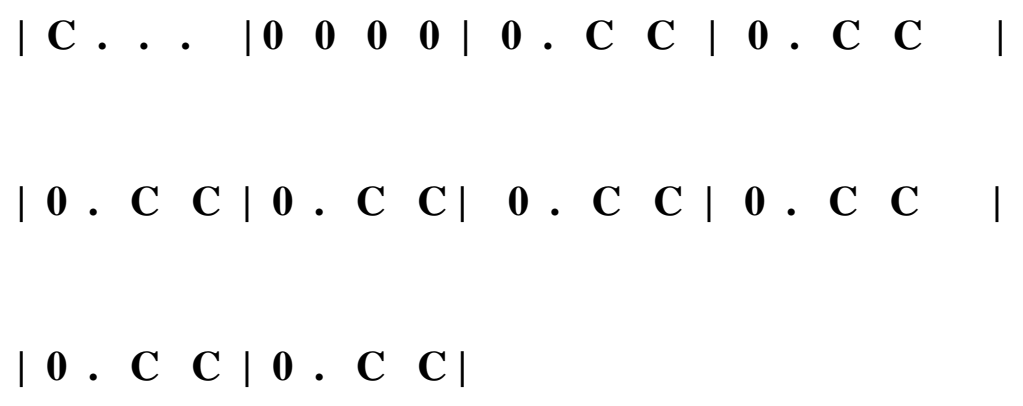


Pola C merupakan pola yang terakhir dalam cymbals pada bagian coda atau penutup dari sebuah lagu, dalam pola tersebut tidaklah rumit dalam permainannya karena dalam pola ini mengguanakn not bernilai dua ketukan, pola $\mathrm{C}$ ada pada bar ketujuh puluh sampai selesai, dengan rincian sebagai berikut:

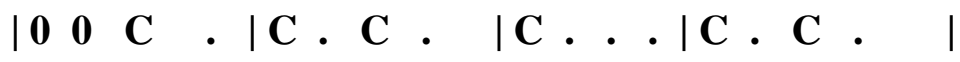

$$
\begin{aligned}
& |\mathrm{C} \cdot \cdot| \mathrm{C} \cdot \mathrm{C} \cdot|\mathrm{C} \cdot \cdot| \overline{\mathrm{C} \cdot \mathrm{C}} \mathrm{C} \mid
\end{aligned}
$$

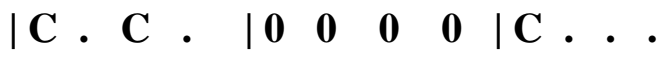

\subsubsection{Bass Drum}

Bass Drum

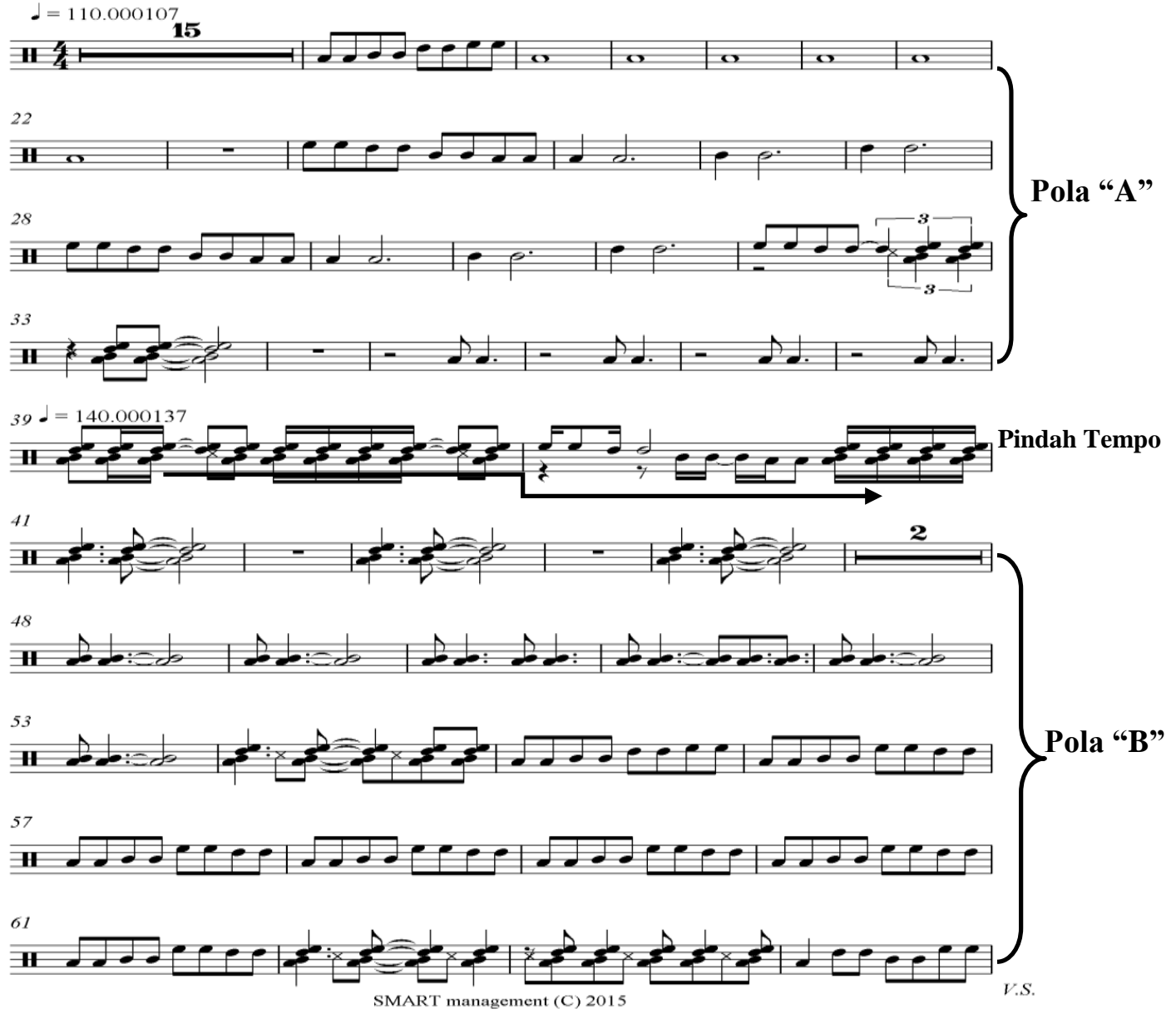




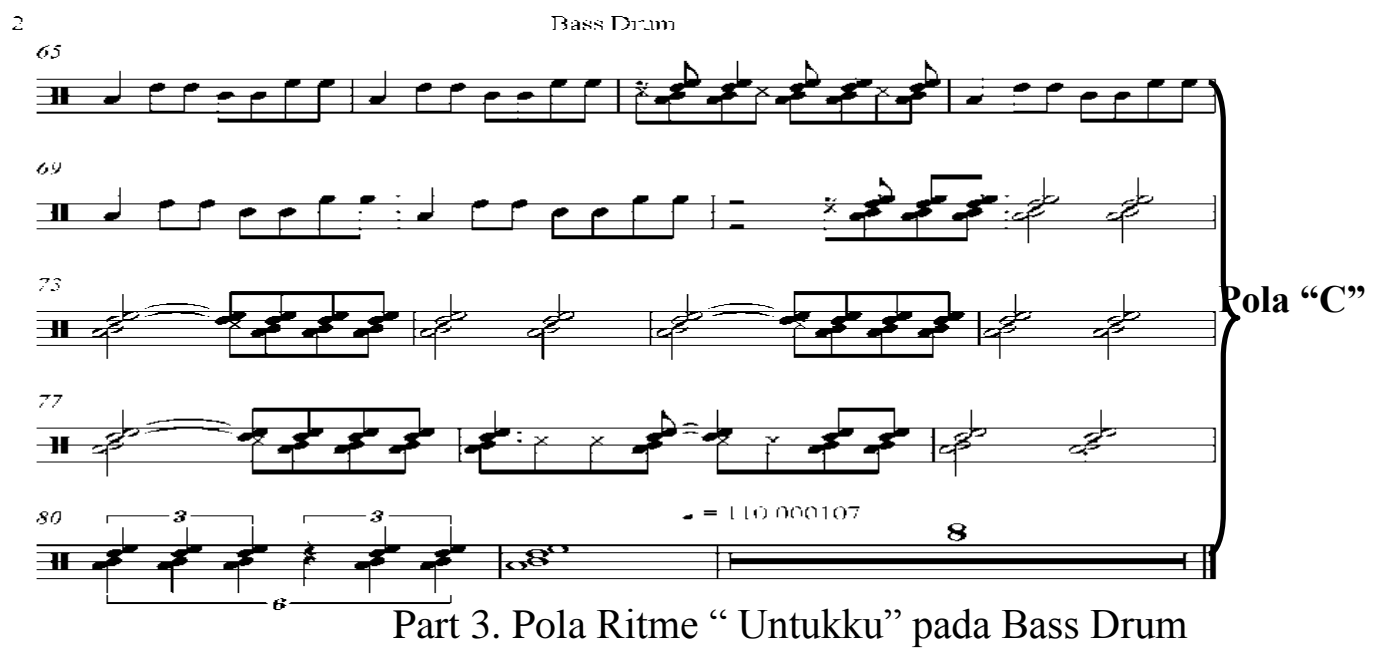

( Sumber : Suroso, 2016 )

Pada bass drum pola A dimulai pada bar ke enam belas sampai ke bar tiga puluh delapan, bar tersebut mencakup lagu sampai dengan reff. Dalam pola A not yang digunakan adalah not $1 / 4$ dan not $1 / 8$ dengan tempo 110 , pola A dapat kita lihat sebagai berikut, suara atau bunyi bass drum pada umumnya berbunyi "dung" maka dari itu penulis menulis dalam pembahasan ini dengan simbol " $\mathrm{D}$ " $|\overline{d d d d} \overline{d d d d}| d \quad . \quad . \quad|d \quad . \quad|. d . . . \mid$

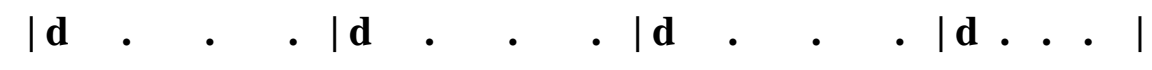

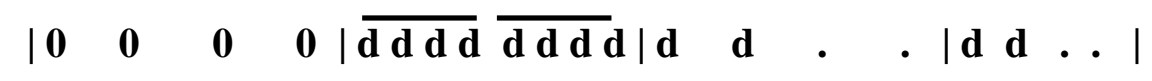

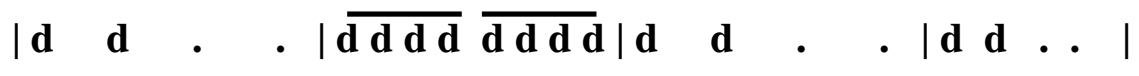

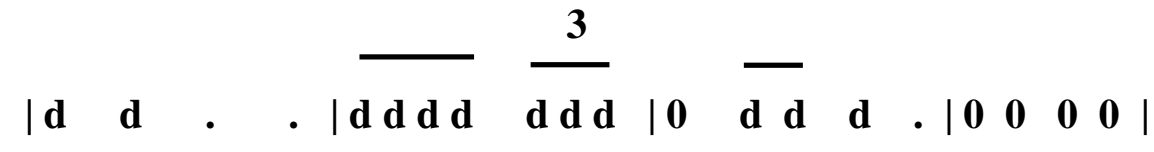


Perpindahan pola terjadi pada bar ke tiga puluh sembilan sampai bar ke empat puluh, bass drum dalam hal itu menjadi jembatan atau pengantar perpindahan tempo dari 110 menjadi 140, dengan pola ritmis sebagai berikut:

$|\overline{d \overline{d d}} \overline{d d} \overline{\overline{d d d d}} \overline{d d} \quad| d \overline{\bar{d} d \bar{d}} \overline{\overline{d d}} \overline{\overline{d d}} \bar{d} \overline{\overline{d d d d}} \mid$

Pada pola B terdapat bagian lagu ke dua yaitu pada bar ke empat puluh satu sampai dengan bar ke enam puluh tiga, dalam pola tersebut bertempo 140 dengan menggunakan not $1 / 4$ dan $1 / 8$. Pola ritmisnya adalah sebagai berikut :

$\left|\begin{array}{lll|llll|lll|llll}\mathbf{d} \overline{. d} & d & \cdot & 0 & 0 & 0 & 0 & \mathbf{d} \cdot \bar{d} & d & \cdot & 0 & 0 & 0 & 0\end{array}\right|$

$\mid$\begin{tabular}{lll|llll|llllll|lllll|}
$\mathbf{d} \overline{. d}$ & $d$ & $\cdot$ & 0 & 0 & 0 & 0 & 0 & 0 & 0 & 0 & 0 & 0 & 0 & 0 &
\end{tabular}

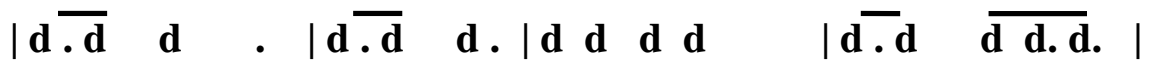

|d.df d . |d.df d. | $\overline{d d d d} \overline{d d d d ~}|\overline{d d d d ~} \overline{d d d d}|$

$|\overline{d d d d} \overline{d d d d}| \overline{d d d d} \overline{d d d d}|\overline{d d d d} \overline{d d d d}| \overline{d d d d} \overline{d d d d} \mid$

$|\overline{d d d d} \overline{d d d d}| \overline{d d d d} \overline{d d d d} \mid$

Pada pola yang $\mathrm{C}$ terdapat pada bagian lagu interlude hingga menuju coda yang berada pada bar ke 65 bar ke delapan puluh, denga pola sebagai berikut:

|d $\overline{d d}$ d d d d |d $\overline{d d}$ d d d d |dddd d d d d |

$|d \overline{d d} \overline{d d d d}| d \overline{d d} \overline{d d d d}|\overline{d \overline{d d}} \overline{d d d d}|$

|d $\overline{d d} \overline{d d d d} \mid \begin{array}{llllll}0 & 0 & \overline{d d d d} & \mid d & . & d\end{array}$

$|d . \overline{d d d d} \quad| d . d . \quad|d \cdot \overline{d d d d}| d . \quad$. $\quad$. $\mid$

$|d \cdot \overline{d d d d} \quad| d \cdot d \cdot|d \cdot \overline{d d d d}| \overline{d d d d} \overline{d d d d} \mid$ 
$\mid d \quad \cdot \quad$ d.$\quad\left|\overline{d d d} 0 \frac{3}{d d d}\right|$

\subsubsection{Quartom}

Quarts toms merupakan alat perkusi di dalam marching band, bentuk dari alat tersebut adalah aplikasi dari empat bass yang menjadi satu, pada quart toms ada empat membran dimulai dari membran yang terkecil sampai yang terbesar. Pola pada quart toms tersebut ada empat yaitu pola A,B,C,D.

Pola "A" yang dimainkan quart toms meliputi pada bar ke dua puluh tiga sampai pada bar ketiga puluh tiga yaitu pada reff sampai menjelang perpindahan tempo, dengan tempo 110 dan not yang dimainkan adalah not 1/8,1/16 dan triol, dengan pola sebagai berikut:

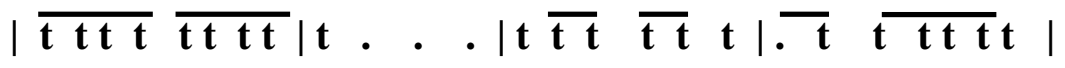

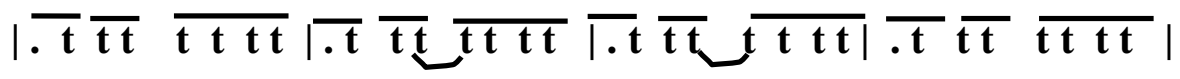

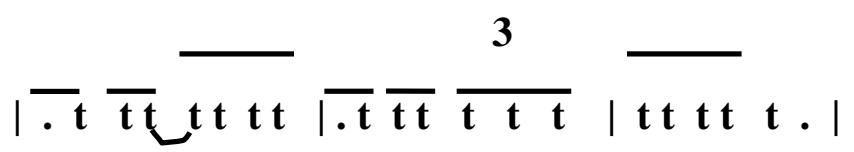


Sedangkan pada pola berikutnya yaitu pola yang "B" merupakan lagu setelah reff terdapat pada bagian bar ke empat puluh tiga sampai pada bar ke lima puluh empat, not yang digunakan hampir sama dengan pola " $\mathrm{A}$ ” namun terdapat perbedaan, pada pola "B" tidak menggunakan not triol tempo yang digunakan bertempo 140, dengan pola sebagai berikut:

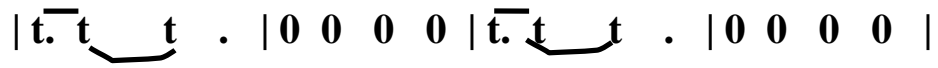

$|\bar{t} . \underbrace{t} \mathbf{t} \cdot| \begin{array}{llll}0 & 0 & 0 & 0\end{array}|\bar{t} . \underbrace{t} t \cdot| \begin{array}{llll}0 & 0 & 0 & 0\end{array} \mid$

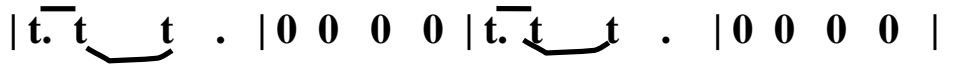


Quart Toms
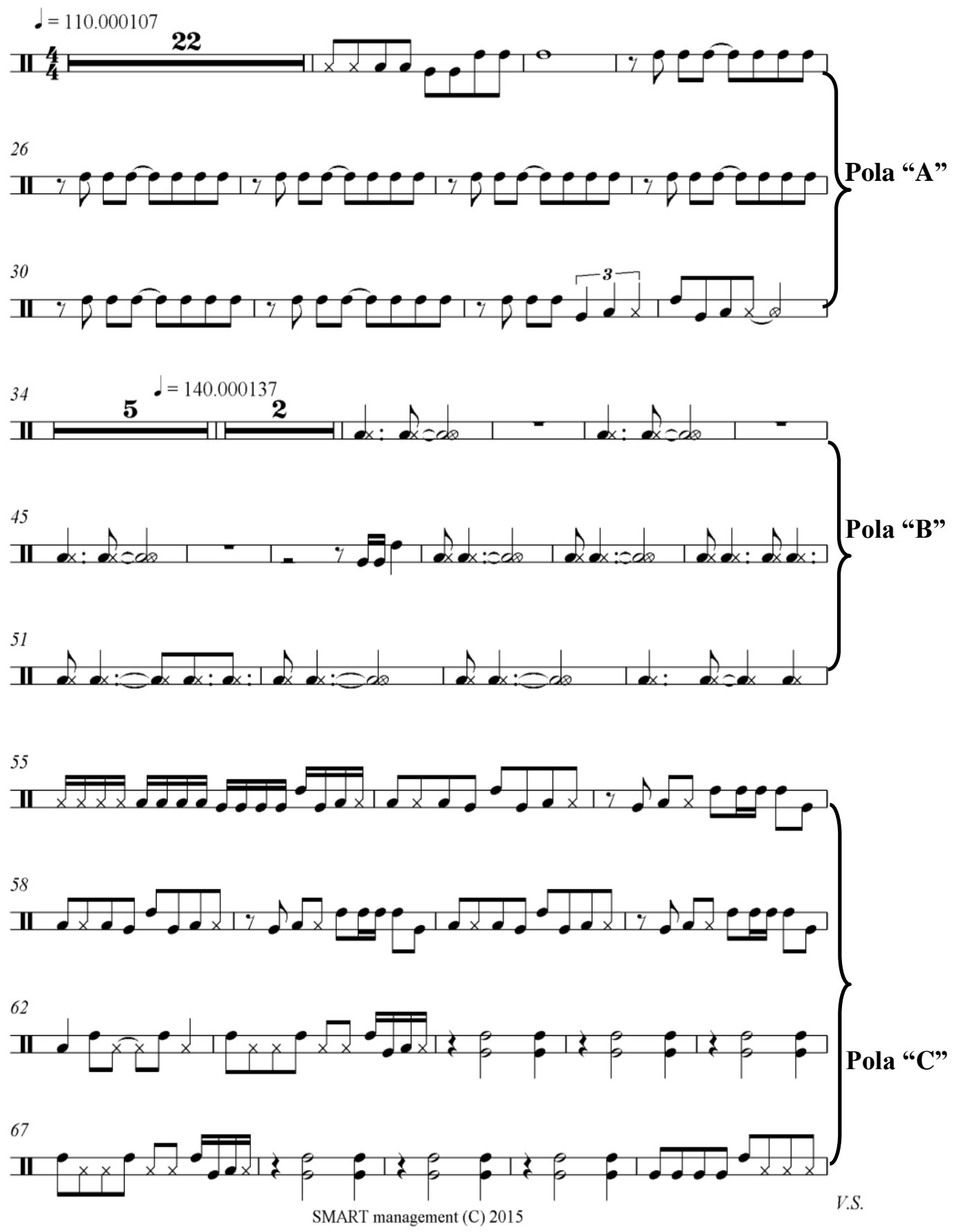


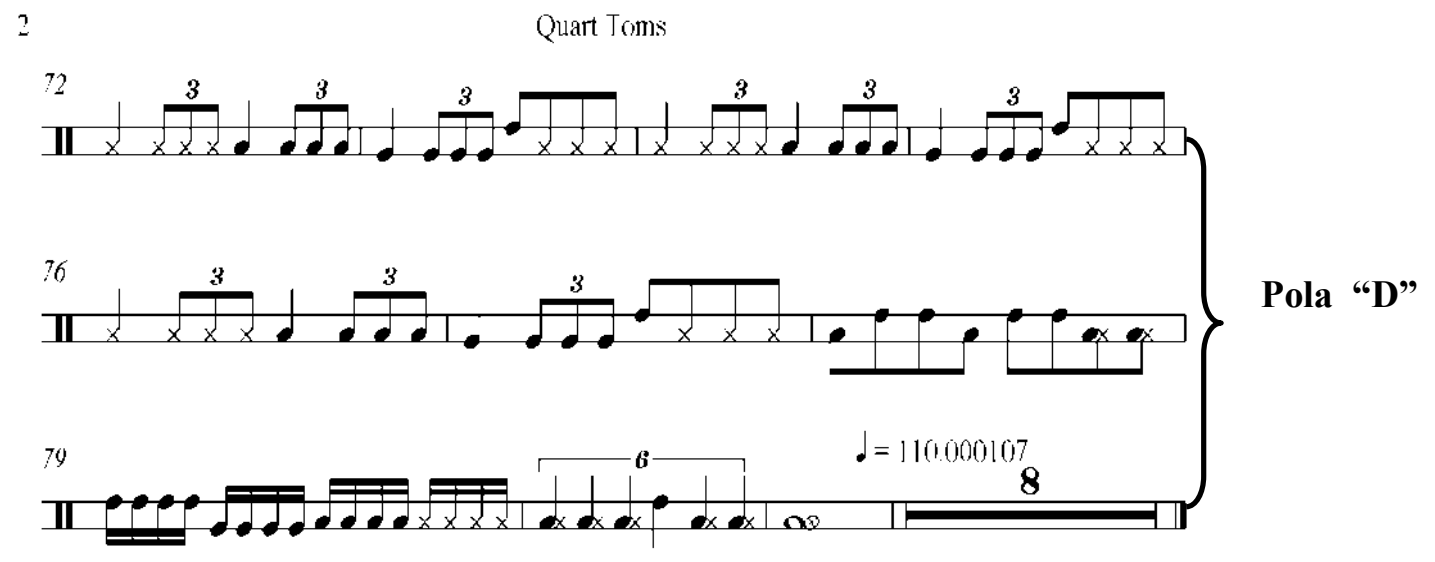

Part 4. Pola Ritme “Untukku” pada Quartom

( Sumber : Suroso, 2016 )

Pada pola berikutnya yaitu pola yang "C" merupakan lagu kedua dan interlude terdapat pada bagian bar ke lima puluh lima sampai pada bar ke tujuh puluh satu, perbedaan dengan pola sebelumnya adalah, pada pola "C" menggunakan not 1/32 tempo 140, dengan pola sebagai berikut:

$|\overline{\overline{\mathrm{tttt}}} \overline{\overline{\mathrm{tttt}}} \overline{\overline{\mathrm{tttt}}} \overline{\overline{\mathrm{tttt}}}| \overline{\mathrm{ttt}} \overline{\mathrm{ttt}}|\overline{. t} \overline{\overline{\mathrm{tt} t}} \mathrm{t} \overline{\mathrm{t}}|$

$|\overline{\operatorname{tat}} \overline{\operatorname{tatt}}| \overline{\cdot t} \overline{\operatorname{tat}} \overline{\operatorname{tatt}}|\overline{\operatorname{tat}} \overline{\operatorname{tat}}|$

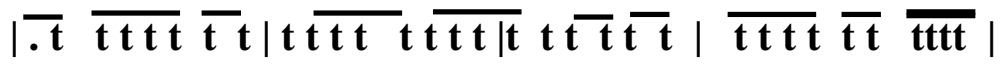


Pada pola berikutnya yaitu pola yang " $\mathrm{D}$ " merupakan interlude yang menuju ke coda terdapat pada bagian bar ke tujuh puluh dua sampai pada bar ke delapan puluh, dengan pola sebagai berikut:

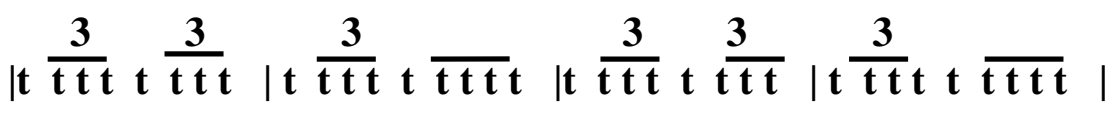

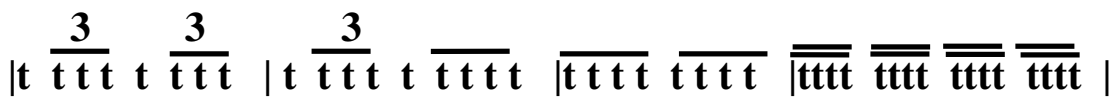

\subsubsection{Melodi Lagu}

Menurut (Widia Pekerti dkk, 2005 : 220 ) melodi adalah berbagai tinggi dan rendah nada dikombinasikan dengan nilai nada. Dapat disimpulkan bahwa melodi adalah serangkaian nada yang memiliki tinggi rendah dan panjang pendek yang berbeda. Dalam mengaransemen melodi yang digunakan haruslah sesuai atau tidak melenceng dari lagu tersebut, sehingga lagu yang terdengar akan terasa indah.

Dalam aransemen marching band pada umumnya pemegang melodi atau yang memainkan melodi adalah pada devisi brass dan devisi pitch. Devisi brass atau devisi tiup meliputi: trumpet, mellophone, cornet, french horn, trombone sedangkan pada devisi pitch meliputi: bells, marimba, vibraphone, dana xylpohone. Pada umumnya dalam aransemen marching band, devisi brass merupakan melodi utama dan merupakan devisi yang mamainkan akor dalam sebuah lagu, sedangkan devisi pitch 
pada umumnya adalah sebagai ornamen atau melodi untuk mengiringi lagu dan memperindah lagu.

Lagu "Untuku” yang digunakan Marching Band Domenico Savio Semarang, merupakan lagu yang telah diaransemen, dalam aransemen melodi pada lagu tersebut, terdapat beberapa perbedaan dengan lagu aslinya, ada terdapat beberapa bagian yang diubah, dan dalam aransemen tersebut terdapat juga nuansa yang disesuaikan dengan tempat perlombaan dalam aransemen ini, peneliti akan memaparkan beberapa instrument melodi yang telah diaransemen.

Peneliti akan menjabarkan beberapa isntrument yang memainkan melodi, dari alat tiup dan alat perkusi yang bernada. Alat musik melodi Marching Band Domenico Savio Semarang seperti trumpet, mellophone, bells, xylophone, dan vibraphone yang nantinya akan dikaji bagaimana melodi yang digunakan dalam aransemen lagu "Untukku" yang dimana aransemen lagu tersebut digunakan dalam mengikuti perlombaan Hamengkubuwono Cup 2015 yang diselenggarakan di Yogyakarta. 


\subsubsection{Trumpet 1}

Instrument trumpet adalah instrument tiup yang termasuk dalam keluarga tiup logam, alat ini merupakan alat yang memiliki suara tinggi, bernada dasar $\mathrm{B}^{\mathrm{b}}$ atau $\mathrm{B}^{\mathrm{b}}=$ Do. Dengan urutan nada sebagai berikut $\mathrm{B}^{\mathrm{b}} \mathrm{C}$ D E $\mathrm{E}^{\mathrm{b}} \mathrm{F}$ G A B $\mathrm{B}^{\mathrm{b}}$ (Do Re Mi Fa So La Si Do ).

Trumpet - 1
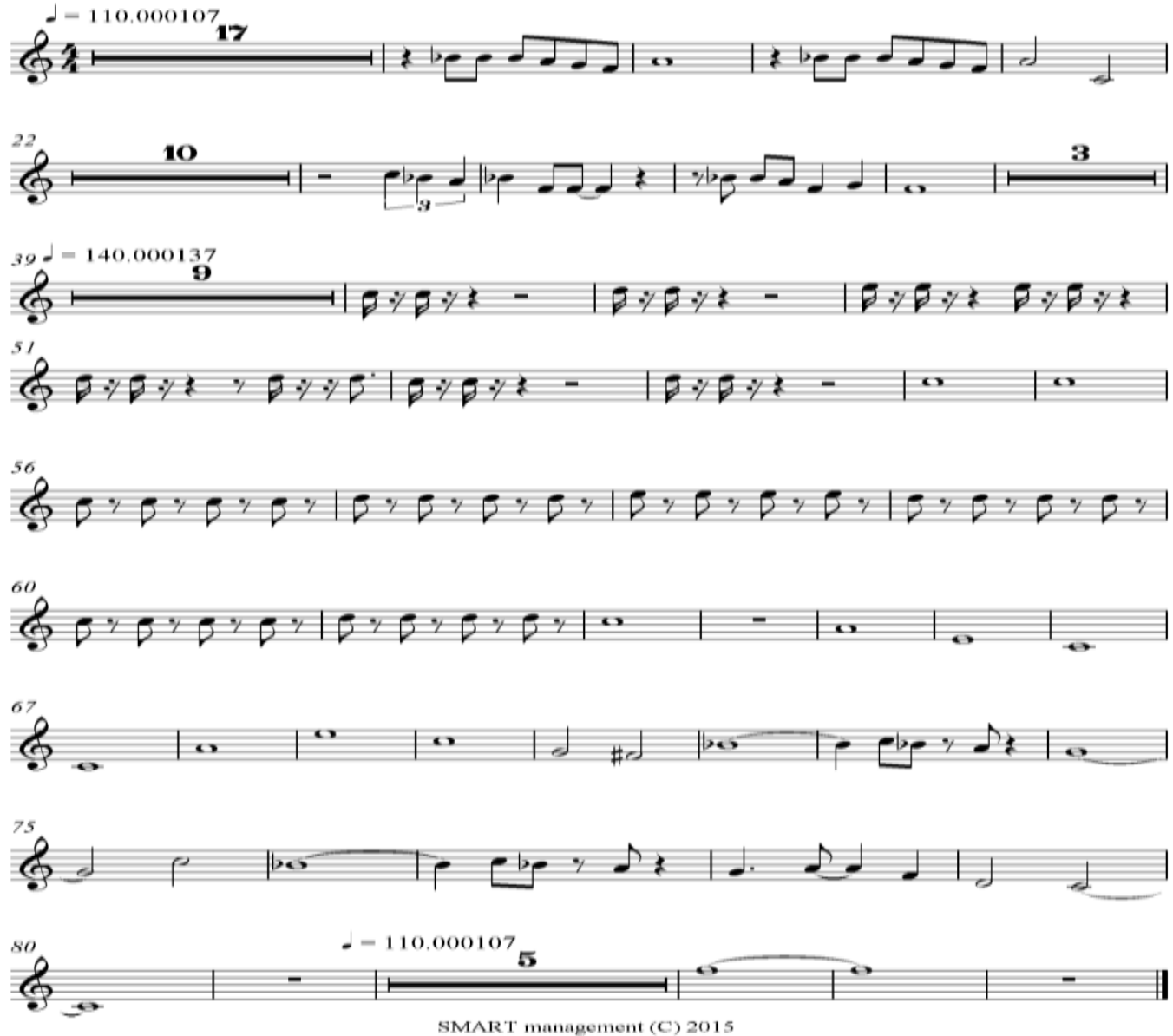

Part 5. Melodi lagu "Untukku” pada trumpet 1

( Sumber : Suroso, 2016 ) 
Untuk membaca part trumpet 1 di atas menggunakan sistem baca system fixed do, yang dimaksud system fixed do adalah latihan nada-nada dinyanyikan dengan apa adanya, misalkan nada $\mathrm{C}$ tetap dibaca do meskipun dalam tangga nada yang berbedabeda. Contoh lain, menyanyikan lagu nada F mayor (1 mol) maka nada F tidak dibaca do melainkan fa (http://edwinssuryaputra.wordpress.com /2013/ 11 /28 /teori solfegio). Maksud dari pendapat tersebut adalah, apabila membaca nada $\mathrm{C}$ dalam tangga nada $\mathrm{G}=$ do maka nada $\mathrm{C}$ tersebut tetap dibaca sebagai do.

Dalam membaca part trumpet 1 pun demikian, part trumpet 1 bertangga nada C natural, membaca notasi dan meniup melodinya pun sesuai dengan nada yang sudah ada pada part tersebut.

Dari partitur trumpert 1 di atas dapat dijelaskan sebagai berikut: trumpet 1 selama 17 bar atau 69 ketuk tidak memainkan nada apapun atau dapat dikatakan diam dengan tempo 110. Pada ketukan ke 70 barulah memainkan melodi dengan nada

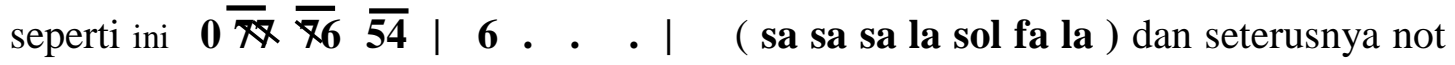
yang digunakan merupakan not 1/8 yang dapat pelajari dan dimainkan oleh siswa.

Tangga nada yang dipakai dalam part trumpert 1 ini adalah $\mathrm{C}=$ do, namun dalam meniup atau memainkan melodi trumpert sesuai harus dengan nada yang dihasilkan, maksudnya adalah seperti ini apabila dalam part tersebut $\mathrm{C}=(1 \mathrm{do})$ maka pemain trumpet pun meniup nada (do 1 ) tetapi dalam tangga nada $\mathrm{B}^{\mathrm{b}}$, dan ternyata instrument trumpet yang biasa dalam marching merupakan melodi utama, dalam partitur di atas ternyata tidak sebagai pemegang melodi utama, melainkan sebagai penamis. Pada bar ke 39 terdapat perubahan tempo dan suasana lagu, tempo yang 
bermula 110 menjadi 140 dan suasana yang awalnya santai menjadi riang gembira ditambah dengan memainkan not 1/32 serta diwarnai dengan sinkop - sinkop.

\subsubsection{Trumpet 2}

Dalam lagu "Untukku” yang diaransemen, instrument trumpet terbagi menjadi 3 bagian, bagian yang kedua yaitu trumpet 2 masuk memainkan melodi pada bar 16 sampai bar 23 dengan tanda birama 4/4, tempo 110 dan memainkan melodi asli dari lagu "Untukku”. Dengan nada sebagai berikut:

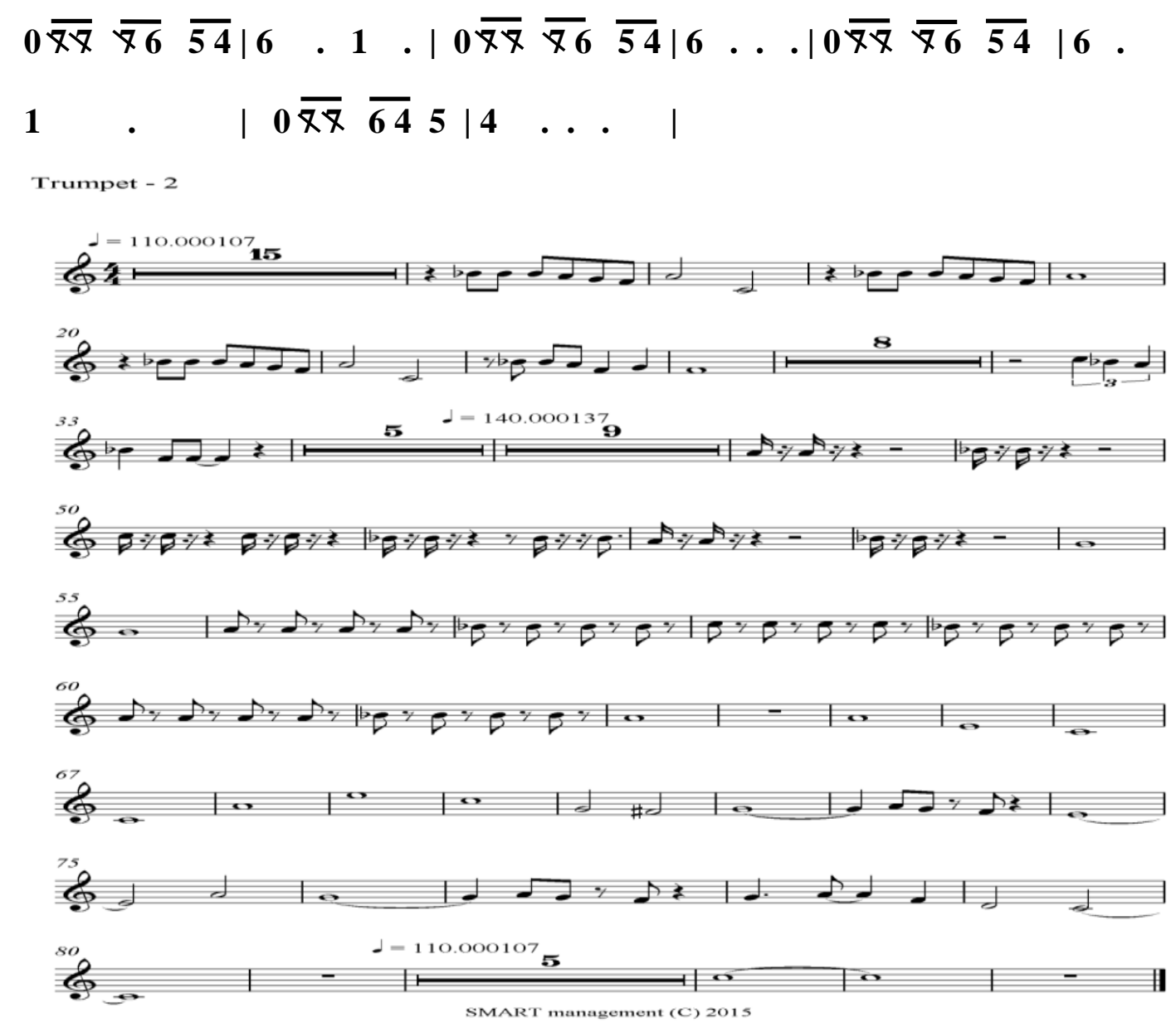

Part 6. Melodi lagu "Untukku” pada trumpet 2

( Sumber : Suroso, 2016 ) 
Kemudian pada bar 24 sampai bar 31 yaitu pada saat reff trumpet 2 diam setelah itu bernyanyi lagi selama 2 bar, dan kemudian diam kembali selama 14 bar. Terdapat perubahan tempo dan pola di bar ke 39 tempo berubah menjadi 140 dan pola permainan trumpet yang awalnya memainkan not $1 / 8$ berubah menjadi not $1 / 32$ dan pada lagu kedua peranan yang dipegang oleh trumpet 2 berubah dengan meniup nada dari unsur akor secara stacato untuk memperkuat akor penegasan akor dalam lagu tersebut.

\subsubsection{Trumpet 3}

Melihat partitur trumpet 3 di bawah dapat dijelaskan bahwa trumpet 3 merupakan penamis dalam aransemen tersebut, dikatakan seperti itu karena, trumpet 3 tidak banyak memainkan nada asli. Pada bagian intro yaitu pada bar 1 sampai bar ke 7, dan lagu dari bar 8 sampai bar 15 trumpet 3 diam. Trumpet 3 baru memainkan melodi pada bar 16 dengan melodi sebagai berikut:

\section{$0 \overline{\bar{X}} \overline{\bar{X}_{6}} \overline{54}|6 \quad \cdot 1 \cdot|$ ( sa sa sa la sol fa la do)}

setelah itu trumpet 3 diam selama 14 bar, berbunyi lagi pada bar ke 32 selama 2 bar dengan nada sebagai berikut :

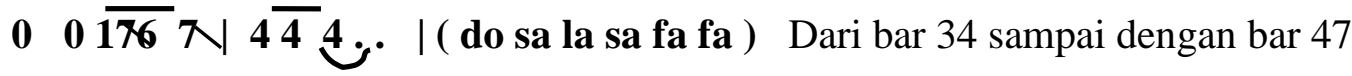

trumpet 3 diam, pada bar ke 48 terdapat perubahan tempo dan perubahan pola

permainan, tempo yang bermula 110 menjadi 140, permainan yang mulanya

memainkan melodi berubah menjadi memainkan penegas akor dengan meniup nada secara stacato atau terpatah-patah dan diselingi dengan long tone (nada panjang) 
dengan not $1 / 32$ dan not $1 / 16$, nada yang ditiup merupakan unsur dari akor yang ditiup secara terpatah-patah, dengan nada unsur dari akor IV dan akor V seperti ini :

\section{\begin{tabular}{llll|llll|lll|}
40 & 40 & 40 & 40 & 60 & 60 & 60 & 60 & 5 & $\ldots$
\end{tabular}}

Trumpet - 3
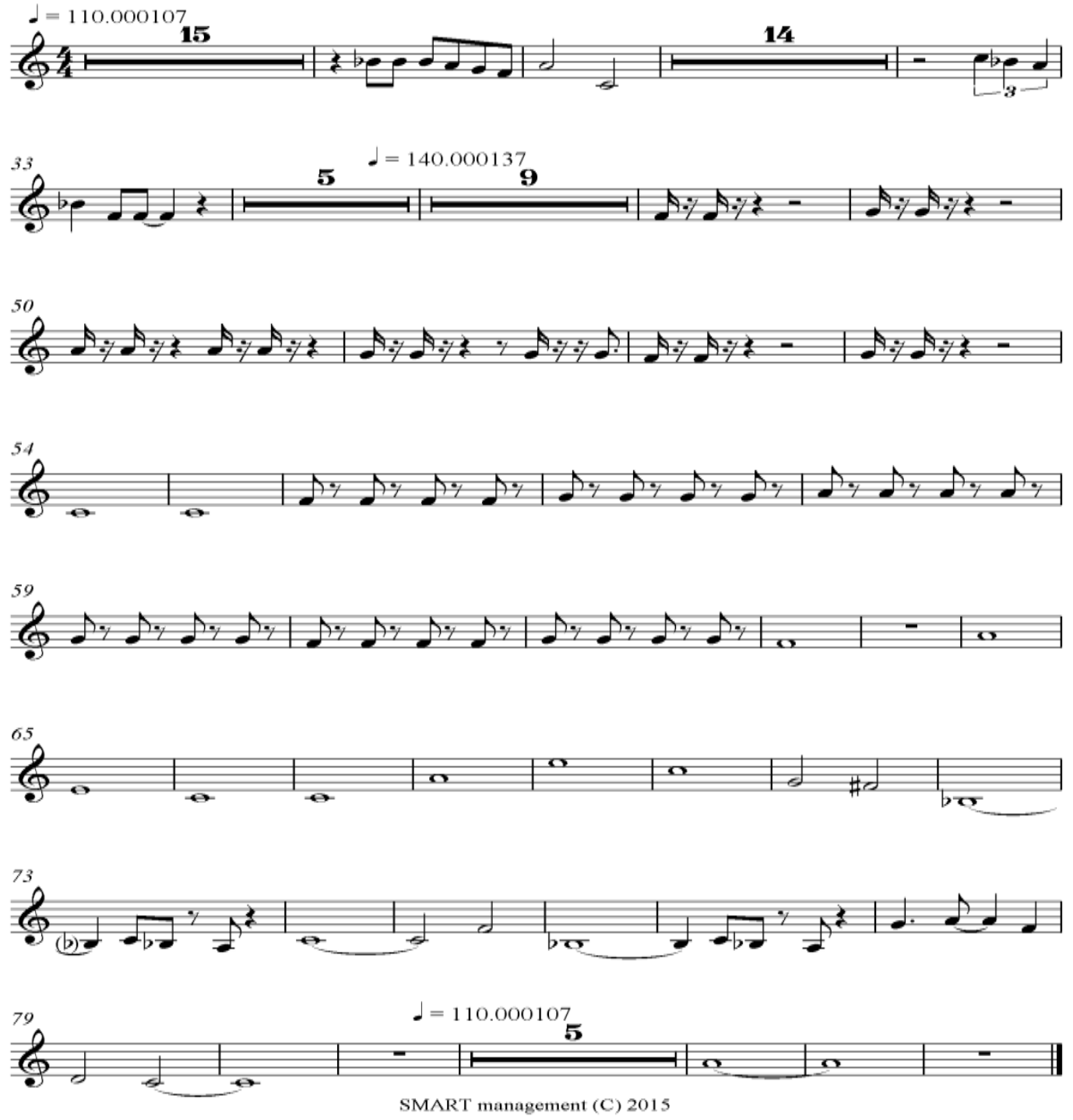

Part 7. Melodi lagu "Untukku” pada trumpet 3

( Sumber : Suroso, 2016 


\subsubsection{Mellophone}

Mellophone merupakan isntrument tiup logam atau brass, isntrument tersebut dalam marching band berfungsi sebagai penamis dalam sebuah lagu, karakter dari suara mellophone adalah karakter lembut atau nada yang dihasilkan merdu, nada dasar dari mellophone adalah $\mathrm{F}$ atau $\mathrm{F}=$ do penulisan dalam part mellophone berbeda dengan instrument yang lain. Dalam aransemen lagu "Untukku" mellophone kebanyakan memainkan melodi asli, untuk mengetahui lebih jelas lagi berikut adalah partitur dari mellophone:

Mellophone
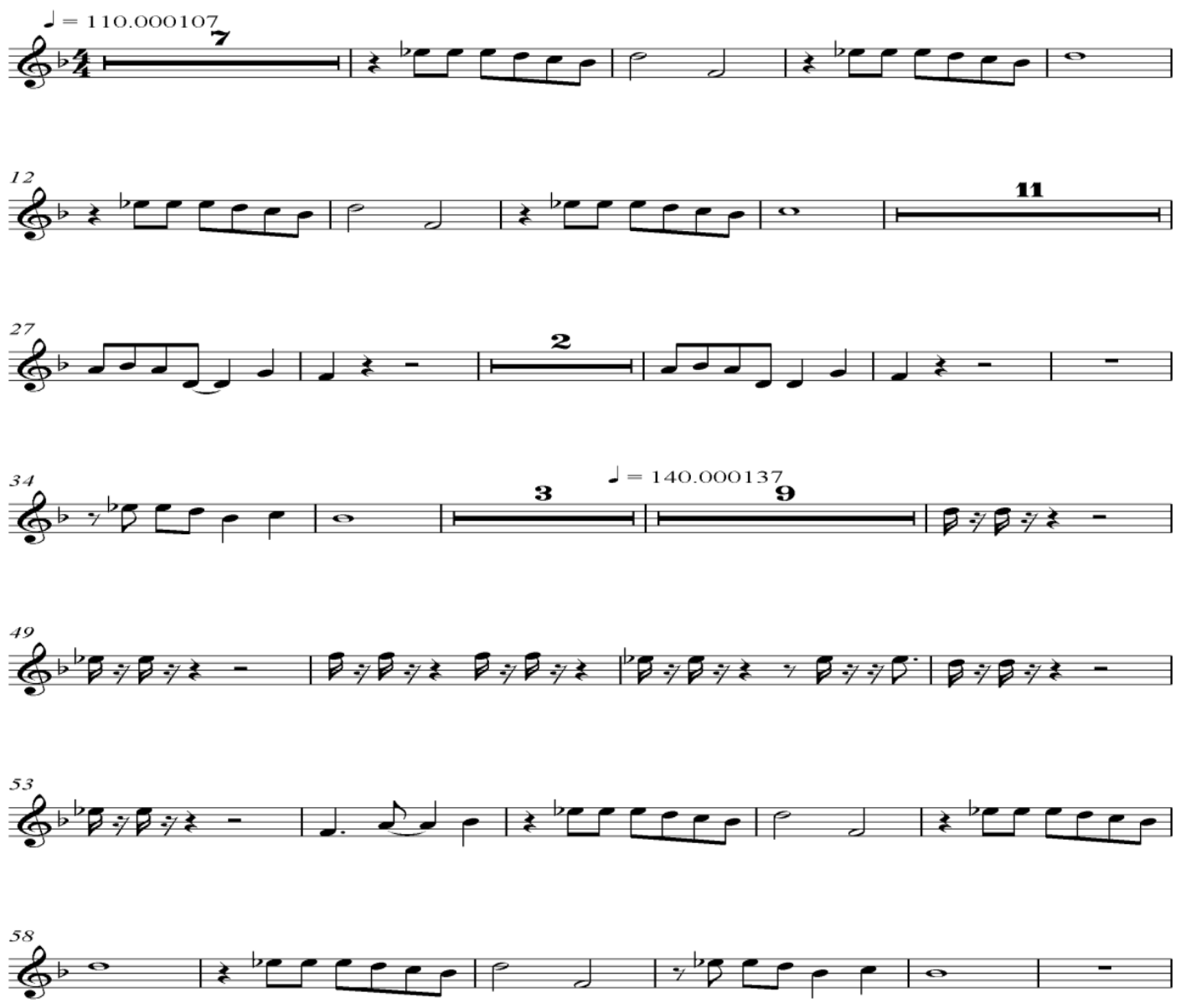

SMART management (C) 2015 


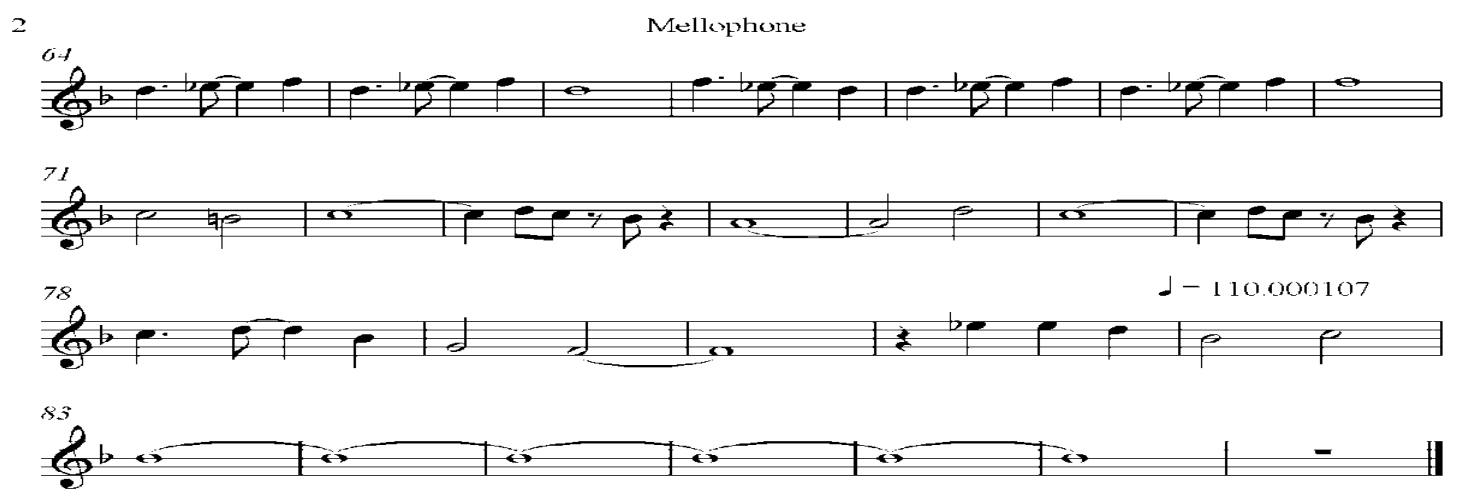

Part 8. Melodi lagu "Untukku” pada mellophone

( Sumber : Suroso, 2016)

Partitur di atas merupakan partitur untuk mellophone, pembahasan mengenai mollophone dapat dijelaskan sebagai berikut: mellophone pada waktu intro yaitu pada bar ke 1 sampai dengan bar ke 7 diam, memainkan melodi lagu mulai pada bar ke 8 sampai dengan bar ke 14 dengan menggunakan not 1/8. Melodi yang dimainakan mellophone adalah melodi asli yang sama dengan lagu "Untukku" dimulai dari bar 8 sampai bar 15 dengan melodi sebagai berikut:

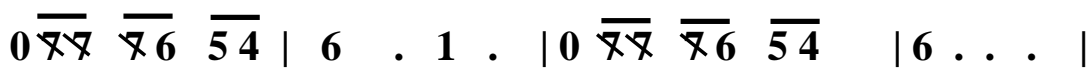

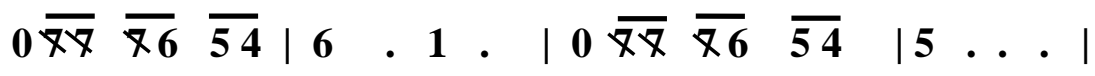

Setelah memainkan melodi tersebut mellophone selama 11 bar, pada bar ke 22 mellophone memainkan lagi melodi kembali selama 2 bar dan diam selama 2 bar pada bar ke 34 kembali memainkan melodi selama 2 bar. Terdapat perpindahan tempo dan pola permainan di bar ke 48 dalam lagu "Untukku", tempo yang awalnya 110 menjadi 140 


\subsubsection{Bells}

Belss merupakan instrument atau alat musik yang merupakan bagian dari devisi perkusi, atau dapat dikatakan alat musik ini adalah perkusi yang bernada, cara memainkan alat musik tersebut adalah dengan dipukul, alat musik bells terbuat dari bilahan-bilahan logam yang apabila dipukul mempunyai nada yang berbeda antara satu nada dengan nada yang lainnya.

Dalam lagu "Untukku” bells memainkan melodi pada nada dasar $\mathrm{B}^{\mathrm{b}}$ birama pada lagu tersebut adalah 4/4, untuk lebih jelas kita dapat melihat part untuk bells di bawah.

Apabila diamati pada part di bawah, bells dalam part tersebut lebih banyak memainkan melodi yang baru yang berfungsi sebagai isian atau pengisi dalam kekosongan lagu. Bar ke 1-4 bels diam, instrument bells pada bar ke 5 mulai memainkan sebuah melodi intro yang sama dengan melodi intro lagu asli sampai bar ke 14, dengan melodi sebagai berikut :

\section{$|\overline{46} \overline{14} 4 \cdot| \overline{5 \times} \overline{25} \cdot|\overline{61} \overline{46} \cdot| \overline{58} \overline{25} \cdot \mid$}

\section{$|\overline{46} \overline{14} 4.| \overline{5 \times} \overline{25} 5 .|\overline{61} \overline{46} 6 \cdot| \overline{5 \times} \overline{25} 5 . \mid$}

Pada bar ke 15 bells memainkan melodi dengan memukul dua nada sekaligus dalam satu pukulan, melodi yang dipukul atau dimainkan adalah sebagai berikut:

0 $\overline{\mathbf{1 1}} \overline{\mathbf{1 8 6 5}} \mid$ melodi tersebut merupakan jembatan untuk menghubungkan dengan lagu ke 2. Terdapat pergantian tempo dalam lagu untuk pada bar ke 39, dalam melodi bells juga terdapat pergantian, melodi yang dibunyikan bells pada bar ke 45-47 merupakan melodi pentatonis dan bells pun memainkan akor pada bar 48 sampai bar 
ke 53 dengan not 1/32 dan membunyikan nada yang merupakan unsur dari sebuah akor.

Bells
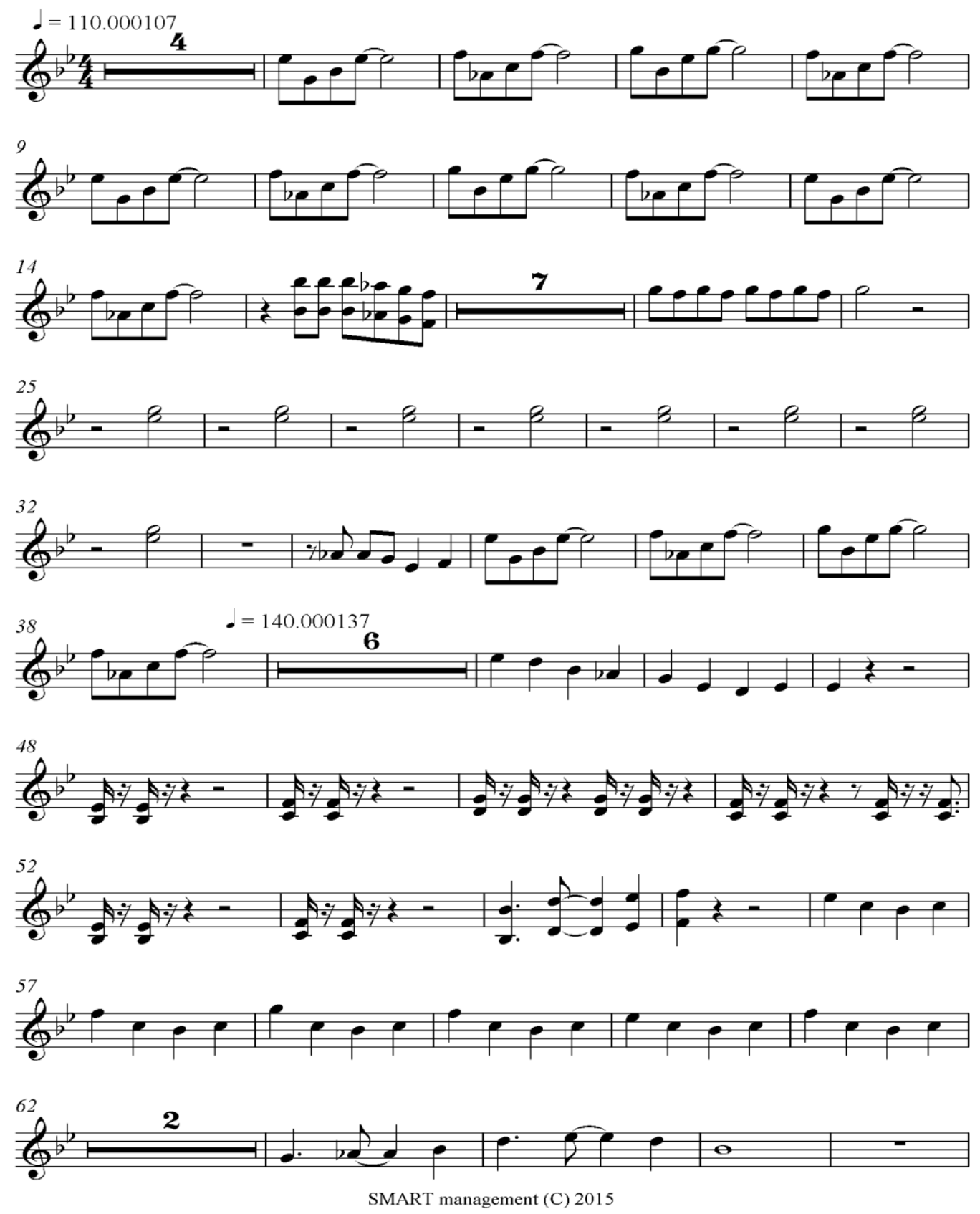


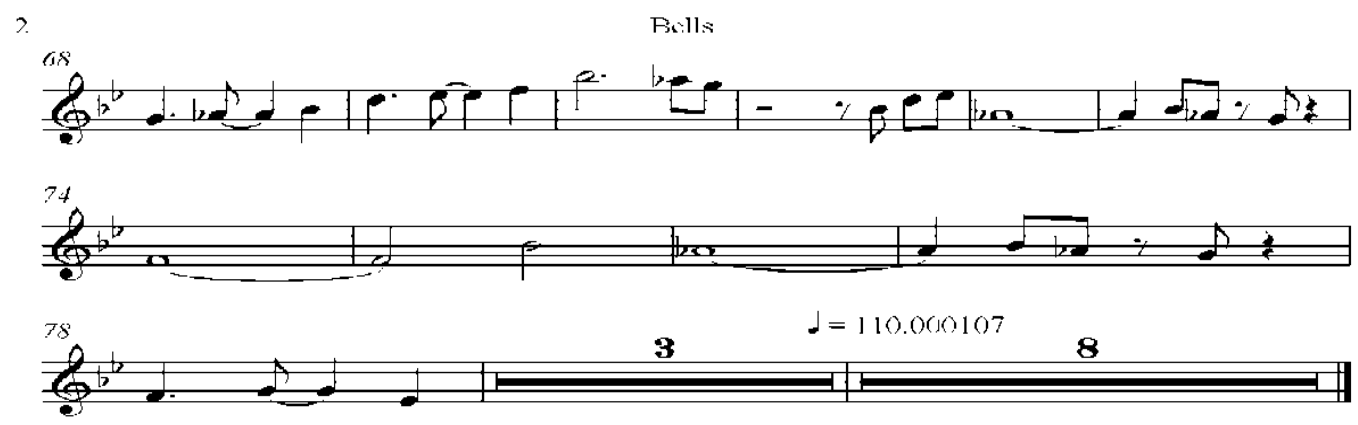

Part 9. Melodi lagu “Untukku” pada Bells

( Sumber : Suroso, 2016 )

\subsubsection{Xylophone}

Xylophoene dalam marching band merupakan bagian dari devisi perkusi atau masuk dalam kelompok perkusi. Alat musik tersebut dimainkan atau dibunyikan dengan cara dipukul, pemukul alat tersebut disebut mallet, xylophone sendiri terbuat dari bilahan kayu, bilahan tersebut mempunyai nada, bilahan yang panjang akan memiliki suara yang lebih rendah, sebaliknya dengan bilahan kayu yang pendek akan memiliki suara yang lebih tinggi.

Dalam lagu "Untuku” yang diaransemen xylophone sendiri memiliki fungsi sebagai pengisi suara agar lebih meriah dan sebagai penamis dalam lagu tersebut, notnot yang dimainkan sangat bervariatif, dari not $1 / 8$ hingga not $1 / 32$, untuk lebih jelas mengenai xylophone dalam aransemen tersebut dapat dilihat dalam part di bawah ini. 
Penjelasan yang dapat diberikan untuk part tersebut adalah seperti ini, xylophone dari intro lagu yaitu pada bar ke 1 sampai bar ke 7 tidak berbunyi atau diam, masuk lagu 1 yaitu bar ke 8 sampai pada bar ke 14 juga diam, xylophone mulai memainkan melodi pada bar ke 15 bersama alat musik bells sebagai jembatan menuju ke lagu 2 dengan melodi seperti ini : | $\mid \overline{\mathbf{1 1}} \overline{\mathbf{1 7 6 5}}$

Dalam part ke 15 tersebut tertulis dua nada yang langsung dimainkan dan nada yang dibunyikan adalah nada yang memiliki perbedaan satu oktaf, secara teknis untuk memainkan nada tersebut adalah dengan cara dipukul secara bersamaan dengan kedua tangan sesuai dengan nada yang tinggi dan nada yang rendah. Xylophone berbunyi dan memainkan nada pada bar ke 25 dengan not 1/8 dengan melodi sebagai berikut:

| $\overline{0 \text { 1/3 }} \overline{\mathbf{1 / 4} 1 / 3} \overline{01 / 3} \overline{1 / 4 ~ 1 / 3}$ |xylophone berbunyi melodi tersebut mulai bar ke 25 sampai dengan bar ke 33, maksud dari notasi tersebut adalah melodi yang dibunyikan langsung dua nada sekaligus yaitu nada do dengan nada mi, tanda birama yang dipakai dalam part tersebut yaitu 4/4. 
Xylophone

$\mathrm{C}^{2} \mathbf{1 4}$

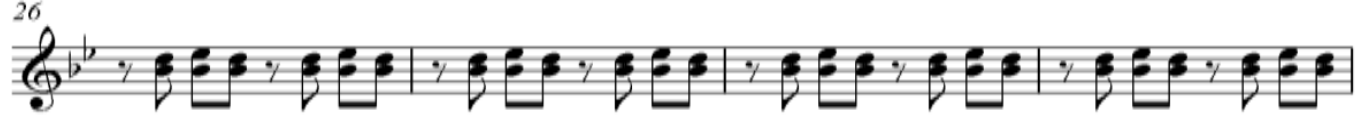

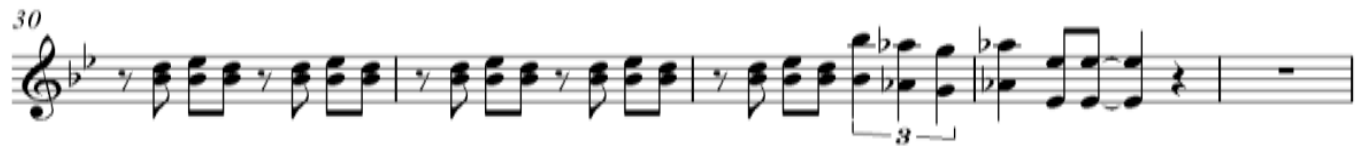

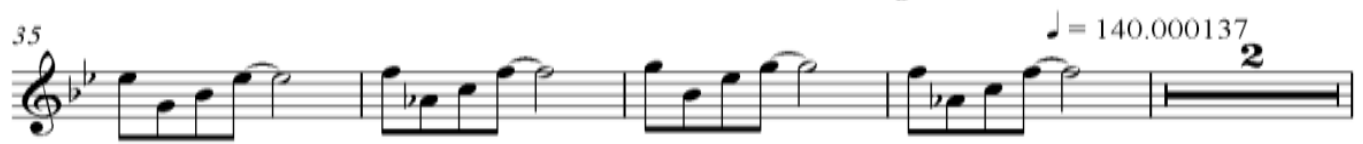

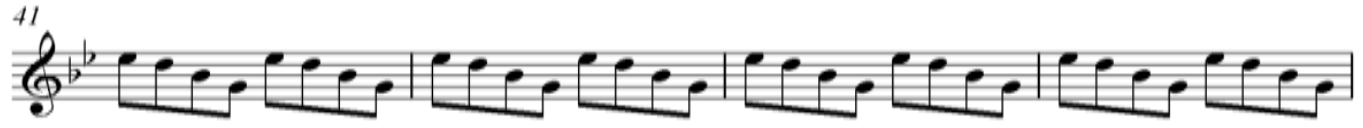

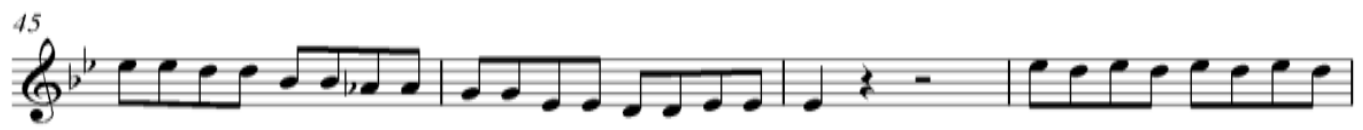

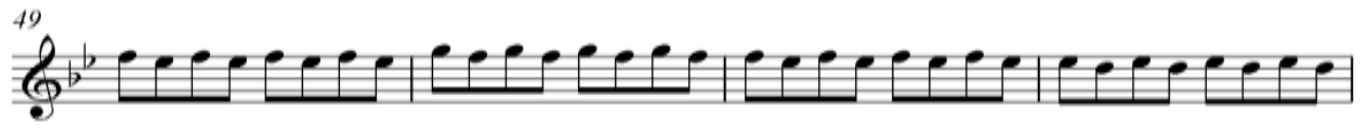

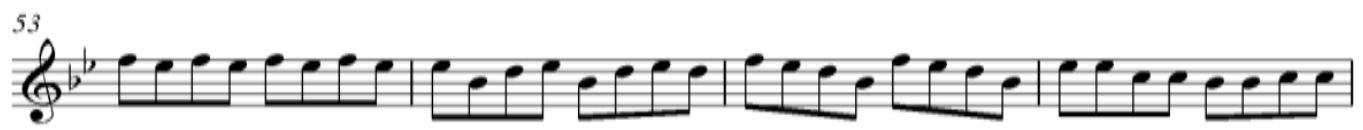

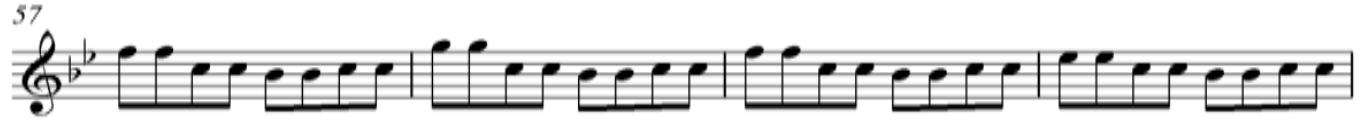

6)

2

Xylophone

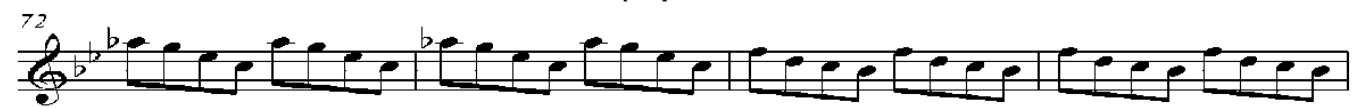

(10.0001078

Part 10. Melodi lagu “Untukku” pada Xylophone

( Sumber : Suroso, 2016 ) 


\subsubsection{Vibraphone}

Vibraphone merupakan alat musik perkusi yang bernada memainkan alat tersebut adalah dengan cara dipukul dengan pemukul atau yang sering disebut dengan mallet, alat musik tersebut terbuat dari bilahan logam dan dibawah bilahan tersebut terdapat pipa resonator yang berfungsi sebagai sustain sehingga menghasilkan vibrasi.

Vibraphone
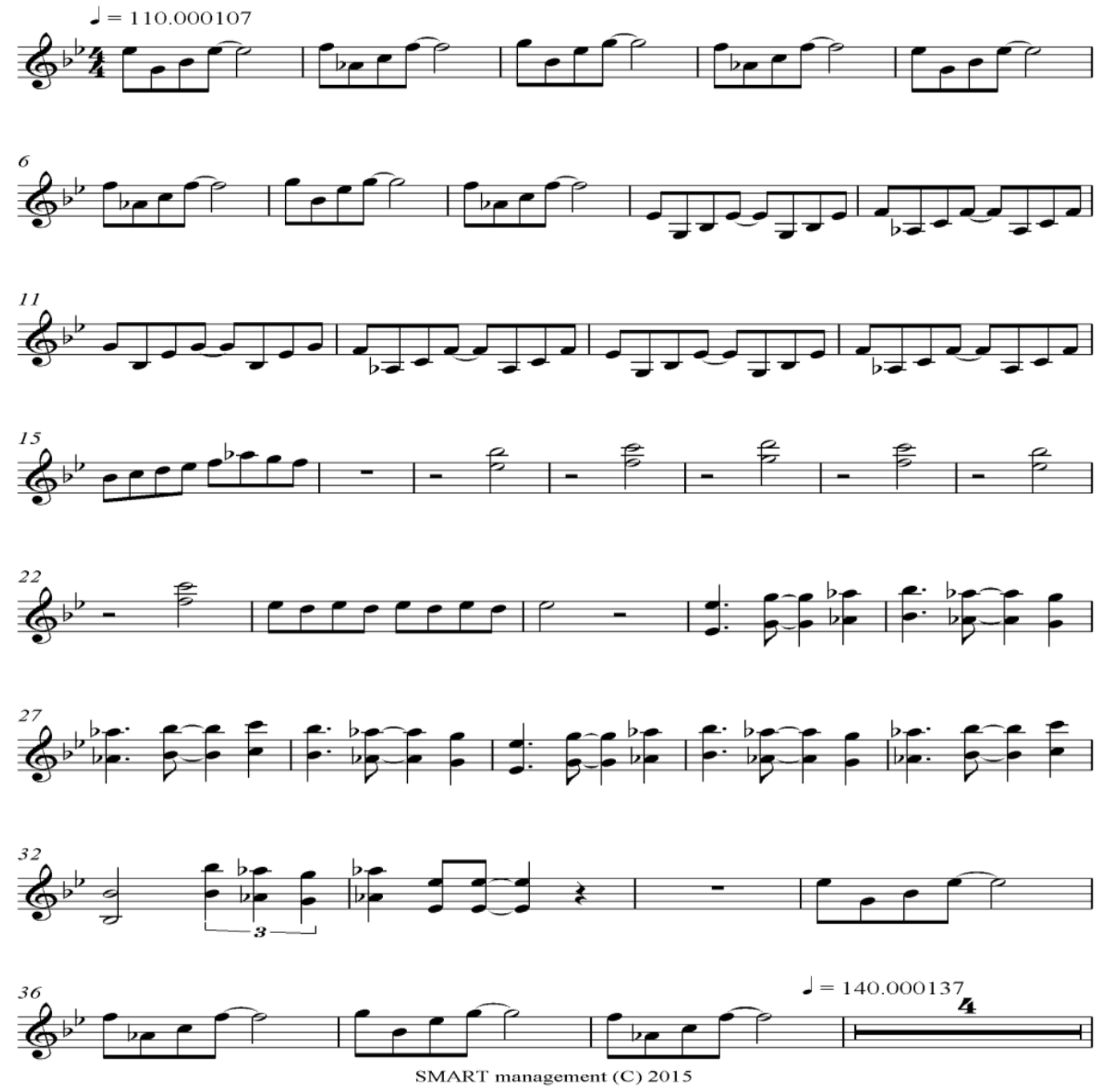

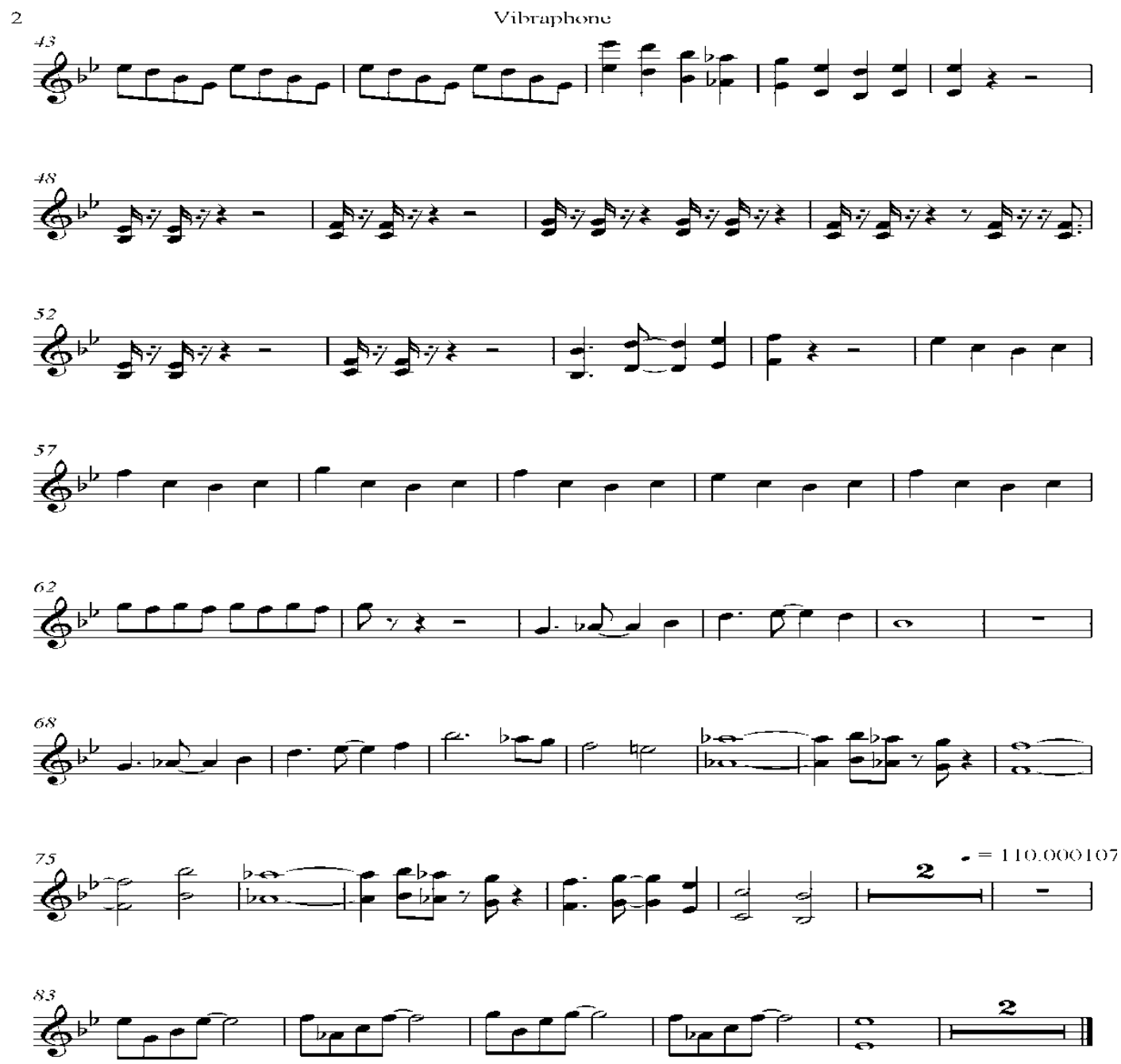

Part 11. Melodi lagu "Untukku” pada Vibraphone

( Sumber : Suroso, 2016 )

Vibraphone dalam part di atas menggunakan tangga nada $\mathrm{B}^{\mathrm{b}}$ atau $\mathrm{B}^{\mathrm{b}}=\mathrm{do}$, dengan urutan nada sebagai berikut $\mathrm{B}^{\mathrm{b}} \mathrm{C}$ D E $\mathrm{E}^{\mathrm{b}} \mathrm{F}$ G A B ${ }^{\mathrm{b}}$ ( do re mi fa sol la si do), meggunakan tanda birama 4/4 yang berarti dalam satu birama terdapat empat ketukan dengan tempo 110, dalam bar ke 40 atau bagian birama ke 40 terdapat pergantian tempo dengan tempo 140. 
Kedudukan vibraphone dalam aransemen ini adalah sebagai alat melodi dan sebagai penamis dalam aransemen lagu tersebut, vibraphone mulai memainkan sebuah melodi pada intro tepatnya pada bar ke satu sampai bar ke delapan dengan melodi sebagai berikut:

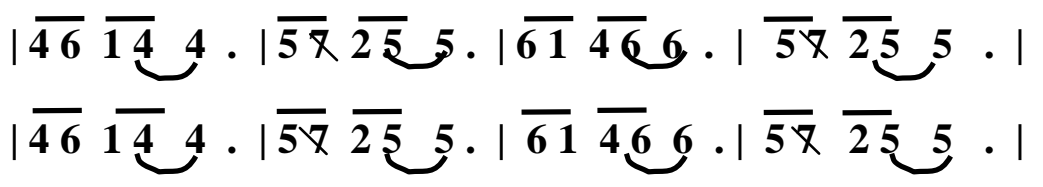

Pada bar selanjutnya dibagian bar sembilan sampai pada bar yang ke empat belas vibraphone masih memainkan melodi yang sama seperti di atas namun hanya turun satu oktaf ke bawah dan terdapat pengulangan meldoi dalam satu birama, menjadi melodi baru sebagai berikut:

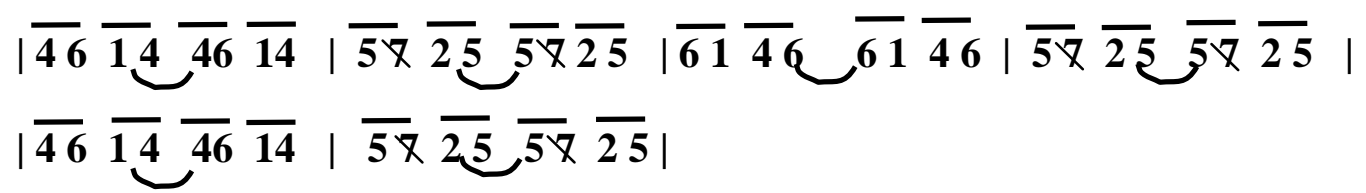

Berpindah pada bar ketujuh belas vibraphone memainkan nada dari unsur akor dengan memainkan dua nada dalam satu pukulan dengan nilai not $1 / 2$ dalam pergantian tempo vibraphone memainkan melodi pentatonis selama dua bar pada bar ke empat puluh tiga, yang dimaksud dengan pentatonis jawa secara harafiah "penta" berarti lima dan "tone" berarti nada atau suara.

\subsubsection{Akor yang digunakan dalam aransemen lagu untukku}

Sebuah aransemen musik tidak akan lepas dari sebuah akor, akor mempunyai peranan yang penting dalam aransemen yaitu sebagai pengiring lagu, pemberi suasana dalam lagu, dan sebagai pemerindah dari sebuah lagu. Akor tersendiri merupakan kumpulan dari tiga nada atau lebih yang memiliki tinggi dan rendah yang 
berbeda dimainkan secara bersamaan atau terputus-putus. Dalam aransemen lagu marching band, pemegang akor atau yang memainkan akor adalah pada brass section, dimana sie brass juga merupakan pemegang melodi, pada aransemen lagu marching band alat musik tuba, baritone. Pada aransemen lagu "Untukku" yang dipakai oleh Marching Band Domenico Savio yang memegang peranan dalam memainkan akor adalah tuba dan baritone dengan nada dari unsur akor. dapat dituliskan dalam aransemen lagu Untukku progresi akor yang dipakai sebagai berikut:

Nada dasar yang dipakai adalah $\mathrm{B}^{\mathrm{b}}=\mathrm{Do}$

$$
\begin{gathered}
\text { Intro : } E^{\mathrm{b}} \ldots|\mathrm{Fm} \ldots| \mathrm{Gm} \ldots|\mathrm{Fm} \ldots| 2 \mathrm{x} \\
\text { Lagu : } \mathrm{E}^{\mathrm{b}} \ldots|\mathrm{Fm} \ldots| \mathrm{Gm} \ldots|\mathrm{Fm} \ldots| \\
E^{\mathrm{b}} \ldots|\mathrm{Fm} \ldots| \mathrm{B}^{\mathrm{b}} \ldots \mid \\
E^{\mathrm{b}} \ldots|\mathrm{Fm} \ldots| \mathrm{Gm} \ldots|\mathrm{Fm} \ldots| \\
E^{\mathrm{b}} \ldots|\mathrm{Fm} \ldots| \mathrm{E}^{\mathrm{b}} \ldots \mid
\end{gathered}
$$

Reff : $E^{b} \ldots|G m \ldots| G^{\#} M \ldots\left|B^{b} \ldots\right|$

$$
\begin{aligned}
& E^{b} \ldots|G m \ldots| G^{\#} M \ldots\left|B^{b} \ldots\right| \\
& E^{b} \ldots \mid \text { Fm } \ldots|G M \ldots| \text { Fm } \ldots \mid
\end{aligned}
$$




\subsubsection{Baritone}

Alat musik marching band pada umumnya memiliki dua jenis yaitu peralatan melodis dan ritmis, di dalam peralatan melodis biasanya terdiri dari alat tiup dan alat perkusi bernada. Sedangkan alat musik akor di marching band kebanyakan dipegang oleh alat musik tiup yang memiliki karakter suara bass yaitu tuba, euphonium dan baritone serta di selingi alat musik tiup lainnya yang bertujuan untuk mempertegas dari sebuah akor.

Baritone adalah alat musik tiup keluarga logam yang mempunyai karakter suara bass dan lembut bulat. Dalam marching band baritone merupakan alat musik yang sering memainkan nada akor dengan meniup dengan long tone (nada panjang) ataupun dengan cara terpatah-patah yang berguna untuk mengiringi sebuah akor, walaupun terkadang baritone juga memainkan sebuah melodi, nada dasar yang digunakan baritone secara umum adalah nada dasar $\mathrm{B}^{\mathrm{b}}$,

Part baritone pada aransemen lagu "Untukku" yang digunakan Marching Band Domenico Savio Semarang dapat dilihat di bawah bertangga nada $\mathrm{B}^{\mathrm{b}}$ tanda birama 4/4 dengan tempo 110. Nada yang dimainkan oleh baritone dalam part di bawah kebanyakan adalah nada yang merupakan unsur dari akor dengan meniup nada-nada yang panjang, baritone meniupkan nada mulai pada bar ke lima dengan nada seperti berikut : $1 \ldots|2 \ldots| \mathbf{3} \ldots|\mathbf{2} \ldots| \mathbf{4} \mathbf{x}$ 
Nada yang dimainkan oleh baritone merupakan unsur nada dari akor, saat meniup nada do merupakan unsur dari akor satu yang terdiri dari nada (do re mi), sedangkan pada saat meniup nada re merupakan usnur dari akor lima (re sol si), saat meniup nada mi merupakan unsur dari akor enam (do, mi, la) yang nantinya akan digabung dengan alat musik tiup lainnya, khususnya adalah alat tiup low brass atau alat musik yang memiliki karakter bass. Namun pada bar ke lima puluh enam sampai dengan bar enam puluh satu, nada yang ditiup menggunakan teknik stacato atau terputus-putus dengan tempo 140, yang menjadikan suasana yang ada pada bar tersebut menjadi riang dan.

Dalam part di bawah, baritone sesekali memainkan melodi dari bagian lagu "Untukku" yaitu pada bar ke dua puluh empat sampai pada bar ke dua puluh enam dengan melodi sebagai berikut :

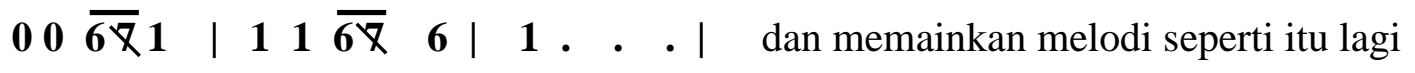
pada bar ke empat puluh tujuh sampai pada bar ke limah puluh tiga dengan melodi seperti di bawah. 
Baritone

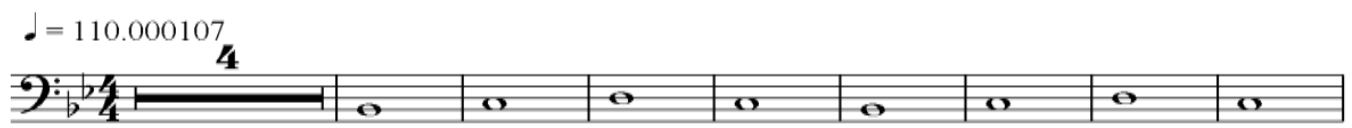

13
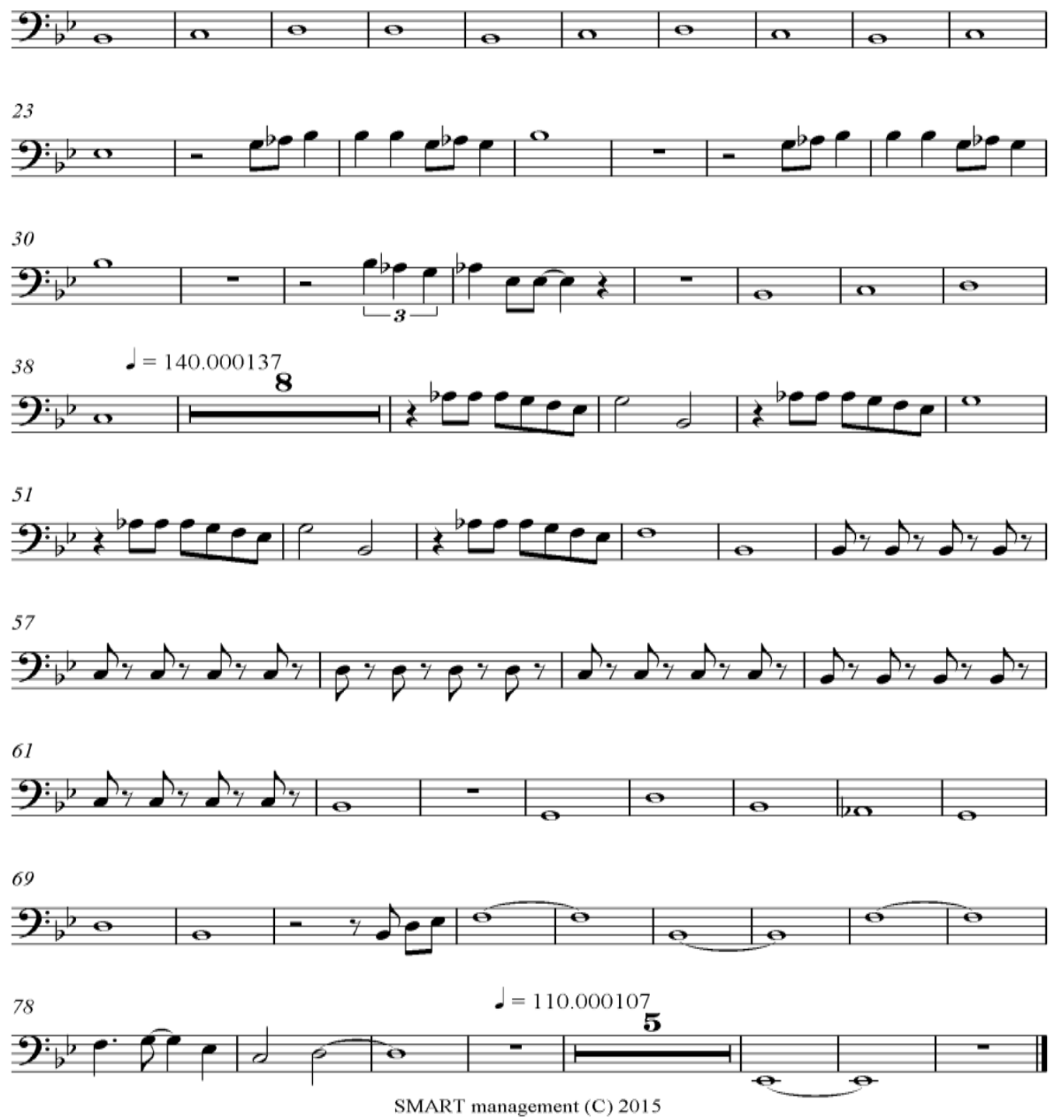

Part 12. Akor "Untukku" pada Baritone

( Sumber : Suroso, 2016 ) 


\subsubsection{Tuba}

Alat musik tuba merupakan alat musik tiup logam, merupakan alat musik yang penting dalam brass line, sebab alat musik tersebut sebagai pemegang akor bersama baritone atau pun trombon yang termasuk alat musik low brass, dan terkadang mellophone atau trumpet ikut membantu dalam membentuk akor. Alat musik ini berukuran sangat besar dibanding dengan alat musik tiup yang lainnya. Nada dasar yang digunakan oleh alat tuba pada umumnya menggunakan nada dasar $\mathrm{B}^{\mathrm{b}}$ atau do $=\mathrm{B}^{\mathrm{b}}$, dengan urutan nadanya sebagai berikut : $\mathrm{B}^{\mathrm{b}} \mathrm{C} \mathrm{DE}^{\mathrm{b}} \mathrm{F} \mathrm{G} \mathrm{A} \mathrm{B} \mathrm{B}^{\mathrm{b}}$ ( do re mi fa sol la si do).

Dalam aransemen lagu "Untukku" tuba seperti hanya dengan baritone namun tuba lebih banyak memegang akor dengan memainkan nada-nada panjang long tone dengan hitungan 4 ketuk dengan tujuan untuk mengiringi sebuah lagu menggunakan nada dari sebuah unsur akor, untuk lebih jelas dapat dilihat sebagai berikut:

Tuba dalam part di bawah dapat terlihat banyak sekali memainkan nada panjang atau long tone yang bertujuan untuk mengiringi jalannya sebuah melodi dalam lagu, dimana nada tersebut merupakan bagian nada dari akor, dan nada tersebut akan menjadi sebuah akor apabila ditiup bersama dengan alat musik low brass yang laninnya. Dari partitur di atas dapat dijelaskan bahwa tuba memainkan nada atau berbunyi pada bar ke 1 sampai akhir atau dapat dikatakan bahwa tuba bermain dari intro sampai coda dengan sedikit diam. Nada yang dibunyikan tuba pada awal sampai akhir merupakan nada dari unsur akor seperti nada seperti ini: $\mid \mathbf{4}$. . . | $5 \ldots|6 \ldots| 4 \ldots \mid 3 X$ 
Tuba
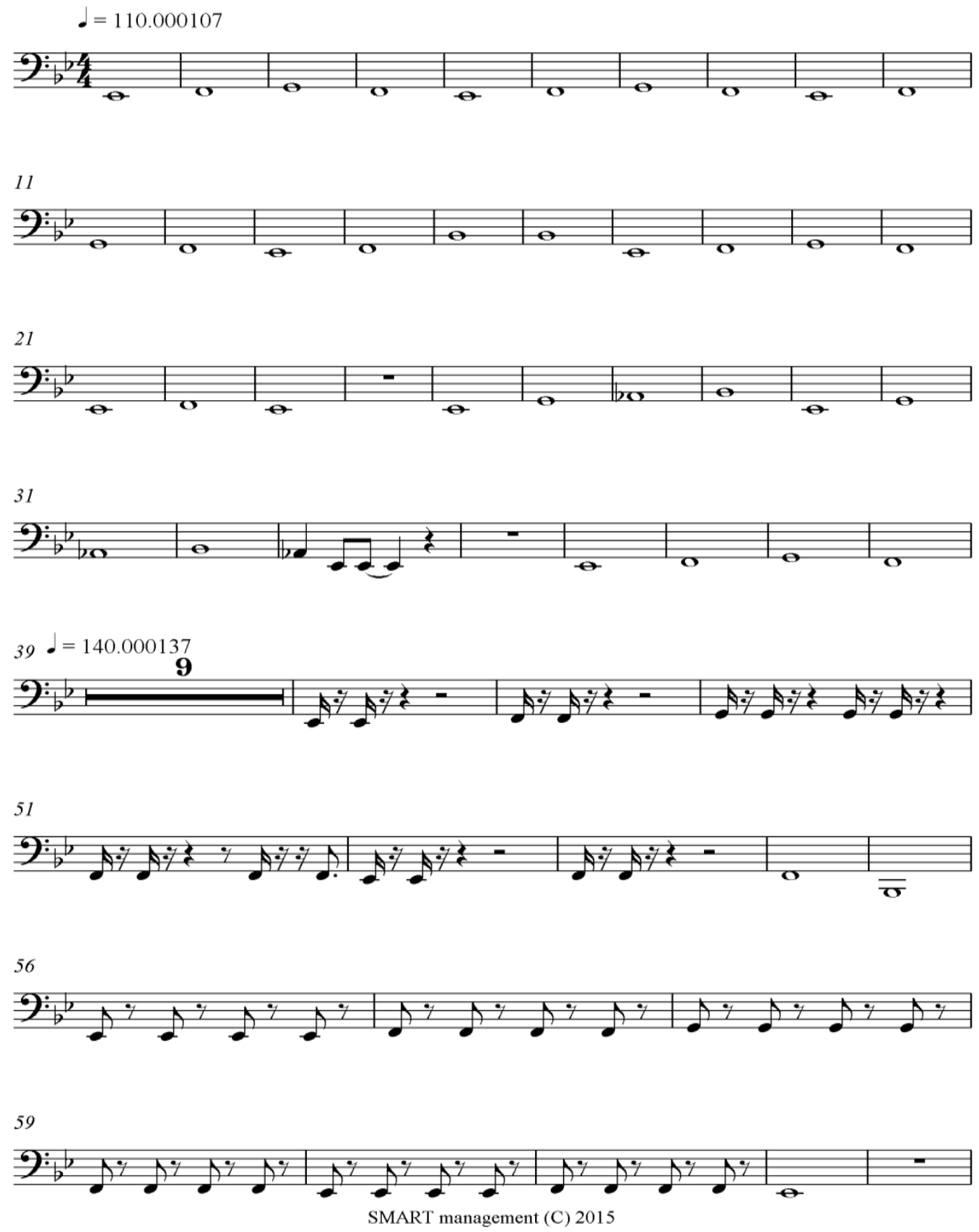

Part 13. Akor lagu "Untukku” pada Tuba

( Sumber : Suroso, 2016 ) 


\subsection{Manajemen Marching Band Domenico Savio Semarang}

Sebuah organisasi dapat berjalan dengan baik apabila pemimpin dapat mengatur anak buah dengan menerapkan langka-langkah manajemen yang meliputi perencanaan, pengorganisasian, penggerakan, dan pengawasan atau evaluasi. Marching Band Domenico Savio dalam menajemennya mengacu pada langkahlangkah dasar manajemen secara umum yaitu perencanaan, pengorganisasian, penggerakan, dan pengawasan.

\subsubsection{Perencanaan (planning)}

Pengelolaan organisasi tidak lepas dari perencanaan sebelum melanjutkan ke tahap atau langkah selanjutnya yaitu pengorganisasian, penggerakan, dan pengawasan, supaya tujuan yang direncanakan dapat tercapai dengan baik maka diperlukan rencana atau plannig.

Demikian juga dengan Marching Band Domenico Savio, melalui perencanaan dapat memberikan suatu gambaran serta arah selanjutnya untuk mengambil langkah yang jelas. Mas Suroso (wawancara, Maret 2016) atau yang lebih dikenal dengan sebutan Kak Roso adalah kepala pelatih atau Band Directer Marching Band Domenico Savio mengatakan bahwa Marching Band Domenico Savio adalah sarana yang disediakan oleh sekolah melalui kegiatan ekrakurikuler yang di dalamnya terdapat bidang seni juga olahraga yang dapat melatih siswa untuk berdisiplin, melatih mental, kenamdirian, kepemimpinan, dan prestasi bagi sekolah. 
Dalam sejarah Marching Band Domenico Savio, marching band tersebut telah vakum selama delapan belas tahun dari perlombaan, alumni ingin membangkitkan marching band tersebut supaya dapat berprestasi dan berkembang lagi. Kemudian mereka menghubungi pembina pada saat itu dan masih sampai saat ini yaitu Maria Yosefa Mariatmi atau yang lebih dikenal dengan panggilan Bu Mar, supaya Marching Band Domenico Savio bisa kembali bangkit, hal tersebut kemudian direspon dengan positif dan mereka mengajukan gagasan kepada sekolah, akhirnya gagasan tersebut disetujui.

Menurut Katty (wawancara 25 Maret 2016) selaku alumni mengungkapkan, hal pertama yang dilakukan oleh pembina, alumni, dan kepala pelatih adalah menentukan sebuah target, setelah menentukan target disepakati secara bersama, target Marching Band Domenico Savio adalah mengikuti perlombaan Hamengkubuwono Cup 2015. Untuk menunjang target tersebut diadakanlah rencana, dikutip penulis dari kepala pelatih Marching Band Domenico Savio Semarang, rencana tersebut meliupti:

\subsubsection{Perekrutan}

Perekrutan merupakan tahap untuk mencari sumber daya atau peserta dilakukan untuk mencari para anggota marching band, karena pada saat itu Marching Band Domenico Savio baru di aktifkan kembali setelah vakum selama delapan belas tahun dan belum mempunyai anggota yang tetap. Perekrutan tersebut untuk mendapatkan pemain brass, perkusi, dan colour guard / pemain bendera. 


\subsubsection{Penentuan Tema}

Penentuan tema atau konsep dari sebuah pertunjukan merupakan hal yang penting, supaya pertujukan dapat dinikmati dan dipahmi. Tema yang diambil atau digunakan oleh Marching Band Domenico Savio Semarang adalah "Tribute Of Chrisye" tema tersebut ternyata ditentukan oleh tim pelatih dikarenakan, ini merupakan hal pertama untuk Marching Band Domenico Savio dalam mengikuti perlombaan sehingga pengambilan keputusan penentuan tema diberikan kepada tim pelatih.

\subsubsection{Program}

Dalam program kerja Marching Band Domenico Savio terdapat beberapa kegiatan yang bertujuan untuk mencapai sebuah target, diantaranya adalah :

(1) Menentukan Jadwal Latihan

Tabel 3. Jadwal Latihan Marching Domenico Savio Semarang

\begin{tabular}{|l|c|c|}
\hline \multicolumn{1}{|c|}{ Hari } & Waktu & Tempat \\
\hline Senin & $13.00-16.00$ & SMP Pangudi Luhur Domenico Savio \\
& & Semarang \\
\hline Rabu & $13.00-16.00$ & SMP Pangudi Luhur Domenico Savio \\
& & Semarang \\
\hline
\end{tabular}

( Sumber : SMP Pangudi Luhur Domenico Savio Semarang, 2016 )

Adapun jadwal latihan yang sudah disusun merupakan hasil dari kesepakatan antara pihak sekolah dengan pihak tim pelatih. Hal ini disesuaikan juga dengan 
jadwal mengajar pelatih karena pelatih tidak hanya melatih di Marching Band Domenico Savio.

(2) Pendidikan Dasar

Proses setelah anggota baru diterima, anggota baru wajib mengikuti pendidikan dasar yang meliputi: (1) pengenalan alat musik marching band baik dari perkusi seperti snare drum, bass drum, quart tom, cymball, dari brass trompet, baritone, mellophone, tuba. Dalam tahap pengenalan ini memiliki tujuan menyeleksi bakat anggota dan melihat minat peserta terhadap alat musik yang ingin dipelajari sehingga dapat mempermudah dalam pembagian pemegang alat. (2) pendidikan baris-berbaris atau yang sering disebut oleh kalangan anak marching dengan sebutan drill yang memiliki fungsi sebagai acuan gerak kaki supaya kompak dalam aksi unjuk gelar, baris-berbaris pada umumnya digunakan untuk aksi unjuk gelar yang meliputi jalan ditempat, langkah tegap, langkah biasa, hadap kanan, hadap kiri, balik kanan, serong kanan, serong kiri.

(3) Materi Latihan Dasar

Perencanaan materi meliputi tentang materi latihan, yang meliputi tentang aransemen lagu yang akan dibawakan dan materi latihan dasar dan latihan inti. Aransemen yang dibawakan oleh Marching Band Domenico Savio Semarang merupakan aransemen yang prosesnya atau pembuatannya diluar sumber daya sekolah tersebut, latihan dasar dalam materi yang diberikan adalah sebagai berikut: 1.) Latihan dasar drill atau gerak berjalan, 2.) Latihan dasar sticking, 3.) Latihan dasar 
breathing untuk divisi brass, 4.) Latihan dasar memegang mallet untuk pitch, 5.) latihan dasar koreo untuk pemain bendera.

\subsubsection{Pengorganisasian}

Pengorganisasian diartikan sebagai keseluruhan proses pengelompokan orangorang, alat, tugas, dan tanggung jawab (wewenang) sedemikian rupa sehingga tercipta suatu organisasi yang dapat digerakan menjadi satu kesatuan kerja sama untuk mencapai tujuan ( Jazuli $2014: 13$ ).

Marching Band Domenico Savio Semarang mempunyai organisasi dibawah naungan Yasyasan Pangudi Luhur Semarang, sehingga untuk hirarki atau struktur kepengurusan sangatlah diharapkan kesungguhannya sehingga dapat melaksanakan tugas-tugas dalam kepengurusan, jadwal latihan, pendanaan, keuangan, pengondisian alat, dan lain sebagainya.

Pembina Marching Band Domenico Savio Semarang ibu Maria Yosefta Mariatmi mengatakan, bahwa dalam sistem kepengurusan Marching Band Domenico Savio Semarang pihak dari luar sekolahpun dilibatkan untuk ikut serta dalam sistem kepengurusan, supaya selain untuk mendukung anaknya dalam mengikuti ekstrakurikuler dari keikutsertaan orangtua akan menimbulkan rasa memiliki terhadap Marching Band Domenico Savio Semarang (wawancara, Maret 2016).

Di dalam sistem kepengurusan Marching Band Domenico Savio Semarang terdapat struktur oraganisasi yang melibatkan pihak luar yaitu orang tua siswa dan alumni dari sekolah tersebut untuk ikut serta dalam mengelola Marching Band Domenico Savio dengan tugas yang berbeda-beda yang menjadikan kokoh. Pihak luar 
dalam hal ini memberikan kontribusi yang sangat penting, adapun tanggung jawab adalah sebagai berikut ketua Marching Band Domenico Savio yang diketuai oleh perwakilan orang tua siswa bertanggung jawab kepada pihak sekolah melalui pembina. Pembina yang merupakan perwakilan guru mata pelajaran yang ditunjuk oleh sekolah bertanggung jawab kepada koordinator ekstrakurikuler dan koordinator ekstrakurikuler yang merupakan perwakilan guru mata yang ditunjuk oleh sekolah bertanggung jawab kepada kepala sekolah sebagai pelindung.

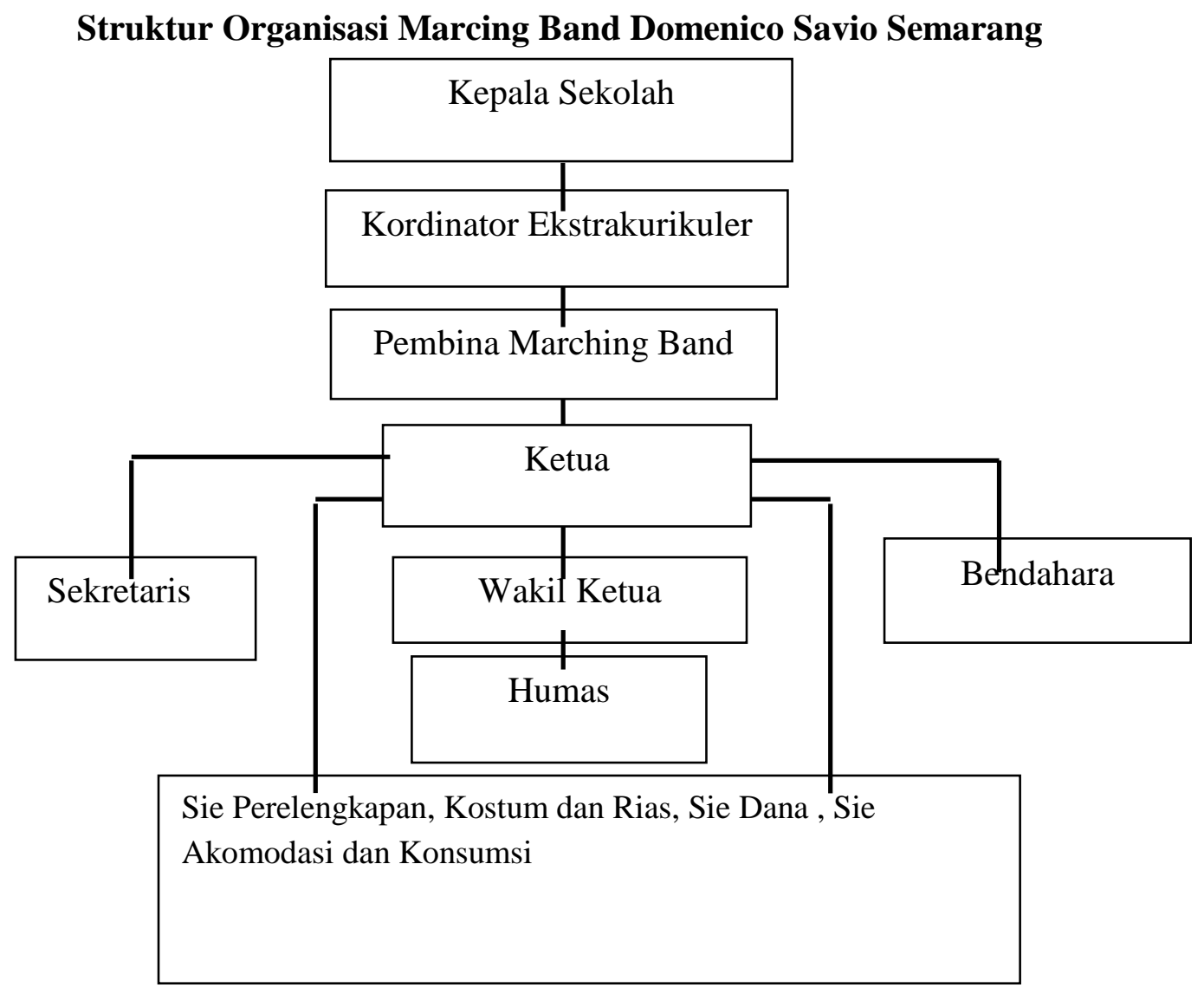

Bagan 5. Struktur Organisasi Marching Band Domenico Savio ( Sumber : SMP Pangudi Luhur Domenico Savio Semarang, 2016 ) 
Keterangan :

Setiap organisasi mempunyai perangkat untuk anggotanya dalam melaksanakan tugas, tugas-tugas atau fungsi-fungsi dari pengurus dari pihak sekolah adalah:

\subsubsection{Kepala Sekolah}

Kepala dalam organisasi tersebut bukanlah sebagai ketua umum akan tetapi sebagai pelindung, dengan tugas sebagai berikut:

1. Melindungi organisasi dan sebagai penanggung jawab, dalam hal tersebut segala sesuatu yang terjadi dalam oraganisasi Marching Band Domenico Savio yang menjadi pelindung adalah kepla sekolah.

2. Menetapkan kebijakan yang telah disiapkan pengurus dengan maksud yaitu bahwa apabila pengurus membuat rencana, harus mengonfirmasi dengan kepala sekolah agar dapat ditinjau kembali oleh kepala sekolah.

\subsubsection{Kordinator Ekstrakurikuler}

SMP Pangudi Luhur Domenico Savio Semarang memiliki beberapa ektrakurikuler yang cukup banyak, untuk mengatatsi hal tersebut oleh pihak sekolah seorang guru untuk mengelola ekstrakurikuler, dengan tugas sebagai berikut:

1. Membagi dan memilih pembina ekstrakurikuler, dalam membagi tugas tersebut kordinator ekstrakurikuler akan menunjuk perwakilan guru melalui musyawarah dengan kepala sekolah dan guru yang bersangkutan.

2. Mengkoordinasikan kegiatan ekstrakurikuler antara yang satu dengan yang lainnya, tugas tersebut dilakukan dengan mengatur jadwal antara 
ekstrakurikuler yang satu dengan yang lainnya supaya tempat latihan tidak berebutan

\subsubsection{Pembina}

Pengangkatan pembina dilakukan melalui rapat antra guru-guru bersama kepala sekolah, dengan sistem penujukan, dengan tugas sebagai berikut:

1. Mengatur jalannya ekstrakurikuler dan menentukan jadwal latihan, tugas tersebut dilakukan melalui musyawarah antara pembina esktrakurikuler yang lain serta kordinator ekstrakurikuler.

2. Mendampingi dan memberi arahan terhadap kegitan ekstrakurikuler, tugas tersebut dilakukan dengan cara memberi motivasi-motivasi kepada peserta Marching Band Domenico Savio Semarang, dan memeberi masukanmasukan kepada kepengurusan yang ada.

3. Menetapkan kebijakan terkait kepengurusan dalam ekstrakurikuler, tugas tersebut bersangkutan dengan keputusan yang akan diberikan terhadap suatu masalah.

\subsubsection{Ketua}

Ketua pengurus di angkat melalui rapat bersama pihak sekolah, pihak komite, dan pihak orang tua murid, yang menjadi ketua tersebut merupakan perwakilan dari pihak orang tua murid, ketua memiliki tugas sebagai berikut:

1. Mempimpin organisasi dengan baik, maksud dari tugas tersebut adalah bahwa ketua bertanggung jawab atas berlangsungnya kepengurusan kepada pembina Marching Band Domenico Savio Semarang. 
2. Menetapkan kebijakan yang telah dirapatkan, maksud tugas tersebut adalah bahwa dalam sebuah rapat kepengurusan, ketuan berhak memberi keputusan.

3. Mengevaluasi jalannya kepengurusan, tugas tersebut dilakukan dengan mengawasi kepengurusan atas berlangsungnya tugas-tugas seksi yang lain.

\subsubsection{Wakil Ketua}

Wakil ketua diangkat melalui rapat bersama pembina, komite, dan orang tau murid, dengan tugas sebagai berikut:

1. Mengordinasi semua sie atau seksi, dalam tugas ini wakil ketua sebagai pengatur dari berjalannya tugas dari per seksi yang telah ditetapkan melalui rapat bersama serta membagi tugas sesuai potensi.

2. Menetapkan kebijakan bersama ketua, tugas lain dari wakil dari ketua selain mengordinasi para seksi, wakil ketua pun juga ikut serta dalam menetapkan sebuah keputusan bersama ketua.

\subsubsection{Sekretaris}

Penujukan sekretaris merupakan hak dari ketua dan wakil ketua melalui rapat, dengan tugas sebagai berikut:

1. Menyimpan data-data dan menyimpan arsip, tugas tersebut dilakukan dengan cara menyimpan surat-surat yang telah dibuat, guna sebagai cadangan apabila surat tersebut diperlukan kembali. 
2. Sebagai notulen dalam setiap rapat, tugas tersebut dilakukan dengan cara mencatat semua hal yang penting dalam rapat yang akan disampaikan pada akhir rapat.

3. Menyiapkan surat laporan dan hasil evaluasi kegiatan, dalam tugas tersebut sekretaris bertugas membuat laporan yang diberikan oleh setiap sie yang telah melaksanakan tugas untuk dilaporkan pada saat rapat pengurus berlangsung.

\subsubsection{Bendahara}

Penujukan atau pengangkatan bendahara merupakan hak dari ketua dan wakil melalui rapat, dengan tugas sebagai berikut:

1. Mendata pengeluaran dan pemasukan keuangan, tugas tersebut dilakukan dengan cara mencatat semua pengeluaran dari kepengurusan dan mencatat semua pemasukan keuangan supaya dapat dipantau oleh semua anggota kepengurusan.

2. Membuat tanda bukti transaksi, tugas tersebut dilakukan dengan cara membuat tanda bukti yaitu melalui kwittansi.

3. Menyiapkan hasil laporan keuangan, dalam tugas tersebut bendahara akan memberikan laporan terkait pengeluaran yang digunakan dalam setiap pengeluaran yang digunakan oleh kepengurusan.

\subsubsection{Humas}

Pengangkatan humas adalah hak dari ketua dan wakil ketua melaui rapat, dengan tugas sebagai berikut : 
1. Pembuplikasian Marching Band Domenico Savio Semrang, tugas tersebut dengan cara menyampaikan pesan kepada sekolah dan pihak lain, tugas tersebut dilakukan dengan cara memberi informasi tentang agenda yang akan dilakukan kepada pihak sekolah, serta pencari informasi mengenai jadwal lomba yang akan diikuti.

\subsubsection{Sie Perlengkapan}

Sie merupakan pembantu kepengurusan, pengangkatan tersebut melalui rapat orang tua murid, dan pengurus yang telah terbentuk, dengan tugas sebagai berikut:

1. Bertanggung jawab kepada kepengurusan, dengan melakukan tugas sesuai kemampuan dan segala rencana yang telah disipakan haruslah dikerjakan dengan tepat waktu.

2. Mempersiapakan perlatan untuk marching band, tugas tersebut dilakukan dengan mengecek peralatan marching band dalam satu minggu sekali, apak terdapat kerusakan apakah tidak.

3. Mempersiapakan perlengkapan dalam menunjang perlombaan, tugas yang dilakukan adalah mempersiapkan peralatan yang akan digunakan untuk lomba serta bertanggung jawab atas kelengkapan alat dilapangan.

\subsubsection{Sie Kostum dan Rias}

Sie kostum dan rias dalam pengangkatan melalui rapat kepengurusan, dengan tugas sebagai berikut:

1. Bertanggung jawab kepada kepengurusan, tugas yang dilakukan harus sesuai dengan apa yang direncanakan dalam kepengurusan. 
2. Mempersiakapan kostum dan rias, tugas dari seksi kostmu dan rias adalah dengan mempersiapankan kostum sebelum lomba dilakukan dan merias peserta Marching Band Domenico Savio Semarang pada saat akan melakukan lomba.

\subsubsection{Sie Dana}

Sie dana dalam pengangkatan melalui rapat kepengurusan, dengan tugas sebagai berikut:

1. Mencari dana, tugas dari seksi ini adalah mencari dana untuk menunjang dalam perlombaan, melalui penggalangan dana dari orang tua yang dilakukan seminggu sekali, membagi proposal pendanaan, dan menjula produk seperti kaos, gantungan kunci, makanan. Semua hasil dari keuntungan teresebut akan dimaksukan kedalam kas kepengurusan yang nantinya dipakai dalam akomodasi dan perlengkapan dalam mengikuti perlombaan.

\subsubsection{Sie P3K}

Sie P3k atau pertolongan pertama pada kecelakaan, diangkat melalui rapat kepengurusan eksternal, dengan tugas sebagai berikut:

1. Memberi pertolongan pada kecelakaan, tugas dari seksi ini adalah pada saat menjelang perlombaan dan pada saat perlombaan, dengan memeberi pertolongan kepada peserta Marching Band Domenico Savio Semarang yang mengalami cedera.

2. Mengordinasi tenaga medis, tugas tersebut dilakukan dengan cara menghubungi tenaga medis supaya dapat ikut selama perlombaan dengan 
tujuan apabila terjadi kecelakaan dan cedera yang serius, peserta dapat ditangani oleh orang yang lebih tepat.

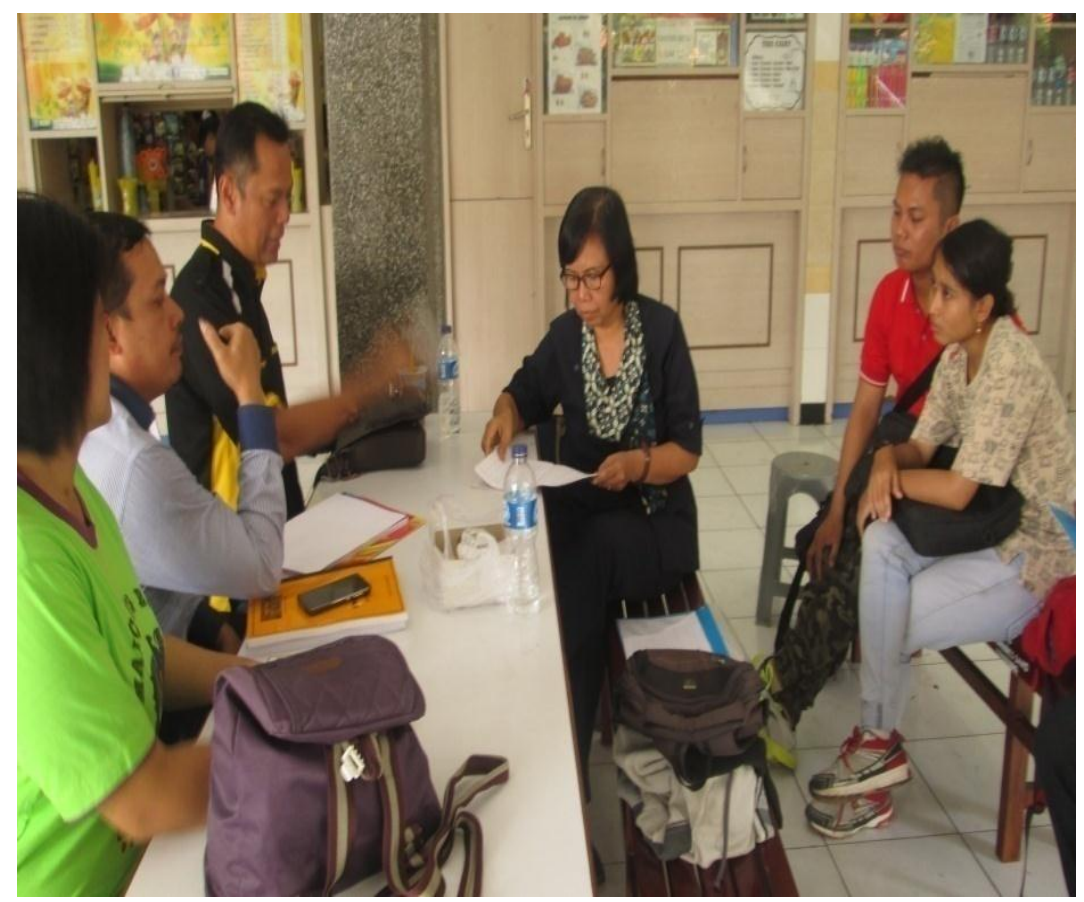

Gambar 2. Rapat Pengurus

( Sumber : Wibawa, 2016 )

Dari gambar di atas menunjukan pihak kepengurusan Marching Band Domenico Savio dan pelatih sedang rapat, rapat tersebut membicarakan tentang keanggotaan atau peserta yang ikut dalam Marching Band Domenico Savio.

\subsubsection{Penggerakkan}

Setelah perencanaan dan pengorganisasian langkah selanjutnya adalah tahap penggerakan. Penggerakan dalam ( Jazuli 16 : 2014) menyebutkan bahwa penggerakan menyangkut tindakan-tindakan yang menyebabkan suatu organisasi bisa 
berjalan ke arah sasaran perencanaan. Dalam tahap ini seorang manajer diperlukan dalam memimpin sebuah organisasi dengan motivasi-motivasi agar terjalin sinergi yang baik antara satu dengan yang lainnya.

Fungsi acctuating atau menggerakan meliputi kegiatan-kegiatan yang diperlukan untuk jabatan-jabatan yang ada dalam struktur organisasi. Untuk itu diperlukan pedoman dan instruksi yag tegas pada bawahan supaya pekerjaan dapat dilaksanakan sesuai dengan tujuan. Tujuan instruksi atau pemberian perintah oleh atasan kepada bawahan adalah untuk mengordinir kegiatan bawahan, agar kegiatan masing-masing bawahan terkordinir kepada satu arah, yaitu tujuan.

Dalam menggerakan di Marching Band Domenico Savio Semarang, tujuan yang diharapkan adalah untuk tujuan sekolah atau instansi yaitu meraih sebuah prestasi semaksimal mungkin. Adapun tahapan dalam penggerakan di Marching Band Domenico Savio, adalah sebagai berikut.

\subsubsection{Perekrutan}

Perekrutan atau penerimaan anggota baru merupakan tanggung jawab pengurus dan pelatih, penerimaan anggota dilakukan di bulan September 2015. Peserta baru difokuskan pada siswa-siswi kelas VII dengan mengisi lembar formulir yang berisikan nama, tempat tanggal lahir, kelas, dan alamat. Peserta juga wajib memberikan surat pernyataan yang menyatakan siap mengikuti kegiatan latihan dan lomba dengan konsekuensi yang ada, ditanda tangani oleh diri sendiri dan orang tua. Menurut Kak Roso mengatakan Perekrutan merupakan tahap untuk mencari sumber daya atau peserta, dilakukan untuk mencari para anggota marching band. Dalam 
tahap perekrutan tersebut tahapnya adalah dengan membagi formulir yang disediakan oleh sekolah kepada siswa, dan rencananya adalah merekrut siswa dengan jumlah menyesuaikan alat yaitu 87 alat.

Dalam perekrtutan tersebut akan diambil siswa untuk memainkan 20 trumpet, 6 mellophone, 12 baritone, 2 tuba, 4 snare drum, 4 bass drum, 2 quartom, 4 cymbals, 2 xylophone, 8 bells, 3 mayor, 20 pemain bendera. Pada tahap perekrutan tersebut akan diadakan selama satu bulan, pada minggu pertama peserta yang mendaftar akan dikenalkan terlebih dahulu peralatan marching band supaya tertarik, pada minggu kedua peserta diwajibkan memilih peralatan dan dilanjutkan dengan latihan dasar alat sampai pada minggu ke empat, setelah itu memasuki bulan kedua peserta akan disekelsi (wawancara, Maret 2016).

\subsubsection{Penentuan Tema}

Penentuan tema atau konsep dari sebuah pertunjukan merupakan hal yang penting, supaya pertunjukan dapat dinikmati dan dipahmi. Menurut Kak Roso mengaktakan bahwa tema yang diambil atau digunakan oleh Marching Band Domenico Savio Semarang adalah "Tribute Of Chrisye" tema tersebut diambil untuk ajang perlombaan dengan makasud agar penonton lebih mudah memahami konsep yang dibawakan oleh Marching Band Domenico Savio Semarang.

Serta tujuan lainnya adalah dengan tema "Tribute Of Chrisye" supaya perseta Marching Band Domenico Savio Semarang dapat memahami lagu yang akan dibawakan, lagu yang akan dibawakan diantaranya lagu Serasa, Untukku, dan Cintaku. Menurut Kak Roso melalui lagu yang lebih familiar tersebut peserta 
Marching Band Domenico Savio Semarang akan lebih mudah menangkap materi atau menghafal lagu dengan cepat (wawancara, Maret 2016).

\subsubsection{Program}

Penggerkaan dari program Marching Band Domenico Savio adalah sebagai berikut :

(1) Jadwal Latihan

Jadwal latihan yang dilakukan oleh Marching Band Domenico Savio dilaksanakan sercara rutin pada hari senin dan rabu dimulai pada pukul 13.00 WIB s/d pukul 16.00 WIB. Dalam pembagian waktu yang dilakukan oleh pelatih adalah sebagai berikut:

Tabel 4. Jadwal Latihan Marching Band Domenico Savio Semarang

\begin{tabular}{|c|l|l|l|}
\hline Waktu & \multicolumn{1}{|c|}{ Kegiatan } & \multicolumn{1}{|c|}{ Tempat } & \multicolumn{1}{|c|}{ Pelaksana } \\
\hline $13.00-13.15$ & Apel dan Brifing & Lapangan & Ketua Pelatih \\
\hline $13.15-13.30$ & Penamasan & Lapangan & Pelatih Brass \\
\hline $13.30-14.00$ & Latihan Basic atau dasar & Lapanagan & Pelatih Perkusi \\
\hline $14.00-15.45$ & Latihan Lagu & Lapangan & Semua Pelatih \\
\hline $15.45-16.00$ & Apel dan Evaluasi & Lapangan & Ketua pelatih dan \\
& & & Pembina \\
\hline
\end{tabular}

( Sumber : Suroso, 2016) 
Latihan Marching Band Domenico Savio Semarang diawali dengan apel atau berbaris untuk mendapatkan sebuah informasi dari pelatih, pada saat apel diawali dengan doa dan saat apel peserta baris menurut devisi atau kelompok alat, setelah itu adalah melakukan penamasan secara bersama, latihan dasar, dan latihan materi lagu.

Pada saat latihan dasar peserta akan dipisah menurut devisi atau kelompok alat musik, setelah latihan tersebut selesai akan dilanjutkan pada latihan materi lagu yang juga dilakukan di tempat yang berbeda, dalam latihan lagu kepala pelatih akan memberikan target kepada sie pelatih dengan minimal dalam satu pertemuan adalah sepuluh bar. Latihan akan dilakukan secara bersama-sama apabila latihan lagu perkelompok telah selesai dan target juga selesai.

Pemadatan latihan marching band dalam menghadapi lomba akan dilakukan dua bulan menjelang perlombaan. Hal tersebut ditegaskan oleh Mas Roso selaku kepala pelatih Marching Band Domenico Savio Semarang yang mengungkapkan bahwa menejelang perlombaan akan dilakukan pemadatan dengan menambah jadwal latihan dan menambah intensitas waktu latihan, dalam satu minggu bisa latihan sebanyak empat kali, hal tersebut dilakukan agar materi atau lagu dapat selesai sebelum perlombaan, karena setelah lagu selesai akan dilanjutkan dengan latihan unjuk gelar.

(2) Pendidikan Dasar

Pendidikan dasar merupakan proses pengenalan instrument atau alat yang digunakan dalam marching band, seperti brass, perkusi, dan bendera. 


\section{(3) Materi Latihan Dasar}

Materi latihan merupakan hal yang mendasar bagi peserta supaya dapat memahami marching band secara benar, materi tersebut ditentukan oleh kepala pelatih, yang meliputi latihan dasar, latihan inti dan materi lagu. Dalam materi lagu, Marching Domenico Savio Semarang memesan aransemen kepada pihak luar dengan perjanjian yang telah ditentukan.

Latihan dasar bertujuan untuk memberi pengetahuan terhadap karkter alat-alat musik dan cara bermain alat musik tersebut, latihan dasar tersebut diberikan kepada seluruh devisi dengan pendampingan dari pelatih yang profesional, latihan tersebut meliputi:

\section{Drill / Baris-berbaris}

Dalam materi ini peserta diajarkan bagaimana caranya baris-berbaris sesuai aturan marching band pada umumnya. Peserta beberapa posisi mulai dari posisi siap, jalan ditempat, posisi hormat, istirahat ditempat, hadap kanan, hadap kiri, serong kanan serong, balik kanan, dan sikap memegang alat dalam marching band.

Sebelum melaksanakan drill peserta diwajibkan untuk apel secara bersamasama sesuai deivisi atau baris sesuai dengan alat yang dipegang. Pada umumnya barisan mereka membentuk huruf "U”. Pelaksanaan dari latihan ini bertujuan untuk mengompakan derap langkah dalam sebuah barisan dan memiliki fungsi supaya peserta dapat mengaplikasikan untuk ujuk gelar dalam perlombaan. Didalam perlombaan baris-berbaris merupakan aspek yang penting dalam penilaian membentuk sebuah formasi. 
Pada gambar di bawah menunjukan peserta Marching Domenico Savio sedang melakukan latihan drill. Latihan tersebut dilakukan di luar ruang kelas, latihan tersebut dilakukan secara bersama-sama dengan perintah dari pelatih. Latihan dari drill di bawah bertujuan untuk mengompakkan langkah jalan peserta Marching Band Domenico Savio supaya serempak. Materi dari driil tersebut adalah jalan ditempat, hadap kanan, hadap kiri, serong kanan, serong kiri, dan posisi tubuh saat memegang alat marching band.

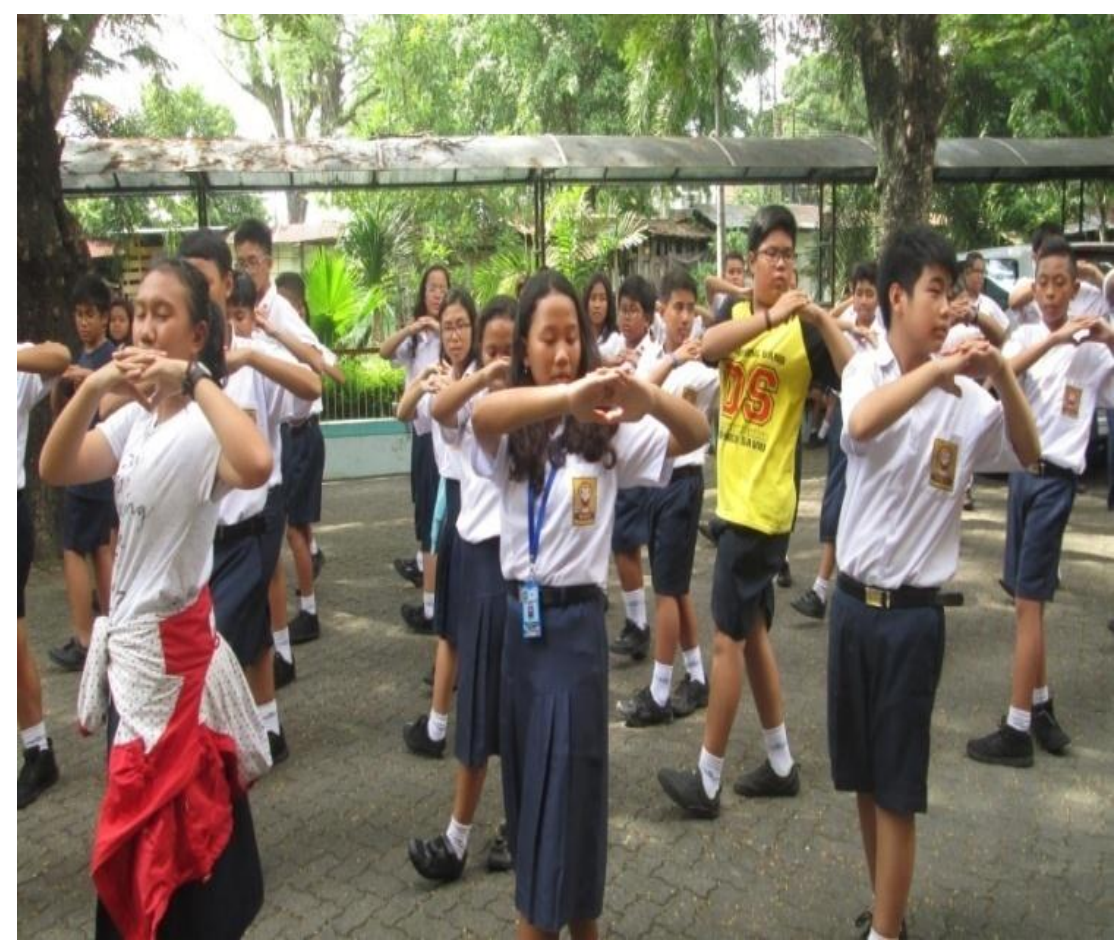

Gambar 3. Latihan Drill atau baris-berbaris

( Sumber : Wibawa, 2016) 


\section{Latihan Sticking}

Setelah apel dan selesai latihan baris-berbaris selesai, akan dilanjutkan dengan latihan peralatan marching band, dalam hal ini tim pelatih sudah membagi sesuai kemampuan untuk melatih peserta. Pada devisi perkusi yaitu snare drum, quartom, bass drum, cymbal, pada tahap tersebut peserta diajarkan sticking, peserta akan diajarkan bagaimana cara memegang stick atau pemukul, setelah itu peserta akan diajarkan tentang materi latihan dasar.

Dalam materi latihan dasar ini peserta diberikan materi tentang single stroke dimulai dengan tempo yang pelan kemudian dilanjutkan dengan tempo yang cepat, tahap selanjutnya peserta akan diberikan materi double stroke setelah materi yang sebelumnya dapat dicapai, dan materi yang ketiga ialah memberikan materi didles setelah kedua materi tersebut dicapai atau dapat dikuasai.

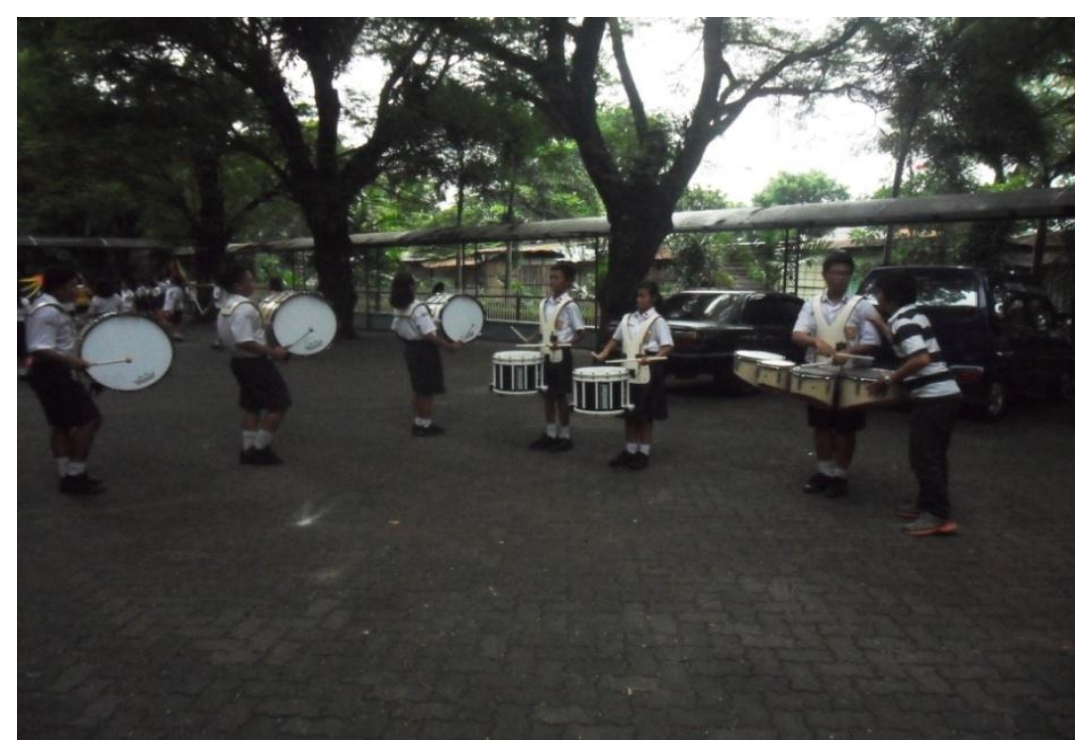

Gambar 4. Latihan Sticking

( Sumber : Wibawa, 2016) 
Mengenai gambar di atas menggambarkan peserta Marching Band Domenico Savio pada devisi perkusi sedang melakukan latihan dasar sticking. Latihan tersebut dipandu dan didampingi pelatih, tujuan dari latihan tersebut adalah untuk menguatkan otot tangan supaya peserta dapat memainkan tempo yang cepat.

\section{Latihan Breathing}

Dalam latihan breathing dilakukan oleh pelatih profesional kepada devisi brass atau divisi tiup seperti trumpet, mellophone, baritone, dan tuba. Teknis dari latihan ini dilakukan setelah latihan drill kemudian dilanjtkan ke latihan tersebut. Pada sesi ini pelatih memberikan perintah kepada peserta untuk meniup mouthpiece atau tempat sumber bunyi tanpa mengeluarkan nada sama sekali. Setelah tahap ini dirasa selesai oleh pelatih, maka akan dilanjutkan pada tahap meniup nada, nada yang ditiup mempunyai jenjang, mulai dari nada bawah kemudian dilanjutkan ke nada yang lebih tinggi.

Pada tahap selanjutnya seletah latihan breathing selesai akan dilanjutkan pada tahap membentuk akor, dengan membagi nada sesuai keinginan pelatih dengan melihat potensi pada peserta. 


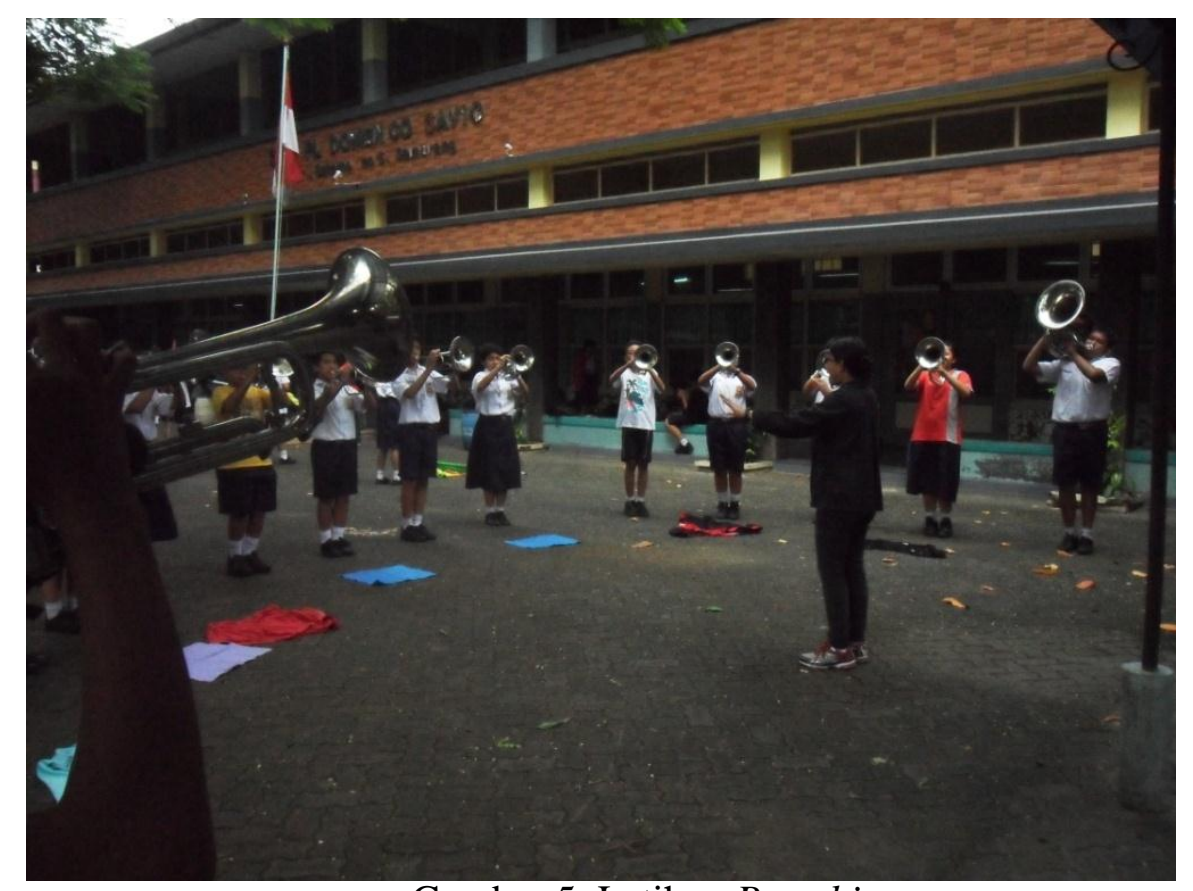

Gambar 5. Latihan Breathing

( Sumber : Wibawa, 2016)

Gambar di atas menujukan peserta Marching Band Domenico Savio sedang berlatih breathing. Latihan tersebut dilakukan oleh devisi brass atau devisi tiup. Latihan tersebut dipandu dan didampingi oleh pelatih, tujuan dari latihan tersebut adalah untuk membentuk ambasir atau posisi bibir pada sumber bunyi supaya benar.

\section{Latihan Dasar Untuk Colour Guard}

Latihan dasar untuk Colour Guard atau penari dalam marching band, dilakukan setelah melakukan apel dan latihan drill secara bersama. Colour Guard atau penari bendera merupakan devisi atau kelompok yang memiliki fungsi sebagai 
penamis dalam pertunjukan marching band dan berfungsi juga sebagai makna dalam sebuah lagu dengan bendera-bendera yang dimainkan.

Teknis dalam latihan tersebut adalah dengan memberikan latihan dasar seperti teknik buterflay, teknik mambo, teknik redo, teknik spin, dan teknik tos. Pemberian materi tersebut secara bertahap, dilakukan dengan memberikan teknik yang paling mudah dan dilanjutkan ke teknik yang lebih sulit.

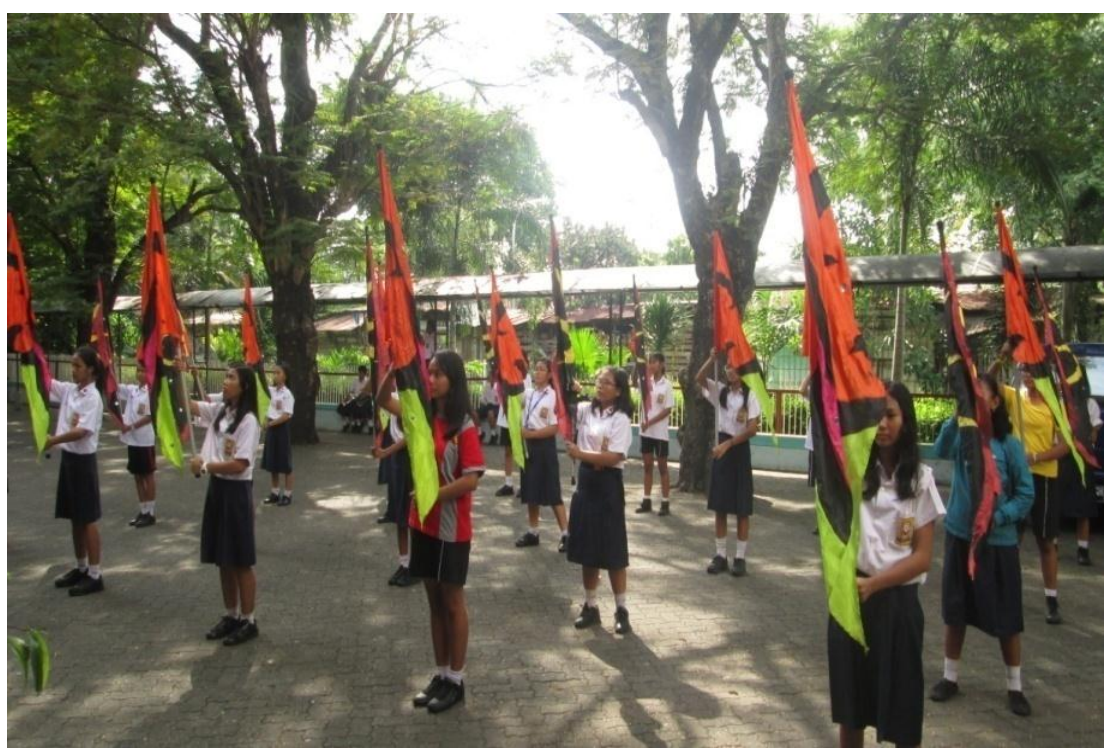

Gambar 6. Latihan Teknik Dasar Colour Gurad

( Sumber : Wibawa, 2016 )

Gamabar 6 tersebut menggambarkan peserta Marching Band Domenico Savio pada devisi colour guard atau pemain bendera sedang latihan dasar. Latihan tersebut dilakukan di luar ruangan dan dipandu dan didampingi oleh pelatih. Latihan tersebut bertujuan agar menguatkan otot tangan dan kelenturan tubuh dari pemain bendera. 


\section{Latihan Dasar pitch}

Devisi pitch atau kelompok perkusi bernada merupakan kelompok yang statis yang memiliki arti bahwa semua pemain pitch dalam marching band pada saat memainkan sebuah lagu dalam unjuk gelar, kelompok tersebut tidak ikut serta dalam bergerak, mereka hanya bermain ditempat. Fungsi dari pitch tersebut adalah sebagai pemerindah lagu dan sebagai akor dalam sebuah lagu.

Latihan dasar yang dilakukan oleh kelompok pitch dimana pelatih merupakan orang yang memberi perintah. Hal yang mendasar bermain pitch adalah cara memegang sebuah mallet atau pemukul, kemudian dilanjutkan dengan belajar tangga nada $\mathrm{B}^{\mathrm{b}}$ atau $\mathrm{B}^{\mathrm{b}}=$ do.

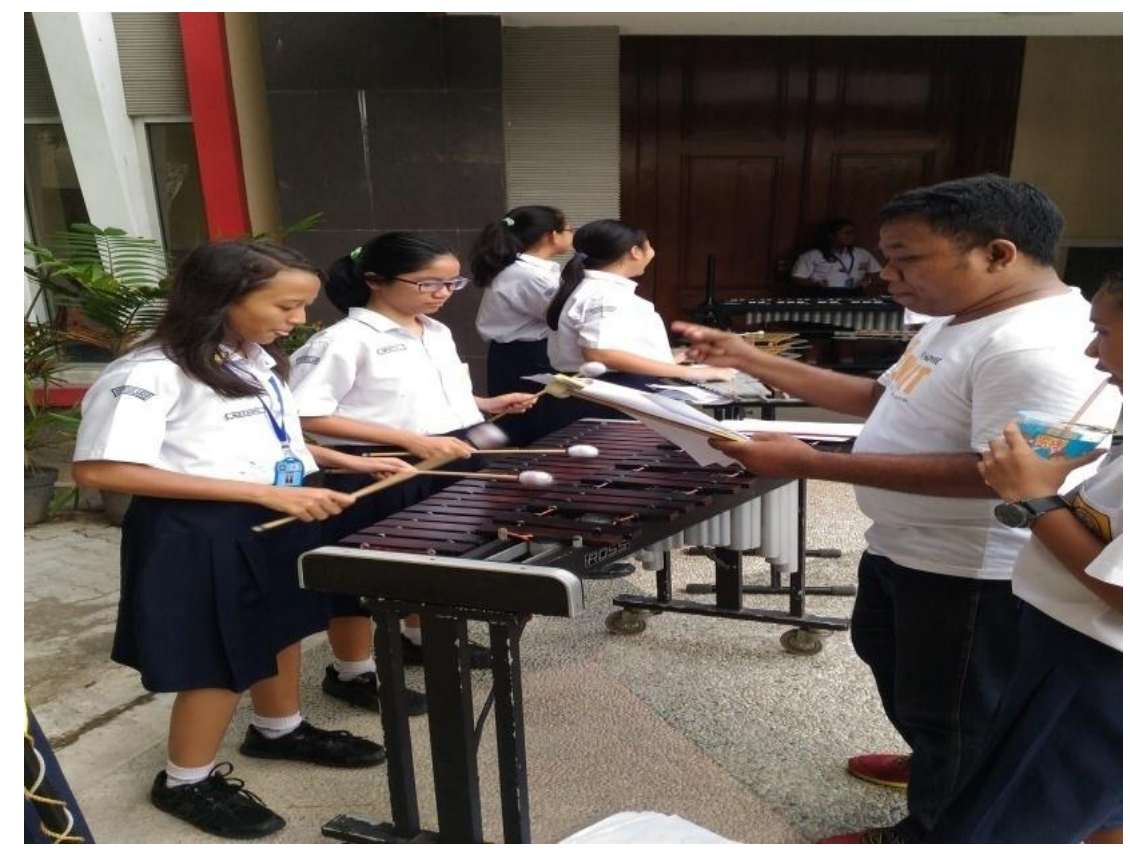

Gambar 7. Latihan dasar pitch

( Sumber : Wibawa, 2016 ) 
Dari gambar 7 tersebut menggambarkan peserta Marching Band Domenico Savio pada devisi pitch sedang berlatih latihan dasar yang dipandu dan didampingi oleh pelatih. Latihan tersebut dilakukan diluar ruangan dan tujuan dari latihan tersebut adalah agar para peserta dapat bermain alat tersebut dengan posisi tangan yang benar dan memainkan nada supaya tepat.

\subsubsection{Faktor Internal dan Eksternal dalam Manajemen Marching Band Domenico Savio Semarang}

Pergerakan adalah pelaksanaan dari perencanaan yang disusun. Pada tahap pergerakan terdapat dua faktor yang dibagi menjadi dua yaitu internal dan eksternal.

\subsection{Faktor Internal}

Penggerakan internal adalah penggerakan dalam manajemen Marching Band Domenico Savio, diantaranya merupakan proses perekrtan personil atau peserta yang mendukung Marching Band Domenico Savio dalam perlombaan.

Tugas dan tanggungjawab pera personil atau peserta Marching Band Domenico Savio diantaranya memberikan kontribusi berupa hasil karya musik. Untuk dapat mendukung karya musik terbaik harus melewati proses latihan secara konsisten.

\subsection{Faktor Eksternal}

Penggerakan ektsernal adalah penggerakan yang dilakukan oleh pelatih, pembuat aransemen dan modal yang didapat sponsor melalui alumni dan perwakilan pihak orang tua murid yang anaknya ikut dalam kegiatan marching band. Dalam hal ini pelatih marching band adalah sebagai penaggung jawab atas keberhasilan dalam mengembangkan kemajuan peserta dalam bermain musik dan berformasi. 
Selain pelatih marching band ada pihak dari luar yaitu pembuat aransemen, yang memiliki tugas untuk membuat aransemen lagu sesuai dengan pesanan, pihak tersebut adalah Mas Hendri yang merupakan pelatih marching band di UNS. Alumni dan orang tua murid dalam hal penggerakan ikut serta dengan mencari sokongan dana melalui penyebaran sponsor-spnosor dan berjualan cendra mata dan menghimpun sumbangan dana dari orang tua.

\subsubsection{Sarana dan Prasarana}

Sarana merupakan atat, alat untuk permainan marching band dari tahun ke tahun dalam perkembangannya semakain komplek, kelengkapan juga harus diperhatikan dan perawatan merupakan hal yang paling penting, sebab perawatan yang baik akan mengefisienkan dana secara bijak. Peralatan Marching Band Domenico Savio Semarang merupakan alat yang vintage khusunya pada devisi brass dan devisi perkusi, alat tersebut merupakan warisan dari tahun 1986, namun cukup banyak yang layak untuk dimainkan. Sampai tahun 2016 ada enam belas jenis alat

yang digunakan Marching Band Domenico Savio. Dengan sebagian besar masih dalam kondisi yang baik.

Sampai tahun 2016, inventaris yang ada di Marching Band Domenico Savio Semarang adalah sebagai berikut: 
Tabel 5. Daftar inventaris peralatan Marching Band Domenico Savio

\begin{tabular}{|c|c|c|c|c|c|}
\hline \multirow{2}{*}{ NO } & \multirow{2}{*}{ Nama Barang } & \multirow{2}{*}{ Jumlah } & \multicolumn{3}{|c|}{ Keadaan } \\
\hline & & & Baik & Cukup & Kurang \\
\hline 1. & Trompet & 25 & 20 & 2 & 3 \\
\hline 2. & Mellophone & 8 & 6 & - & 2 \\
\hline 3. & Baritone & 12 & 12 & - & - \\
\hline 4. & Tuba & 3 & 3 & - & - \\
\hline 5. & Bass Drum & 5 & 4 & - & 1 \\
\hline 6. & Snare Drum & 7 & 4 & - & 3 \\
\hline 7. & Quartom & 2 & 2 & - & - \\
\hline 8. & Cymbal & 5 & 4 & - & 1 \\
\hline 9. & Tongkat Mayor & 3 & 2 & - & 1 \\
\hline 10. & Kostum & 100 & 100 & - & - \\
\hline 11. & Single Flag & 20 & 20 & - & - \\
\hline 12. & Double Flage & 10 & 10 & - & - \\
\hline 13. & Giant Flage & 5 & 4 & 1 & - \\
\hline 14. & Vibraphone & 2 & 2 & - & - \\
\hline 15. & Xylophone & 2 & 2 & - & - \\
\hline 16. & Bells & 8 & 8 & - & - \\
\hline
\end{tabular}

( Sumber : SMP Pangudi Luhur Domenico Savio Semarang, 2016 ) 
Prasarana merupakan kelengkapan yang mendukung dari sarana tersebut. Untuk prasarana Marching Band Domenico savio Semrang memiliki ruangan atau gedung secara khusus sebagai tampat penyimpanan alat-alat marching band.

Prasarana yang lain adalah seperti kelengkapan dalam setiap pertunjukan seperti sepatu, topi, kostum, dan lain-lain. Prasarana tersebut sesuai dengan jumlah personil yang ada yaitu sejumlah 100 orang. Prasarana kelengkapan pertunjukan sudah dirawat dengan baik oleh pihak pengelola Marching Band Domenico Savio Semarang.

\subsubsection{Pengawasan}

(Subekhi Ridhotullah, M.M. dan Mohamad Jauhar, S.Pd. 2015:19) pengawasan adalah proses pengamatan dari keseluruhan kegiatan organisasi guna lebih menjamin bahwa semua pekerjaan yang sedang dilakukan sesuai dengan rencana yang telah ditentukan. Pengawasan adalah kegiatan yang dilakukan oleh manajer atau pihak kepengurusan Marching Band Domenico Savio Semarang dalam mengupayakan agar kegiatan-kegiatan yang dilakukan sesuai dengan perencanaan yang telah ditentukan.

Menurut ibu Maria Yosefa Mariatmi selaku pembina Marching Band Domenico Savio Semrang (wawancara, Maret 2016) mengatakan bahwa dalam pengawasan tersebut dimaksudkan untuk mengetahui hambatan-hambatan, kesalahankesalahan, sehingga dapat segera dicari solusi atau pemecahnya. Dalam hal ini pengawasan yang dilakukan oleh Marching Band Domenico Savio Semarang ada beberapa pihak, diantaranya sebagai berikut: 


\section{Pengurus}

Dalam kepengurusan yang mengawasi adalah ketua dengan cara mengadakan rapat dalam dua minggu sekali, dengan tujuan supaya tugas yang dibagi dapat dalam kepengurusan dapat melaporkan perkembangannya dan hambatan apa saja yang dihadapi serta mencari solusi secara bersama.

2. Anggota

Dalam hal ini Marching Band Domenico Savio Semarang ada dua pihak untuk mengawasi, pertama ada pembina, dimana pembina melakukan pendekatan persuasif pada anggota, kedua adalah ketua pelatih. Dengan pendekatan persuasif diharapkan ada kedekatan anatara pembina dengan anggota dan pelatih dengan anggota, sehingga komunikasi akan berjalan dengan baik

3. Keuangan

Pengawasan keuangan dilakukan oleh pihak kepengurusan, melalui ketua bersama pembina Marching Band Domenico Savio Semrang, dengan cara mengadakan rapat bersama seksi yang lain sebulan sekali untuk mengetahui pengeluaran dan pemasukan keuangan, serta untuk mengetahui informasi tentang masalah keuangan yang terjadi dikepengurusan. 


\section{BAB 5}

\section{PENUTUP}

\subsection{Kesimpulan}

Pola ritme sebagian besar menggunakan tiga pola yaitu $\mathrm{A}, \mathrm{B}$, dan $\mathrm{C}$, pola ritmenya yang dimainkan snare drum terdapat bagian yang memakai not triol pada bagian lagu, snare drum dan quartom pada aransemen tersebut banyak menggunakan teknik ring shoot dan teknik roll, dan pola ritmenya pun menggunakan sinkopasi. Pemegang melodi utama adalah mellophone. Mellophone pada aransemen lagu "Untukku" terdapat nada yang ditiup panjang yaitu selama 24 ketuk, melodi iringan lagu terdapat nuansa musik jawa, dan pada vibraphone nada yang dimainkan adalah nada pembalikan akor yang dimainkan secara arrpegio, melodi keseluruhan dalam arensemen tersebut menggunakan pholyphony. Akor yang digunakan merupakan akor sekunder, pemegang akor adalah tuba dan baritone dengan nada yang ditiup sangat rendah dan bulat, akornya menggunakan akor pembalikan-pembalikan dan memainkan akornyapun ada yang menggunakan teknik stacato.

Manajemen yang diterapkan oleh Marching Band Domenico Savio Semarang dalam pengelolaan sudah baik dengan menggunakan beberapa tahap yaitu perencanaan, pengorganisasian, penggerakan, dan pengawasan yang saling bersinergi menjadi satu. Pihak dari luar pun dilibatkan untuk mengelola Marching Band Domenico Savio Semarang dalam sebuah perlombaan, kepengurusan, dan memberikan masukan-masukan supaya Marching Band dapat bertahan dari persaingan. 


\subsection{Saran}

1. Saran yang dapat diberikan terkait aransemen, bahwa dalam aransemen tersebut memiliki keunggulan di dalam teknik permainan dari segi pola ritme, melodi, dan harmoni yang menjadi ciri khas Marching Band Domenico Savio Semarang hal tersebut haruslah dipertahankan,

2. Namun kekurangannya adalah sumber daya atau peserta harus latihan sangat ekstra untuk memperoleh teknik tersebut ini menyebabkan peserta akan kekurangan waktu untuk belajar pelajaran akademik.

3. Dalam manajemen sudah berjalan baik dengan menerapkan aspek dasar menajemen untuk mengelola Marching Band Domenico Savio Semarang,

4. Namun terdapat kekurangan pada pengelolaan dibagian peremajaan alat dimana masih banyak alat yang belum diperbaiki. 


\section{DAFTAR PUSTAKA}

Arikunto, Suharsimi. 1998.Prosedur Penelitian Suatu Pendekatan Praktik. Jakarta: Renika Cipta.

Bastomi, S. 1996. Dasar-dasar Manajemen. Jakarta : Yayasan Ismlam Teuku Umar.

Basuki, Sugeng, B. A. Dkk. 1980. Seni Musik. Solo : Tiga Serangkai

Bonoe, Pono. 2003. Kamus Musik.Yogyakarta.Kansius Yogyakarta.

Gomes, Faustino C. 2001. Manajemen Sumber Daya Manusia. Yogyakarta: Andi Offst

Hasibuan, Hani. 2001.Dasar-dasar Manajemen Produksi dan Operasi. Yogyakarta: BPFE.

Hartono, 2001. Harmonia Jurnal Pengetahuan dan Pemikiran Seni. Semarang : Jurusan Seni Drama tari, dan musik Fakultas Bahasa dan Seni Universitas Negeri Semarang.

Hidayah, Irine Nurul 2013. Manajemen Marching Band MI-Alhuda Desa Kutoanyar Kec Kedu Kab Temanggung. Skripsi S1. Jurusan Sendratasik. Tidak diterbitkan

Jamalus. 1998.Pengajaran Musik Melalui Pengalama Musik.Jakarta: Departemen Pendidikan dan Kebudayaan. Direktorat Jendral Pendidikan Tinggi.LPTK.

Jazuli, M. 2014. Manajemen Seni Pertunjukan. Yogyakarta : Graha Ilmu.

Koetjaraningrat. 1974. Kebudayaan Mentalitas dan Pembangunan. Jakarta: PT Gramedia.

Koetjaraningrat. 1986. Pengantar Ilmu Antropologi. Jakarta: Rineka Cipta

Lutan, Rusli. 1986. Pengelolaan Interaksi Belajar Mengajar Intrakurikuler dan Ekstrakurikuler. Jakarta Universitas Terbuka.

Margono, 1996. Metode Penelitian Pendidikan. Semarang : Rineka Cipta.

Miler, Hugh M. 2001. Apresiasi Musik. Yogyakarta: Yayasan Lentera Budaya. 
Moloeng, Lexy J. 2000. Metode Peneltian Kualitatif. Jakarta : Remaja Rosda Karya.

Oxford University Press. 2005. Oxfrod Ensiklopedi Pelajar. Jakarta: Widyadara.

Pasaribu, Amir.1986.Analisis Musik Indonesia.Jakarta:PT.Pantja Simpati.

Sumaryanto, Totok F. 2014. Metodologi Penelitian Kualitatif Untuk Pendidikan Seni. Semarang : Fakultas Bahasa dan Seni.

Picker. 1997. Music of Sound. Jakarta: PT. Gramedia.

Prasetia, Herdiyan Adi. 2010.Manajemen Produksi Kelompok Musik Shaggydog di Yogyakarta:Kajian Manjemen Produksinya.Skripsi S1. Jurusan Sendratsik. Tidak diterbitkan.

Ridhotullah,Subekhi, M.M. \& Mohamad Jauhar, S.Pd. 2015. Pengantar Manjamen. Jakarta : Pretasi Pusaka.

Salim, Agus. 2010. Adaptasi Pola Ritme Dangdut pada Ansambel Perkusi. Skripsi S1. Jurusan Musik. Fakultas Seni Pertunjukan. Institut Seni Indonesia Yogyakarta. Tidak diterbitkan.

Soeharto, 1992. Kamus Musik. Jakarta : PT. Gramedia.

Purnaningtyas, A., \& Suharto, S. (2011). PENGARUH KECERDASAN EMOSI TERHADAP PRESTASI BELAJAR SISWA MATA PELAJARAN SENI BUDAYA SMP. Harmonia: Journal Of Arts Research And Education, 10(1). doi:http://dx.doi.org/10.15294/harmonia.v10i1.56

Suharto, S. (2011). PENGEMBANGAN MATERI DAN KEGIATAN PEMBELAJARANNYA DALAM KURIKULUM TINGKAT SATUAN PENDIDIKAN BIDANG SENI MUSIK. Harmonia: Journal Of Arts Research $\quad$ And (3). doi:http://dx.doi.org/10.15294/harmonia.v8i3.780

Sule, Erine Tisnawati \& Kurnoawan Saefullah. 2005. Pengantar Manajemen. Jakarta : Kecana. 
Susetyo, Bagus.2007. Pengkajian Seni Pertunjukan Indonesia. Fakultas Bahasa dan Seni Universitas Negeri Semarang

Syukur.2005. Peta Kompetensi Guru Seni. Bandung : Universitas Pendidikan Indonesia

Tim Penyusun World Book Ensyclopedy. 1996. Ensyclopedy Music. Jakarta : Widyadara.

Utomo, Udi. 1993. Media. Semarang : Fakultas Pendidikan Bahasa dan Seni Semarang.

Widia Pekerti. 2005. Pendidikan Seni Musik Tari Drama.Jakarta. Universitas Terbuka.

Yoyok. 2007. Pendidikan Seni Budaya. Jakarta : Yudhistira.

(http://edwinssuryaputra.wordpress.com /2013/11/28/teori-solfegio).

(http://www.annneahira.com/seni-musik.htm)

(http://edukasi.kompasiana.com/2010/09/unsur-unsur-musik-irama-dan-melodi-

307423.html)

(https://mgmpseni.wordpress.com/materi-belajar/seni-musik/semester-1/kelasviii/aransemen-musik/) 


\section{HASIL WAWANCARA}

Dalam penelitian ini, peneliti melakukan wawancara pada :

\section{Pembina Marching Band Domenico Savio :}

1. Siapa nama Anda?

Jawaban : Maria Yosefta Mariatmi, S.Pd.

2. Berapa usia Anda?

Jawaban : Usia saya lima puluh tiga tahun.

3. Bagaimana latar belakang pendidikan Anda?

Jawaban : Pendidikan terakhir saya S1.

4. Bagaimana latar belakang berdirinya Marching Band Domenico savio?

Jawaban : Berdirinya Marching Band Domenico Savio Semarang tersebut tidak lepas dari terbentuknya drum and, awal mula terbentuknya marching band didahului dengan drum band dahulu, tepatnya pada tahun 1984. Setelah selang dua tahun drum band diganti dengan marching band oleh usulan orang tua murid. Pada 
tahun 1986 marching band terbentuk dengan penambahan alat-alat yaitu alat tiup dan alat pitch.

5. Kapan dan sudah berapa lamakah Marching Band Domenico Savio Semarang berdiri?

Jawaban : Berdiri dan terbentuknya marching band pada tahun 1986, prestasinya juga lumayan bagus ditahun 1996 Marching Band Domenico Savio pernah ikut lomba GPMB ( Grand Prix Marching Band ) sebagai finalis. Namun memasuki tahun 1999 marching band mulai diminati oleh siswa dan pengelolaanya menurun. Tetapi ditahun 1998 Marching Band Domenico Savio sempat menggelar pertunjukan dilapangan sekolah dengan tema "Cinta"

6. Pada hari apakah Marching Band Domsav latihan?

Jawaban : Macrhing Band Domenico Savio diera sekarang ini latihan pada hari senin dan rabu, dimulai pukul 13.00 sampai dengan pukul 16.00

7. Bagaimana struktur organisasi Marching Band Domenico Savio? Jawaban : Struktur dari organisasi Marching Band Domenico Savio Semarang, yang pertama itu ada pelindung yaitu kepala sekolah atau bruder, selajuntya ada koordinator ektrakurikuler, pembina marching band, kemudian ketua marching band, wakil ketua, sekertaris, bendahara, humas, dan sie pembantu umum. Ketua dan jajarannya tersebut dibentuk dengan menggandeng wali murid dari siswa yang anaknya ikut ekstrakurikuler marching band dan para alumni yang simpatik dengan marching band.

\section{Pelatih Marching Band Domenico Savio :}

1. Siapa nama Anda?

Jawaban : Suroso biasa dipanggil Kak So.

2. Berapa usia Anda?

Jawaban : Usia saya tiga puluh tiga tahun.

3. Bagaimana latar belakang pendidikan Anda? 
Jawaban : pendidikan saya yang terakhir adalah SMA tapi duhulu saya sempat kuliah ekonomi tetapi hanya sampai pada semester lima.

4. Apakah Anda pernah mengikuti pendidikan musik?

Jawaban : Saya tidak pernah mengenyam pendidikan musik, tetapi saya mengenal musik pada waktu kuliah dengan mengikuti marching band, pada waktu itu saya bergabung dengan marching band Semarang yaitu Arimbi.

5. Dalam mengaransemen lagu untuk Marching Band Domenico Savio, Anda membuat sendiri atau pesan kepada orang lain?

Jawaban : Saya tidak membuat sendiri mas, saya pesan kepada orang lain, kepada Mas Hendri pelatih marching band UNS Solo.

6. Jika memesan kepada orang lain, ada kriteria terntentu yang disampaikan?

Jawaban : kriteria tertentu tidak terlalu banyak dalam arti, saya hanya memberikan lagu yang saya ingin aransemen, kemudian pesan saya hanya simpel jangan terlalu susah pada lagu tersebut, dikarenakan peserta Marching Band Domenico Savio semuanya baru atau dapat dikatakan dimulai dari nol.

7. Bagaimana tema lagu yang ada buat untuk mengikuti lomba di Hamengkubuwono Cup?

Jawaban : Tema yang saya buat adalah "Tribut Of Chrisye" atau mengenang (Alm) Chisye. Tujuan dari tema tersebut adalah supaya peserta Marching Band Domeico Savio dapat belajar materi lagu dengan cepat, dikarenakan lagu yang saya pilih merupakan lagu yang sangat familiar didengar.

\section{Pelatih Marching Band Domenico Savio :}

1. Siapa nama Anda?

Jawaban : Setiana Eka Rini

2. Berapa usia Anda?

Jawaban : Dua puluh tiga tahun. 
3. Bagaimana latar belakang pendidikan Anda?

Jawaban : Pendidikan terakhir saya adalah S1, lulusan dari UNNES tahun 2015, jurusan PKN.

4. Apa motivasi Anda menjadi pelatih Marching Band?

Jawaban : Motivasi saya menjadi pelatih marching band adalah untuk menyalurkan ilmu marching saya, supaya dapat berkembang.

5. Sudah berapa Anda menjadi pelatih Marching Band?

Jawaban : Saya menjadi pelatih kira-kira sudah dua tahunan mas.

6. Berapa kali Anda melatih dalam Marching Band Domenico Savio?

Jawaban : Saya melatih Marching Band Domenico Savio, dua kali dalam seminggu, namun jika ada pemadatan mungkin empat kali dalam seminggu.

7. Bagaimana mengkoordinasikan para pemain yang telah diseleksi?

Jawaban : Saya mengkoorganisasikan sesuai dengan perintah dari ketua pelatih, yaitu dengan memberikan materi yang sudah ada.

8. Bagaimana menggerakan para pemain?

Jawaban : Pada saat menggerekan pemain yang dimulai dari nol, saya memberikan materi dasar dan dilanjutkan dengan materi lagu.

9. Bagaimana Anda merencanakan aransemen?

Jawaban : Kalau masalah aransemen saya tidak tahu, saya hanya dapat materi tersebut dari ketua pelatih.

10. Bagaimana Anda melatih aransemen dalam Marching Band?

Jawaban : Saya saat melatih sebuah materi aransemen, yang saya pertama lakukan adalah mempelajari dahulu materi tersebut, pada saya mengajar materi saya akan menyesuaikan dengan perintah ketua pelatih, yaitu 10 bar atau 20 bar dalam satu pertemuan.

11. Apa strategi yang Anda gunakan untuk mengajarkan aransemen?

Jawaban : strategi saya yaitu, dengan membuat peserta merasa nyaman, dengan diselingi candaan namun tetap serius.

12. Bagaimana Anda mengawasi latihan Marching Band? 
Jawaban : Dalam proses pengawasan materi latihan, saya melihat dan memperhatikan peserta dengan teliti, jika ada kesalahan saya akan berikan masukan agar peserta dapat memperbaiki.

\section{Alumni Marching Band Domenico Savio Semarang :}

1. Siapa nama Anda?

Jawaban : Crhistina Katty

2. Berapa umur Anda?

Jawaban : Tiga puluh tiga tahun.

3. Bagaimana latar pendidikan Anda?

Jawaban : Latar belakang, yaitu pendidikan terakhir saya adalah S1 lulusan ekonomi dari UKSW.

4. Apa motivasi Anda dalam membangkitkan Marching Band Domenico Savio?

Jawaban : Bertepatan tempat tinggal saya di Semarang dan anak sayapun sekolah di SMP Pangudi Luhur Domenico Savio Semarang, jadi saya sering berkunjung ke sekolah tersebut untuk menjemput anak. Motivasi saya dalam membangkitkan Marching Band Domenico Savio adalah, supaya marhing band tersebut dapat kembali berjaya seperti dahulu pada saat saya mengikuti kegiatan tersebut.

5. Sudah berapa lama Anda mengikuti kegiatan Marching Band Domsav? Jawaban : Saya mengikuti kegitan ini kira-kira sudah dua tahun mas.

6. Bagaimana bentuk kontribusi yang Anda lakukan untuk Marching Band Domsav?

Jawaban : Kontribusi yang saya berikan adalah dengan memberikan ide-ide seperti bagaimana kostum yang akan dipakai, bagaimana akomodasi yang akan dipakai dalam sebuah perlombaan. Dalam pendanaanpun saya ikut membuat proposal kegiatan dan membagikan proposal tersebut. 


\section{DATA RESPONDEN}

1. Pembina Marching Band Domenico Savio

Nama : Maria Yosefta Maritmi, S.Pd.

Tempat Tanngal Lahir : Semarang, 29 Maret 1963

Alamat : Jl. Dr. Soetomo No 35. Kel Barusari

Kec Semarang Selatan

Kota Semarang

2. Ketua Pelatih Marching Band Domenico Savio

Nama : Suroso

Tempat Tanngal Lahir : Kendal,11 September 1983

Alamat

: Jl. Segaran Baru III No. 3

RT 05/011. Kel. Purwoyoso Kec. Ngaliyan

Kota Semarang

3. Pelatih Brass Marching Band Domenico Savio

Nama

: Setiana Eka Rini, S.Pd.

Tempat Tanngal Lahir : Kudus,17 September 1993

Alamat : Desa Jepang 
RT 03/010. Kel. Mejobo

Kab. Kudus

4. Alumni Marching Band Domenico Savio

Nama

: Crhistina Katty

Tempat Tanngal Lahir : Semarang, 10 Maret 1983

Alamat

: J1. Tumpang Raya No.10

RT 08/11. Kel. Lempong Sari.

Kec. Semarang Selatan

Kota Semarang

FOTO

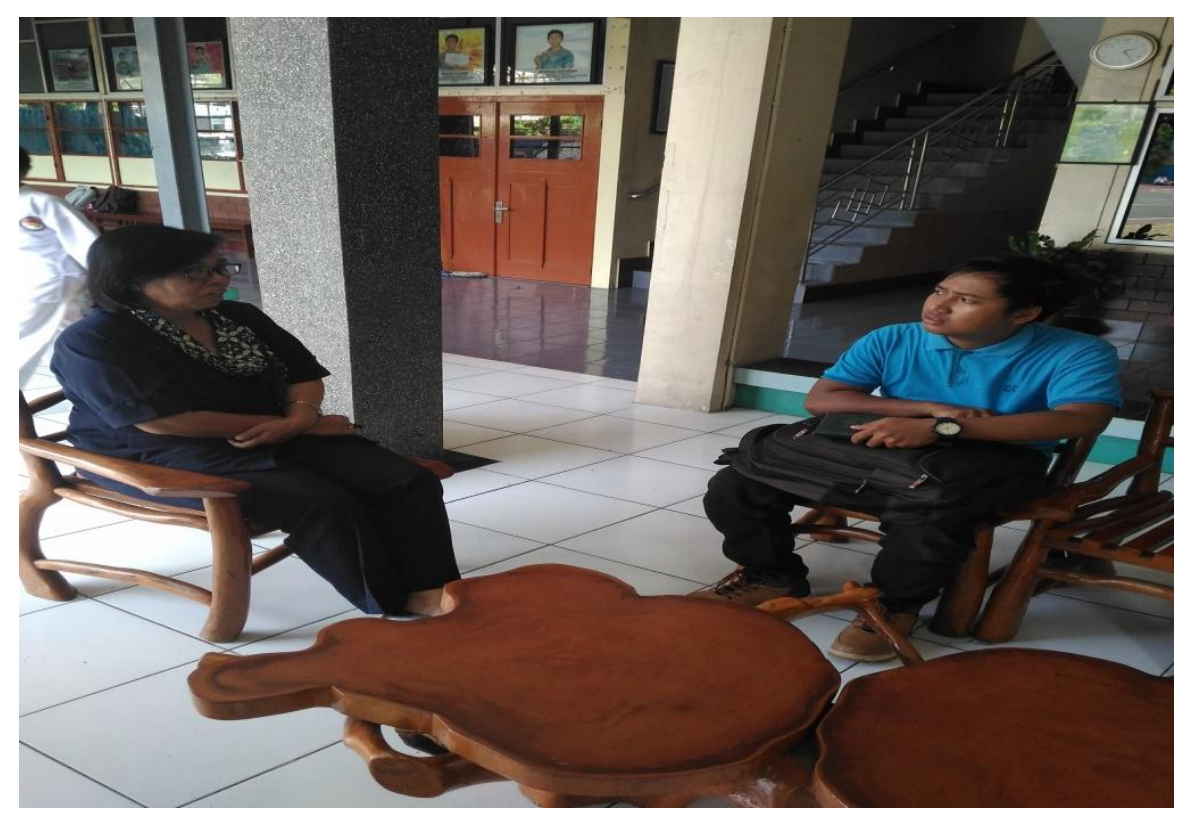

Foto 1. Wawancara dengan pembina Marching Band Domenico Savio Semarang ( Foto Iyar Ekklesia Putra Wibawa, Maret 2016)

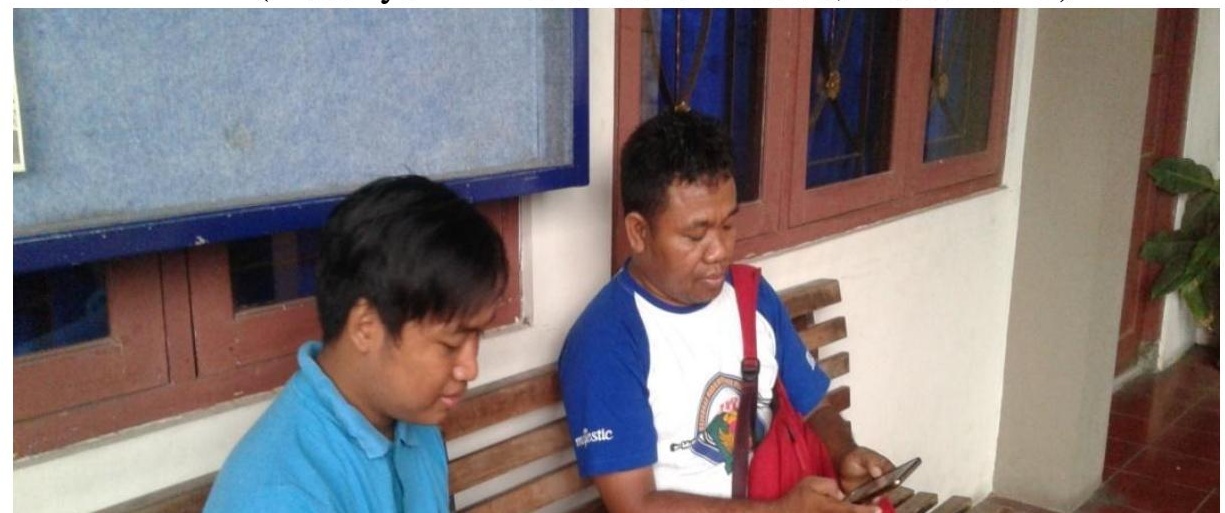


Foto 2. Wawancara dengan pelatih Marching Band Domenico Savio Semarang ( Foto Iyar Ekklesia Putra Wibawa, Maret 2016 )

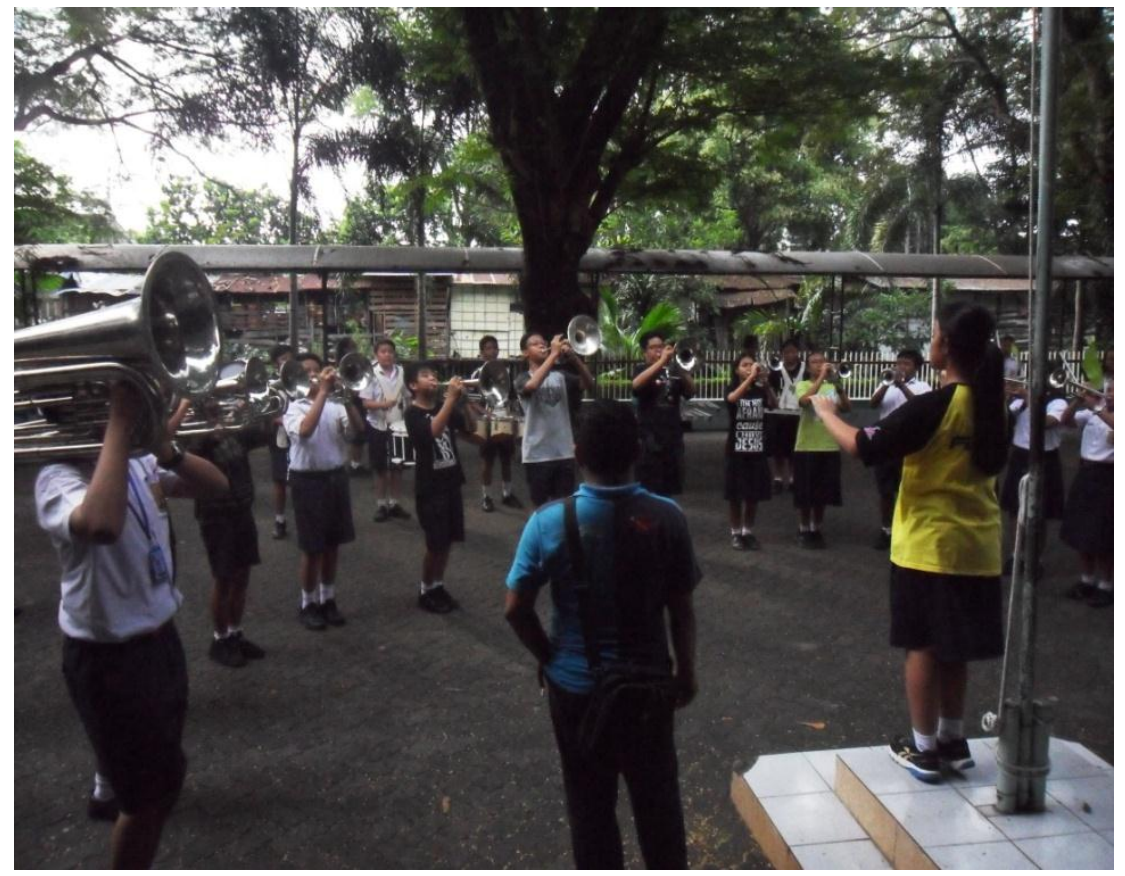

Foto 3. Latihan gabungan antar devisi ( Foto Iyar Ekklesia Putra Wibawa, Maret 2016 )

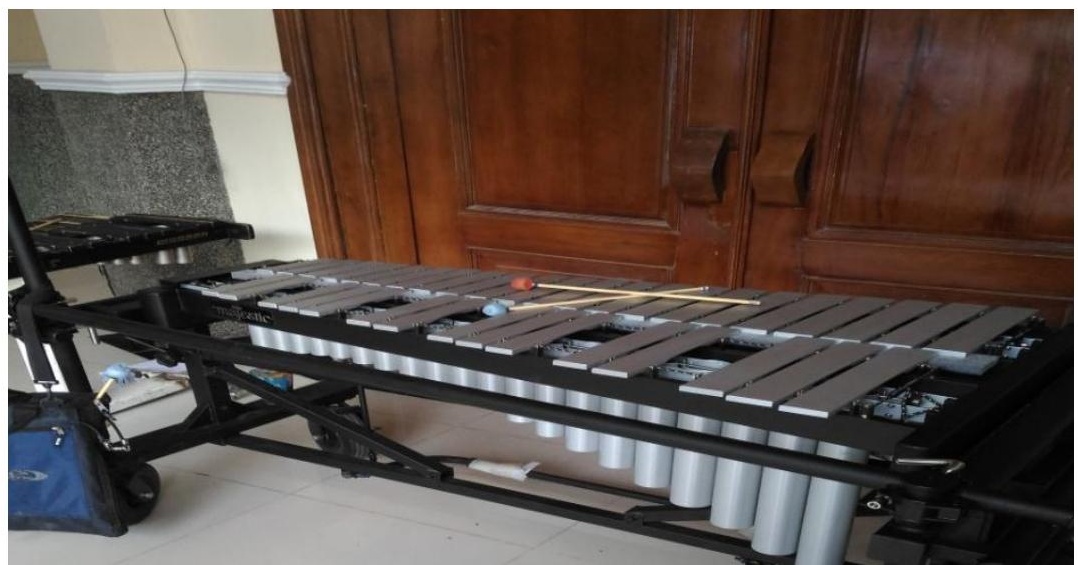


Foto 4. Vibraphone salah satu isntrument pada pitch yang digunakan Marching Domenico Savio Semarang ( Foto Iyar Ekklesia Putra Wibawa, Maret 2016 )

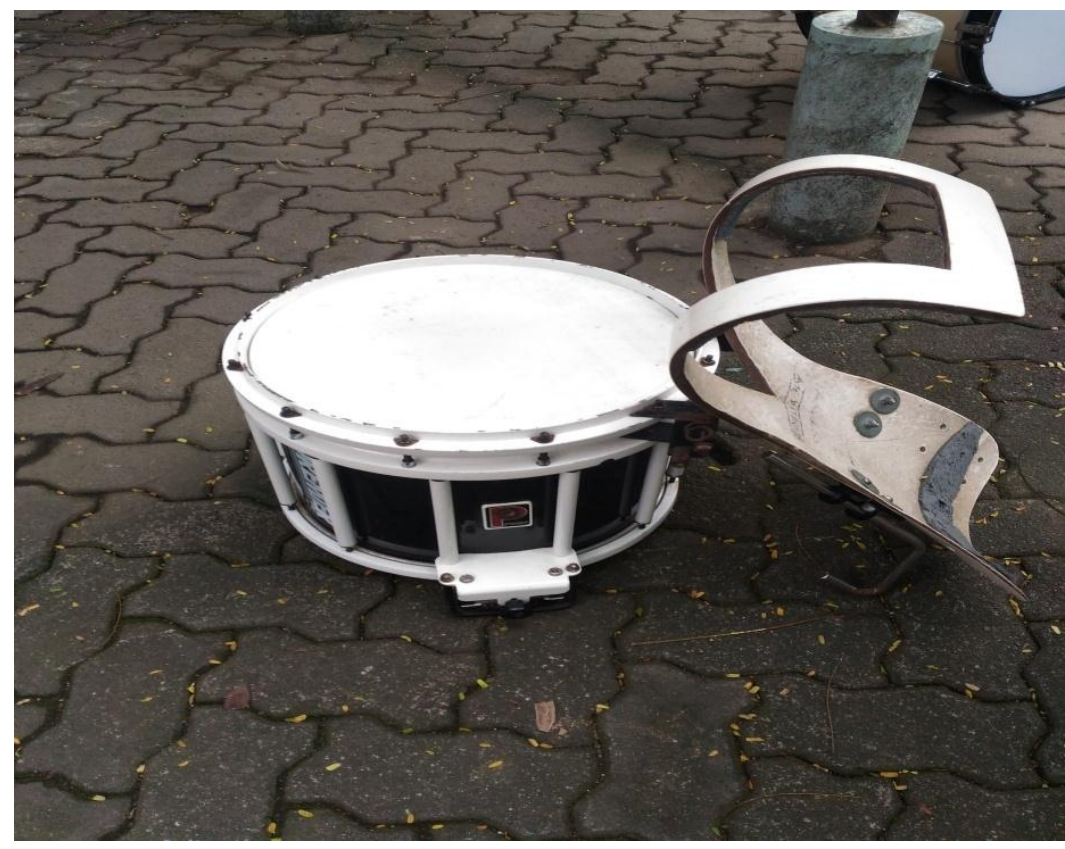

Foto 5. Snare Drum salah satu isntrument pada perkusi yang digunakan Marching Band Domenico Savio Semarang

( Foto Iyar Ekklesia Putra Wibawa, Maret 2016 )

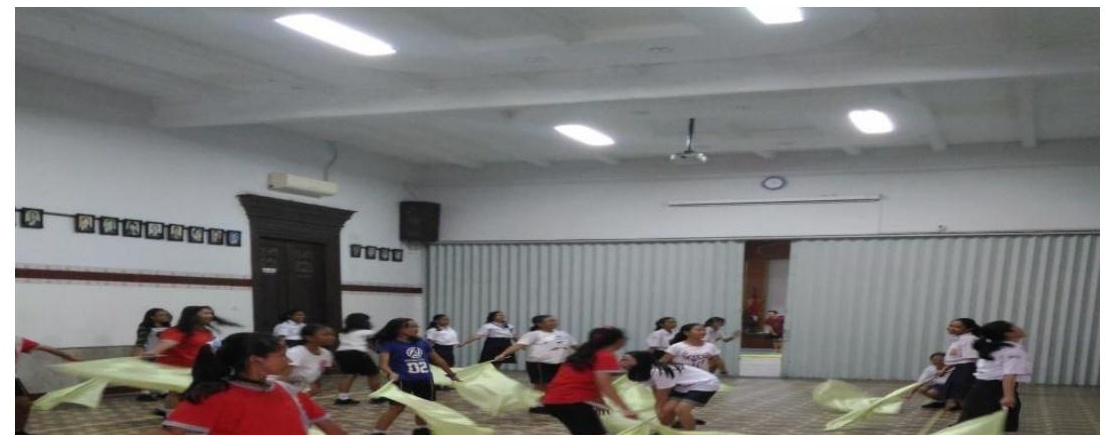


Foto 6. Bendera yang digunakan Marching Band Domenico Savio Semarang

( Foto Iyar Ekklesia Putra Wibawa, Maret 2016 )

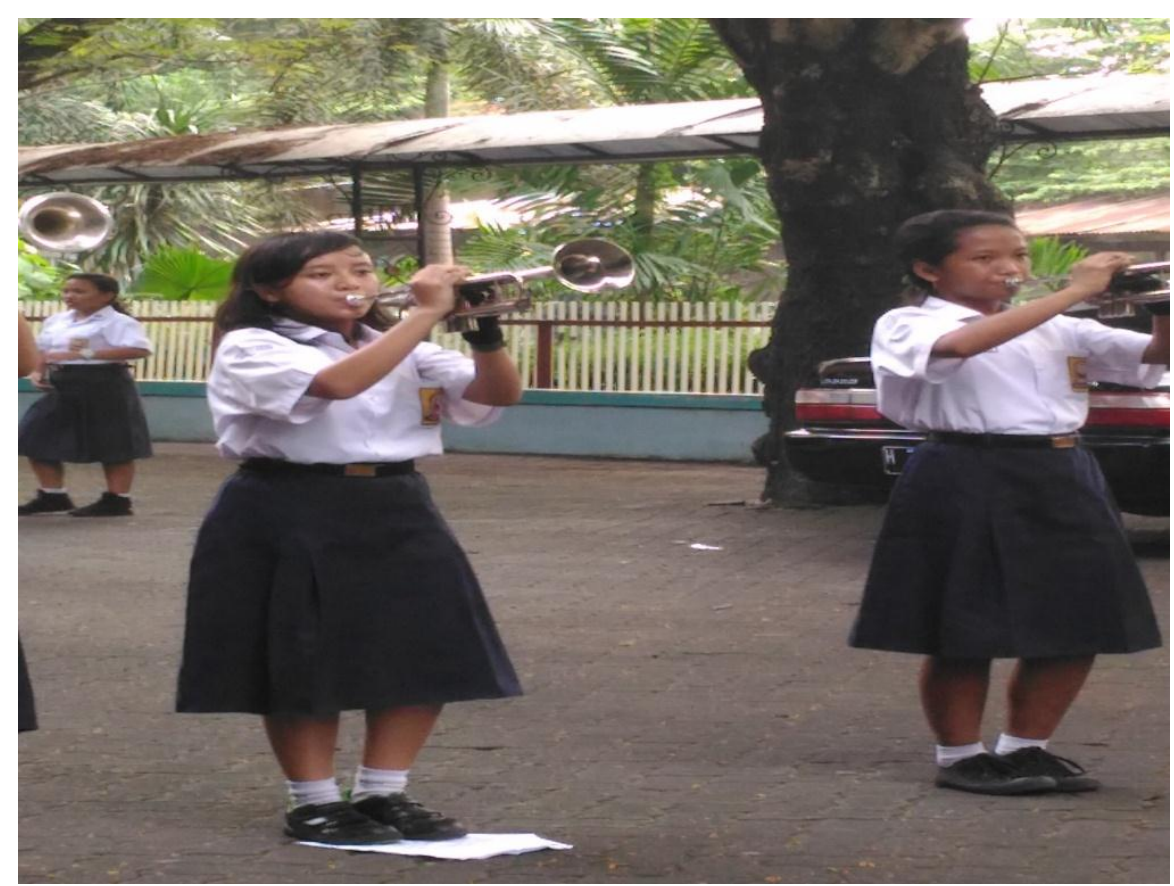

Foto 7. Trumpet salah satu isntrument pada brass yang digunakan Marching Band Domenico Savio Semarang ( Foto Iyar Ekklesia Putra Wibawa, Maret 2016 )

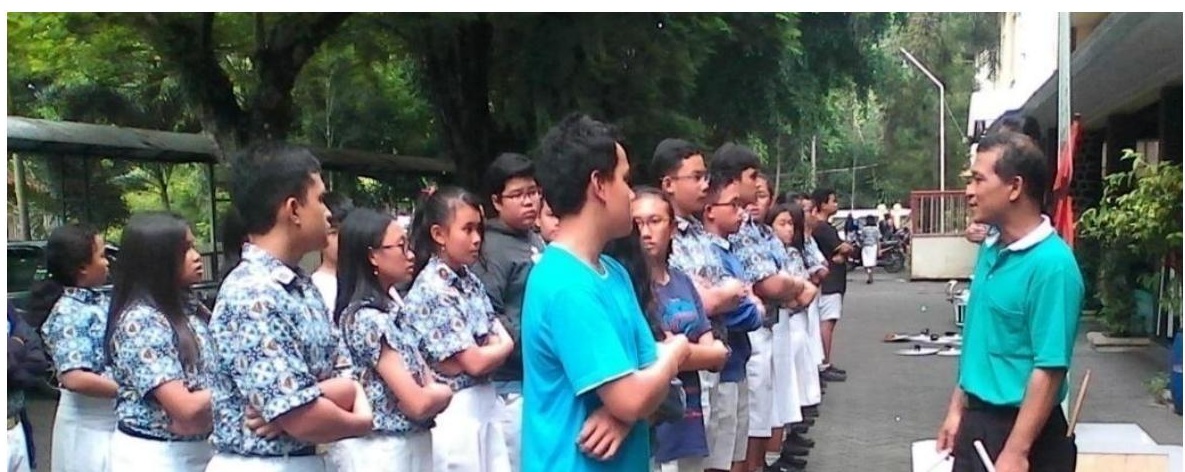


Foto 8. Apel yang dipimpin oleh salah satu pelatih Marching Band Domenico Savio Semarang ( Foto Iyar Ekklesia Putra Wibawa, Maret 2016 )

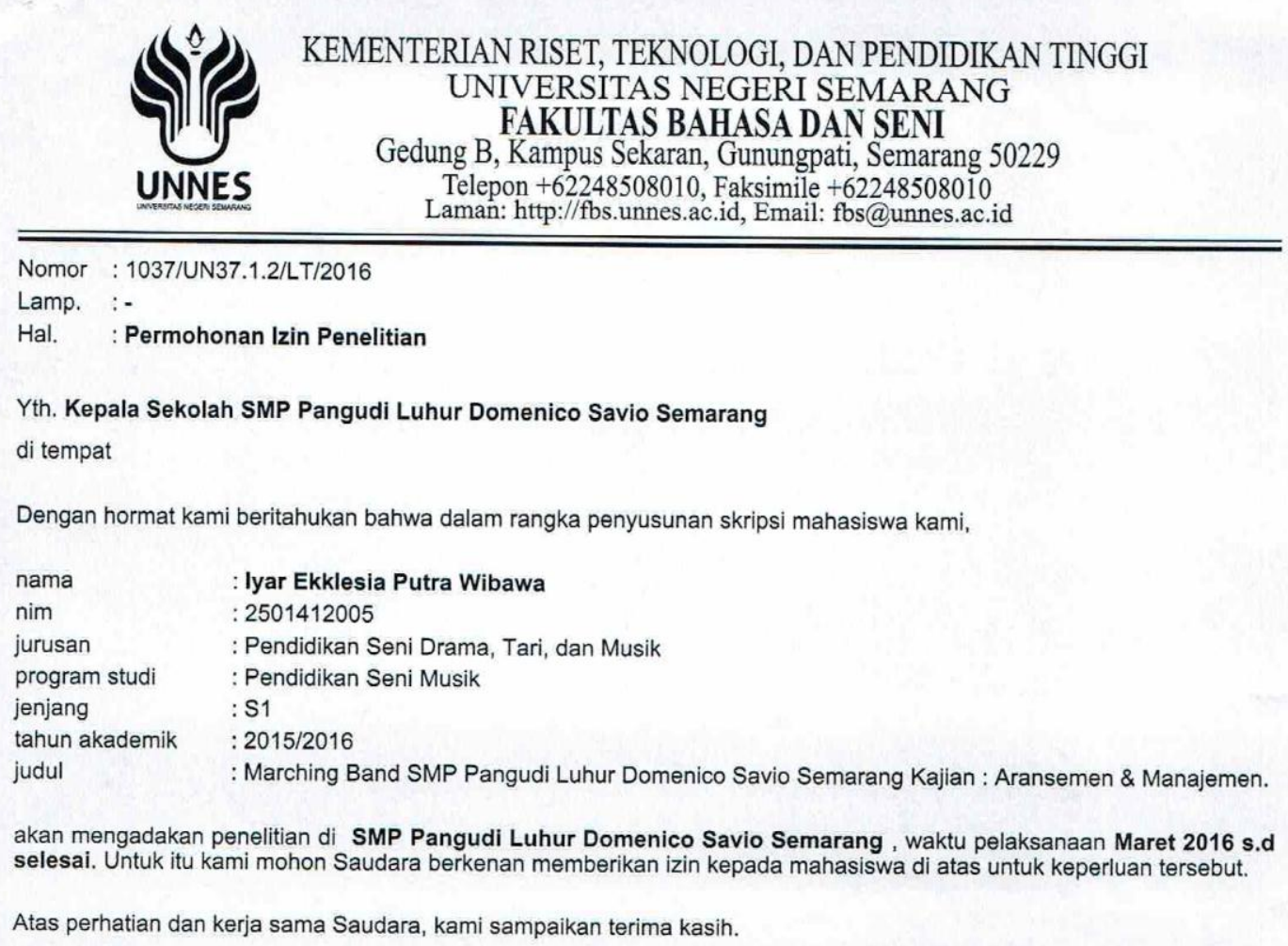

Nomor : 1037/UN37.1.2/LT/2016

Lamp. :-

Hal. : Permohonan Izin Penelitian

Yth. Kepala Sekolah SMP Pangudi Luhur Domenico Savio Semarang

di tempat

Dengan hormat kami beritahukan bahwa dalam rangka penyusunan skripsi mahasiswa kami,

nama : Iyar Ekklesia Putra Wibawa

nim : 2501412005

jurusan : : Pendidikan Seni Drama, Tari, dan Musik

program studi : Pendidikan Seni Musik

jenjang : : 1

tahun akademik $\quad: 2015 / 2016$

judul : : Marching Band SMP Pangudi Luhur Domenico Savio Semarang Kajian : Aransemen \& Manajemen.

akan mengadakan penelitian di SMP Pangudi Luhur Domenico Savio Semarang, waktu pelaksanaan Maret 2016 s.d selesai. Untuk itu kami mohon Saudara berkenan memberikan izin kepada mahasiswa di atas untuk keperluan tersebut.

Atas perhatian dan kerja sama Saudara, kami sampaikan terima kasih.

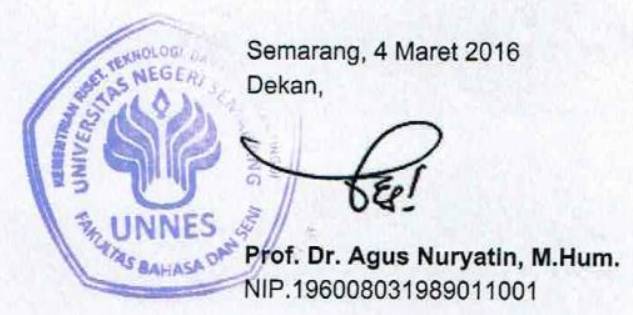




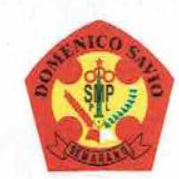

\section{YAYASAN PANGUDI LUHUR SMP PL DOMENICO SAVIO}

Jalan dr. Sutomo 6 Telepon ( 024 ) 8315609 Fax (024) 8412441 SEMARANG

Website : www.domsav.pangudiuhur.org e-mail : domsav@pangudiluhur.ors

No. : 142/SMP.DS/D.2/IV/2016 30 April 2016

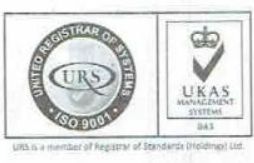

Hal : Keterangan

Lamp : -

Yth. Dekan Fakultas Bahasa dan Seni

Universitas Negeri Semarang

Kampus Sekaran Gunungpati

Semarang

Dengan hormat,

Yang bertandatangan di bawah ini, Kepala SMP PL Domenico Savio meneran jkan bahwa :

$\begin{array}{ll}\text { nama } & : \text { Iyar Ekklesia Putra Wibawa } \\ \text { nim } & : 2501412005 \\ \text { jurusan } & : \text { Pendidikan Seni Drama, Tari, dan Musik } \\ \text { program studi } & : \text { Pendidikan Seni Musik } \\ \text { jenjang } & : \text { S } 1 \\ \text { tahun akademik } & : 2015 / 2016\end{array}$

Telah melaksanakan tugas sebagai berikut :

Judul : Penelitian pada Marching Band SMP Pangudi Luhur Domenico Savio Semarang Kajian : Aransemen \& Manajemen

Lokasi : SMP PL Domenico Savio

Waktu pelaksanaan : 4 Maret-10 April 2016

Demikian surat keterangan dibuat untuk dapat digunakan sebagaimana mestinya. 


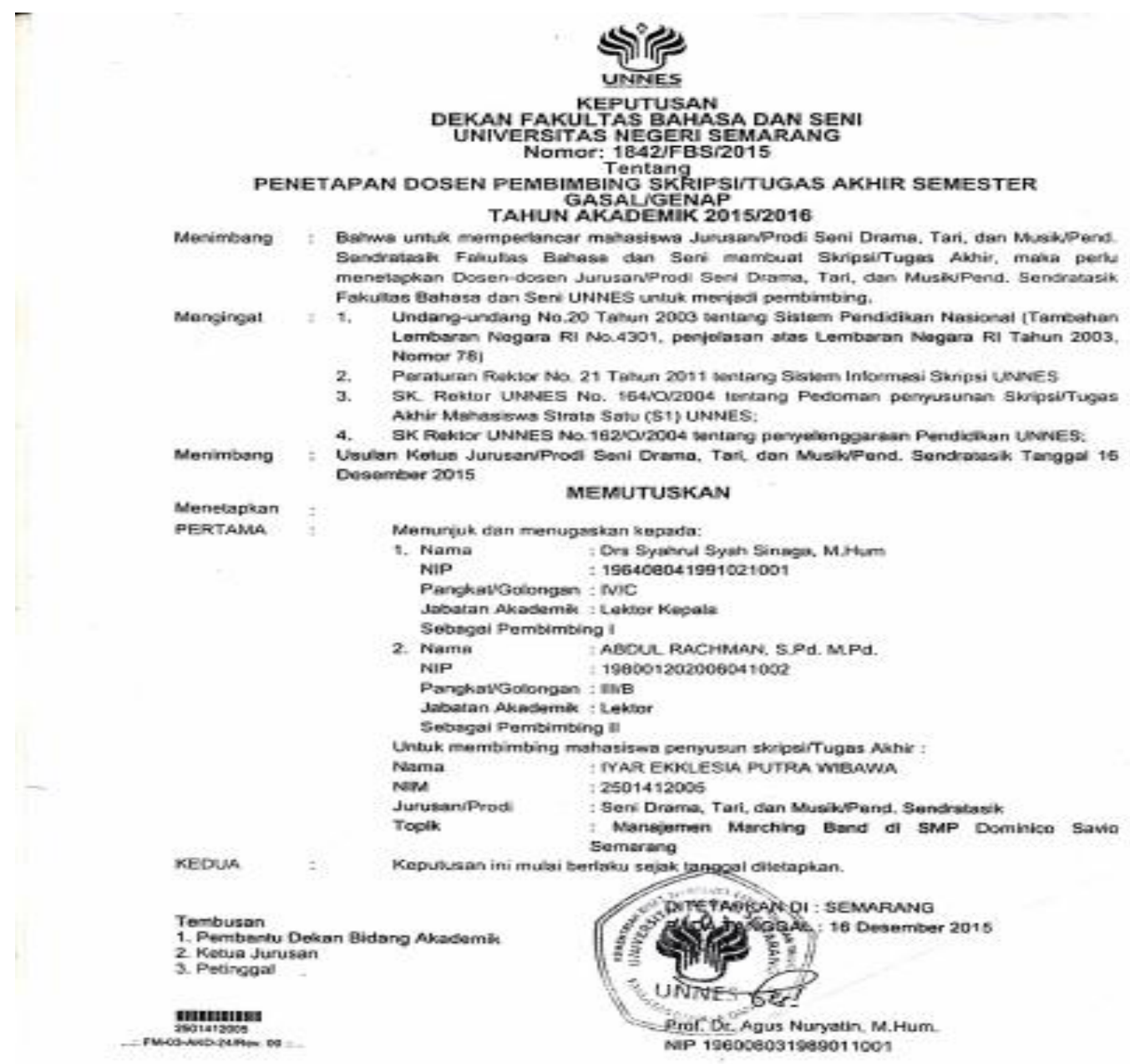




\section{PARTITUR}




\section{Untukku- Chrisye}

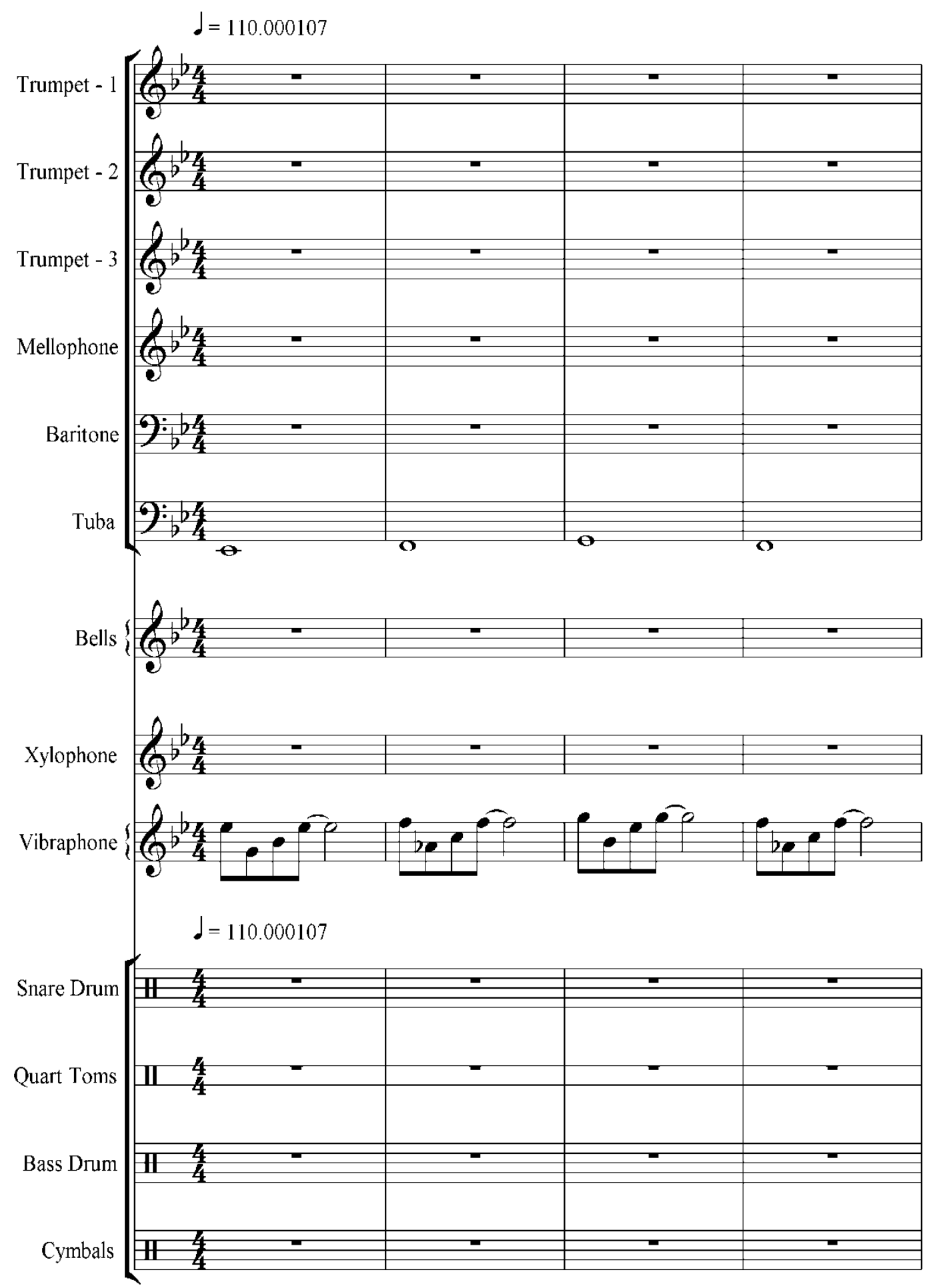

SMART management (C) 2015 

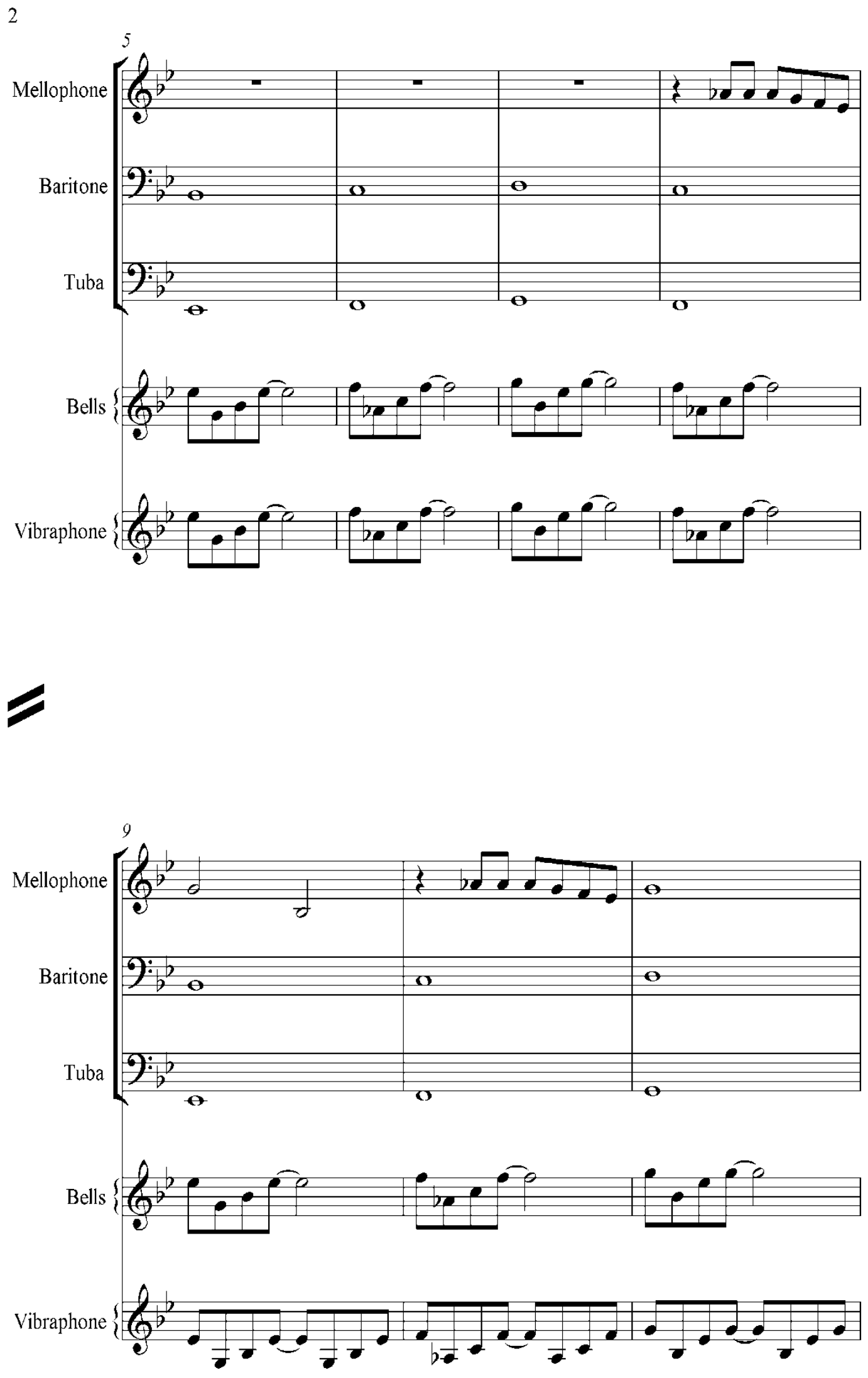


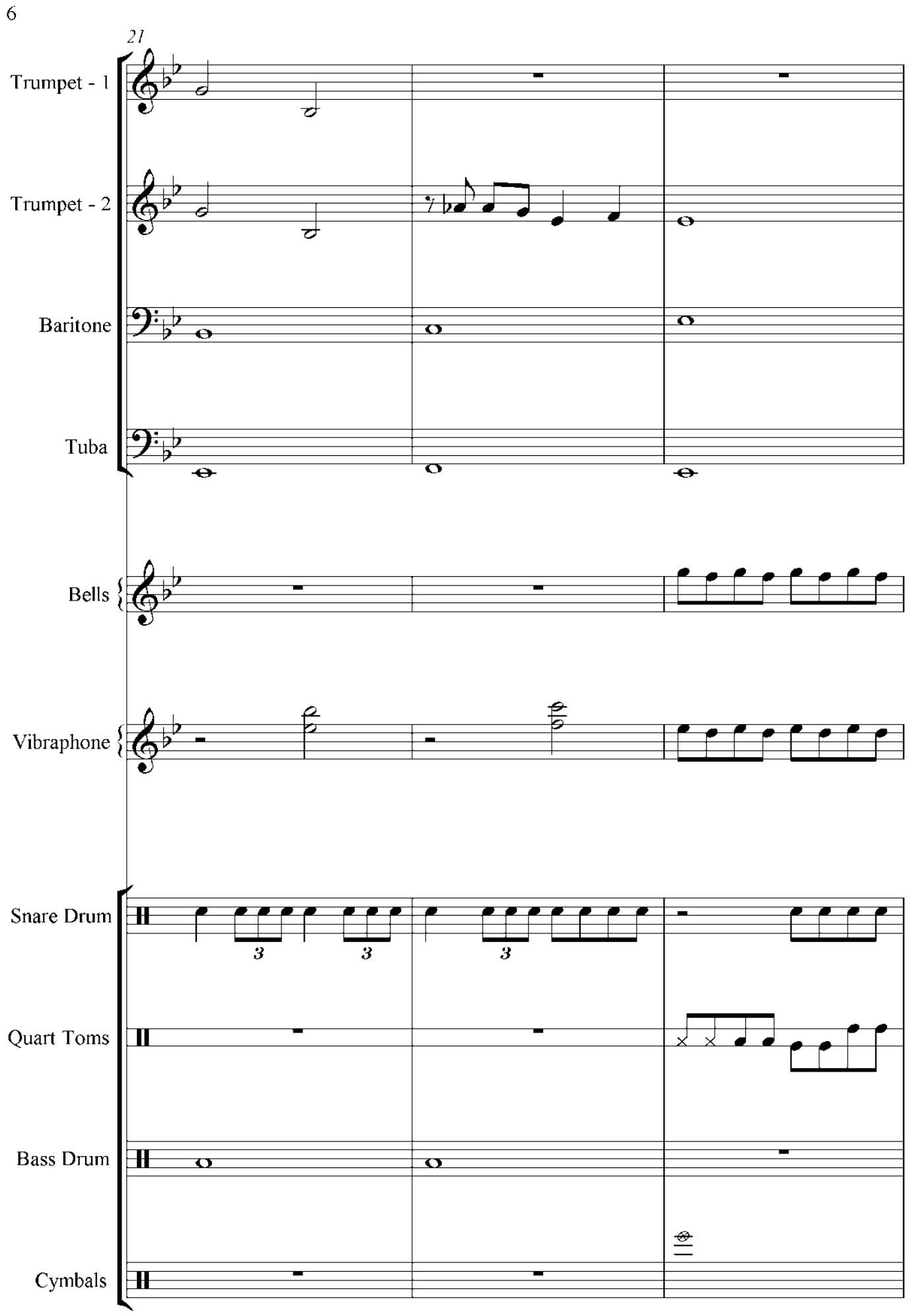




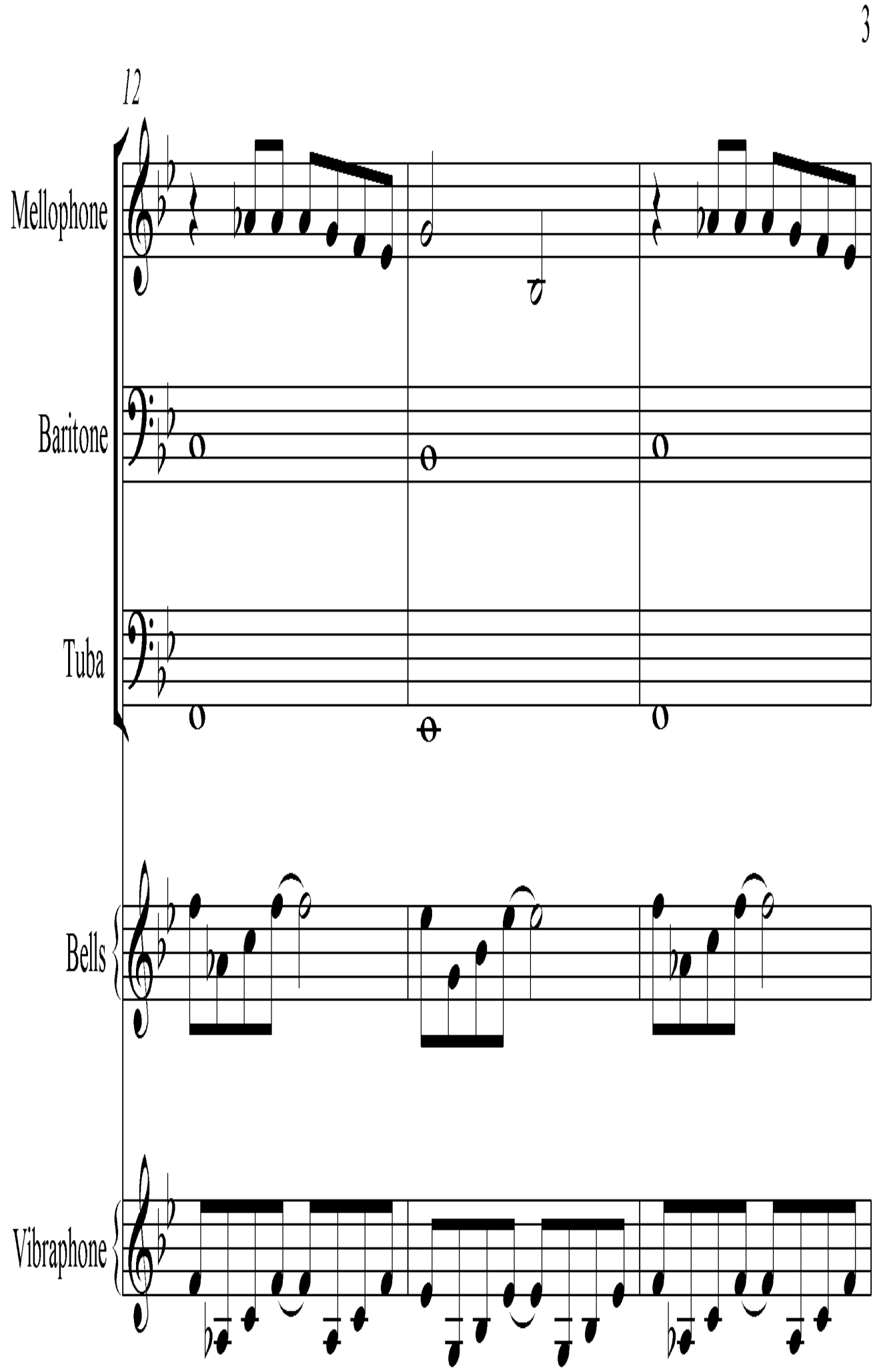


4
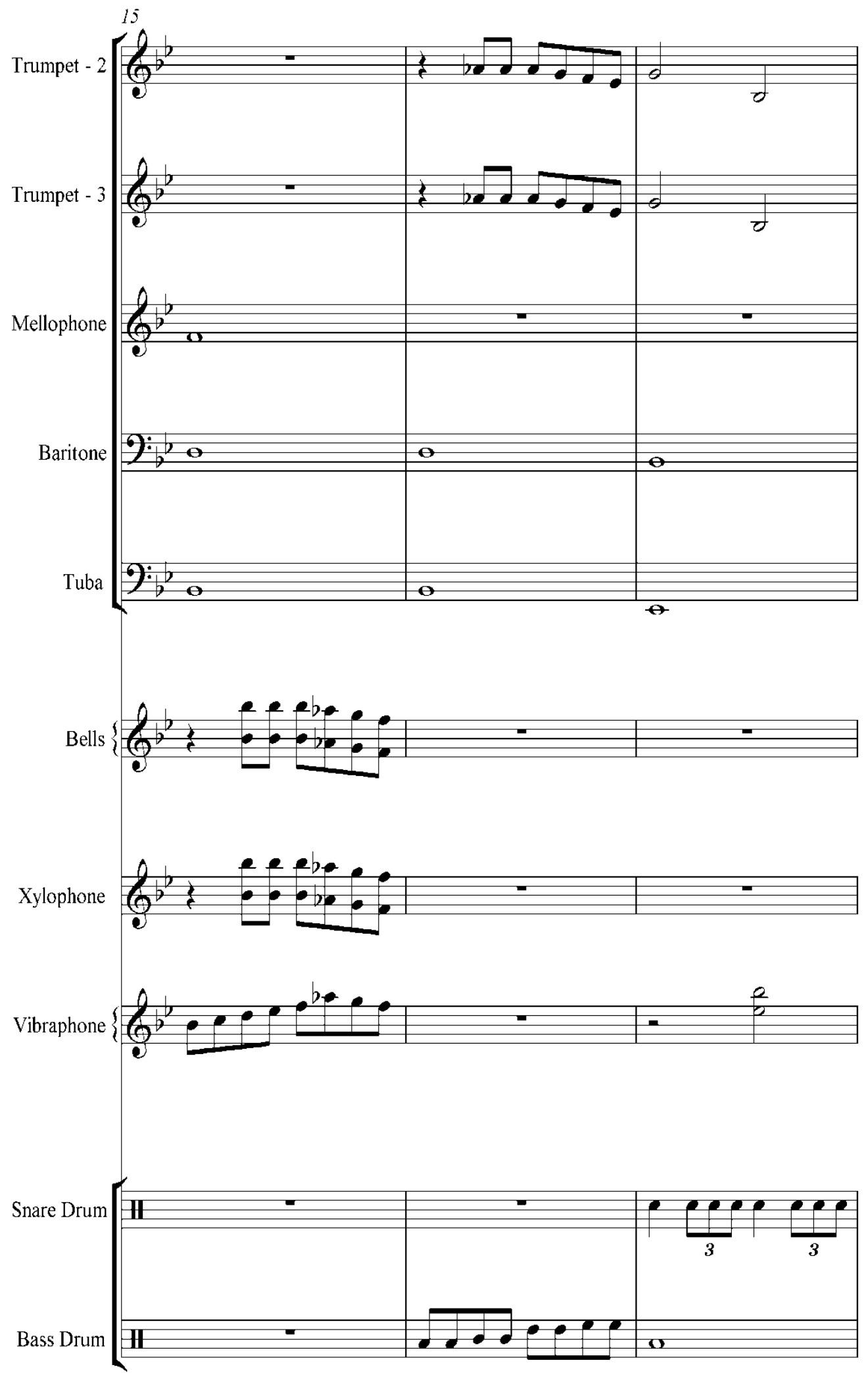


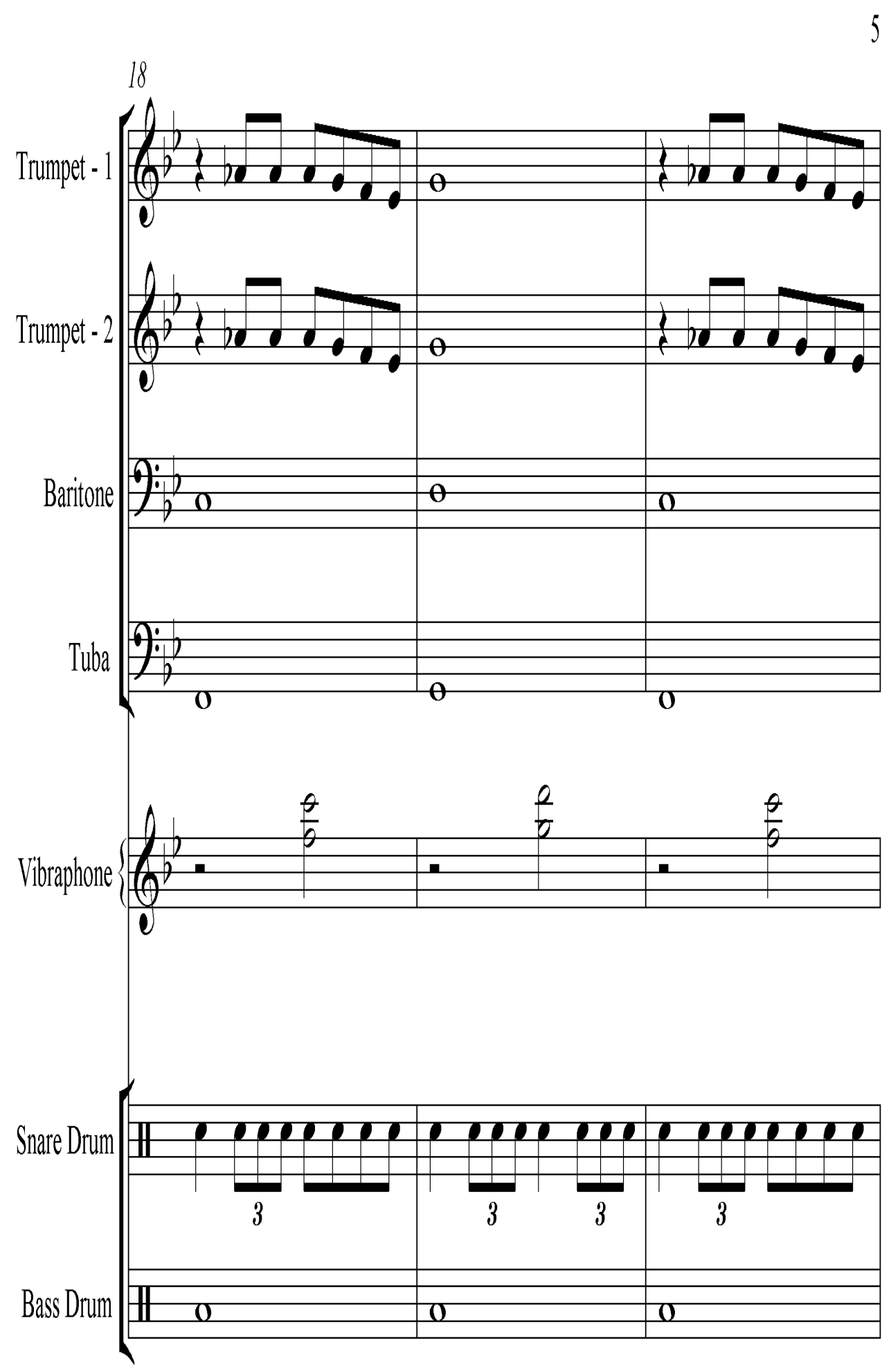




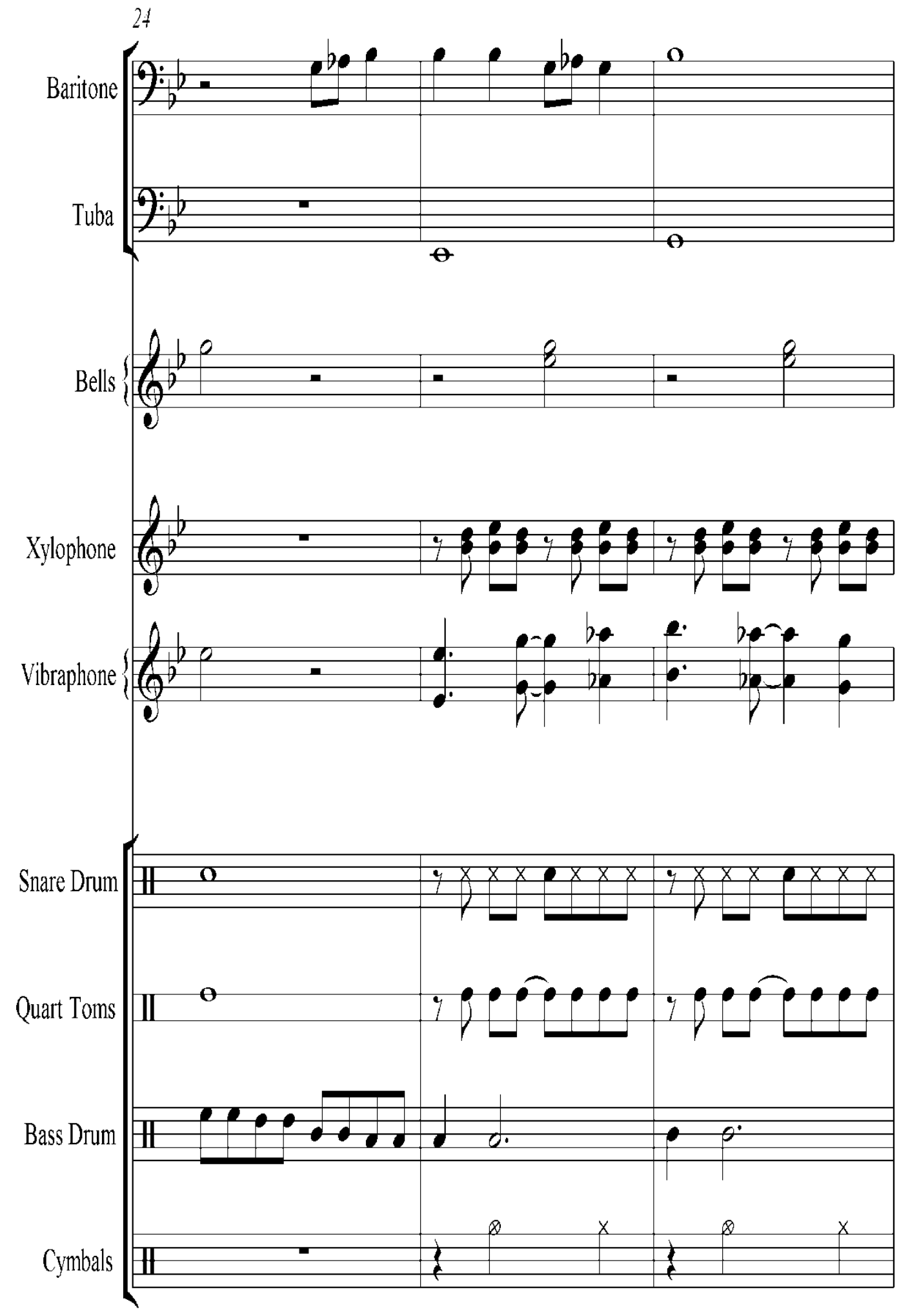


8

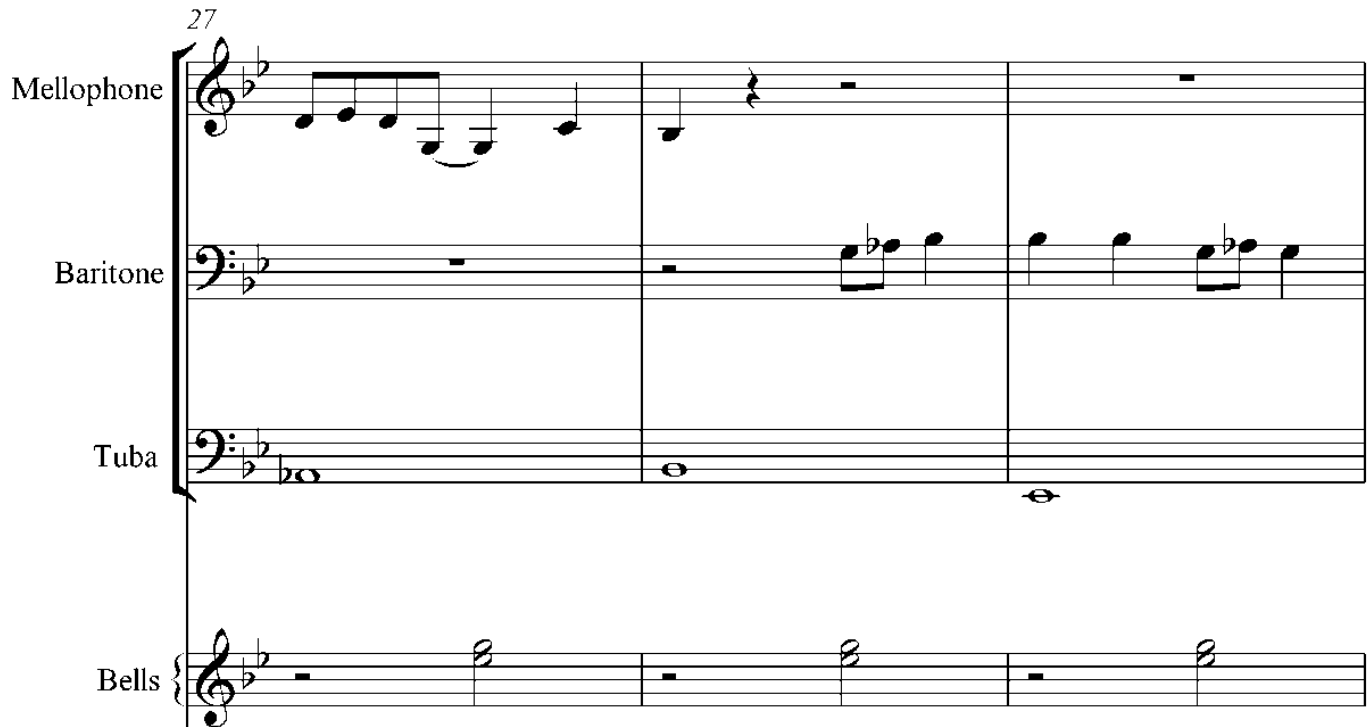

Xylophone $\left(\mathrm{Q}^{b^{b}}\right.$;
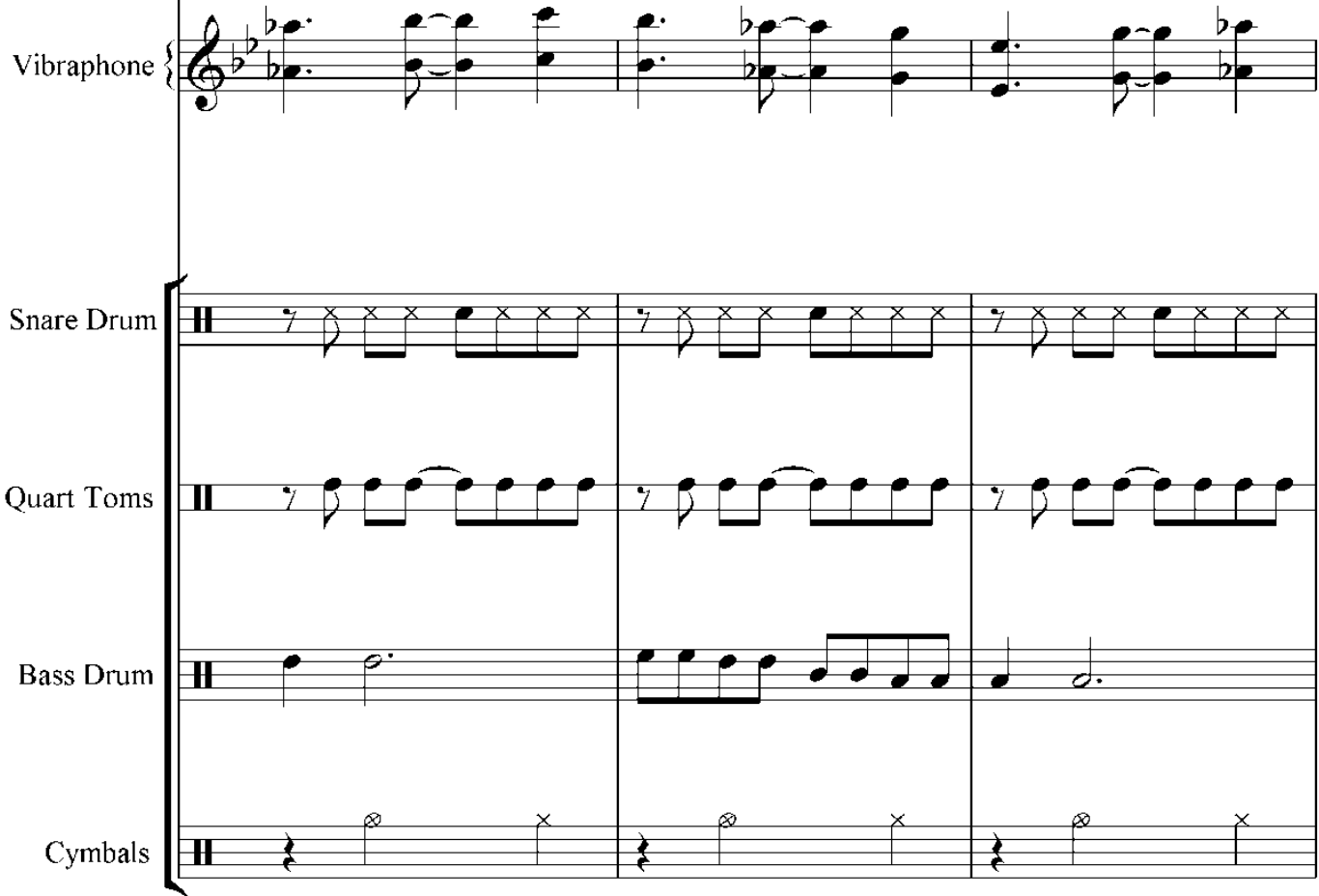


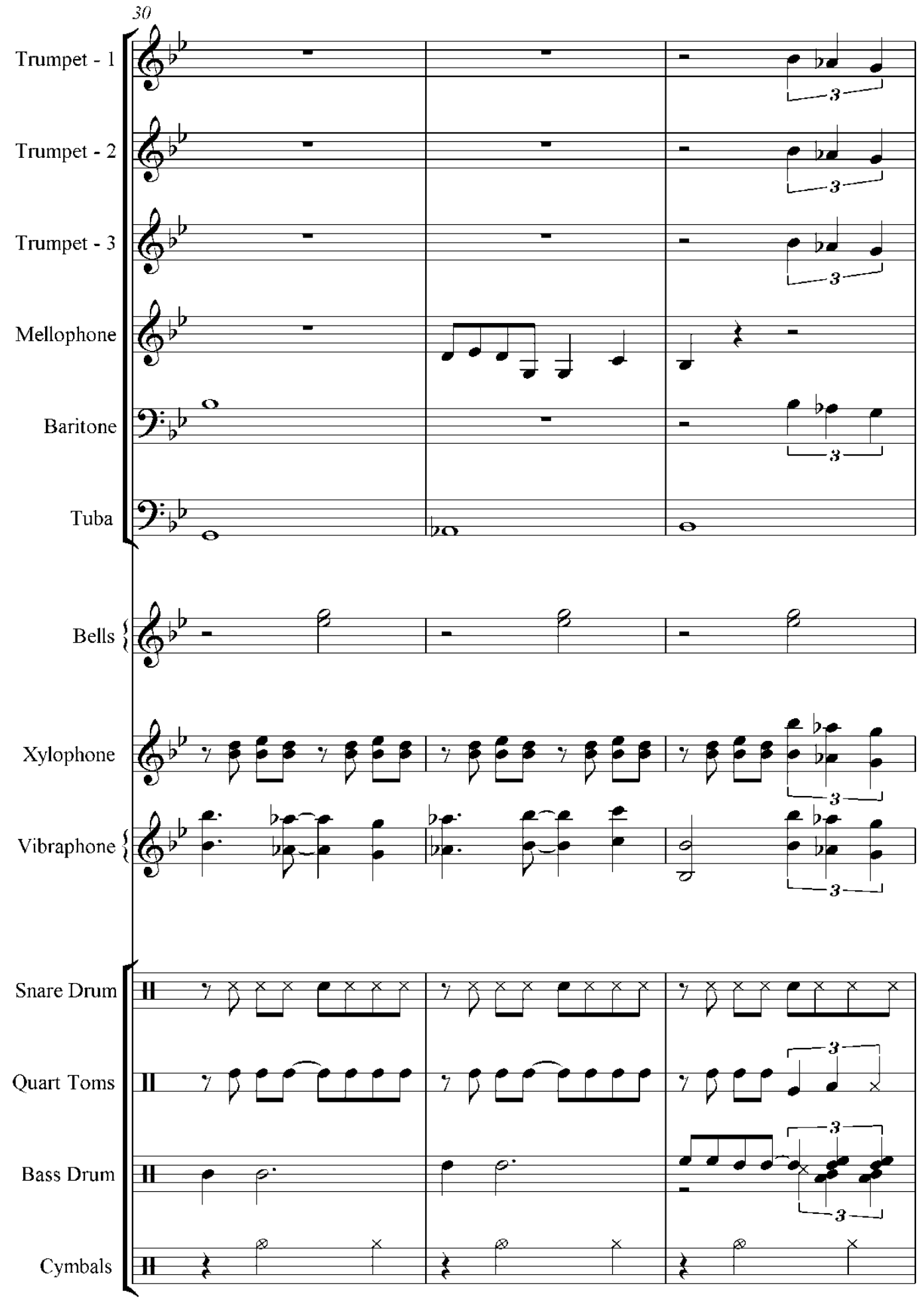




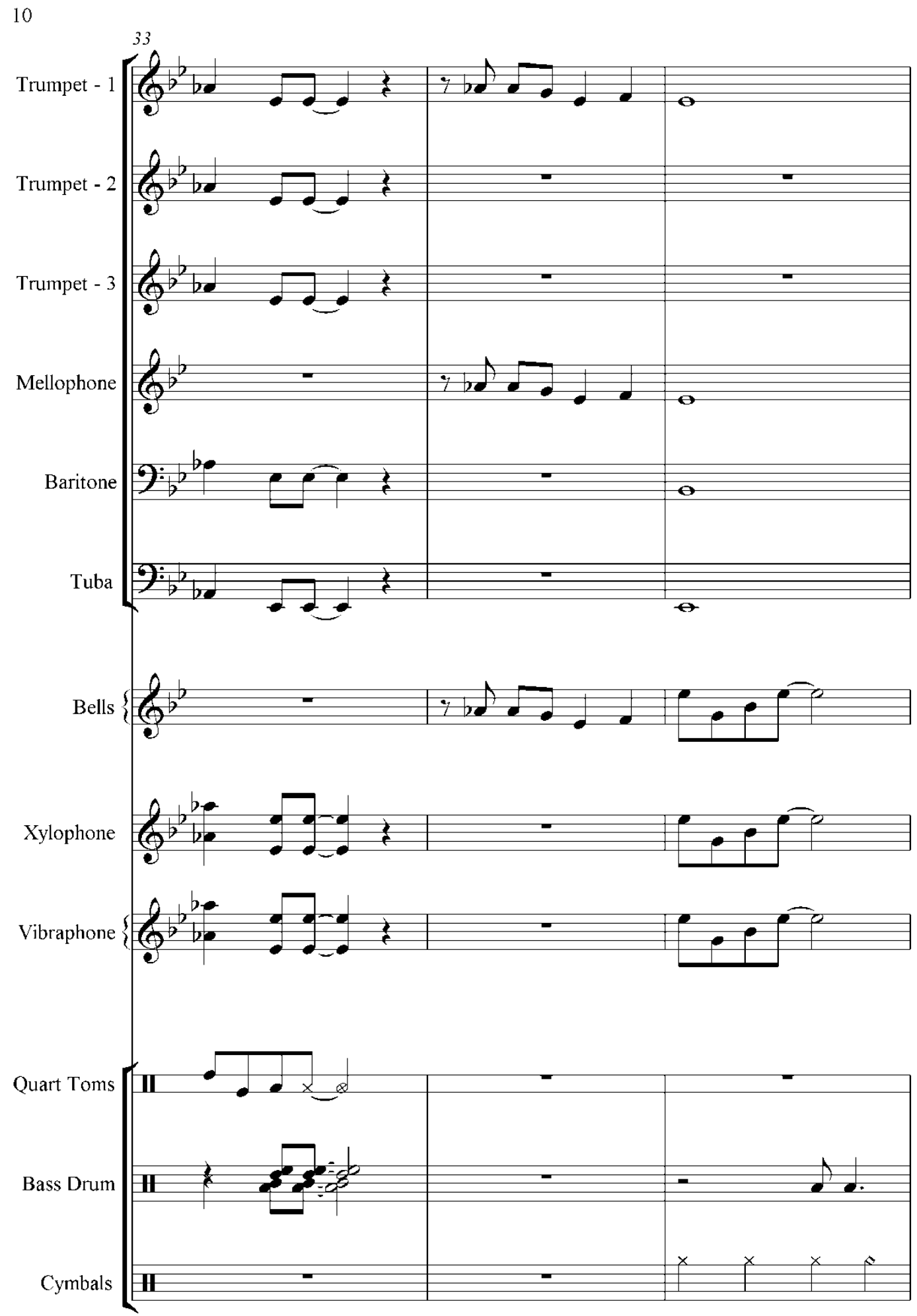



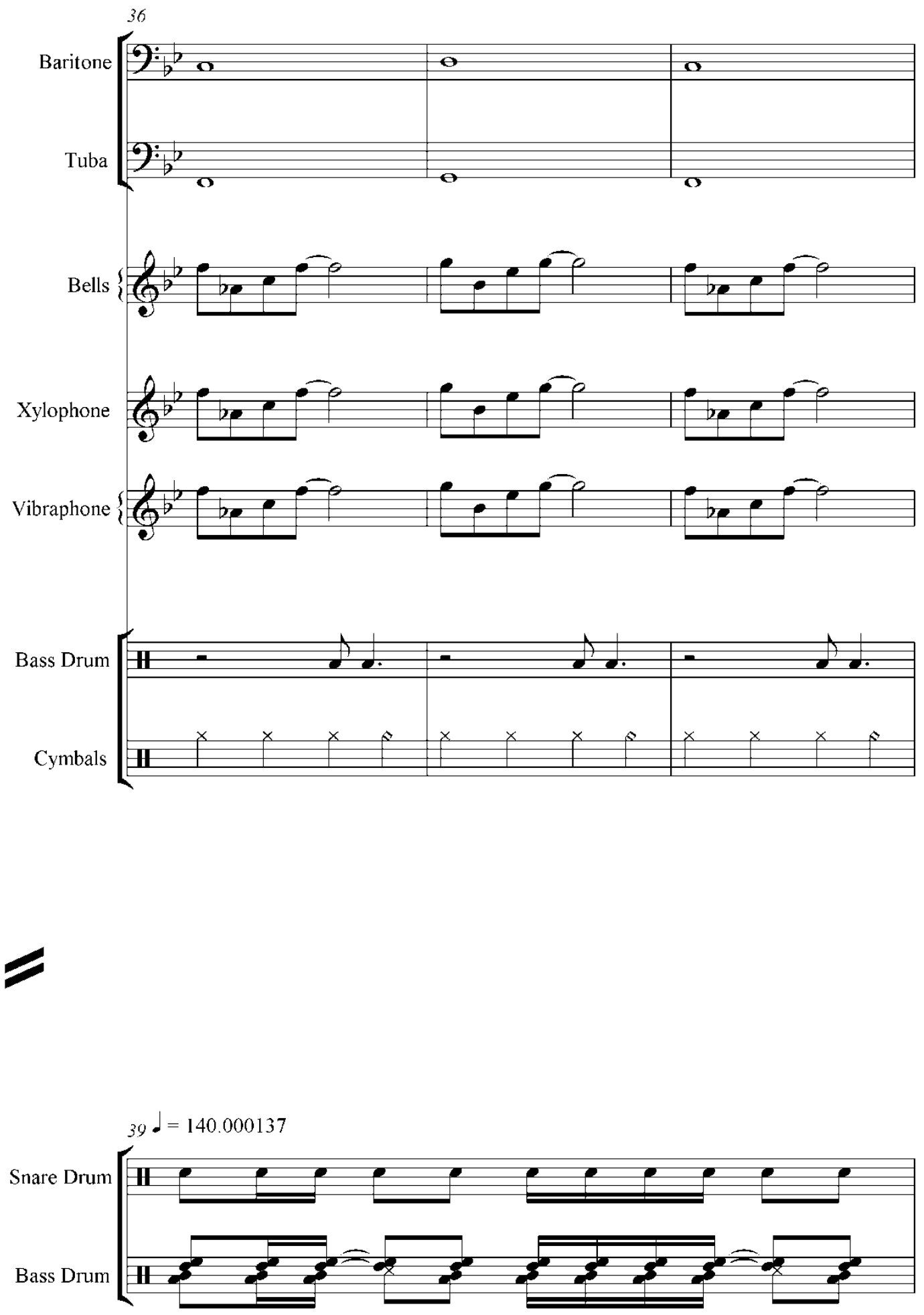

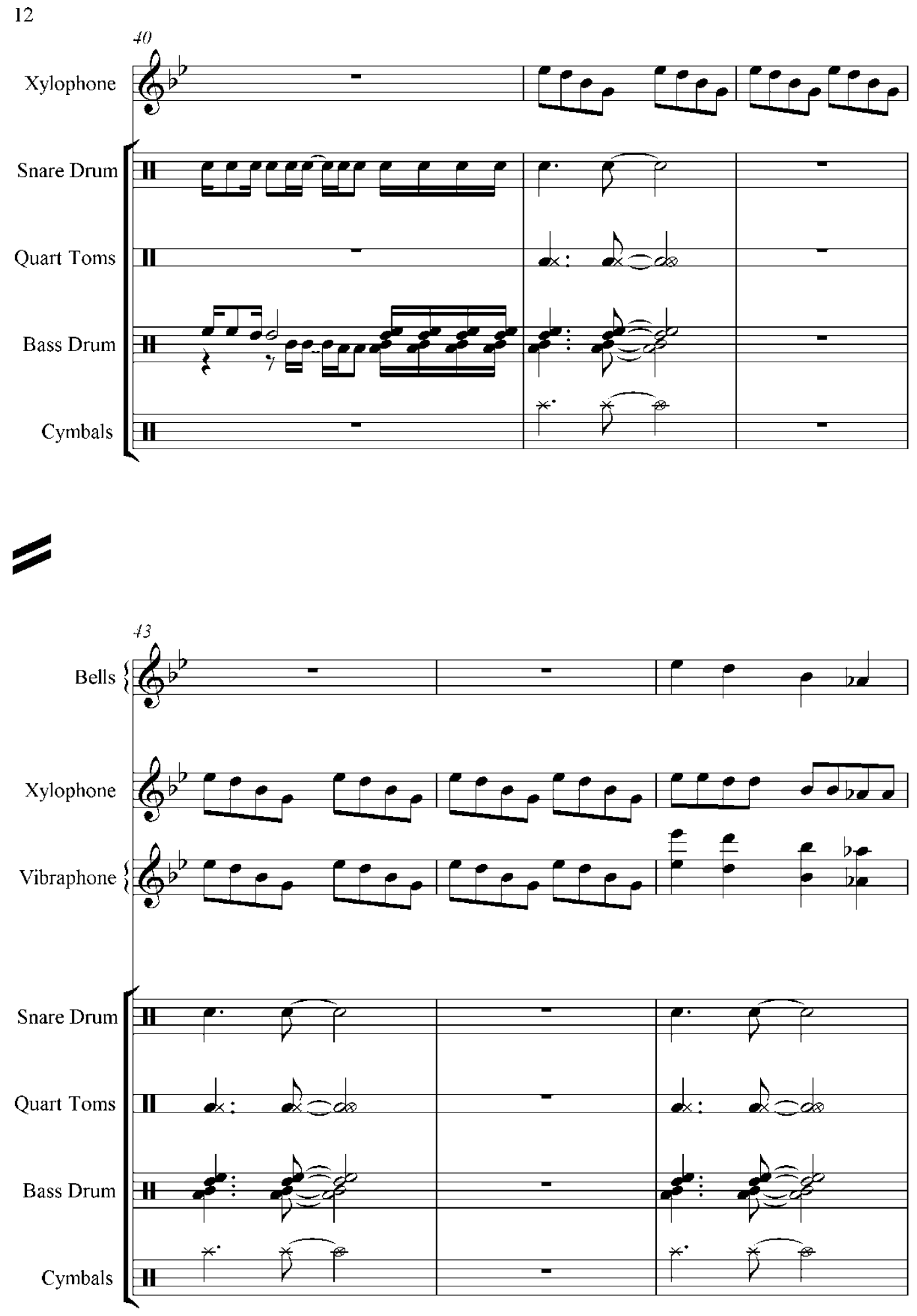


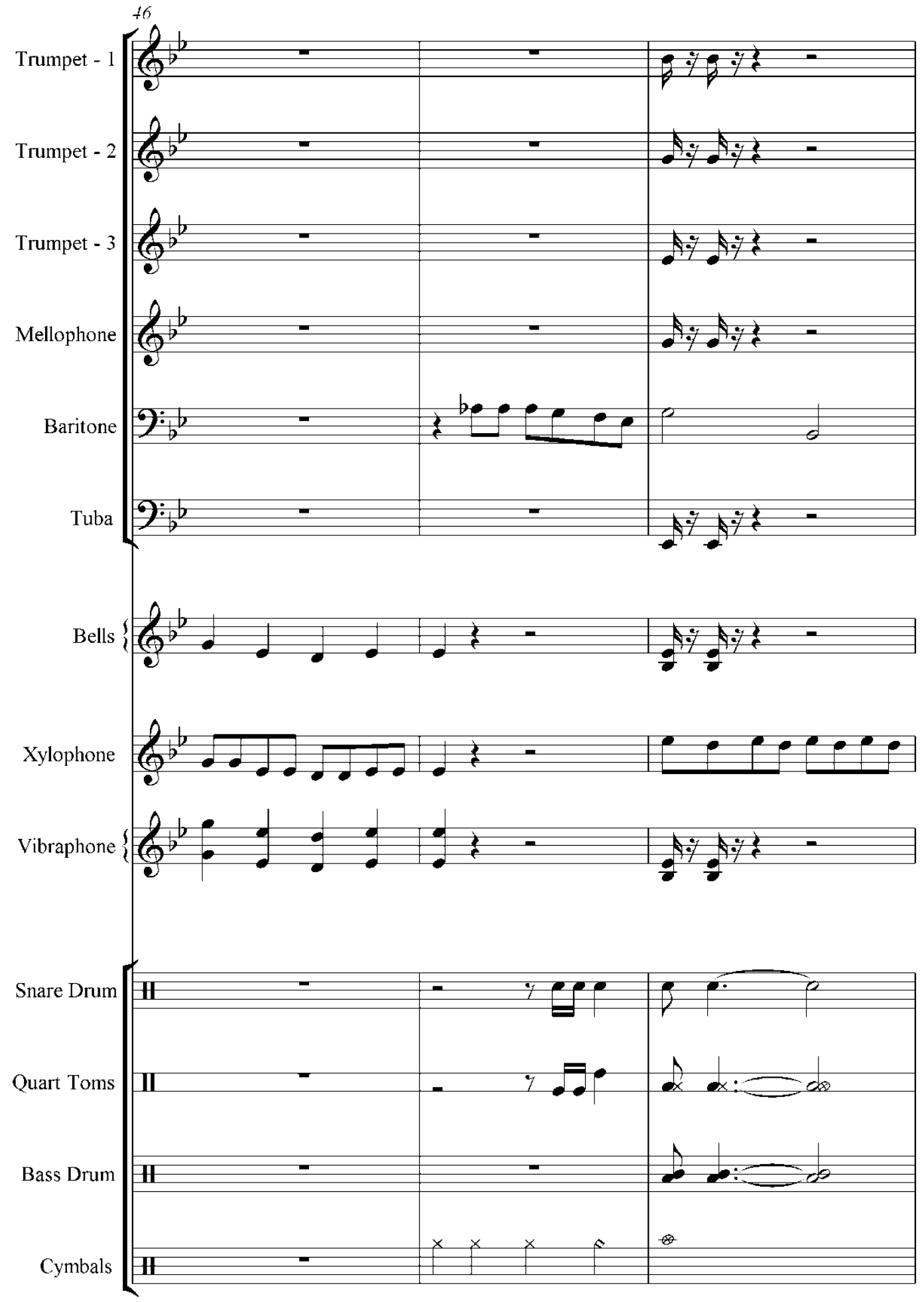




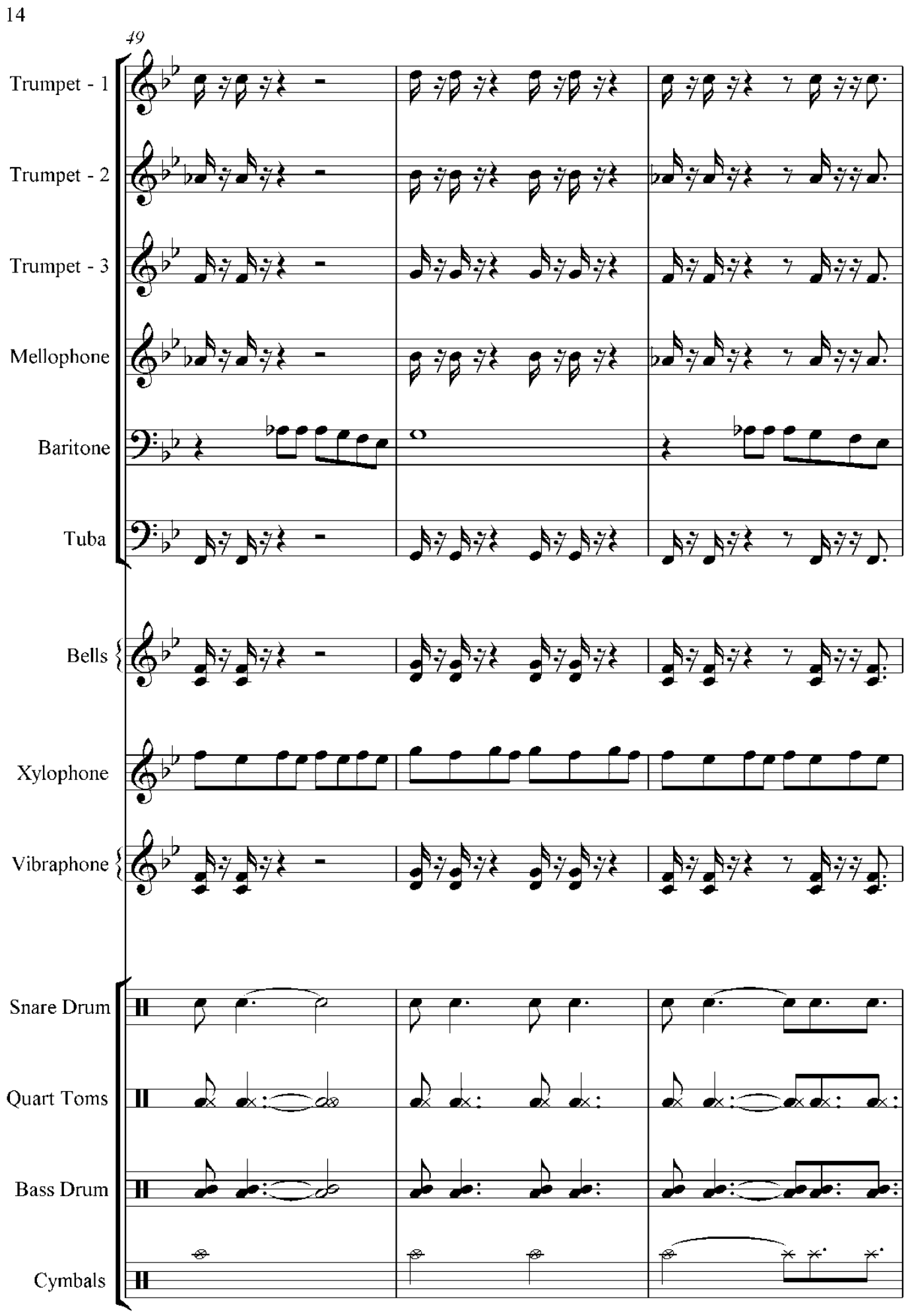




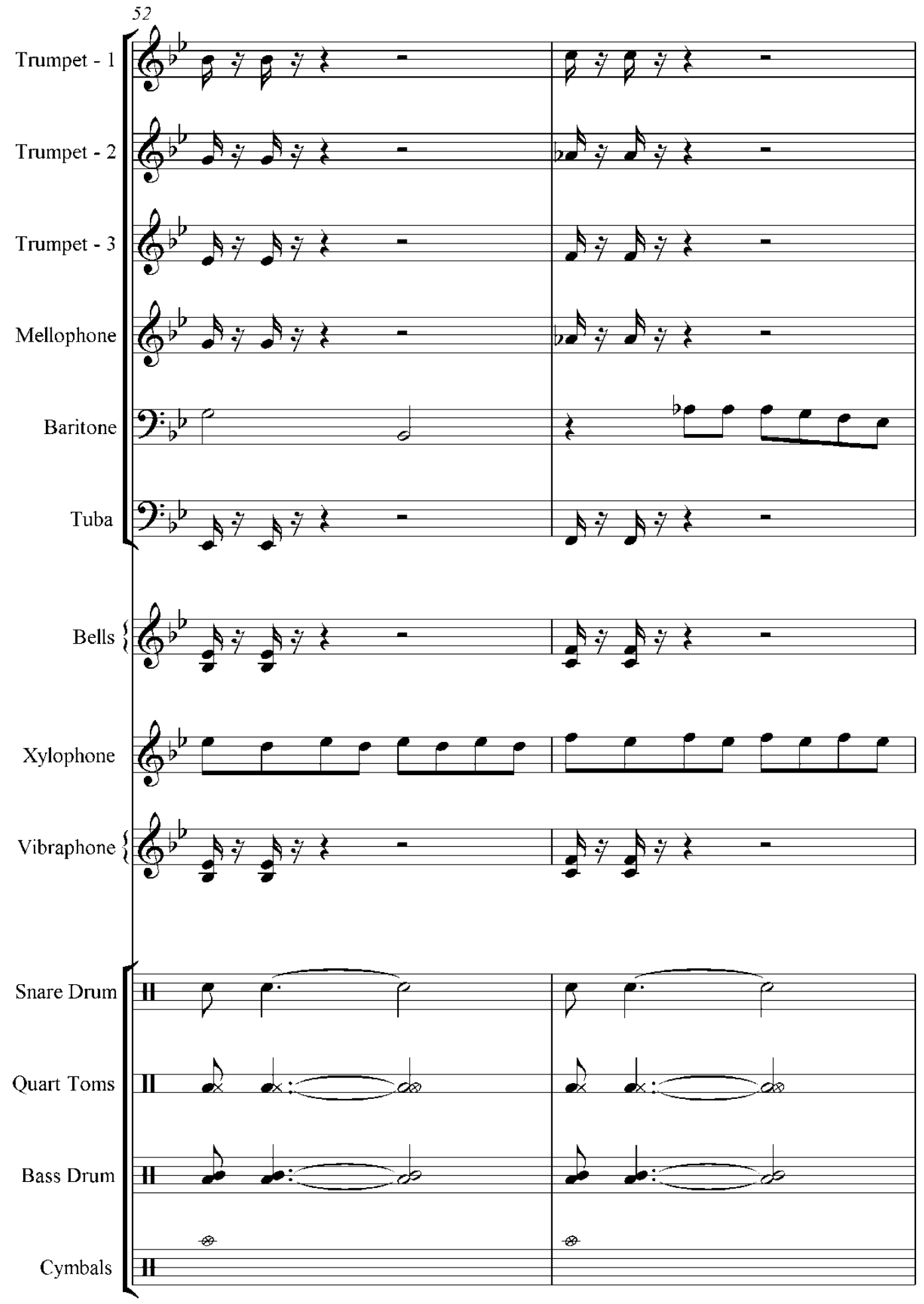




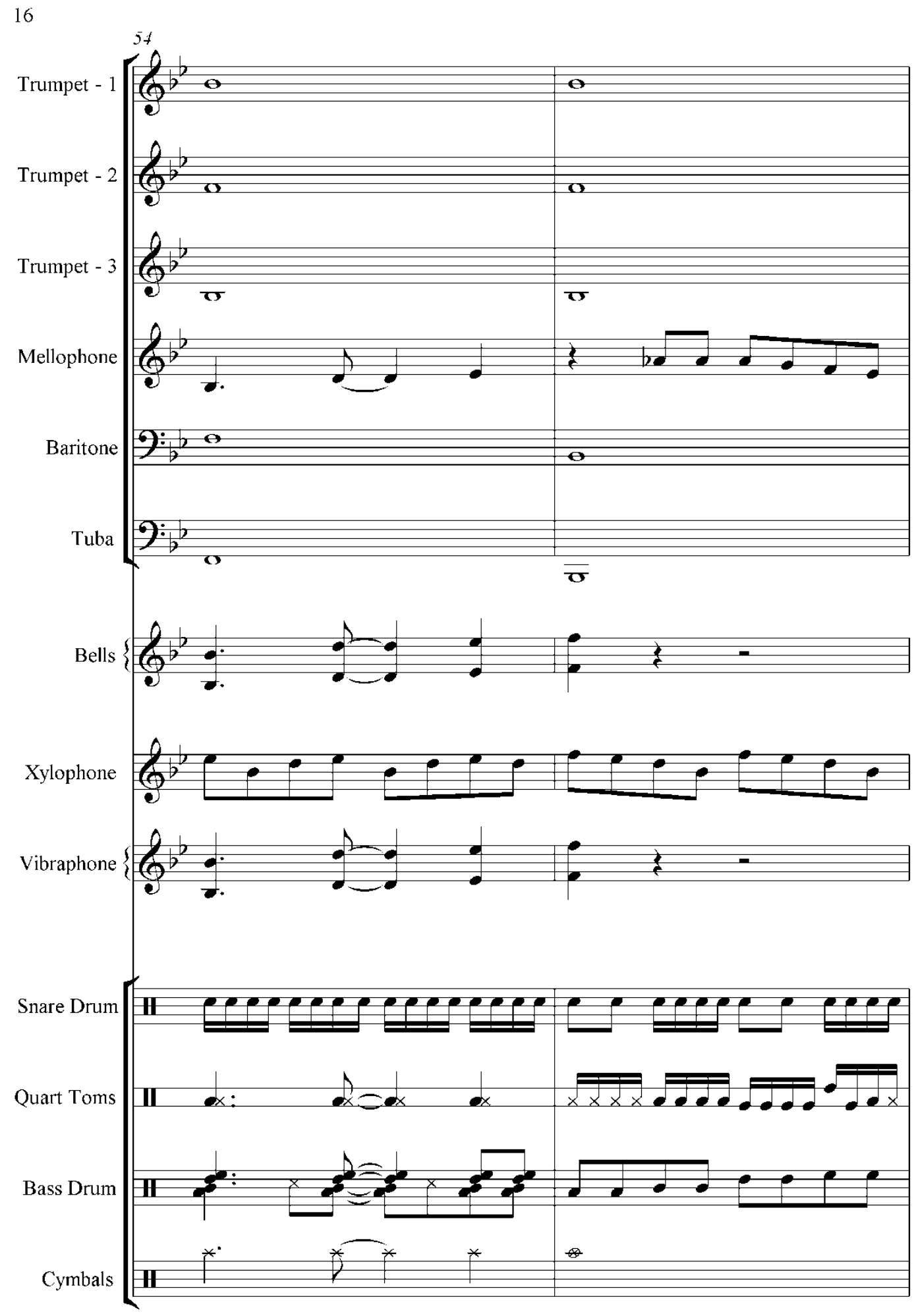




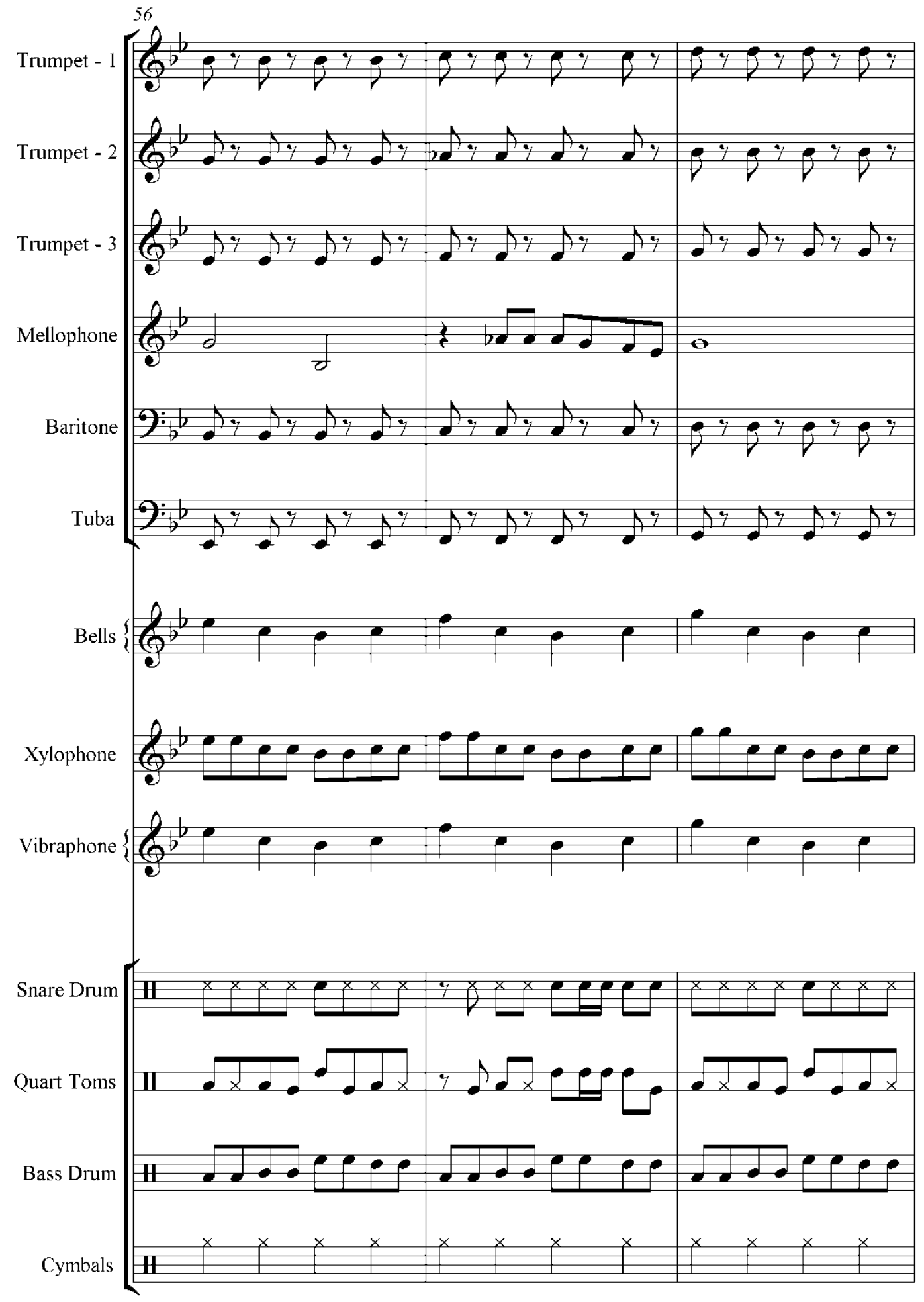




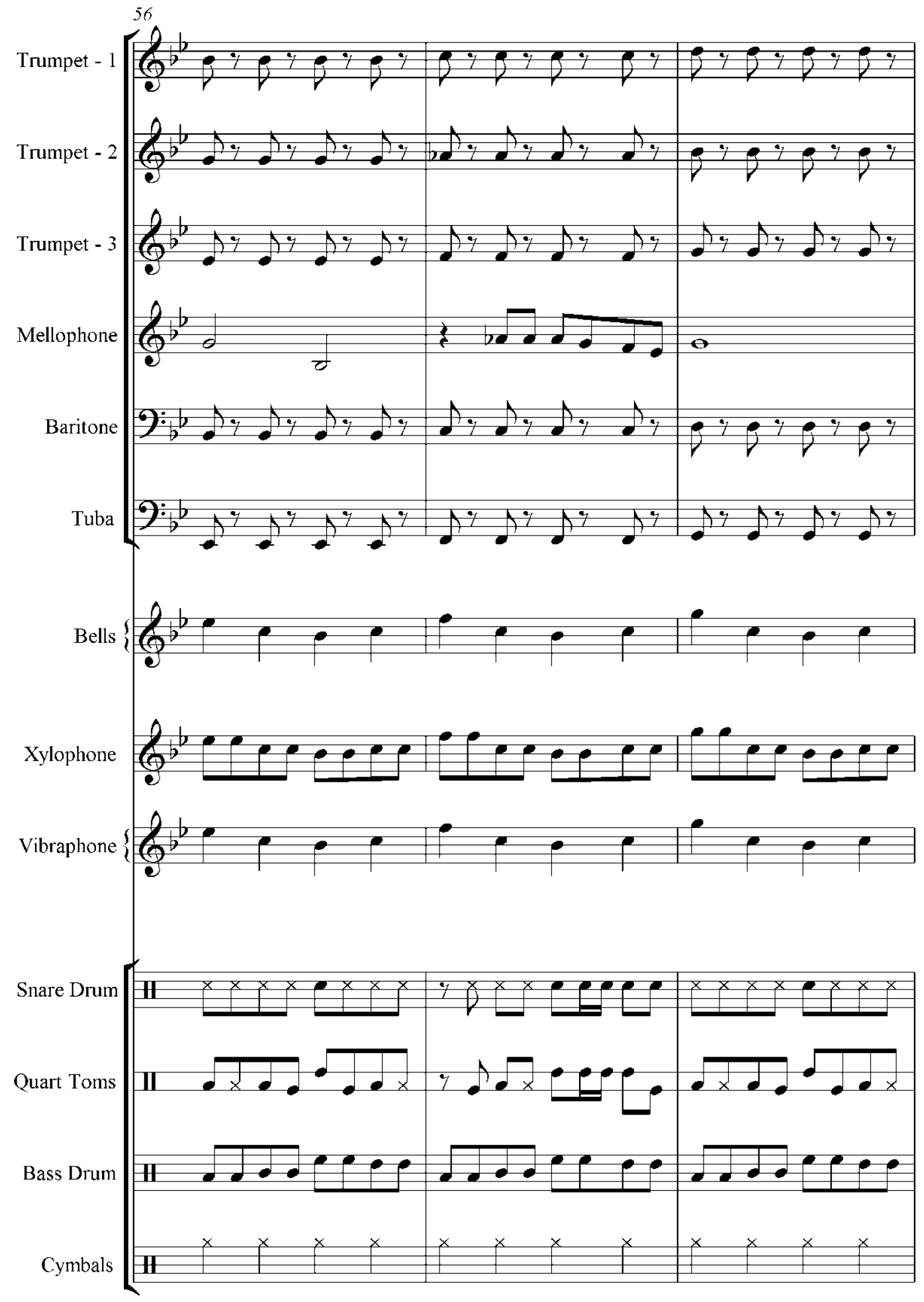


18

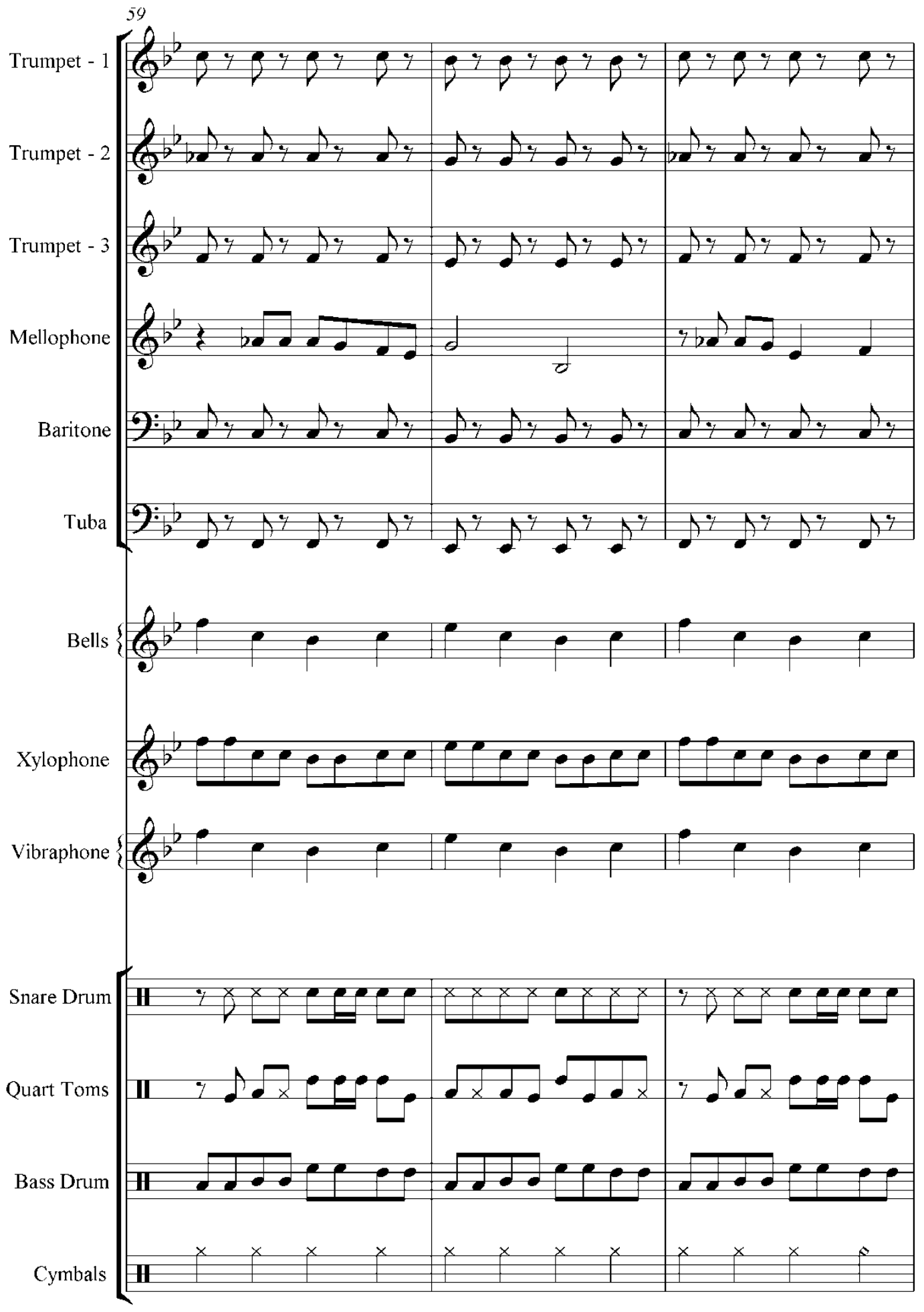




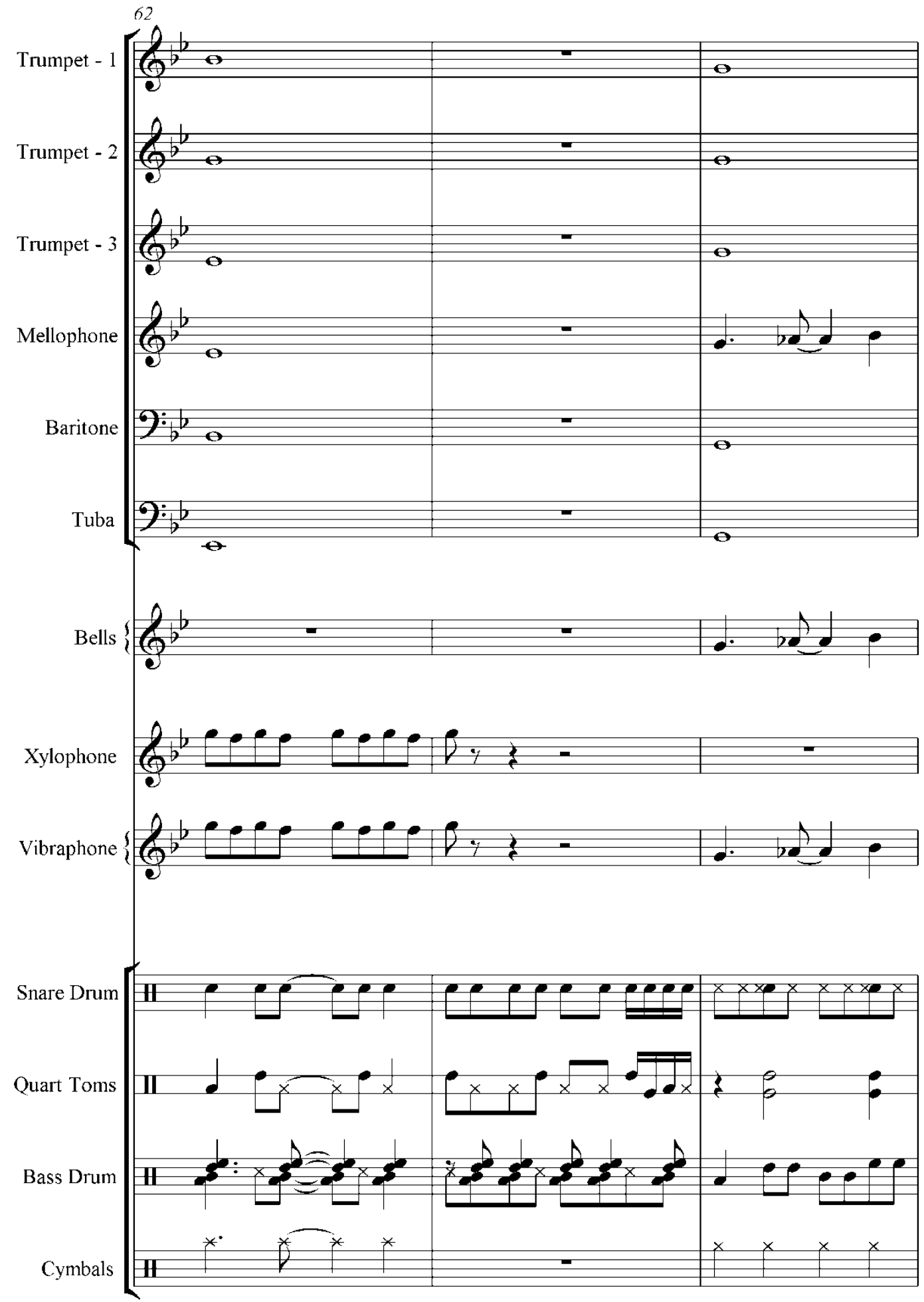




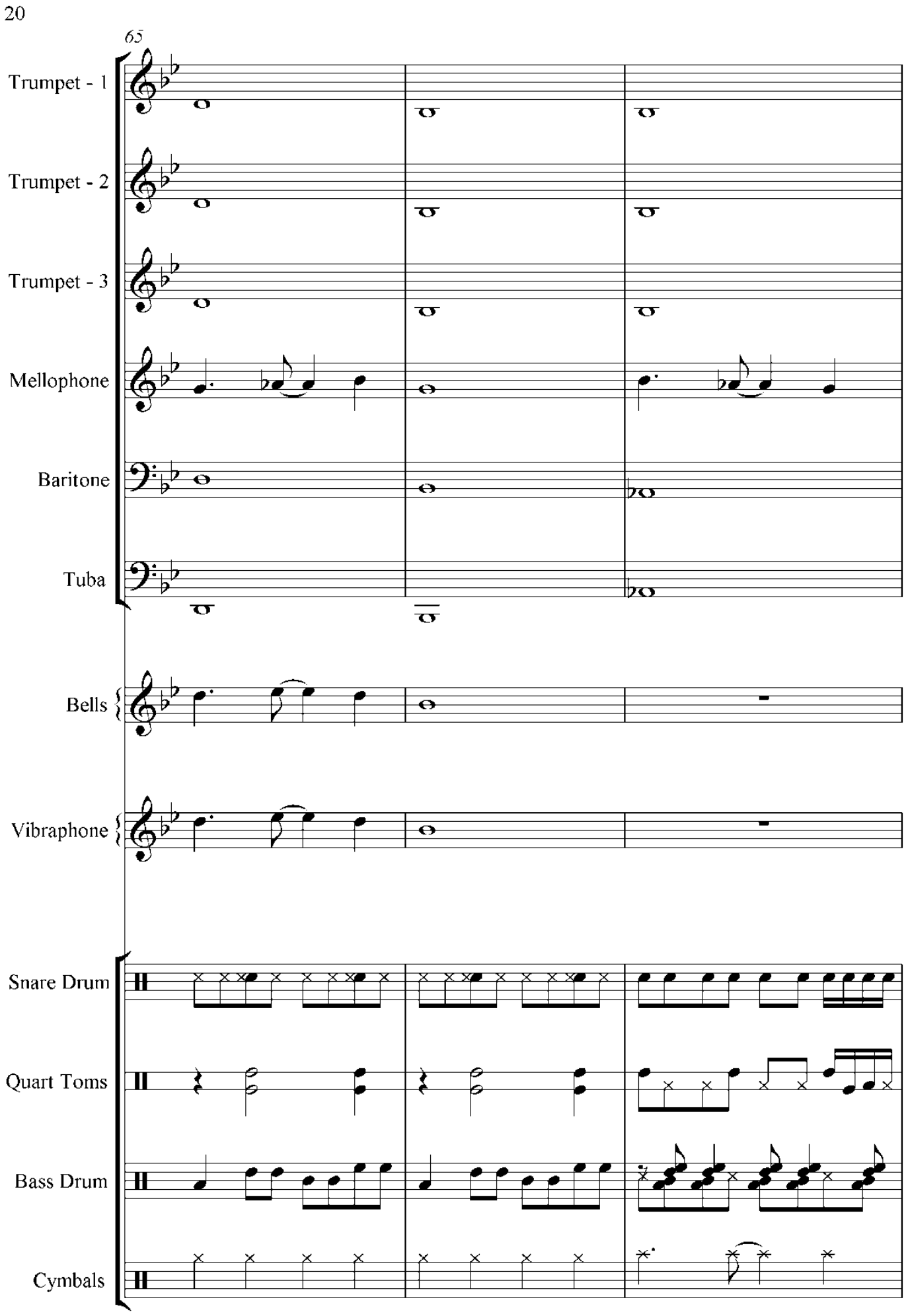




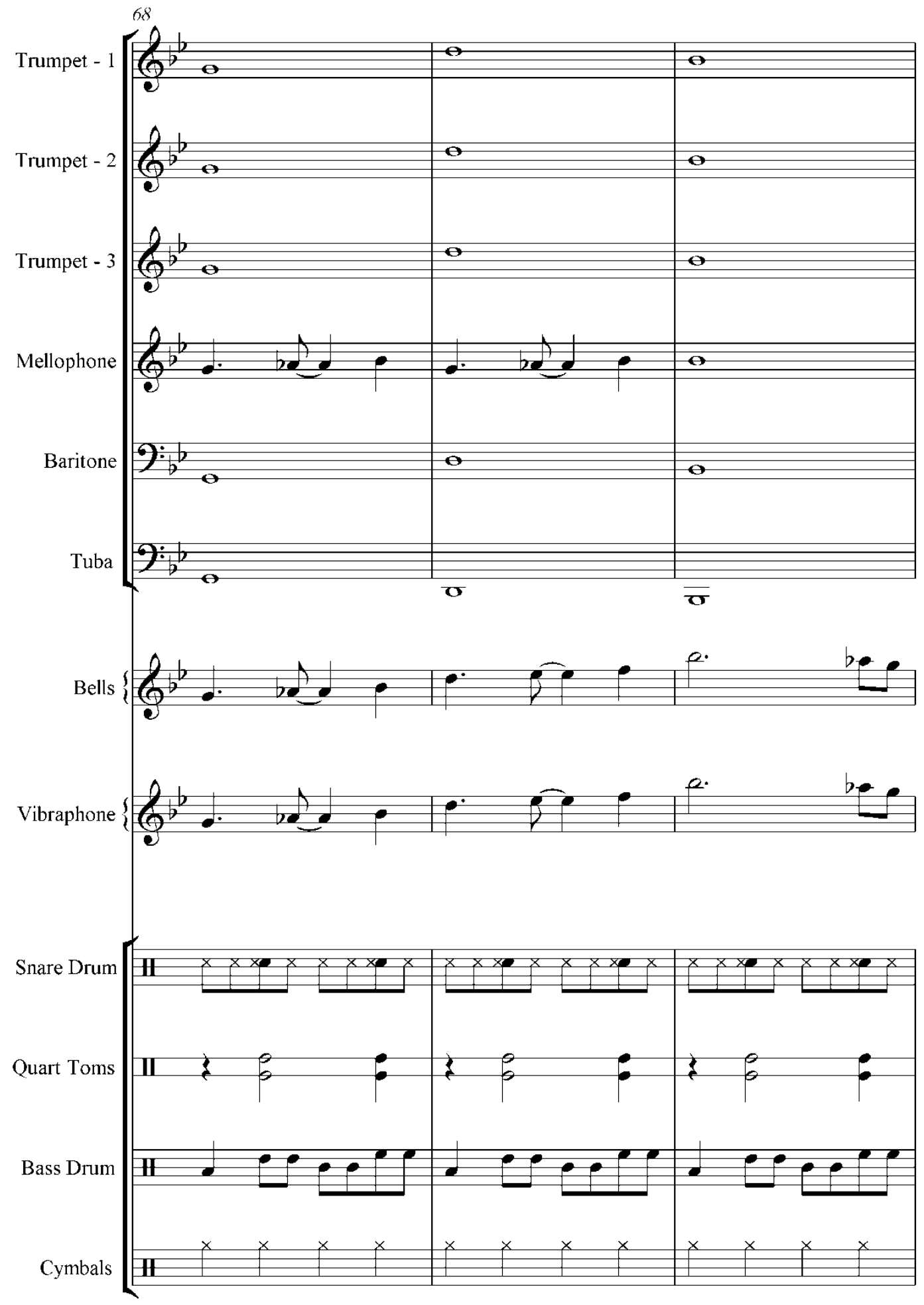




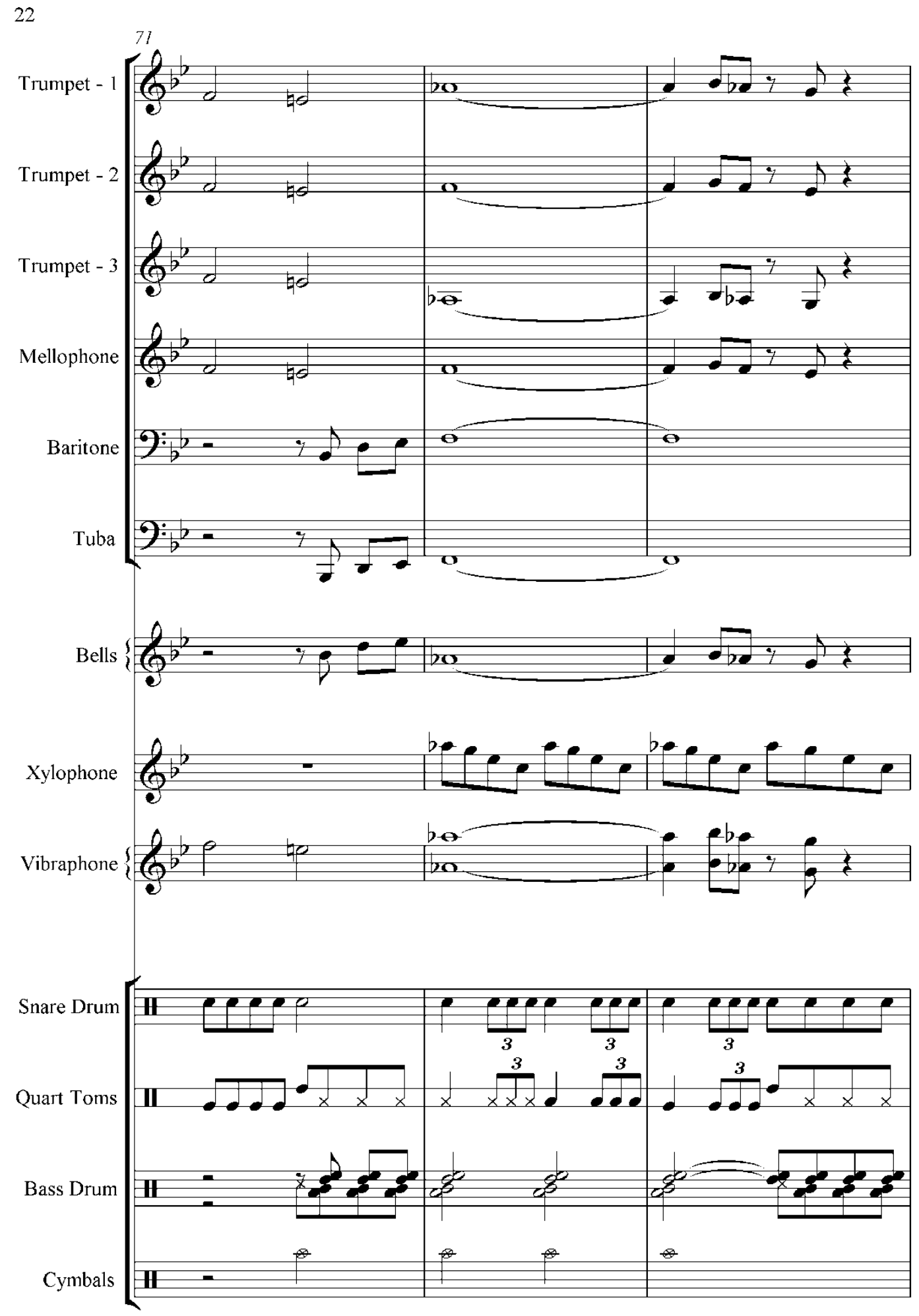




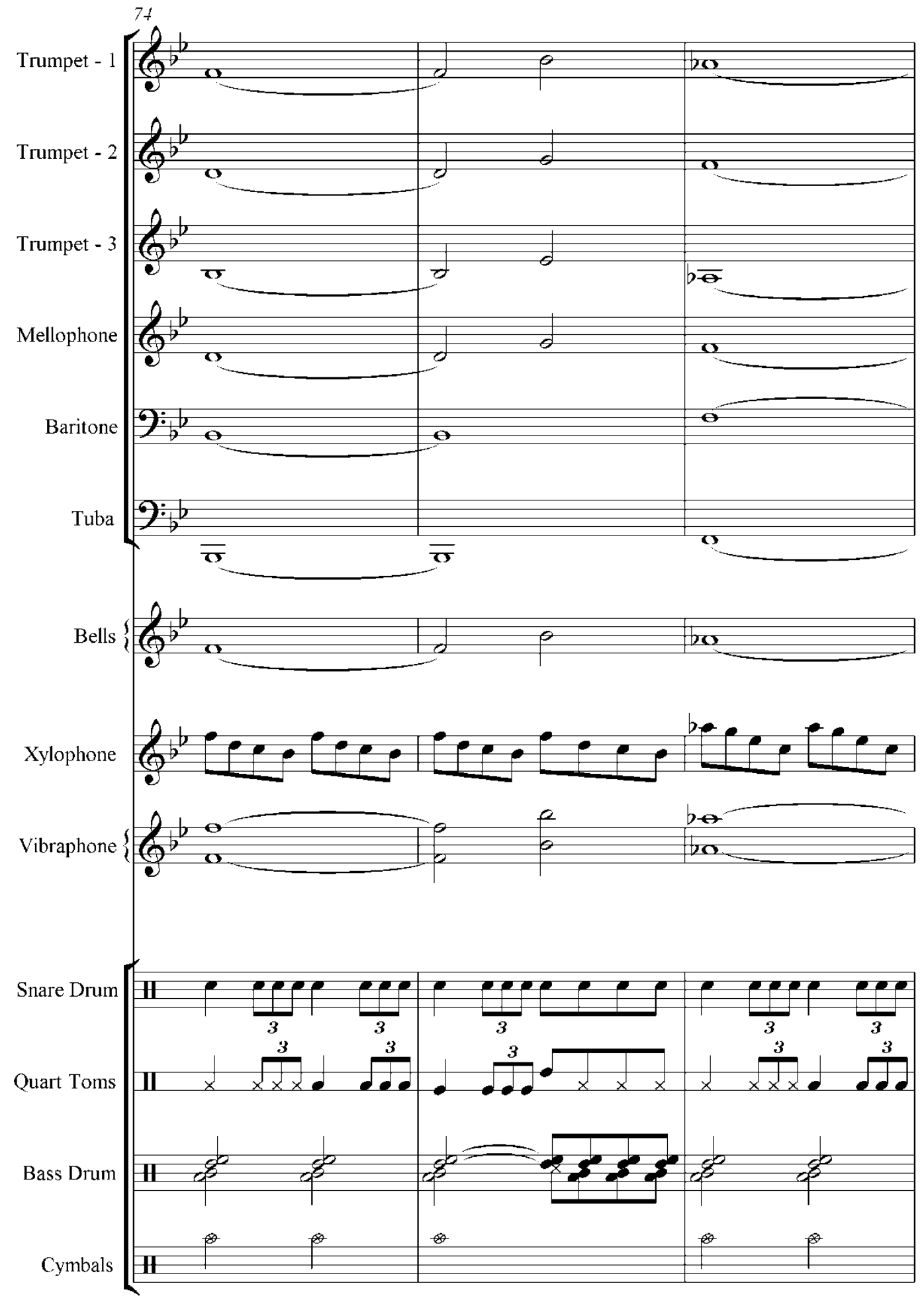




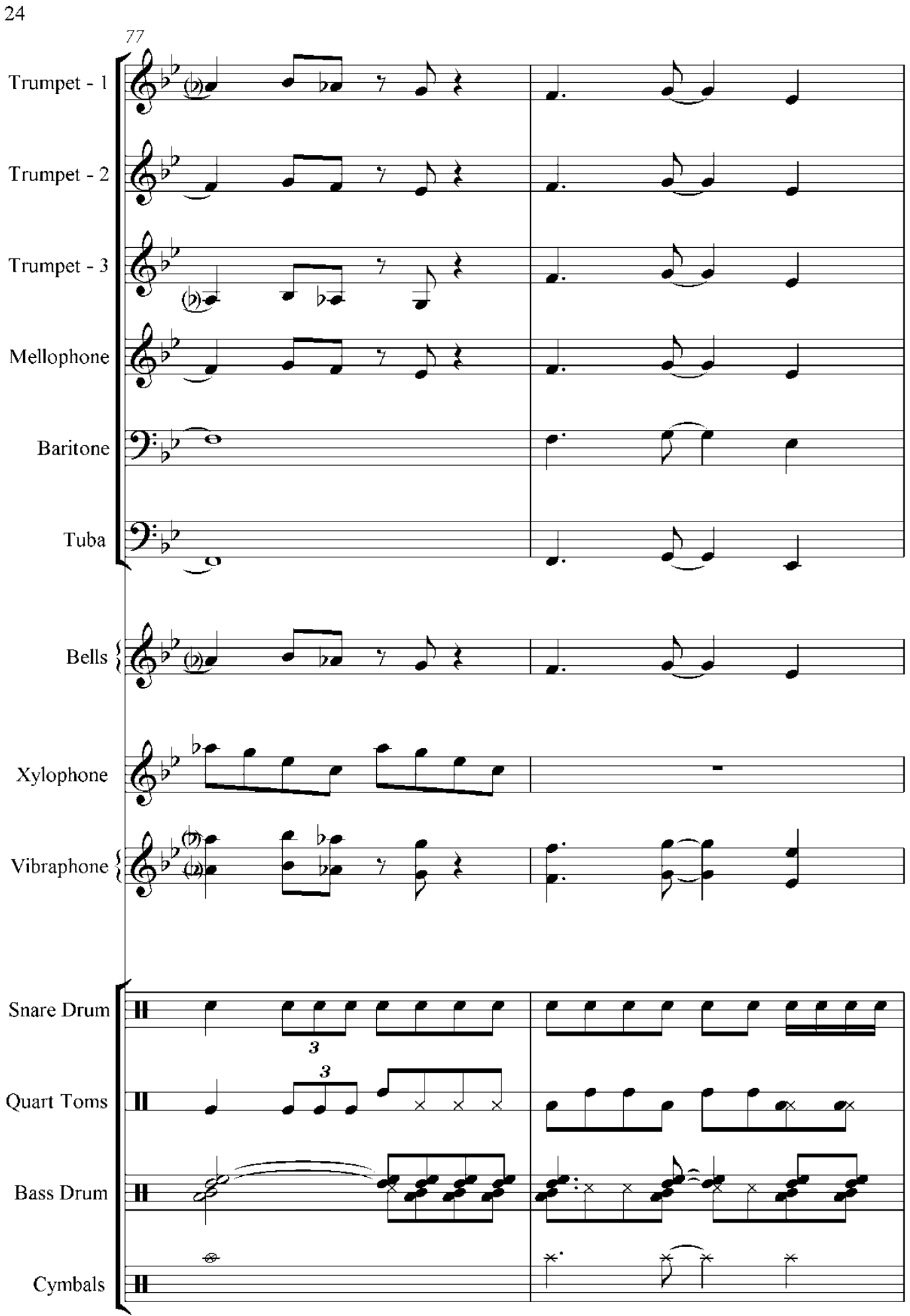




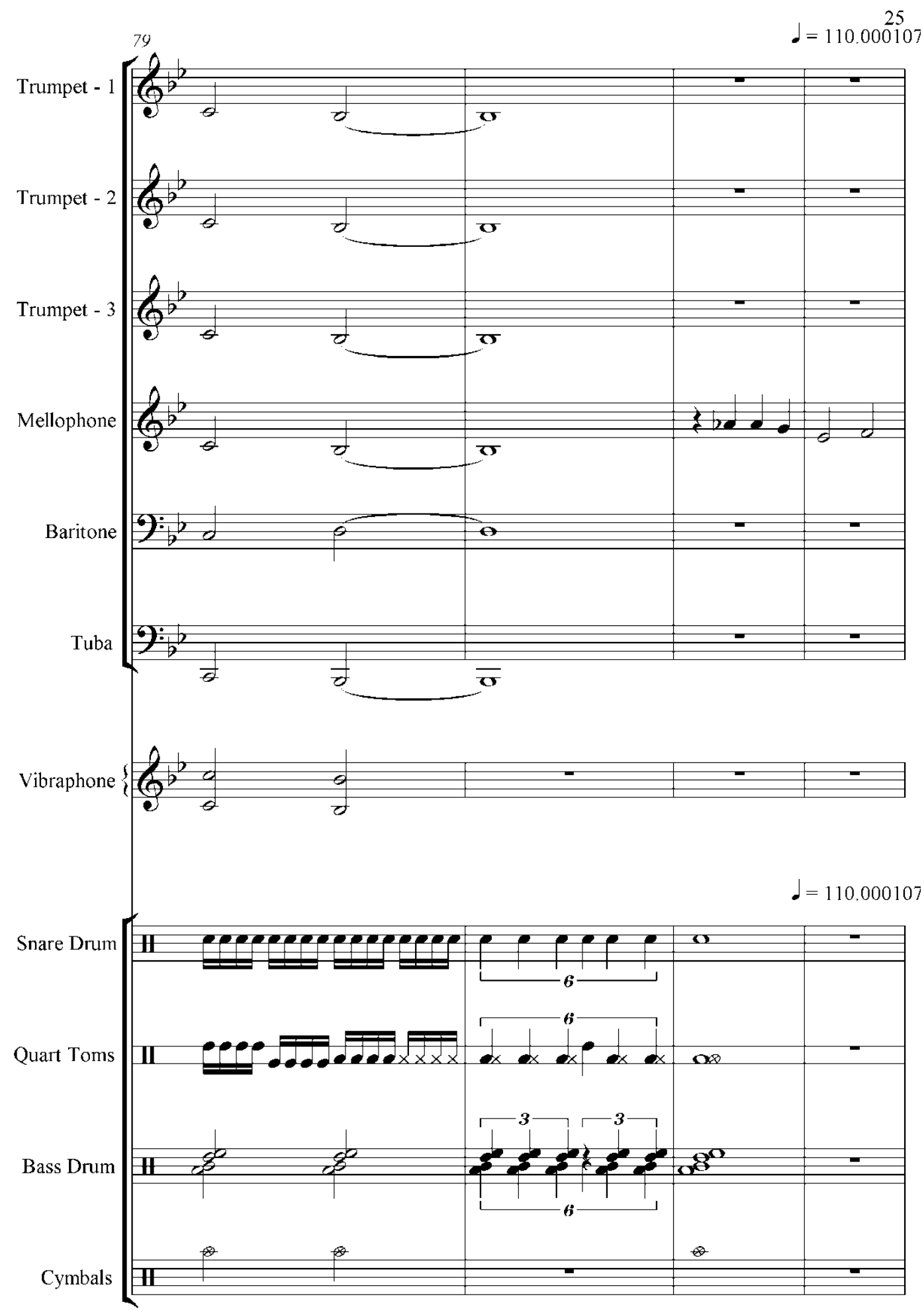



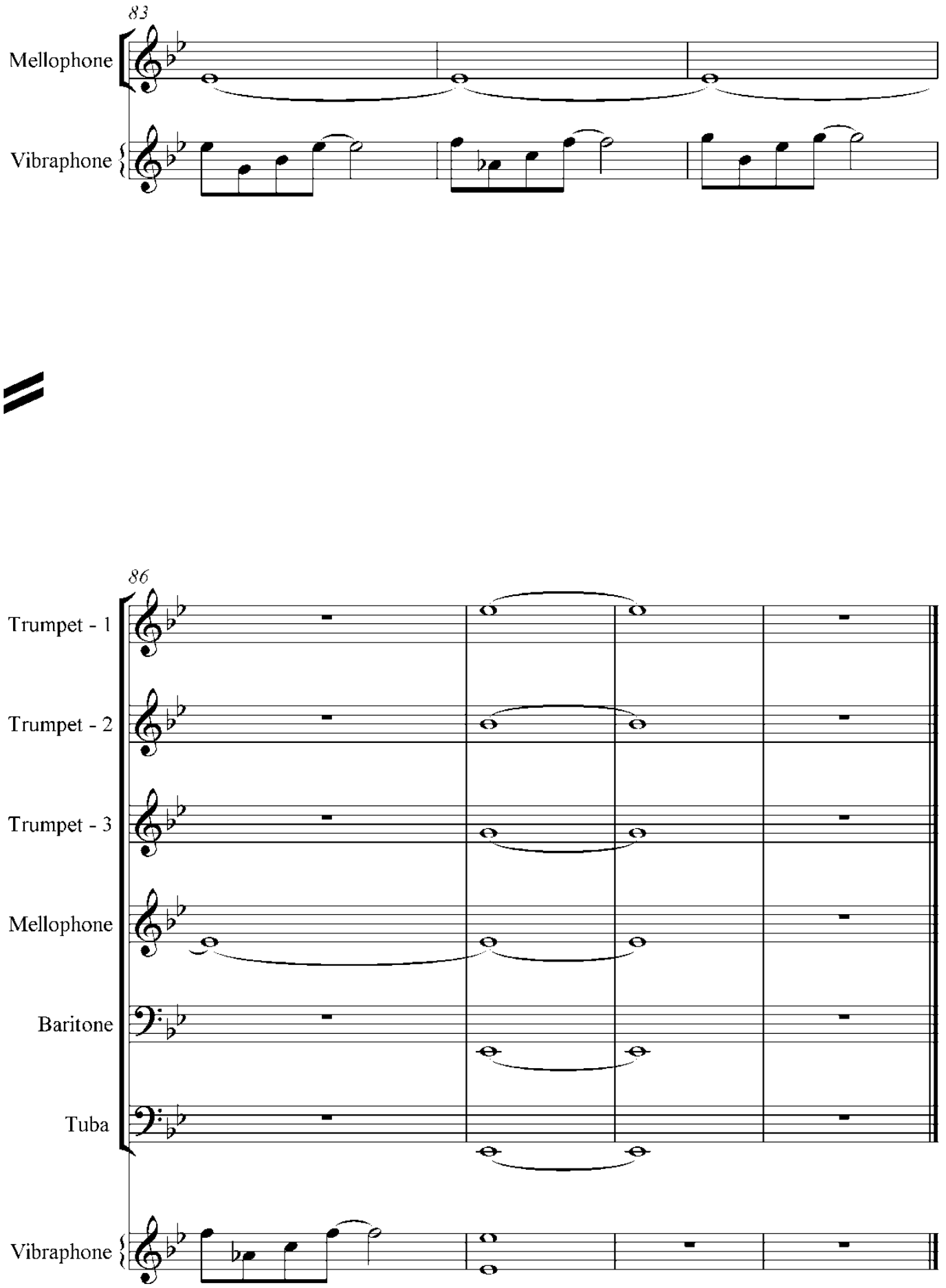


\section{CHART DISPLAY}




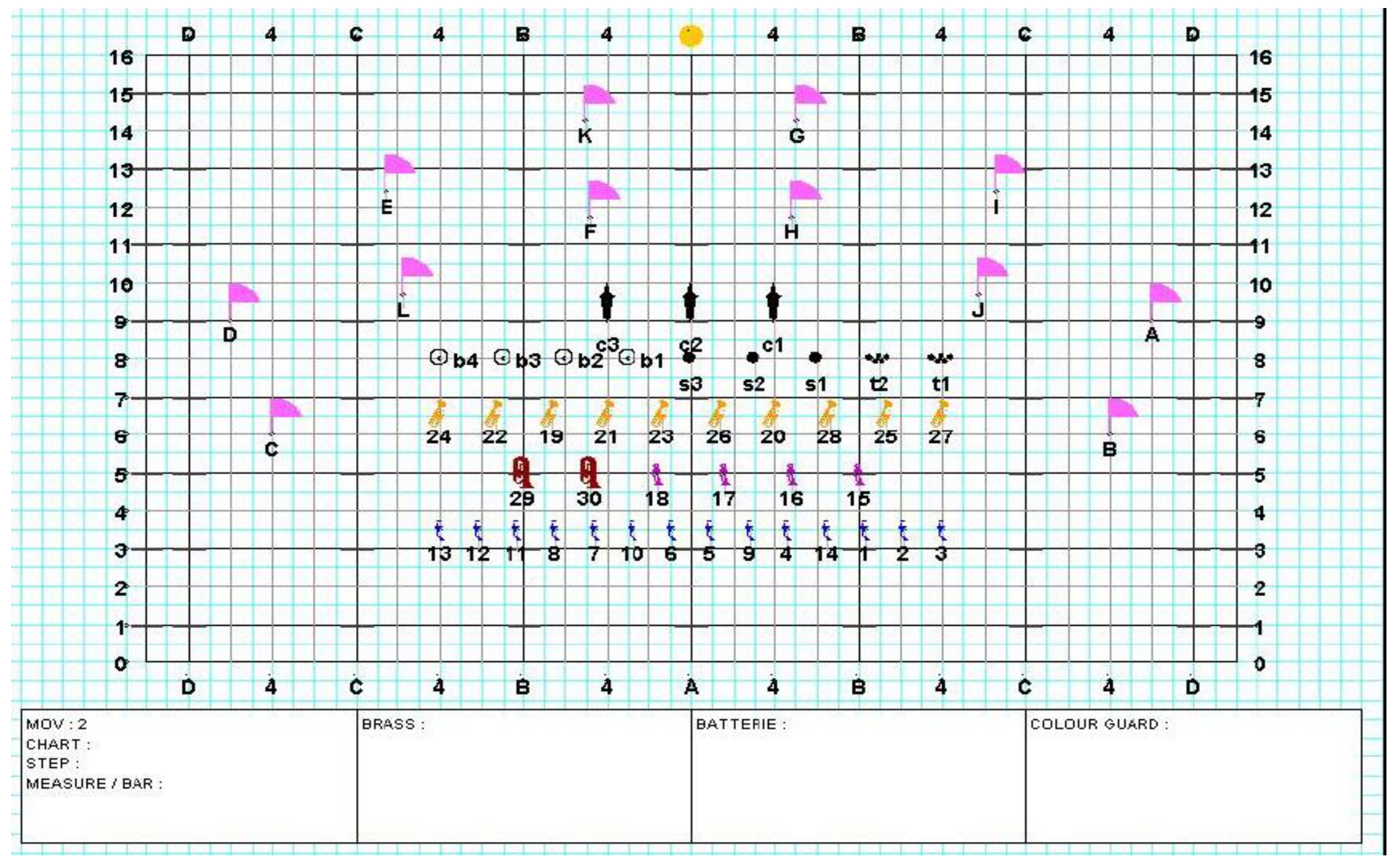




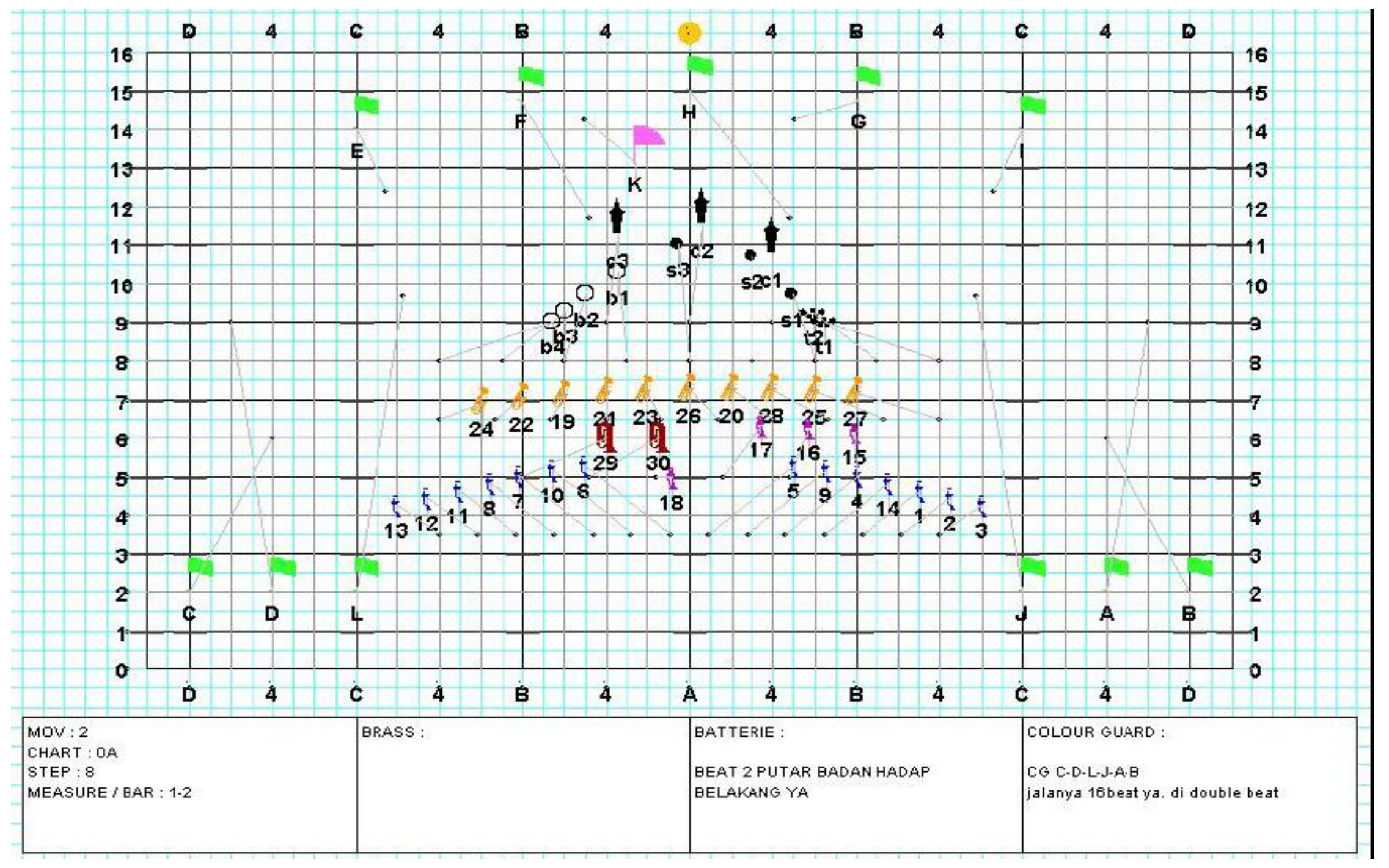




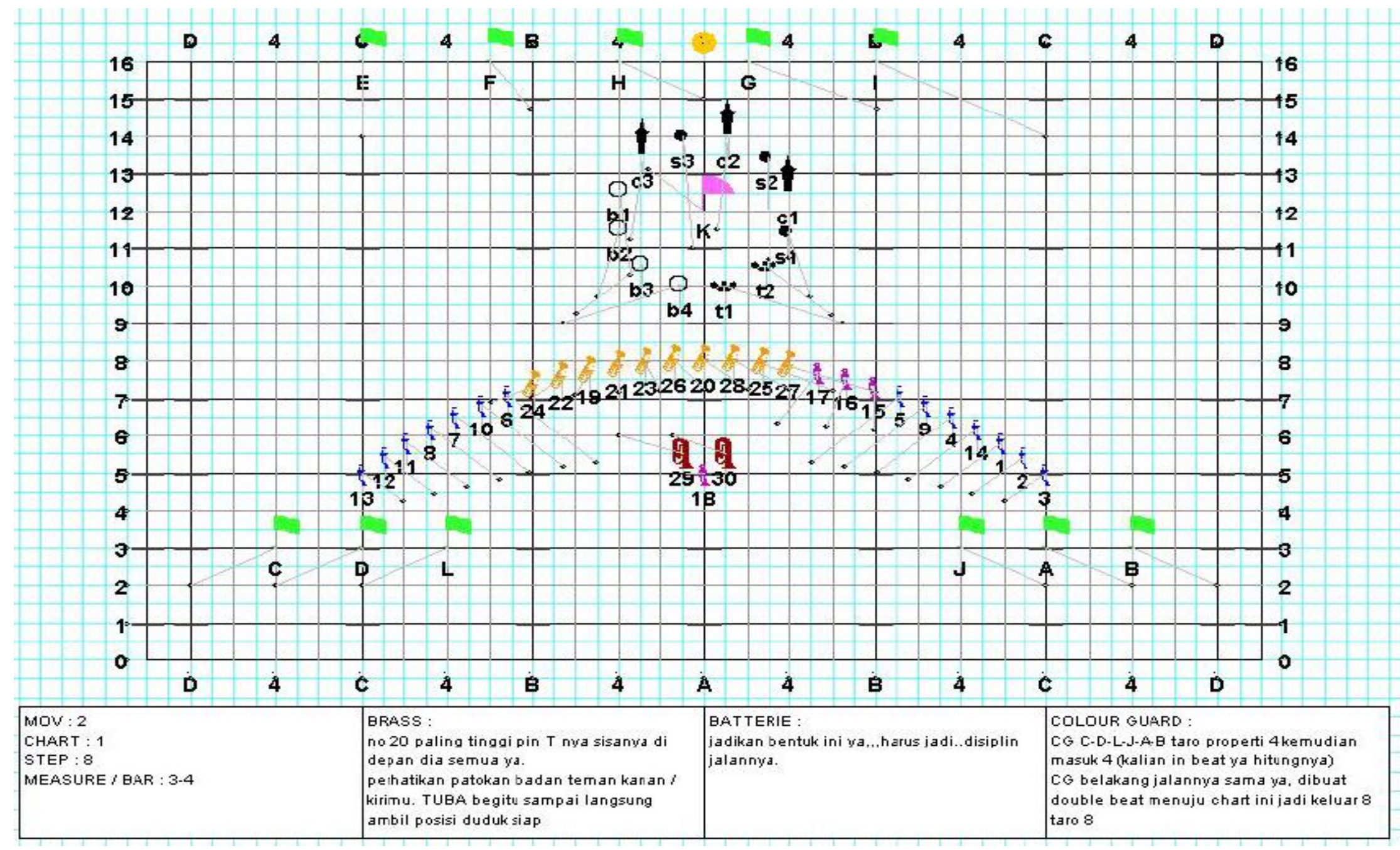




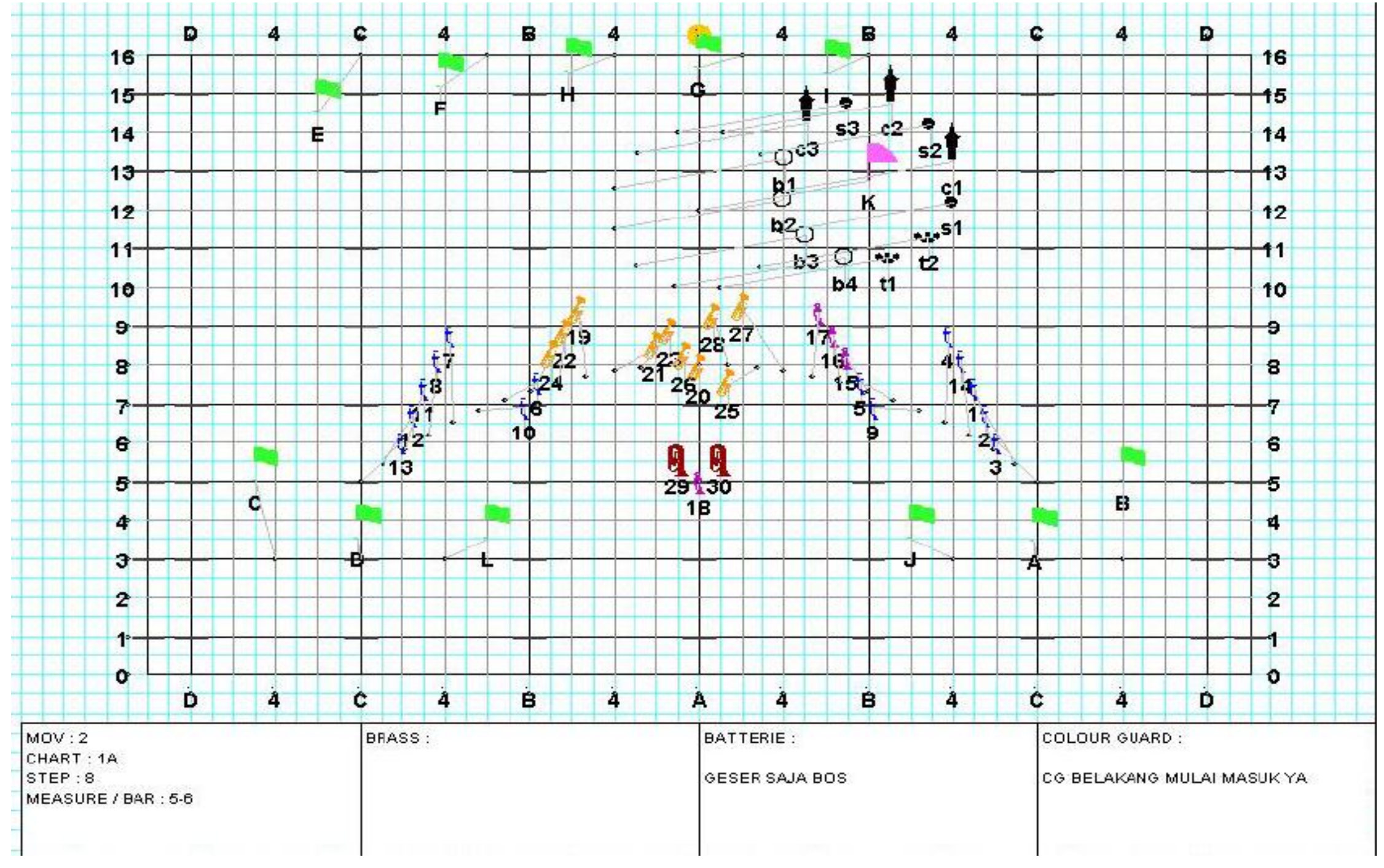




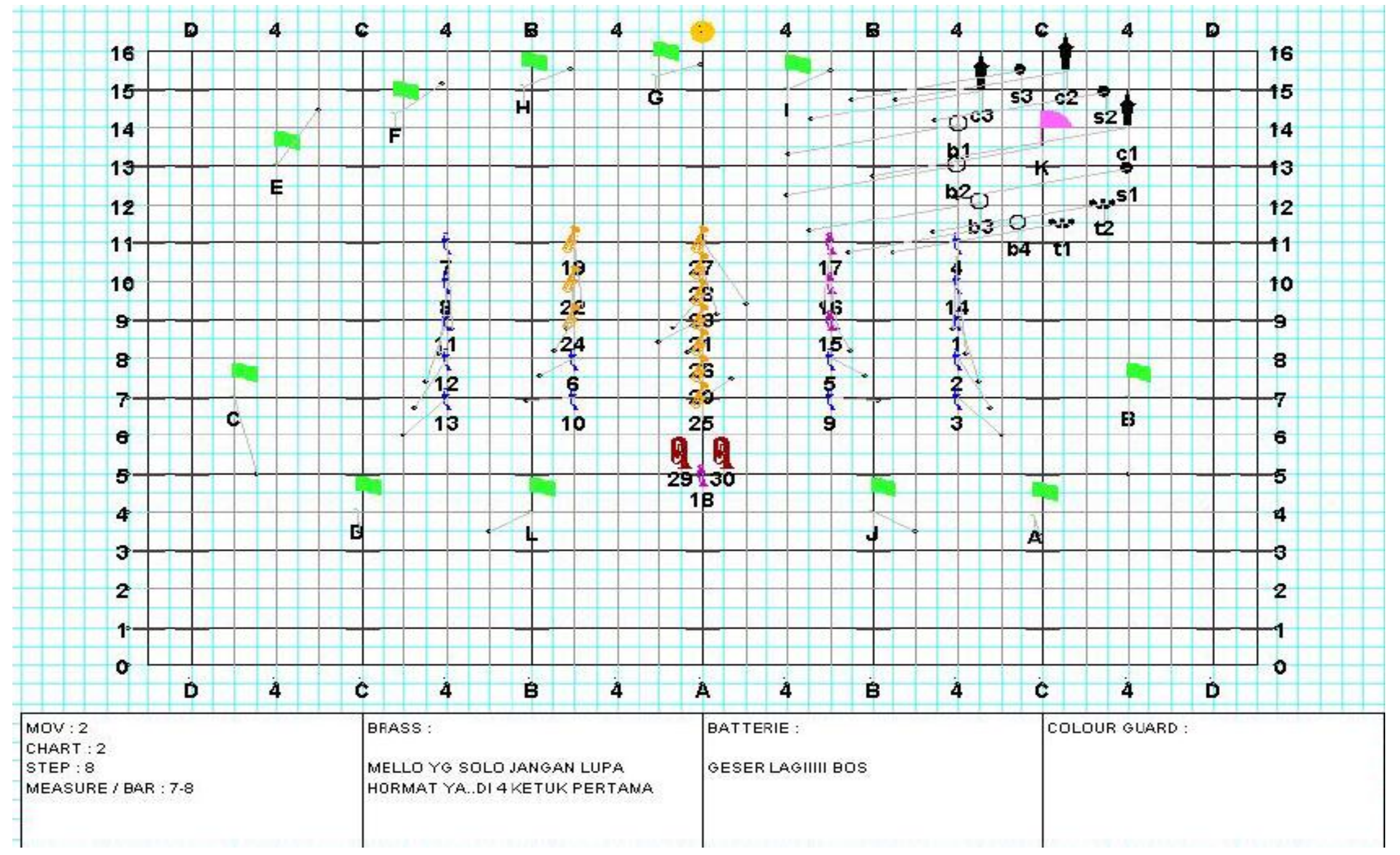




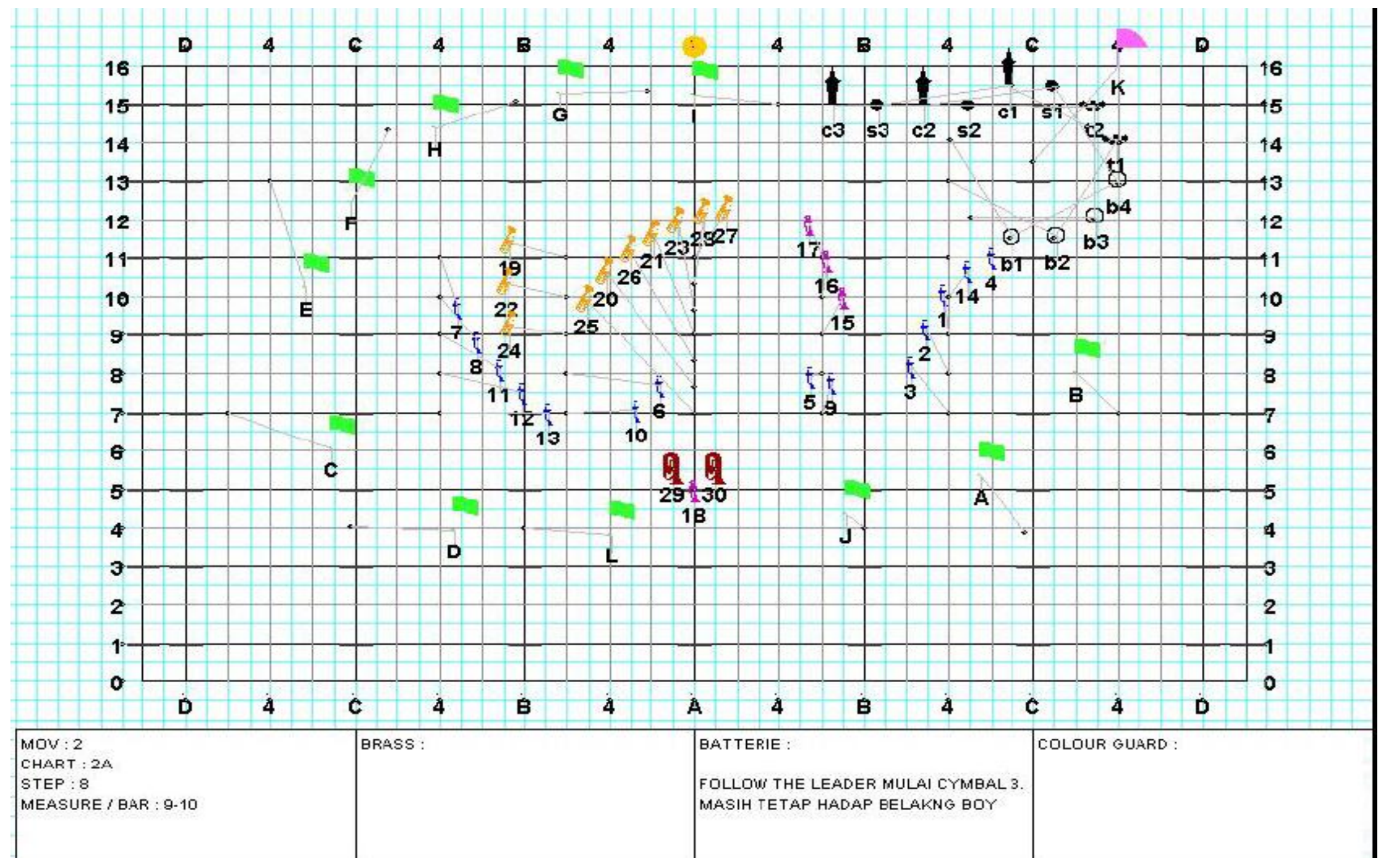




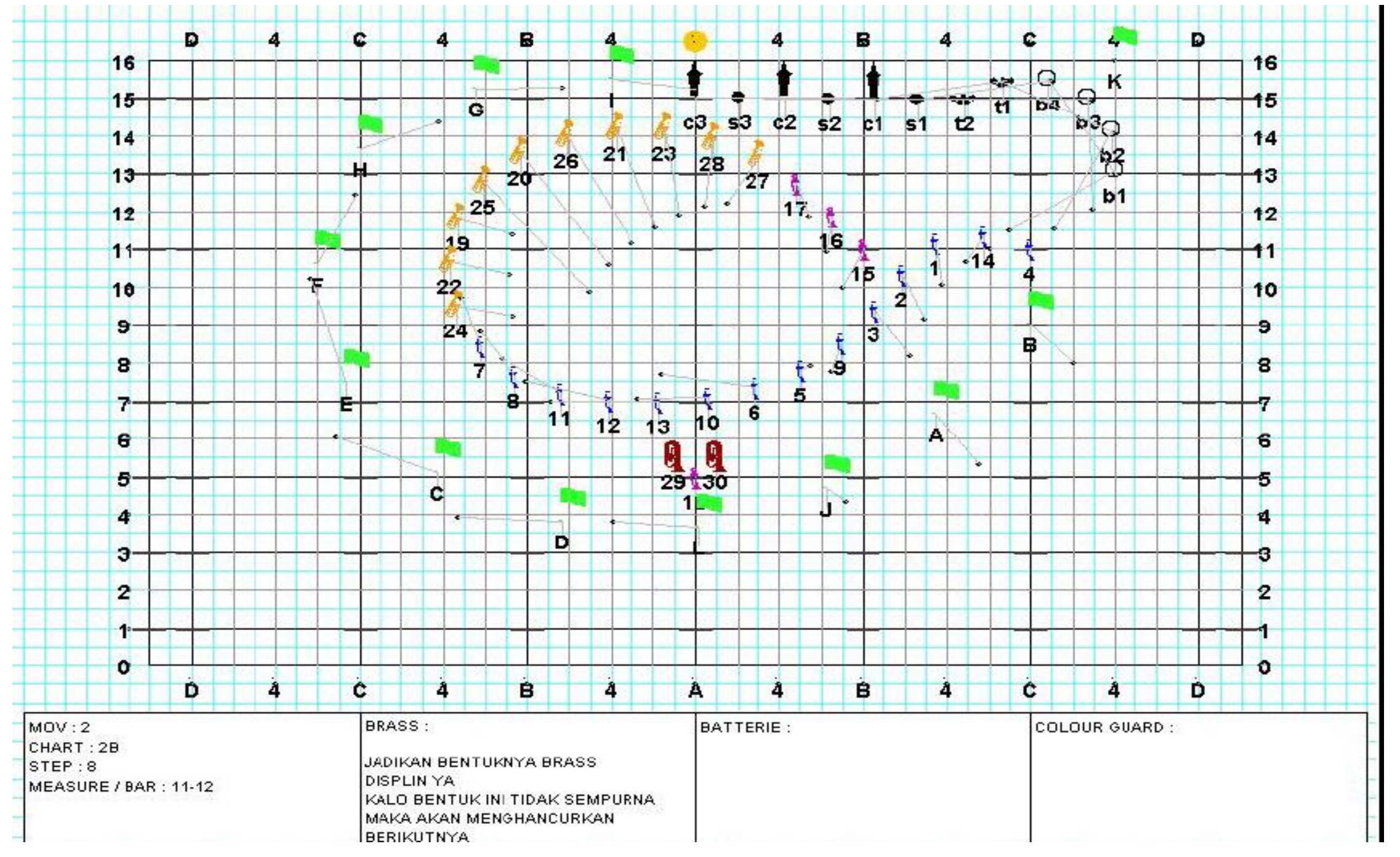




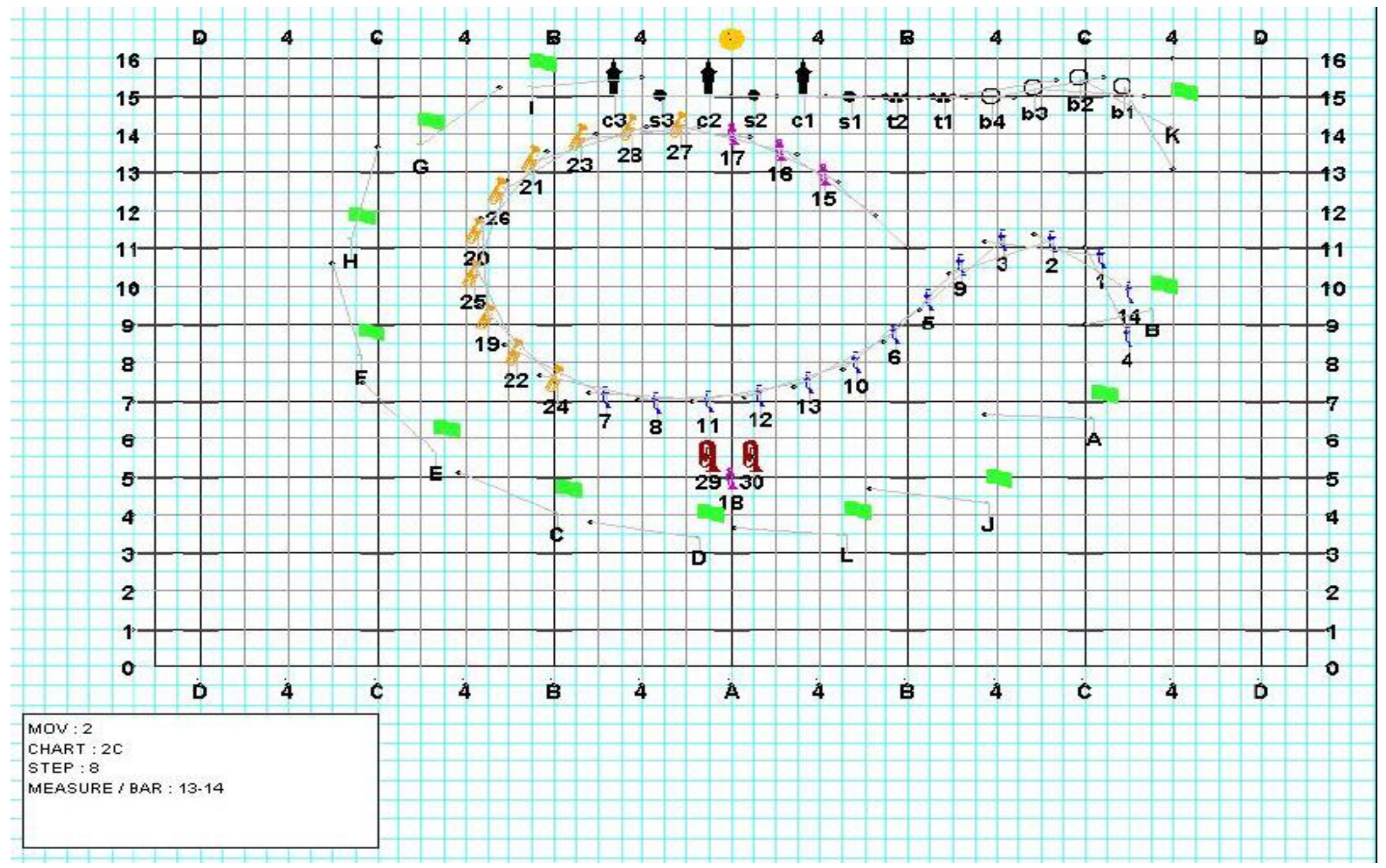




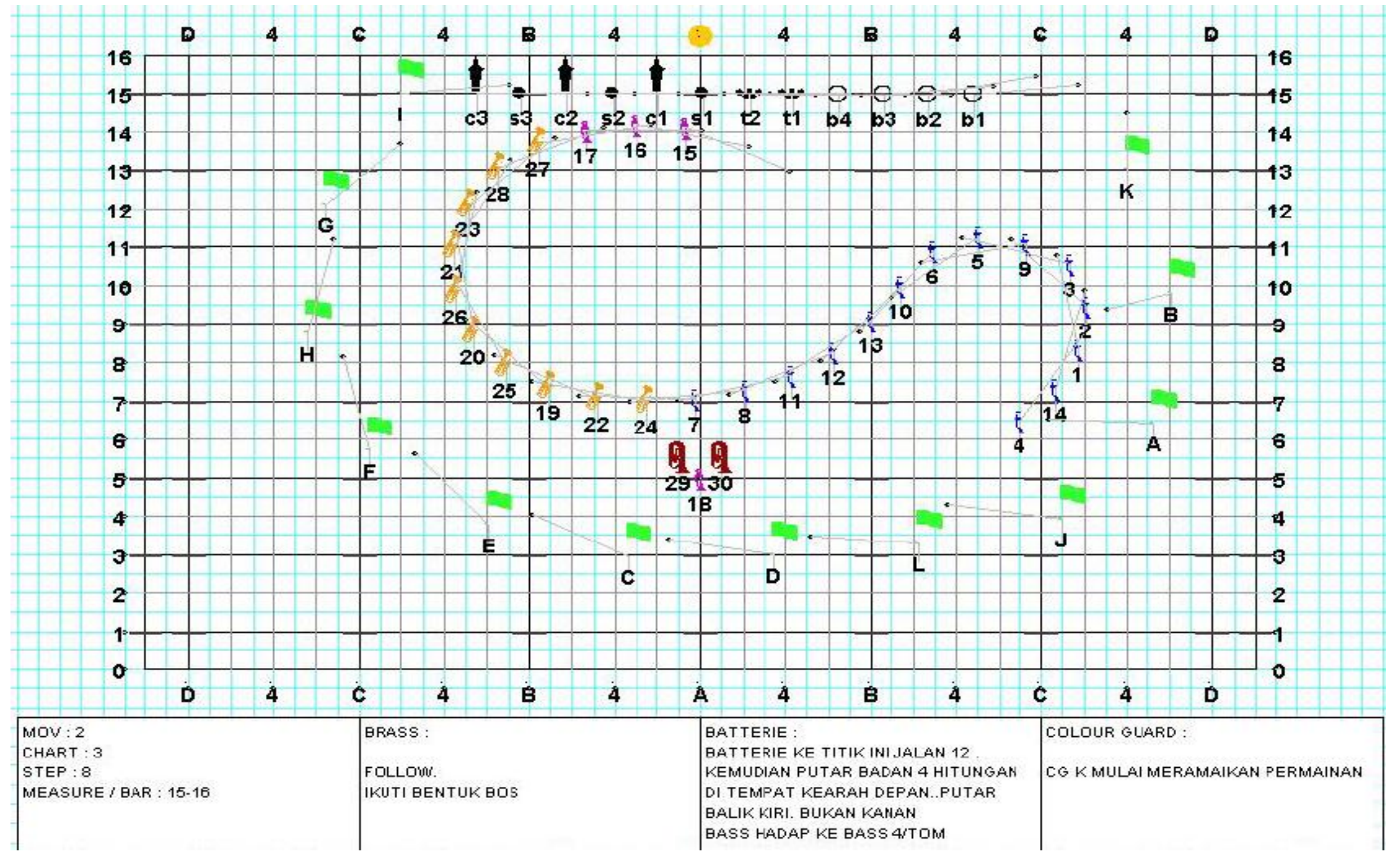




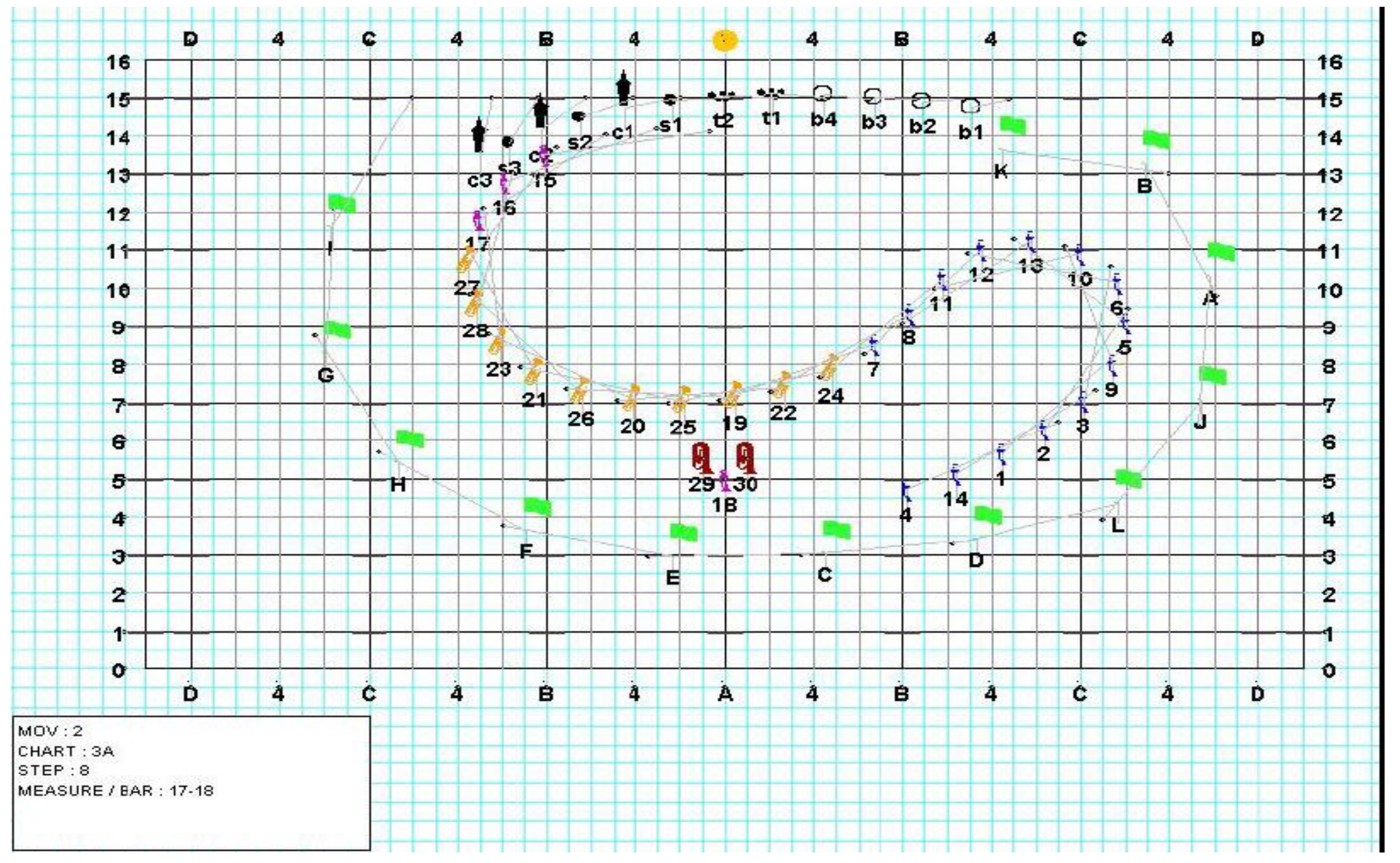




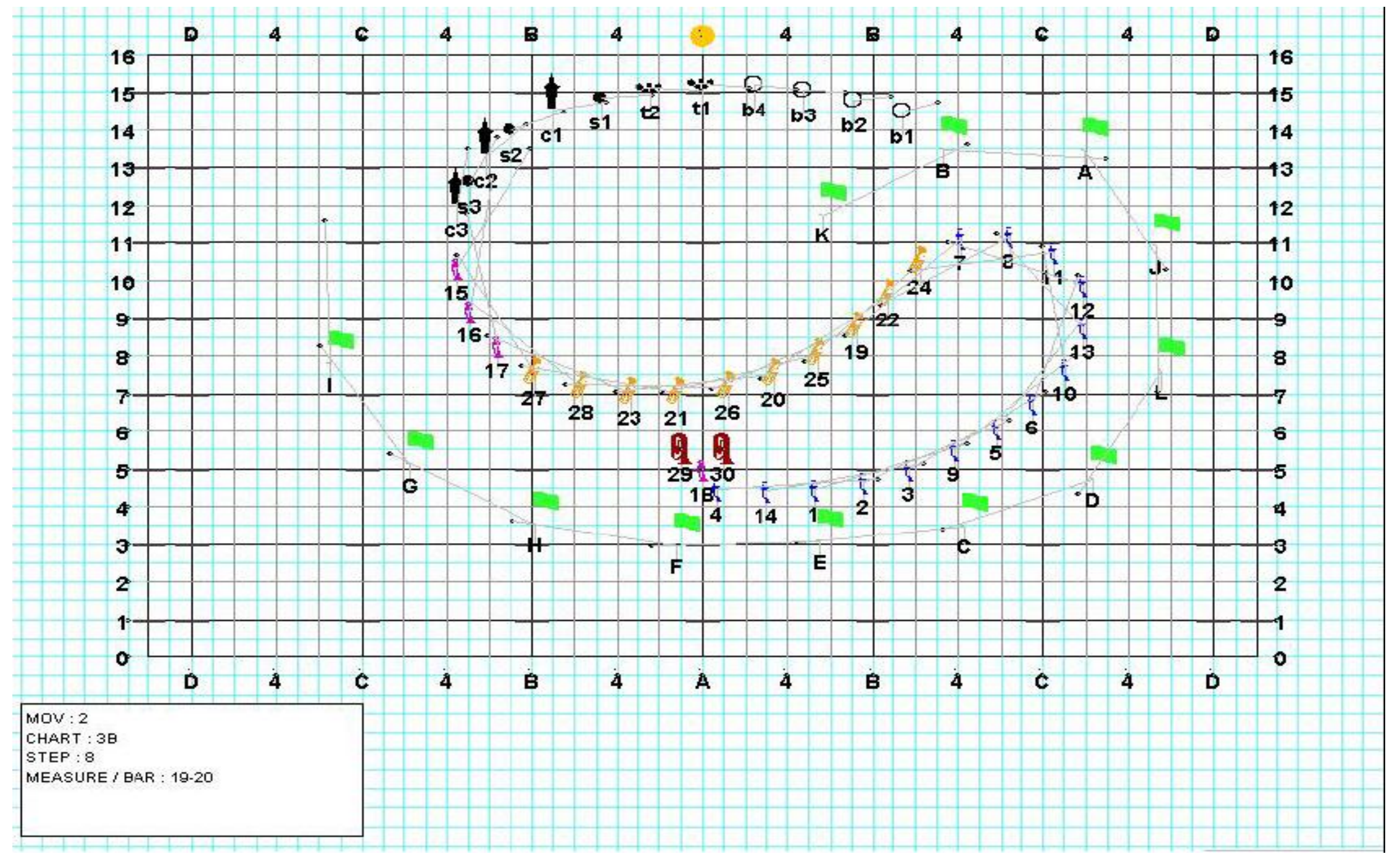




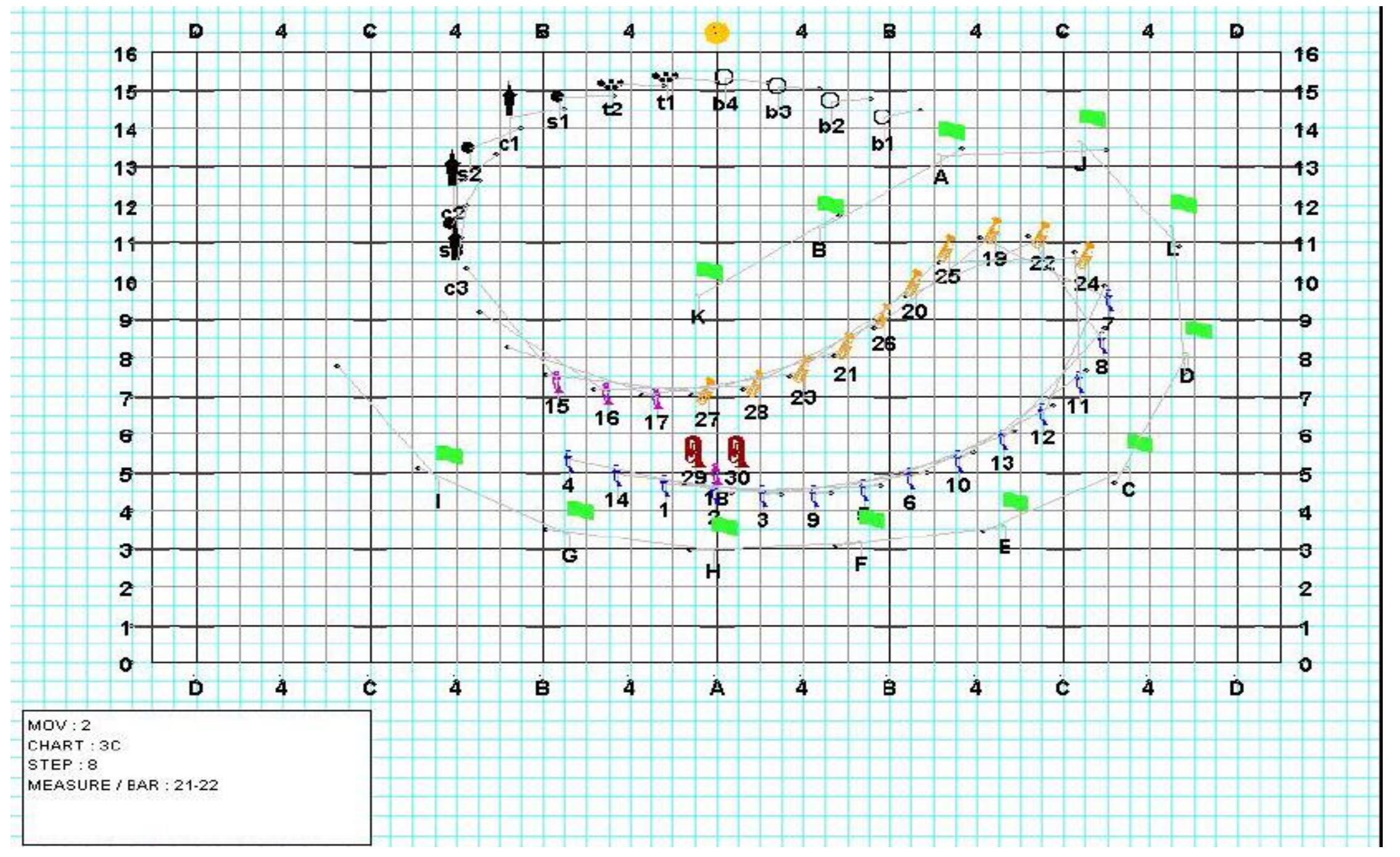




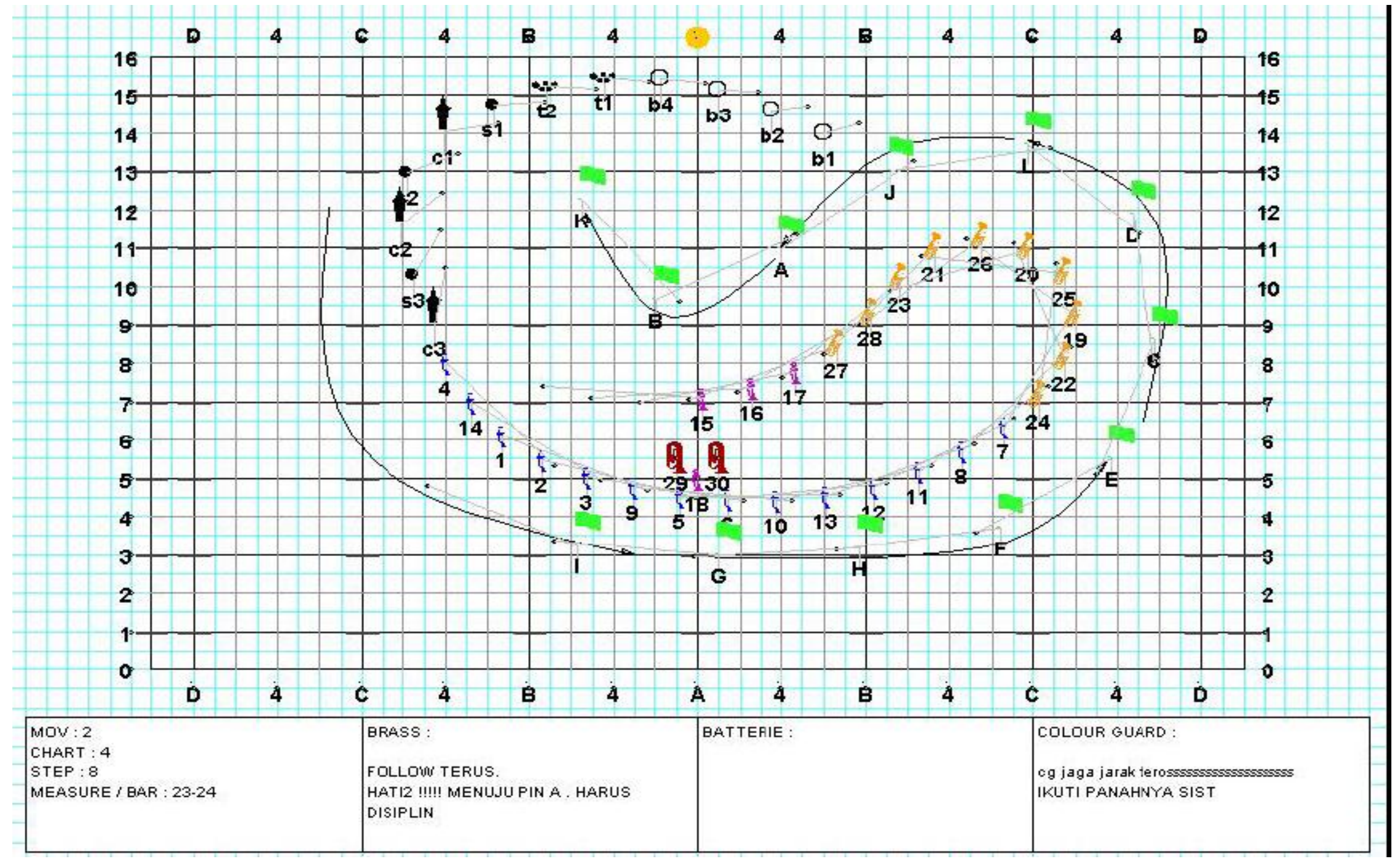




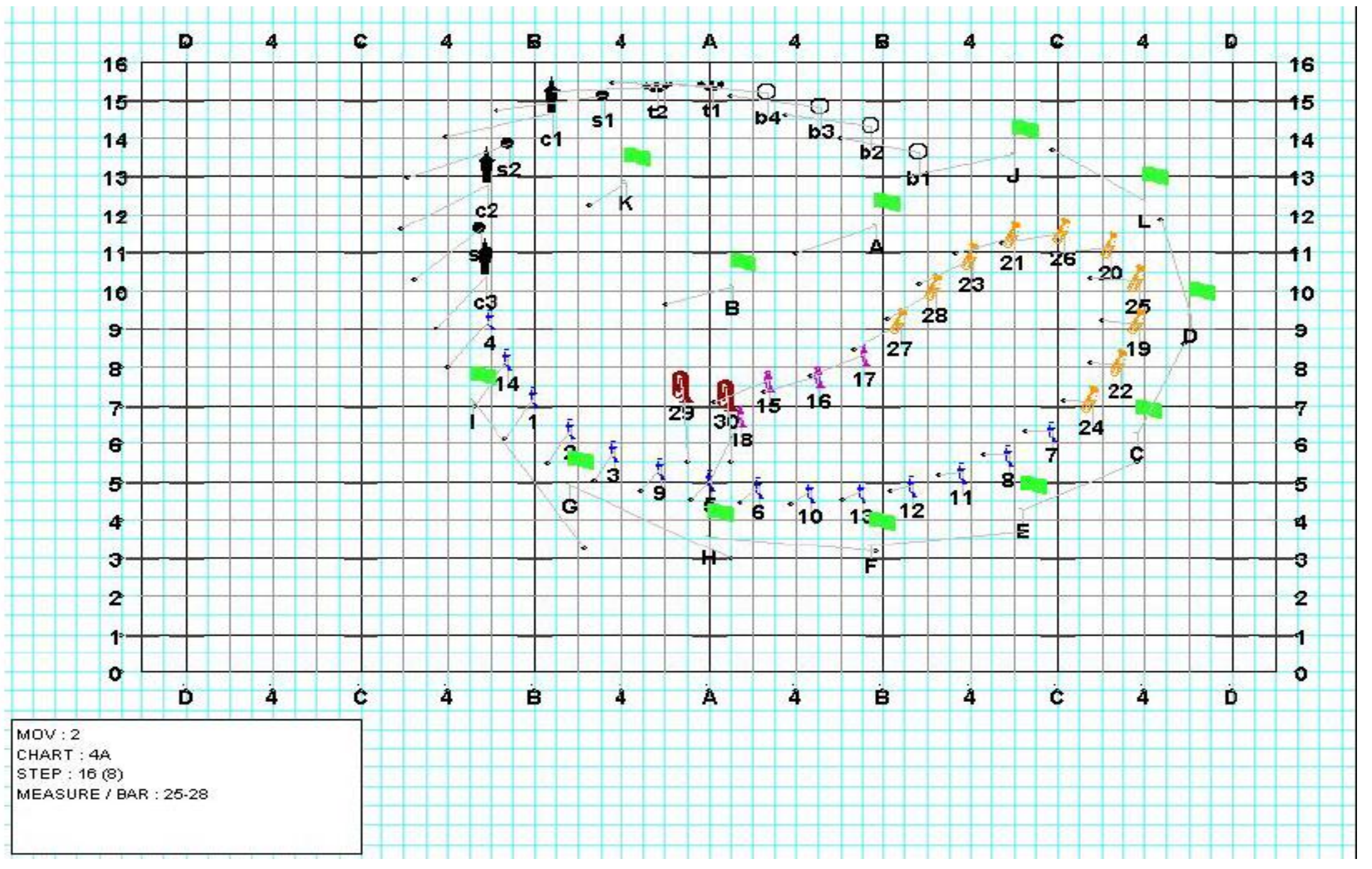




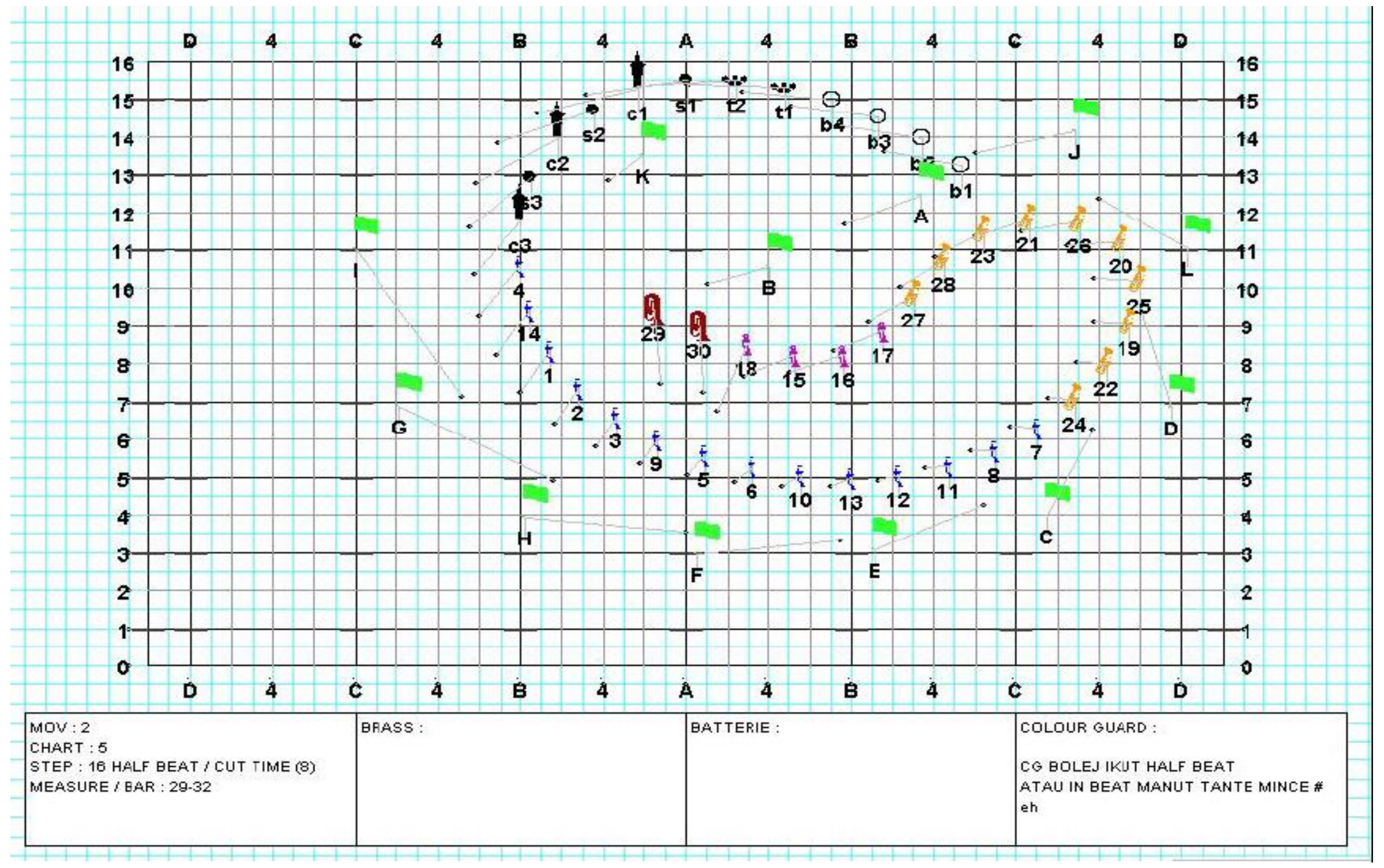




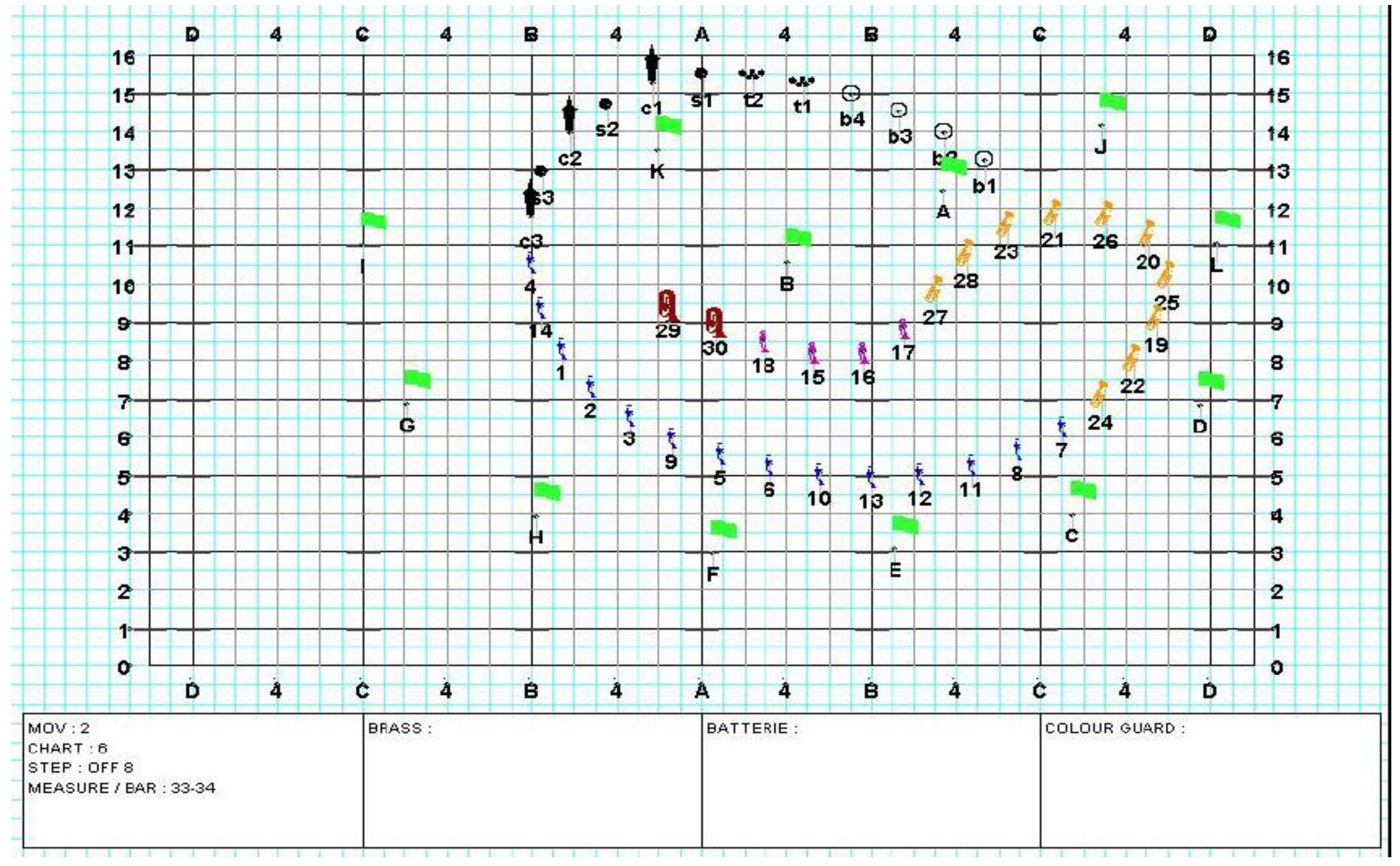




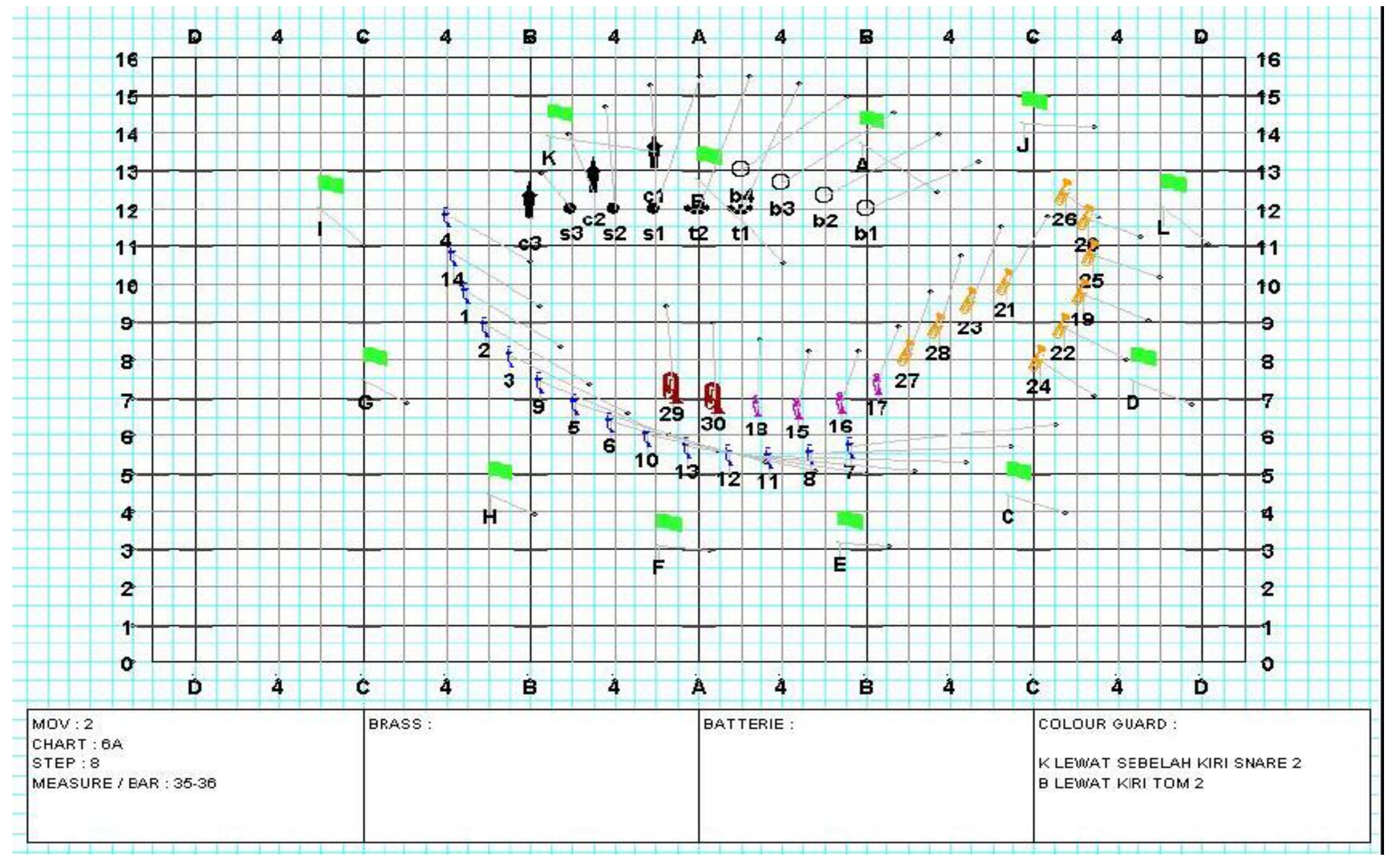




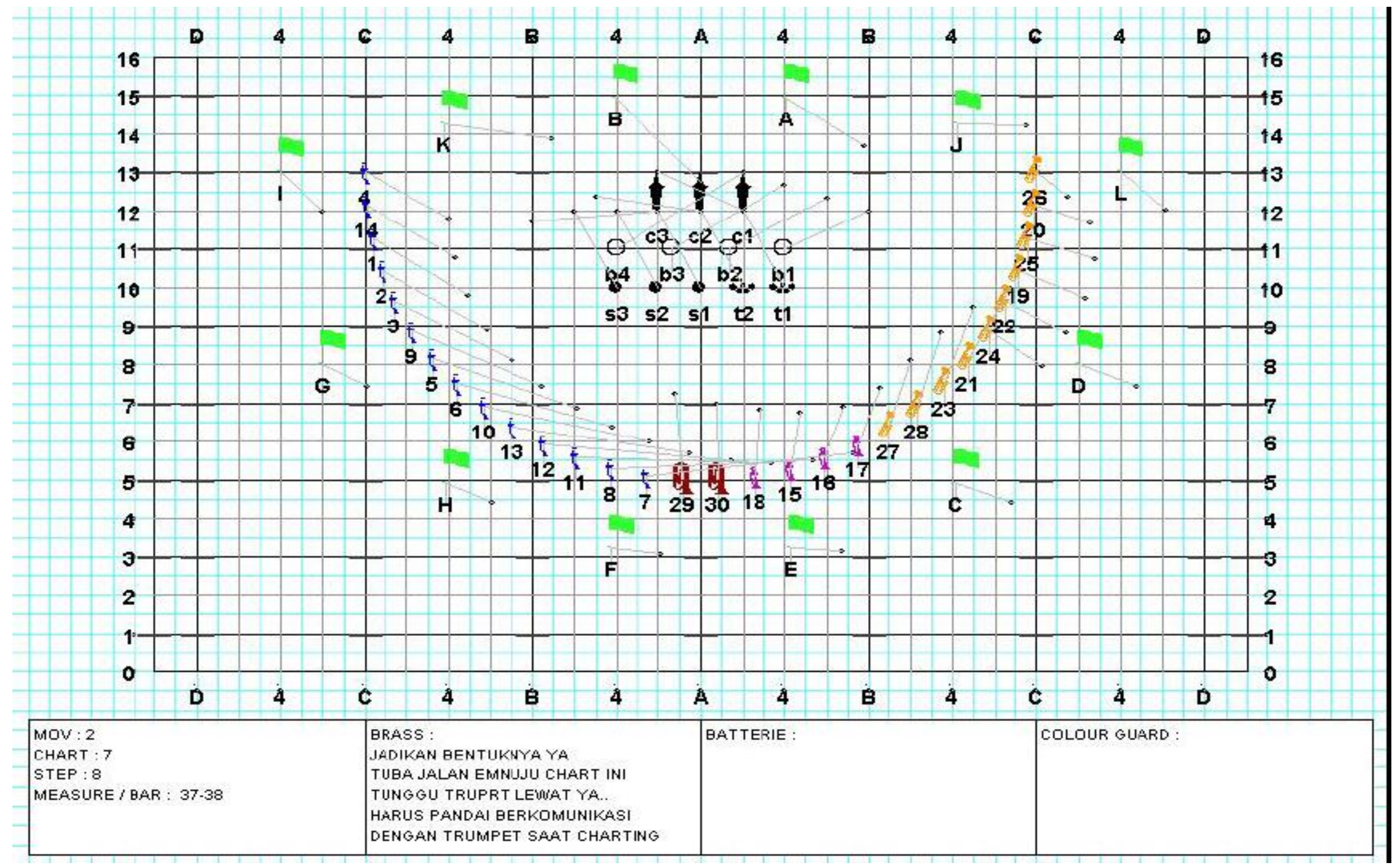




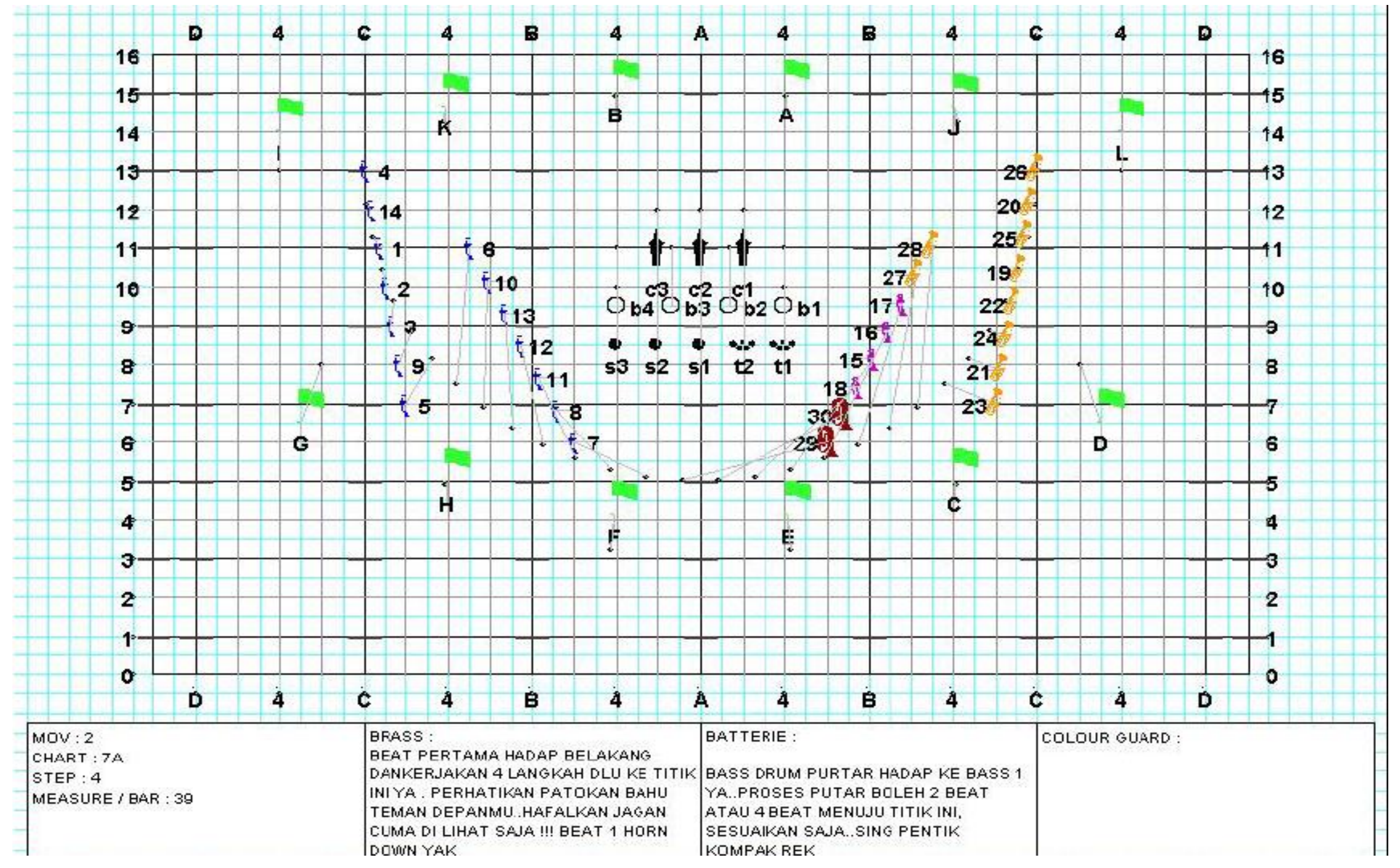




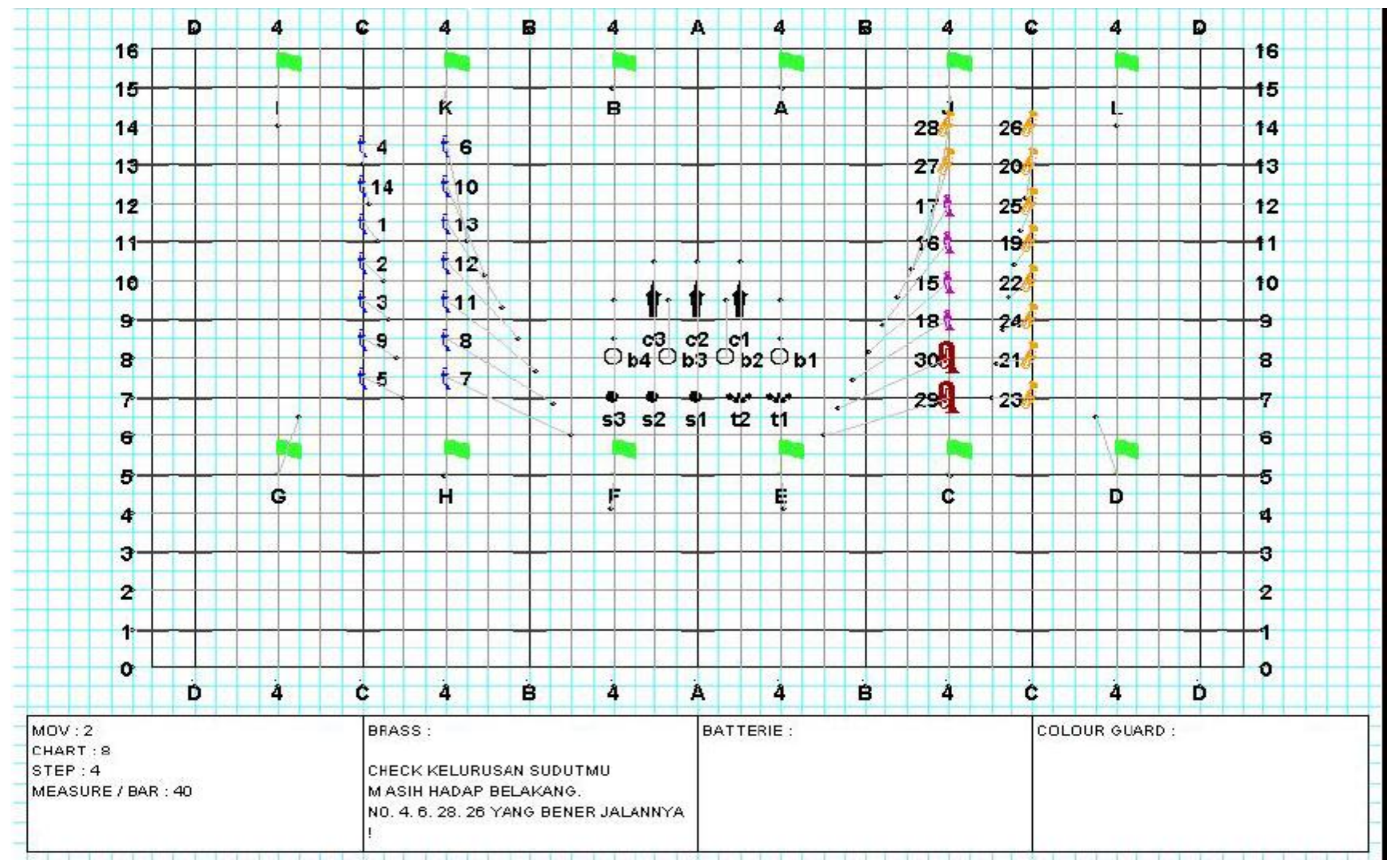




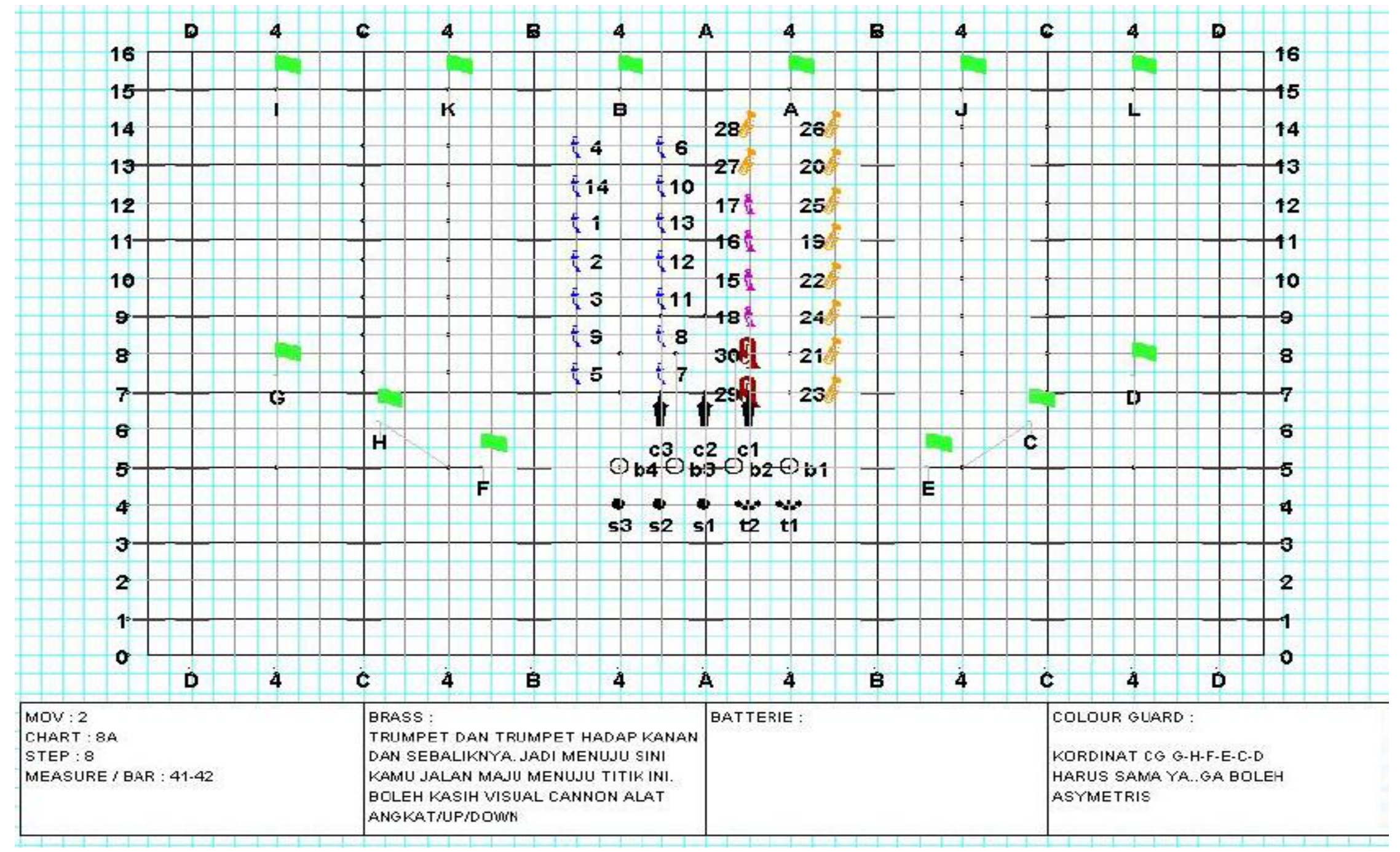




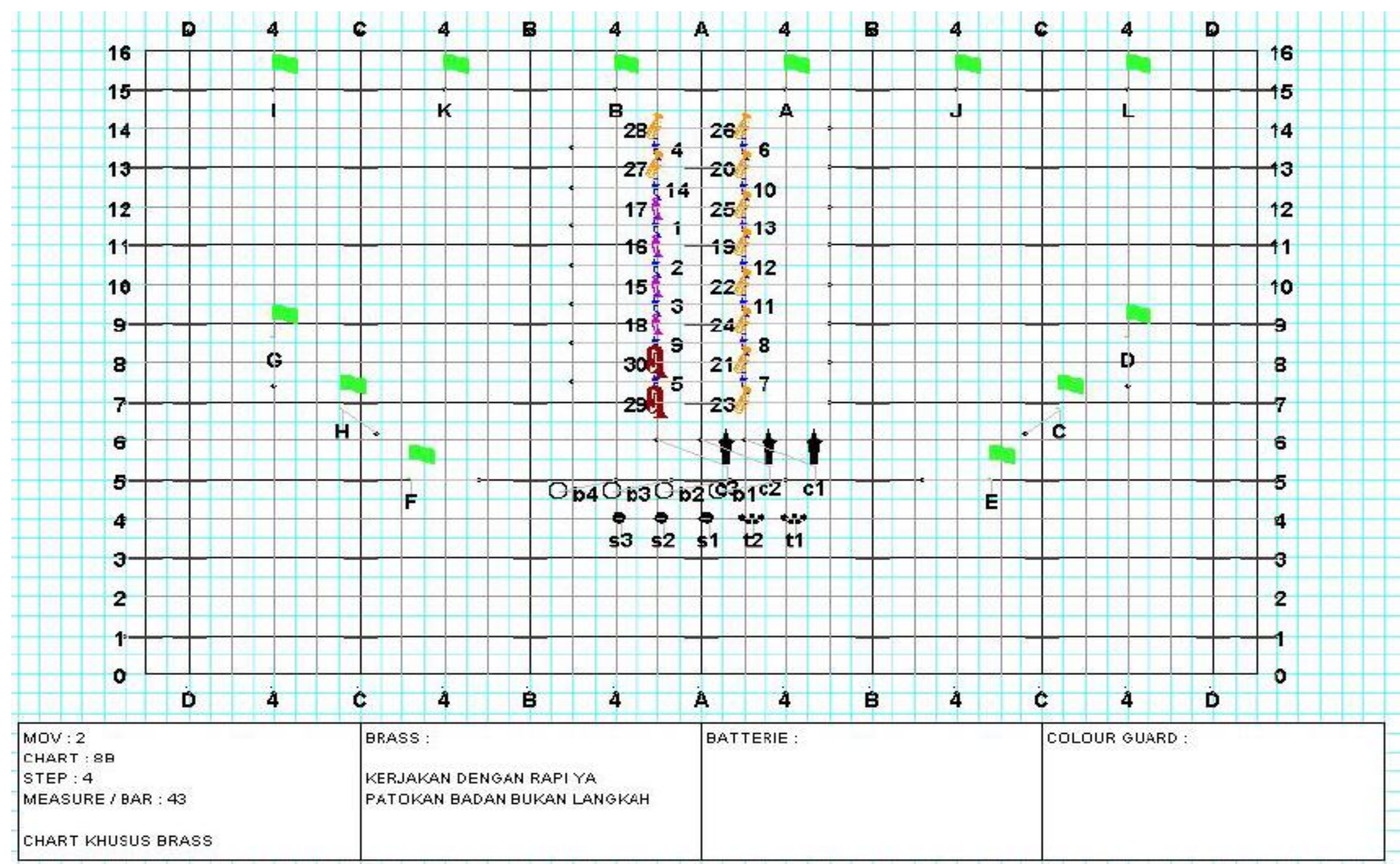




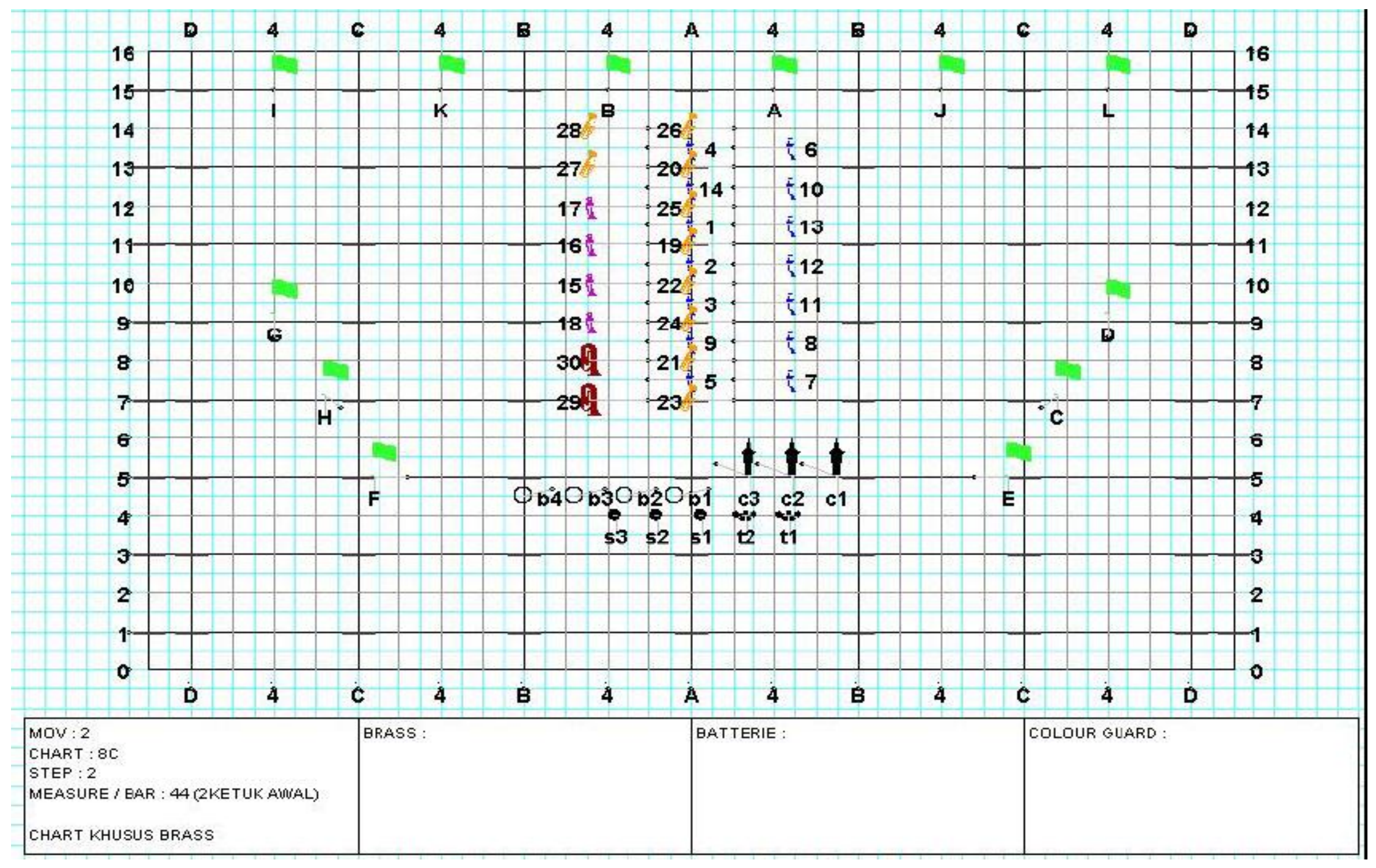




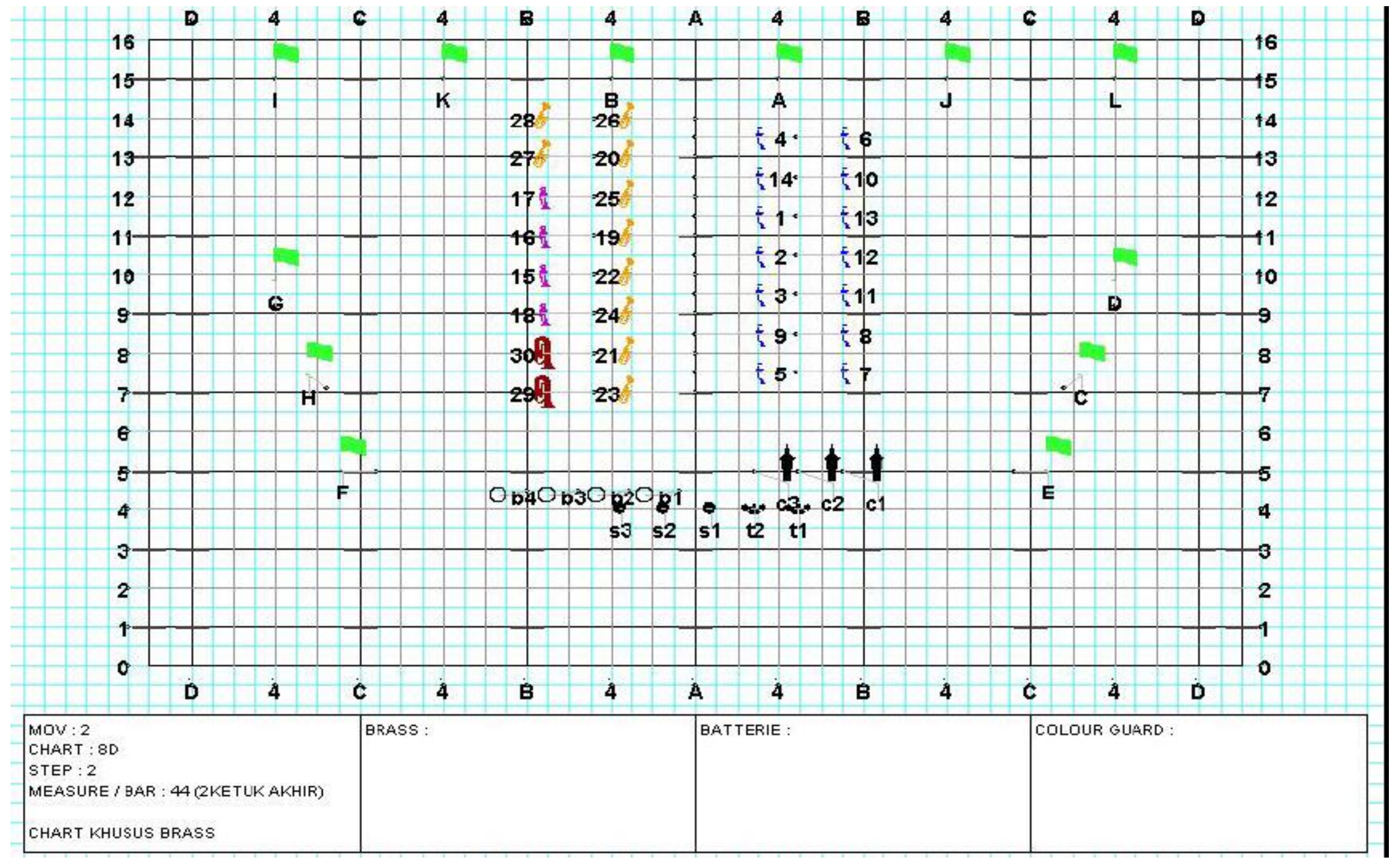




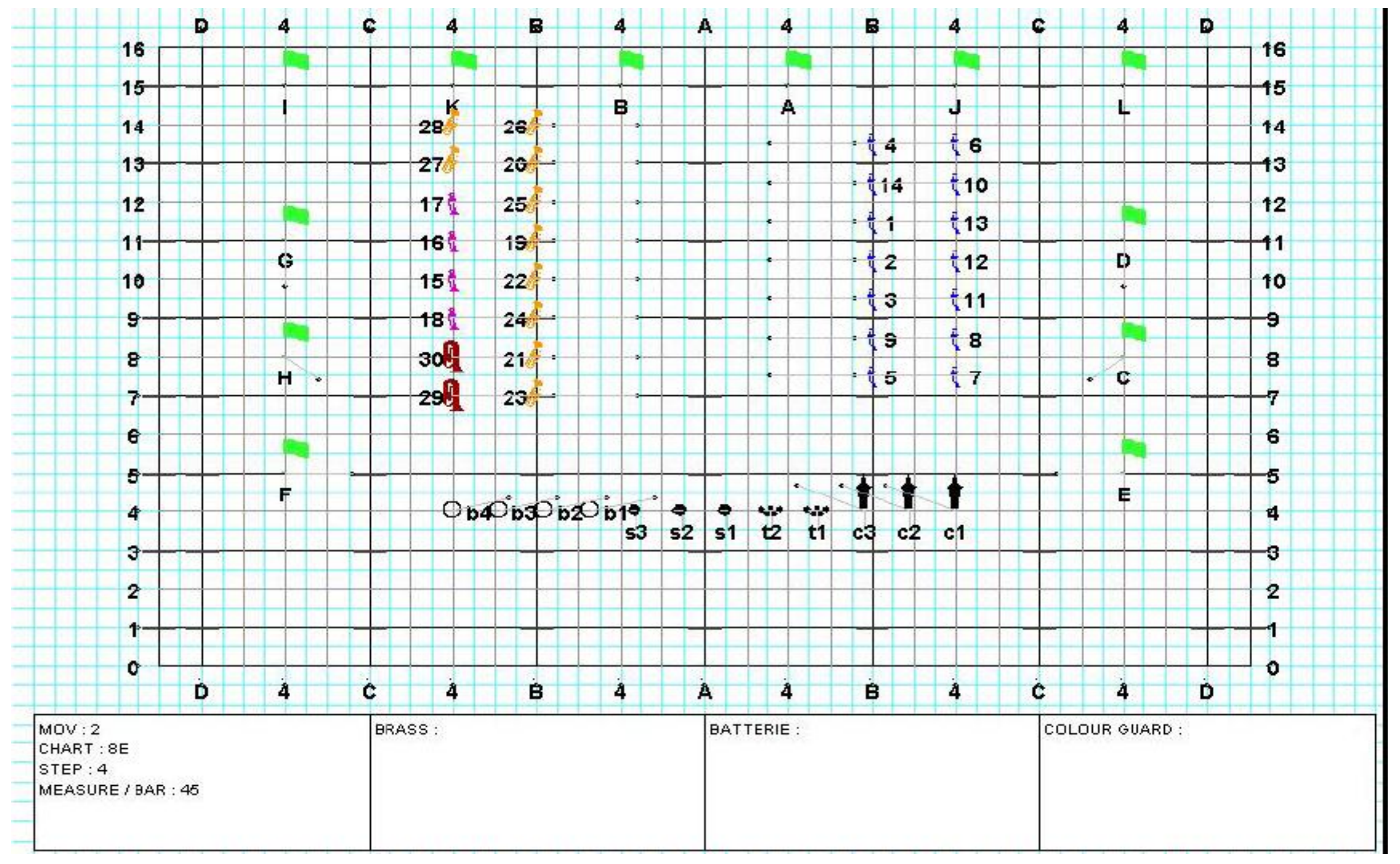




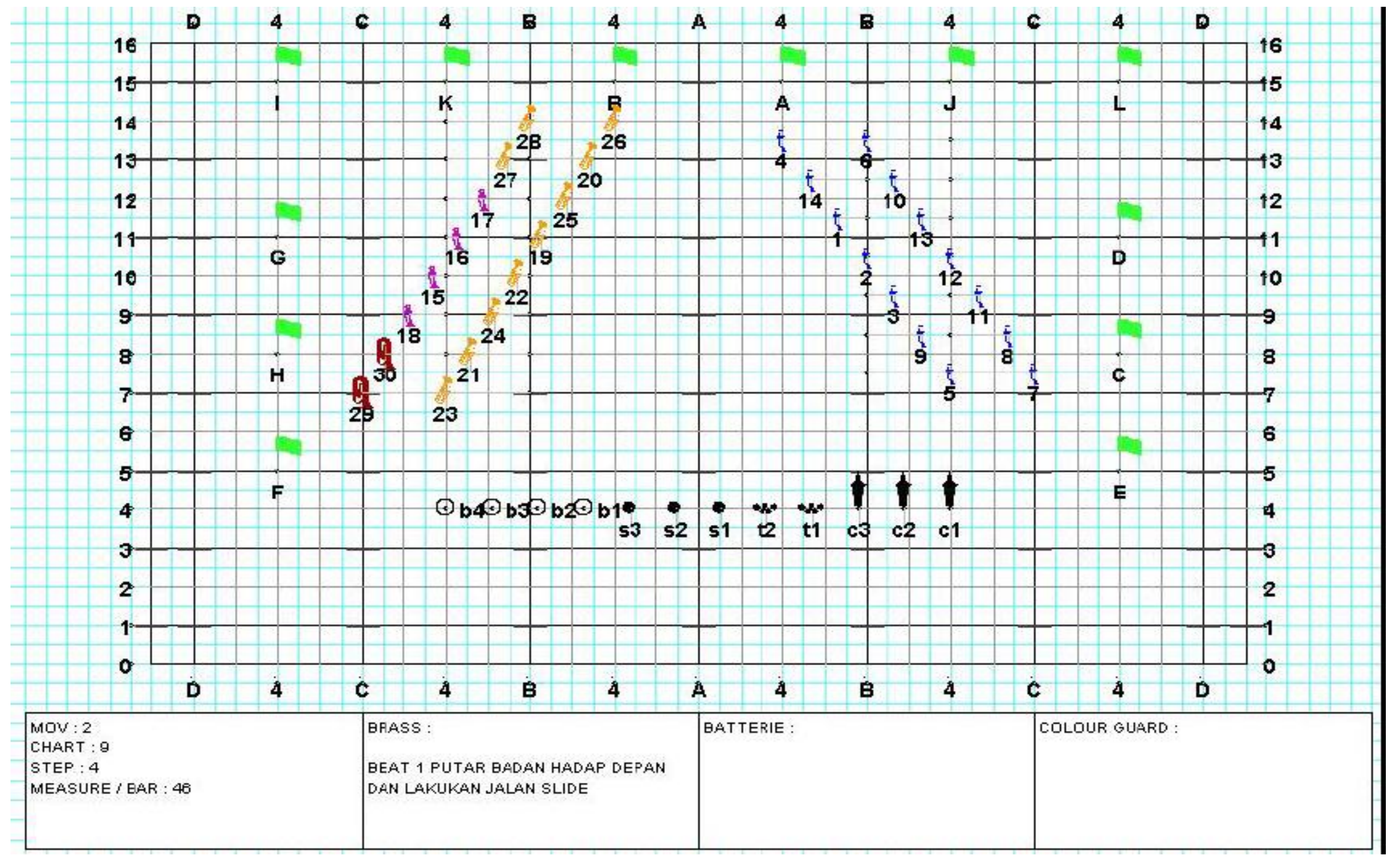




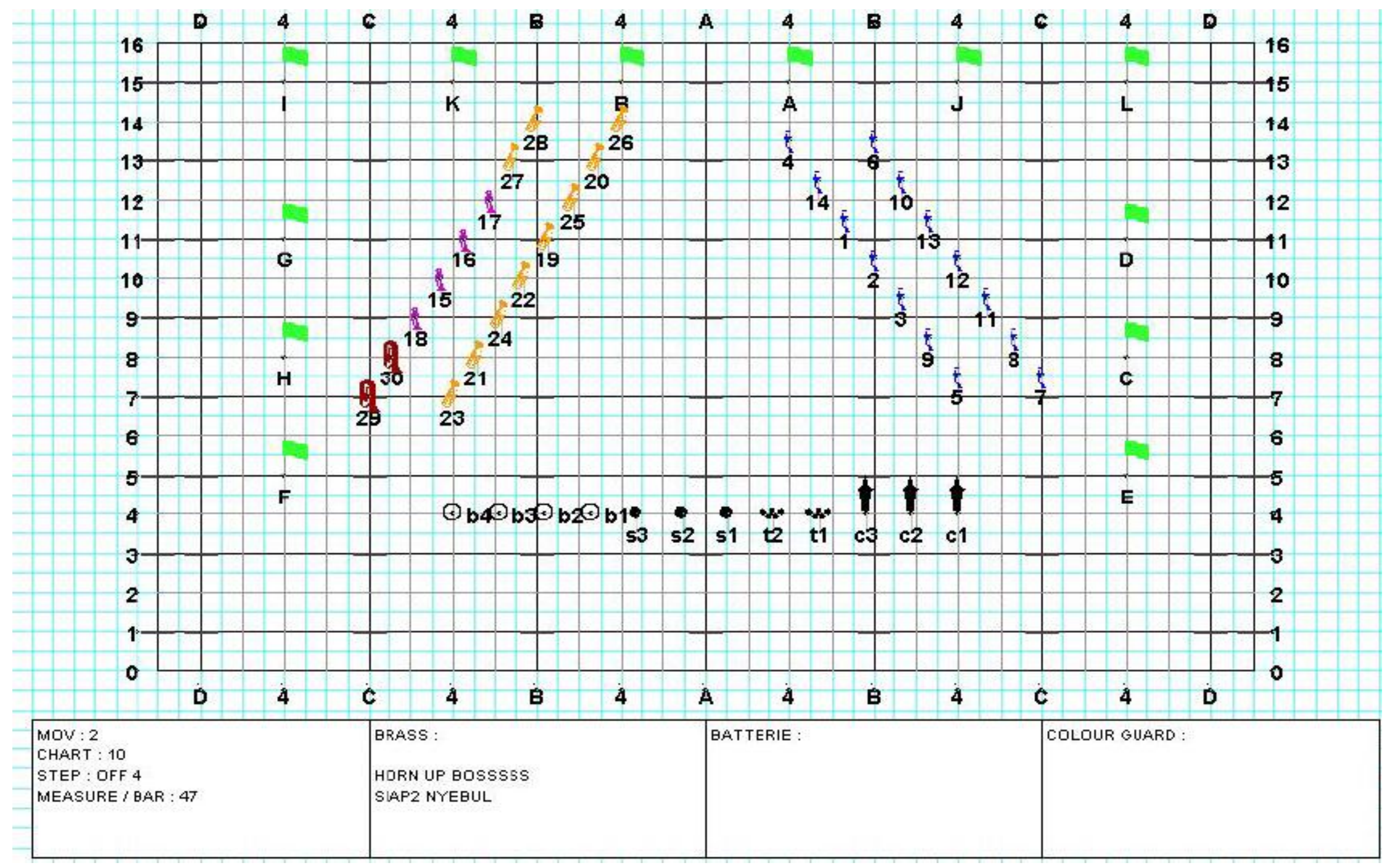




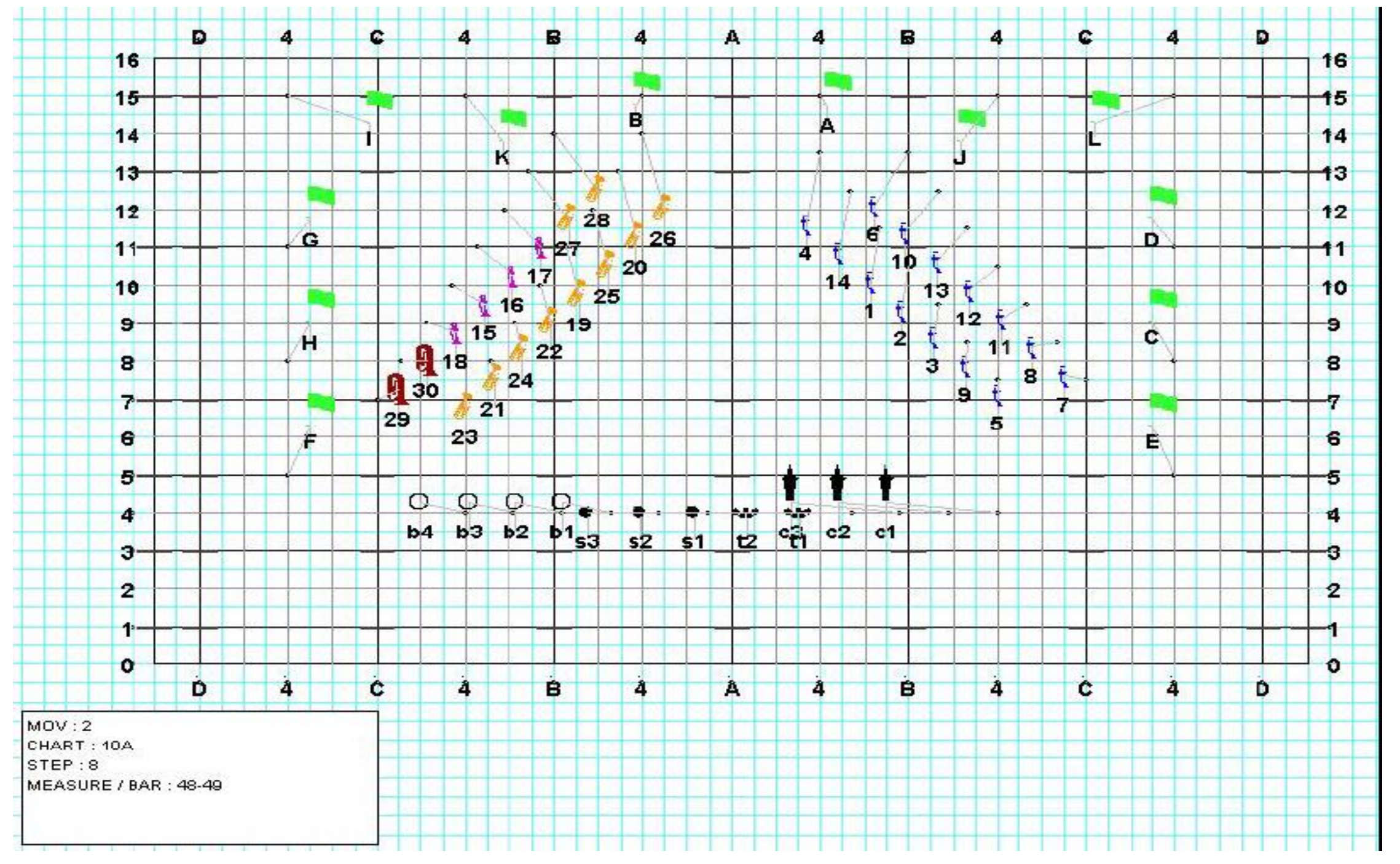




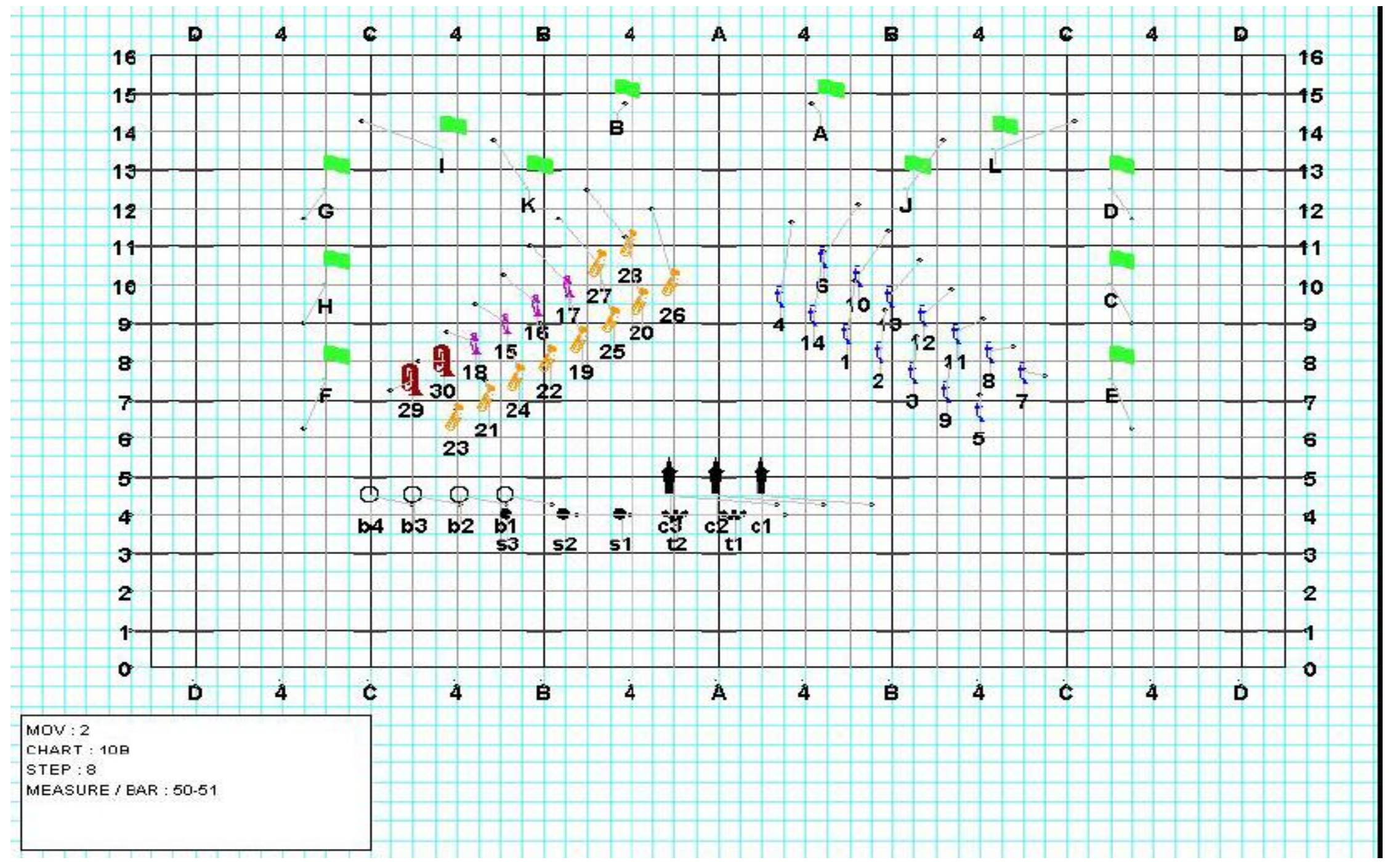




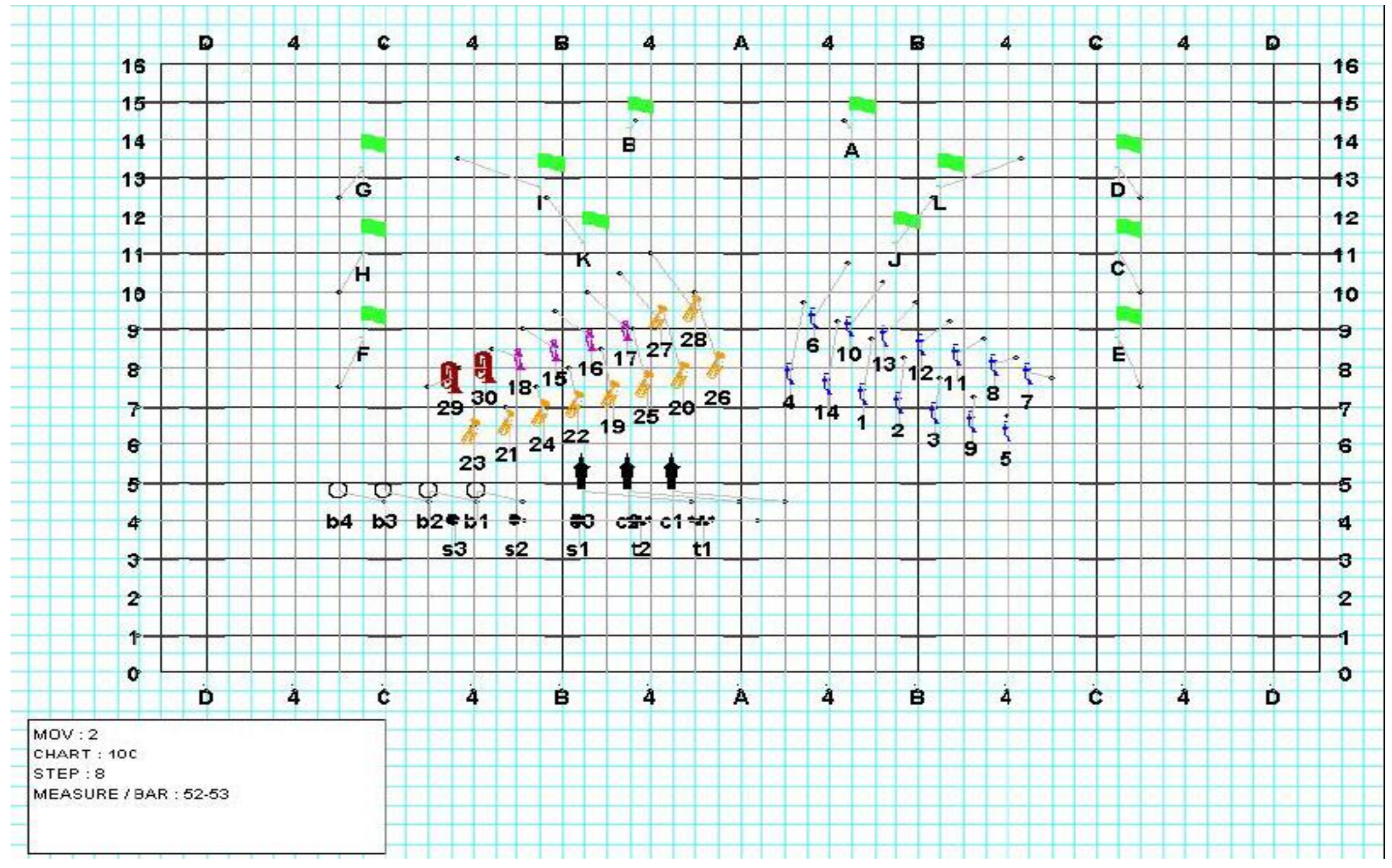




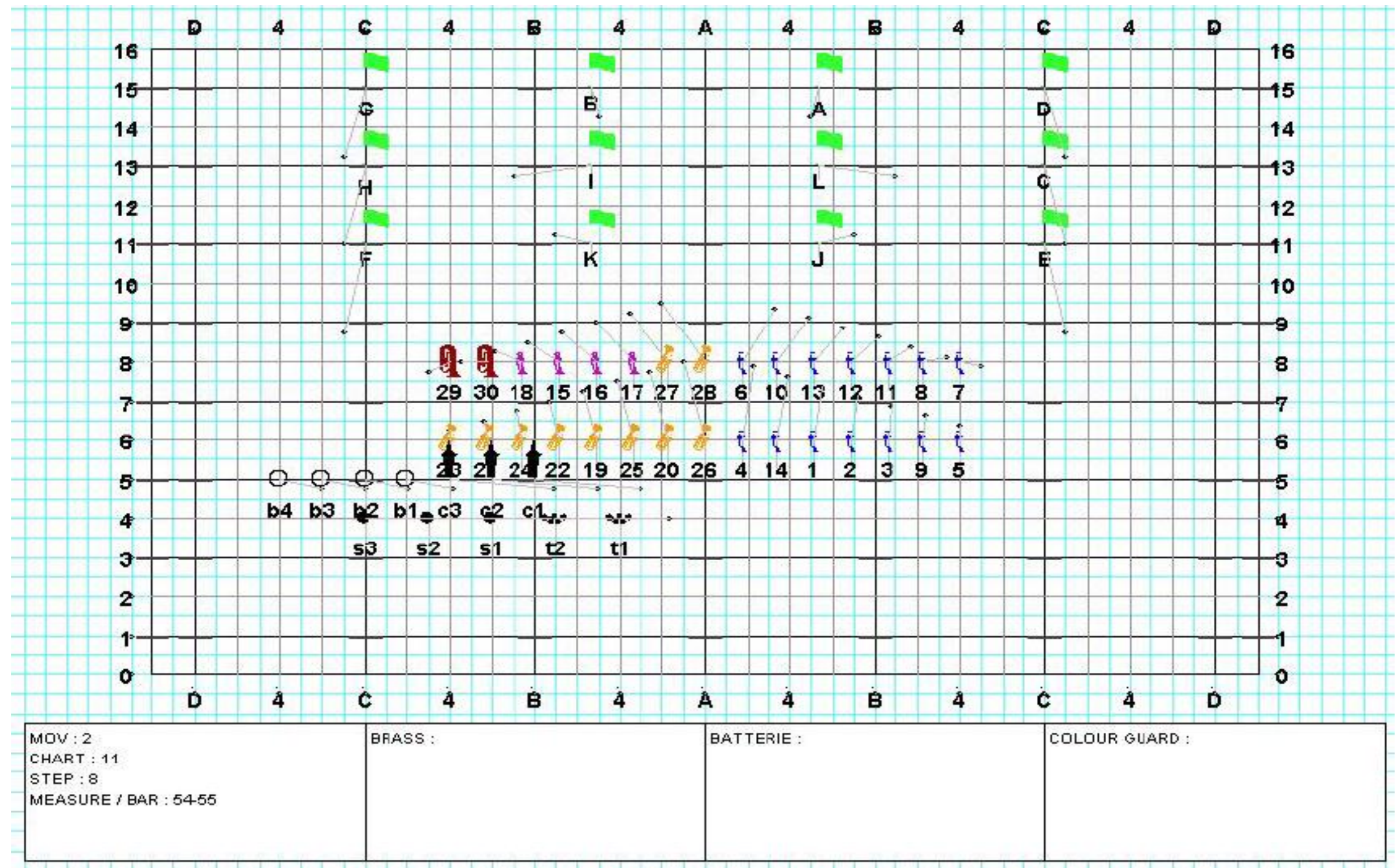




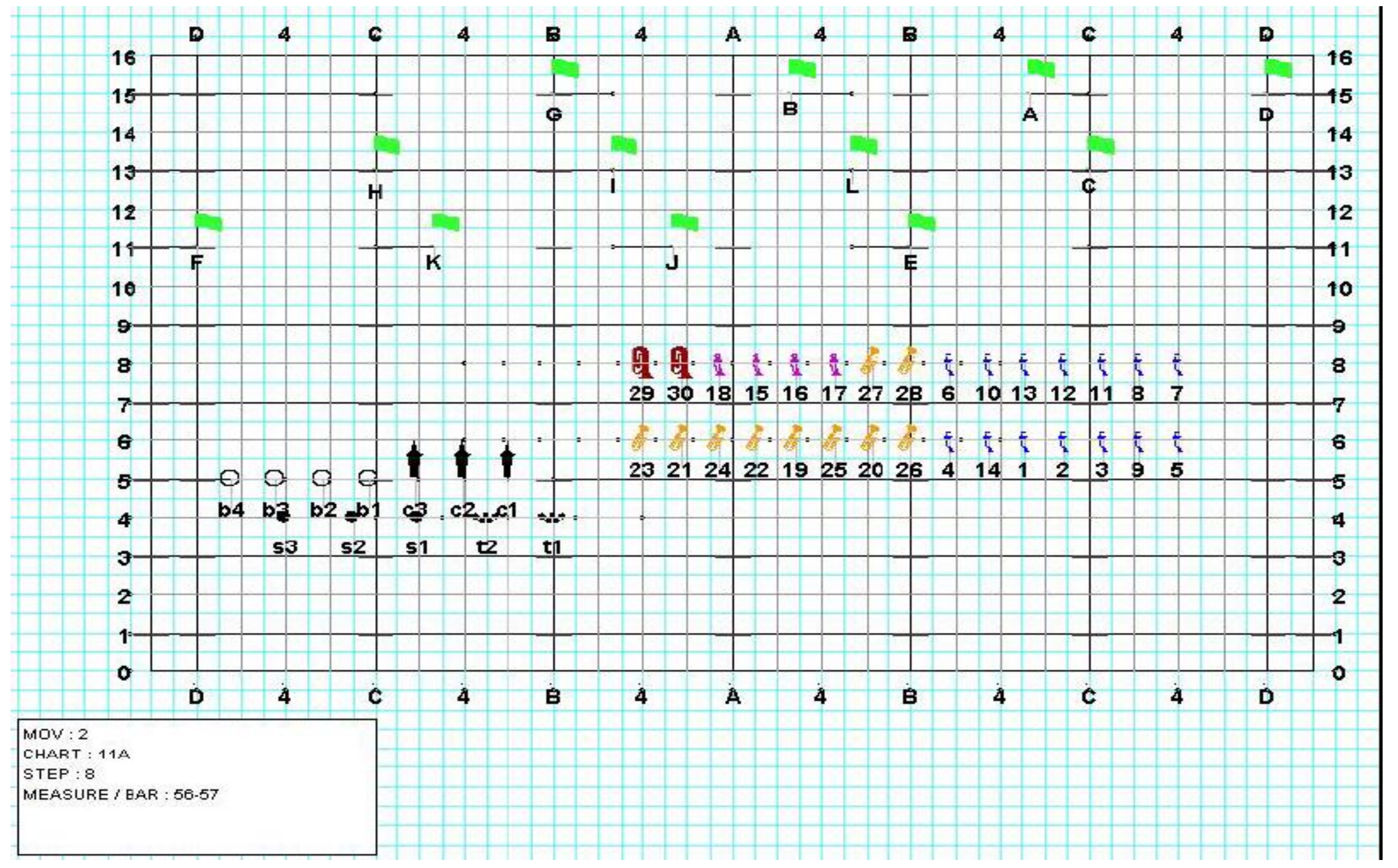




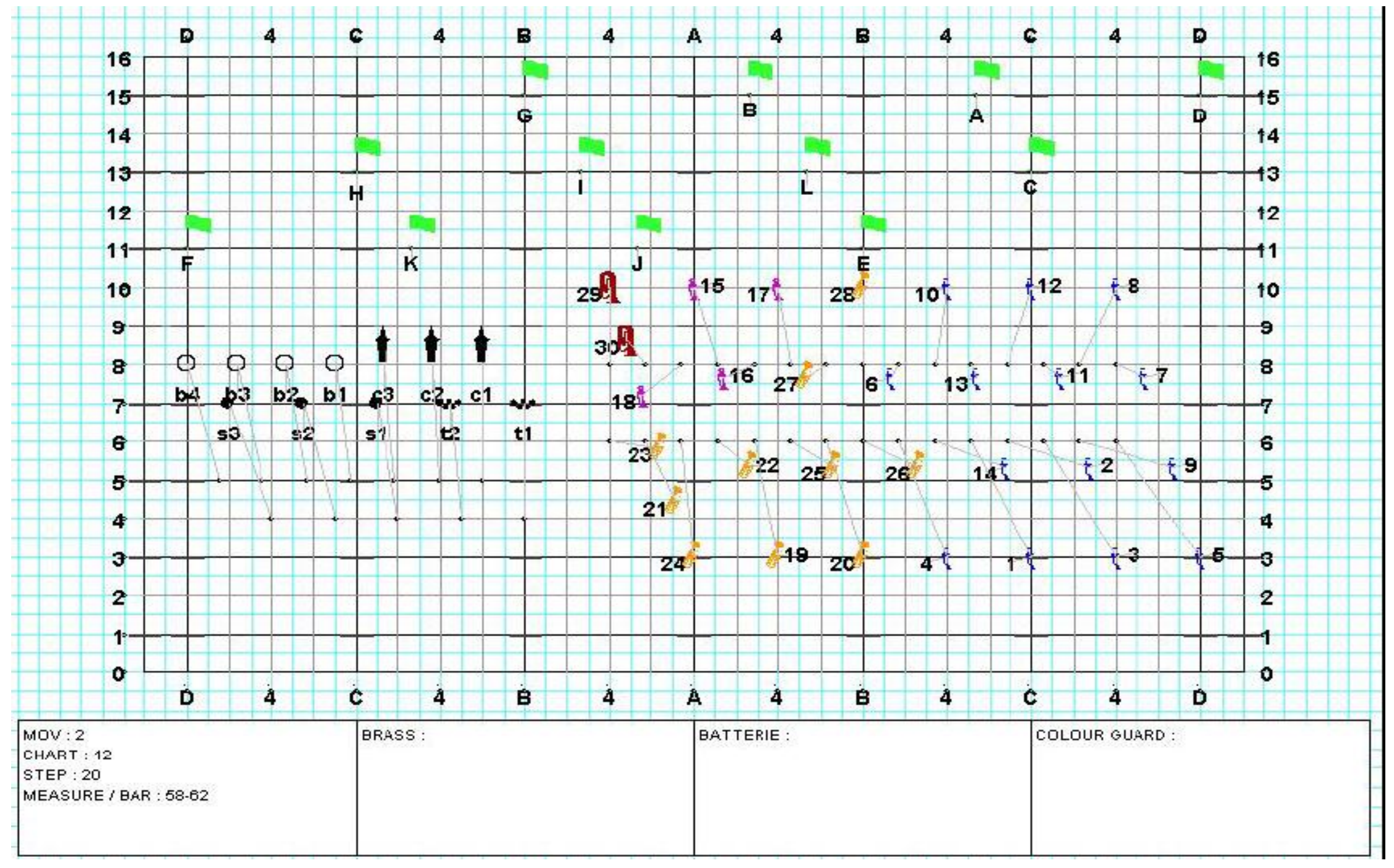




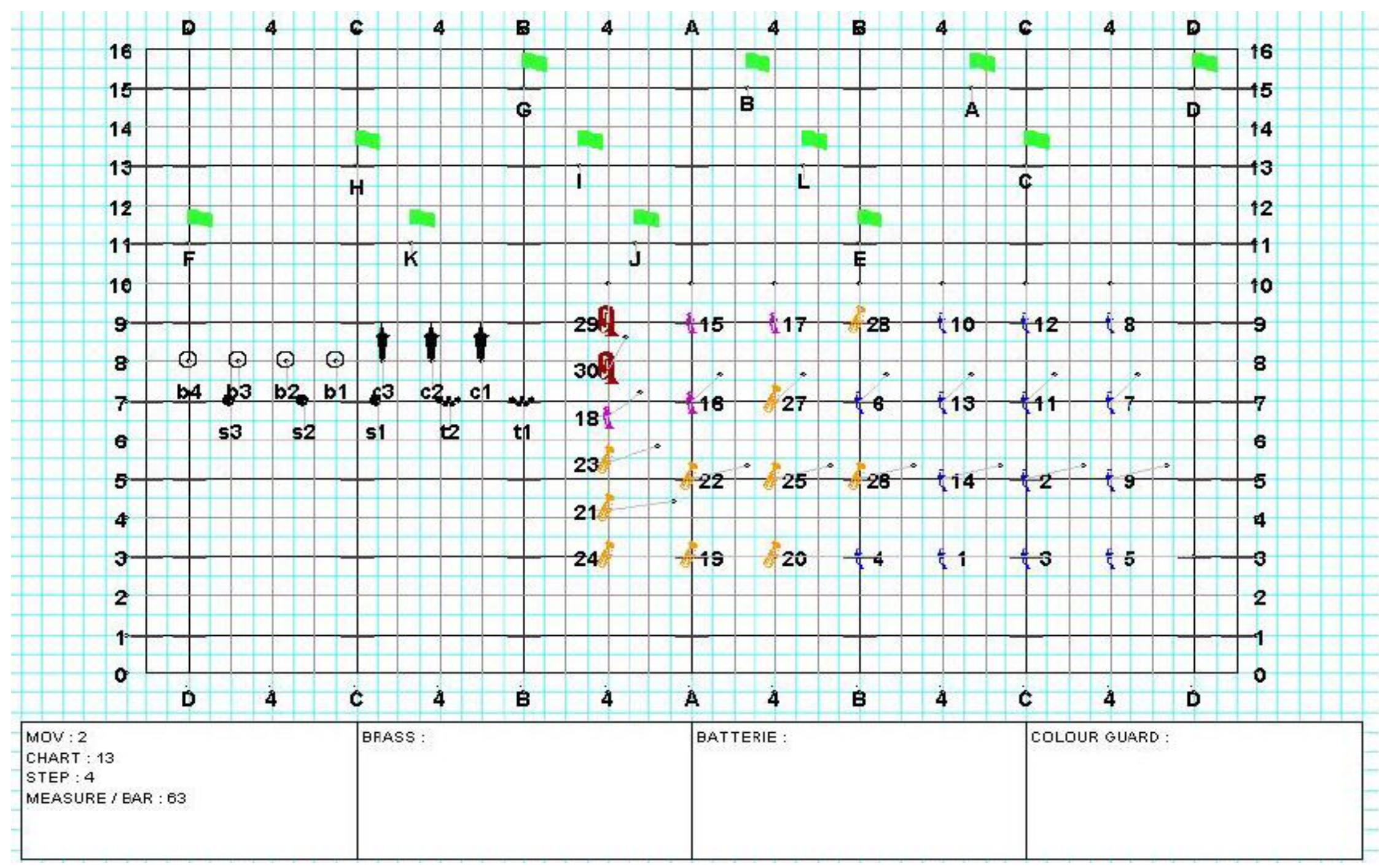




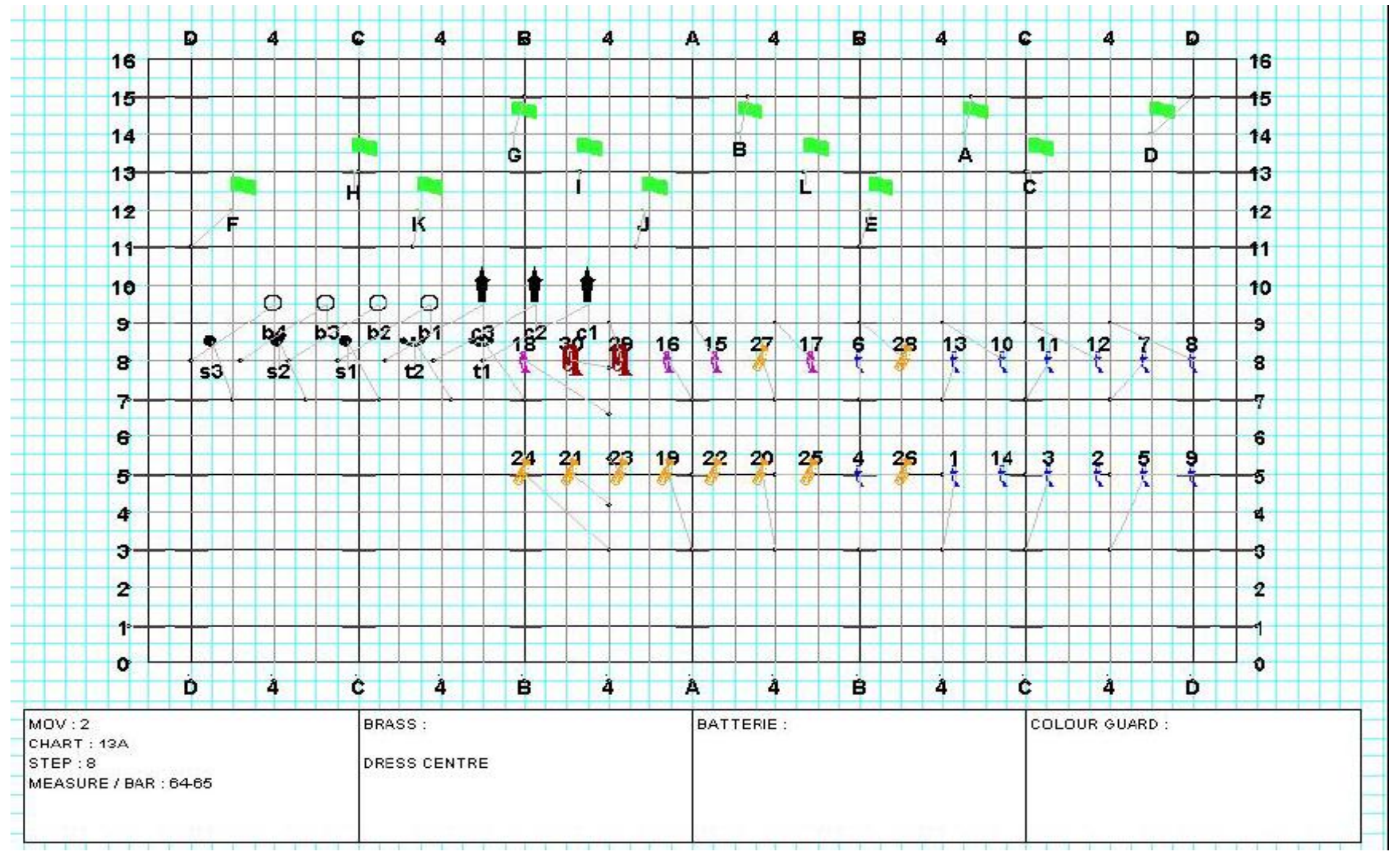




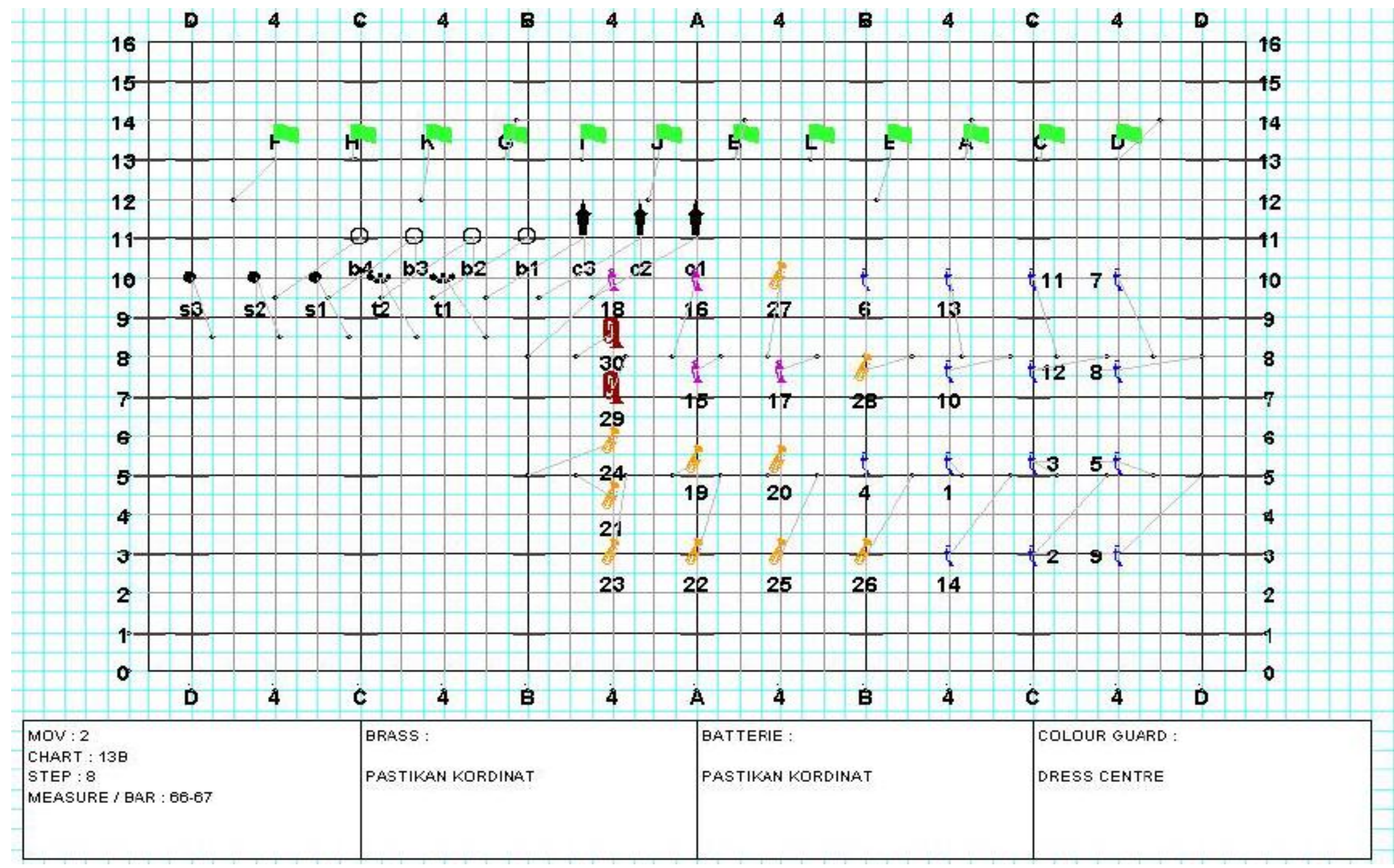




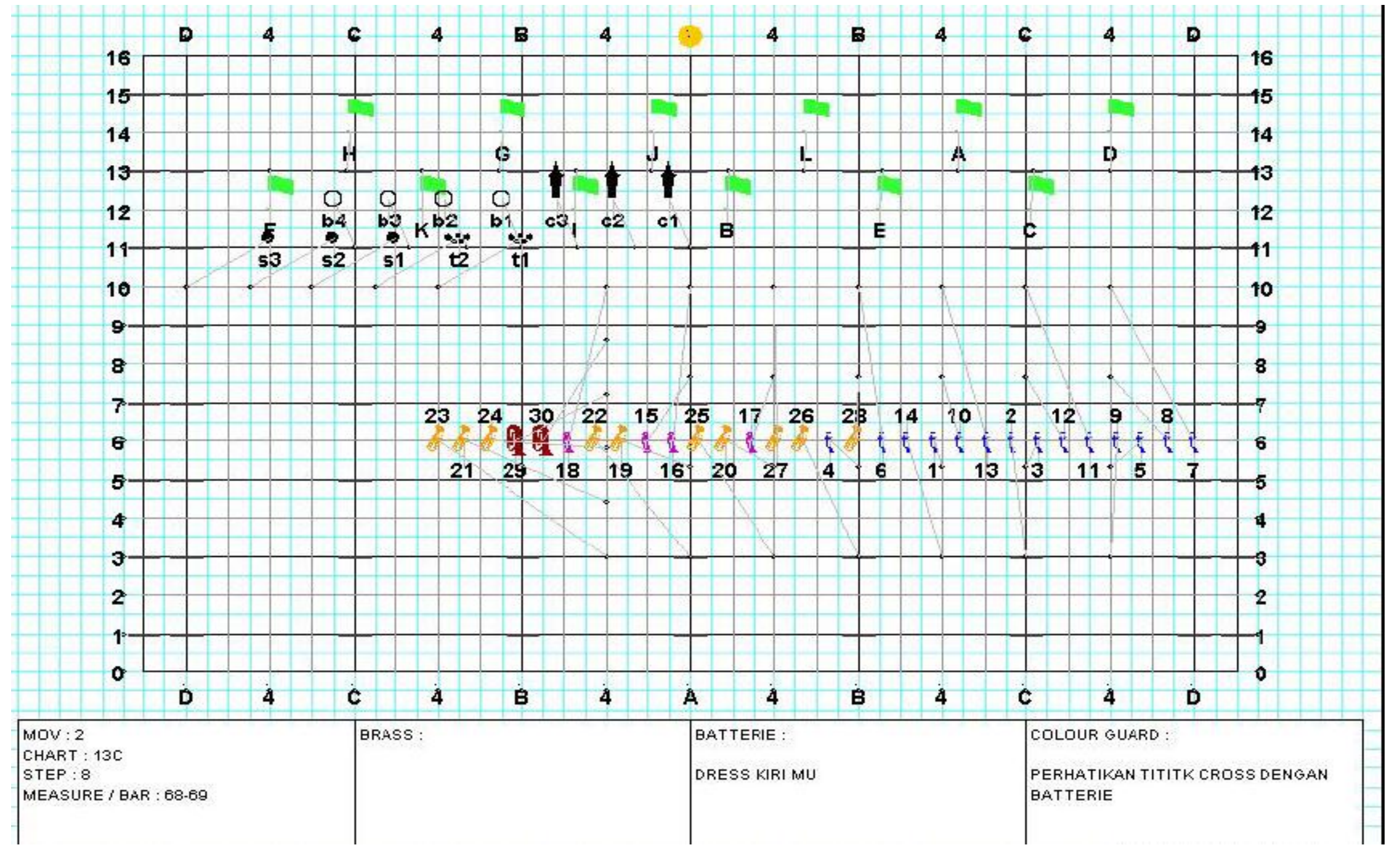




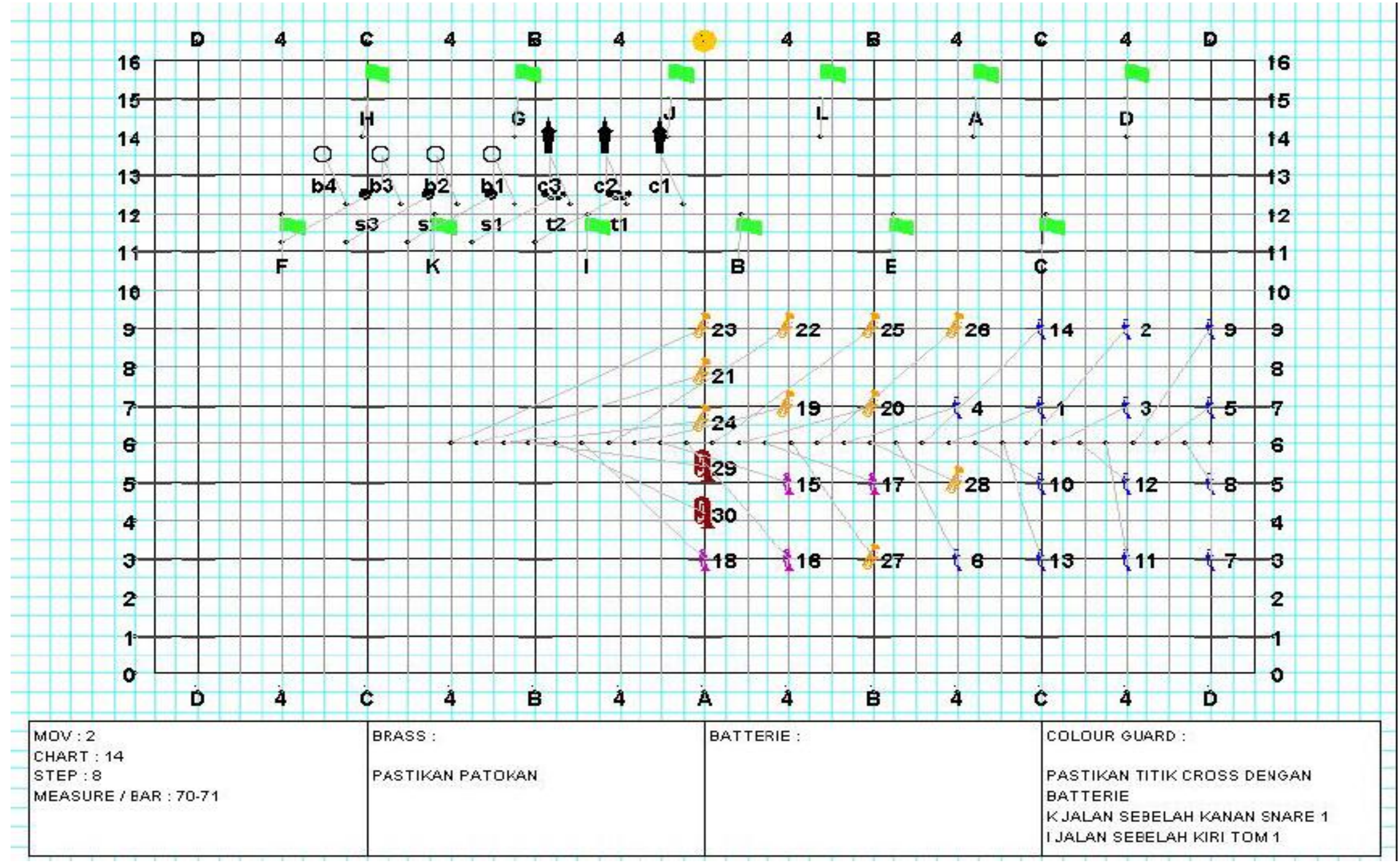




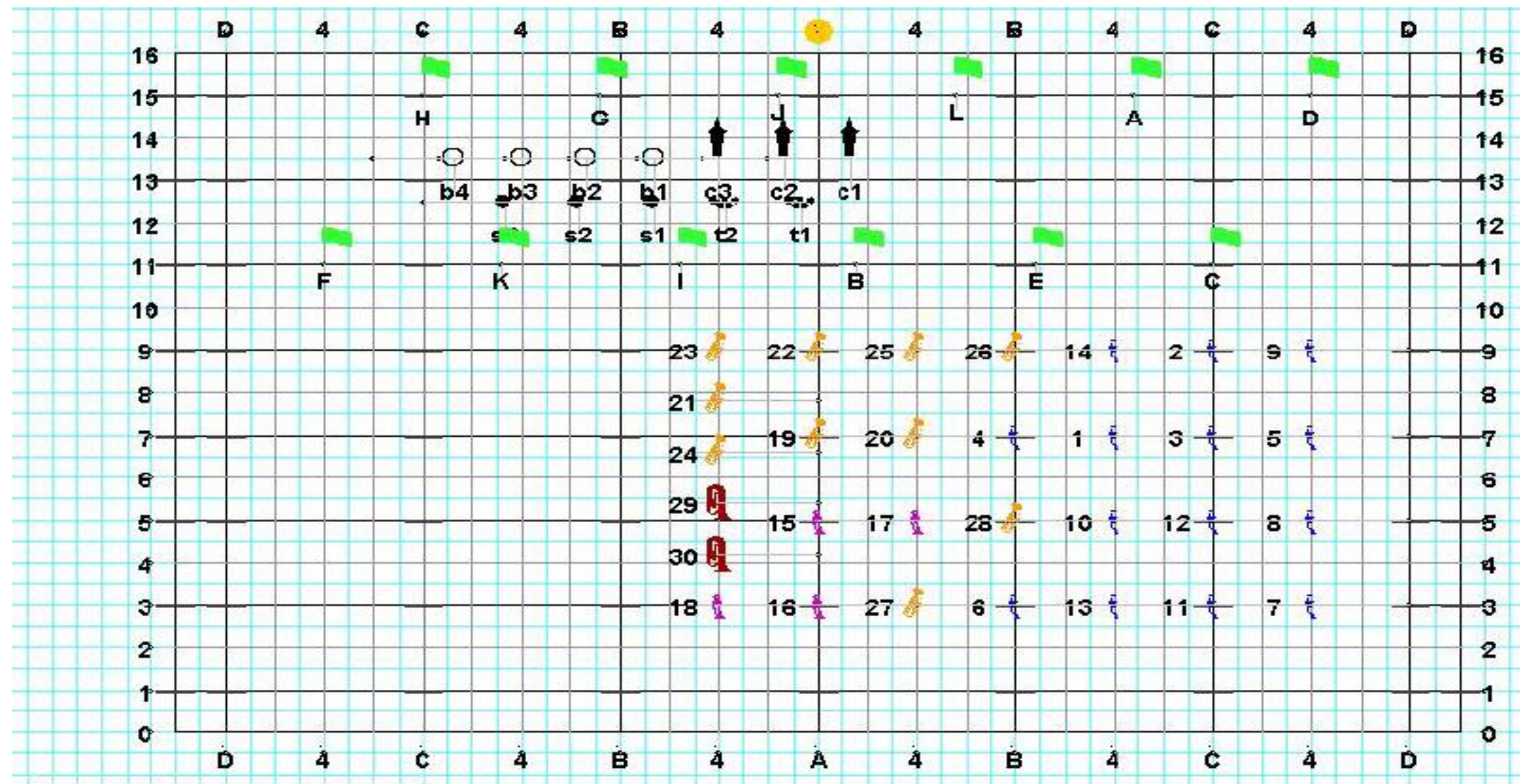

\section{MOV: 2}

CHART : $14 A$

STEP : 8 HALF BEAT/CUT TIME (4)

MEASURE / BAR : 72-73 


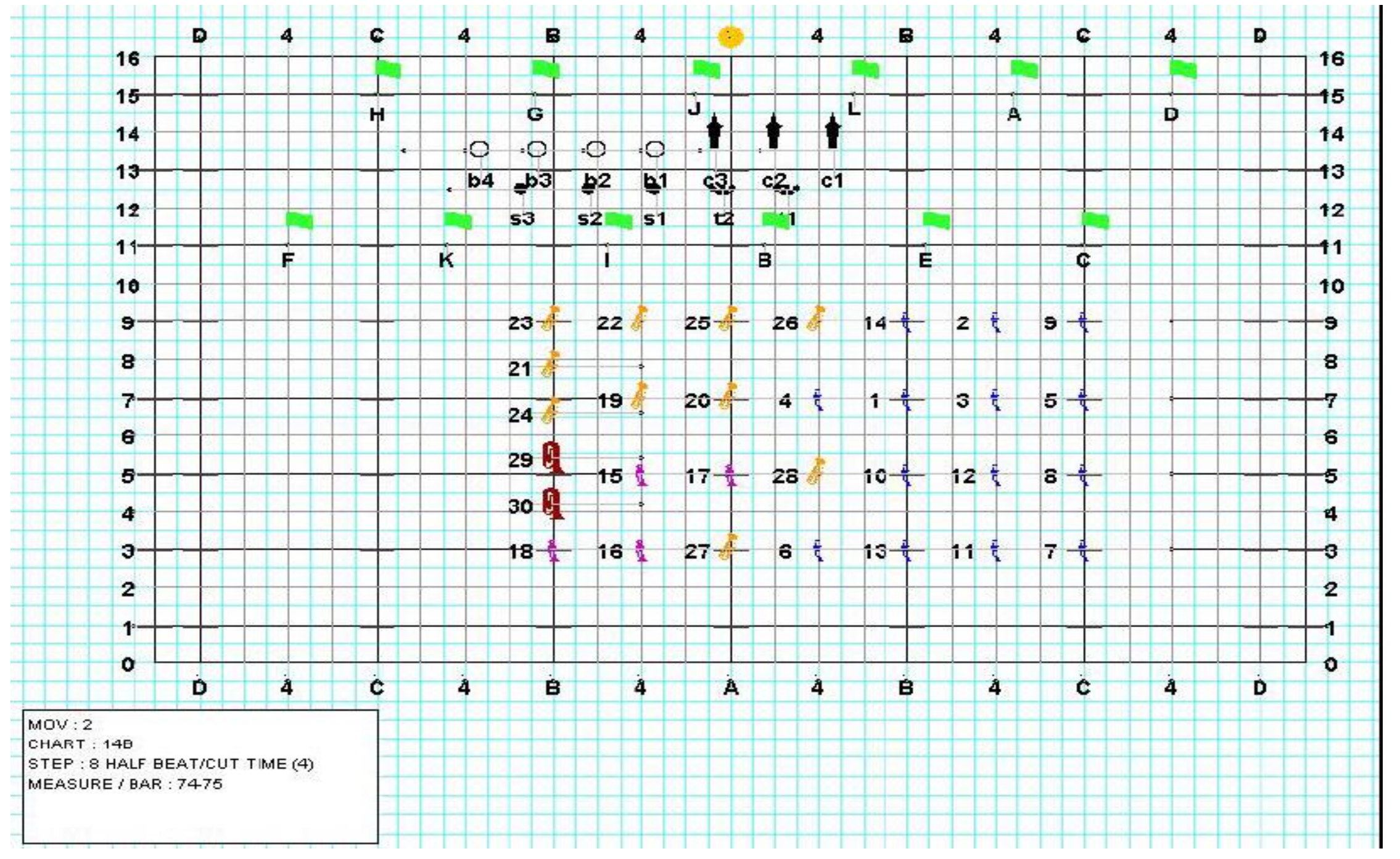




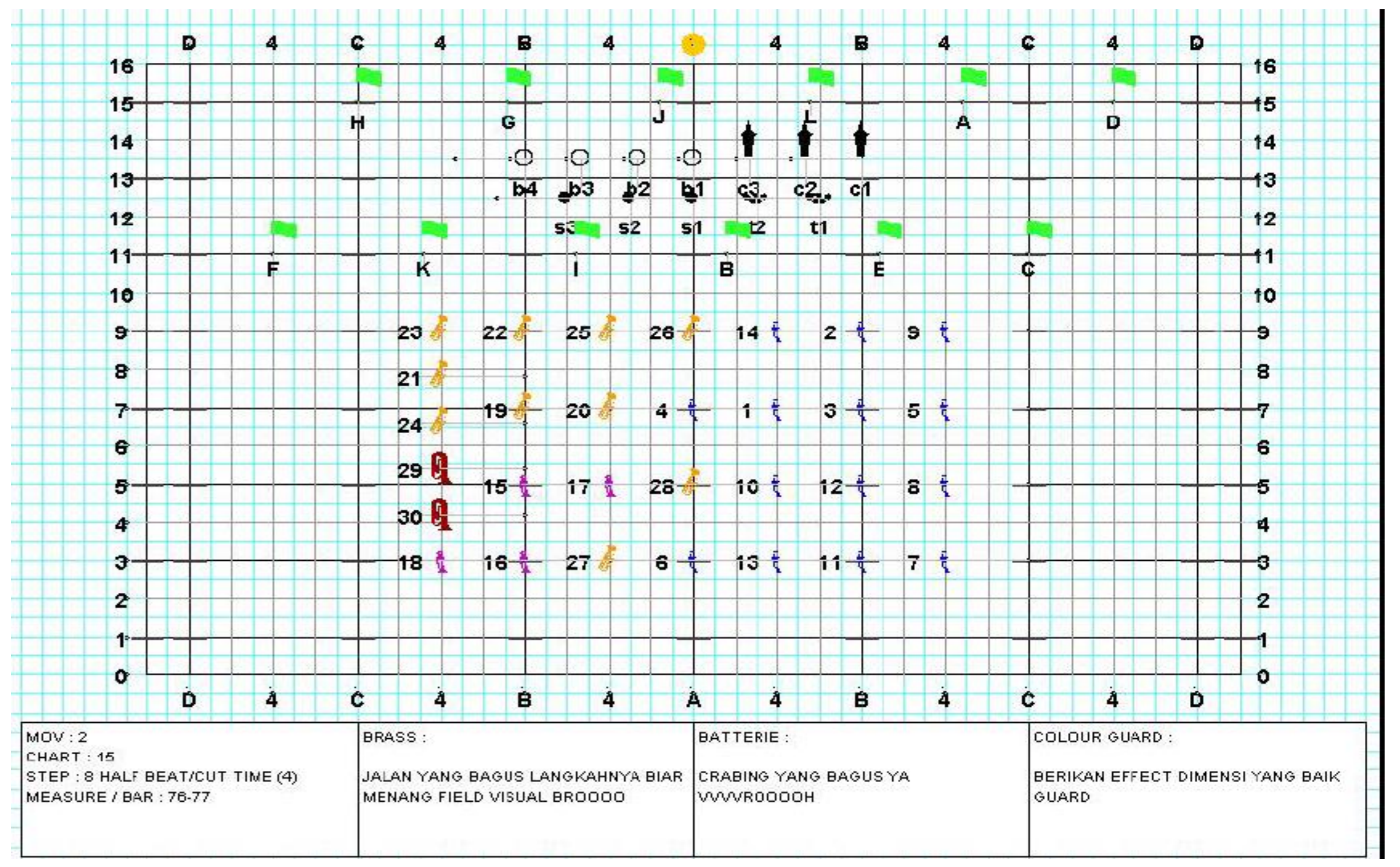




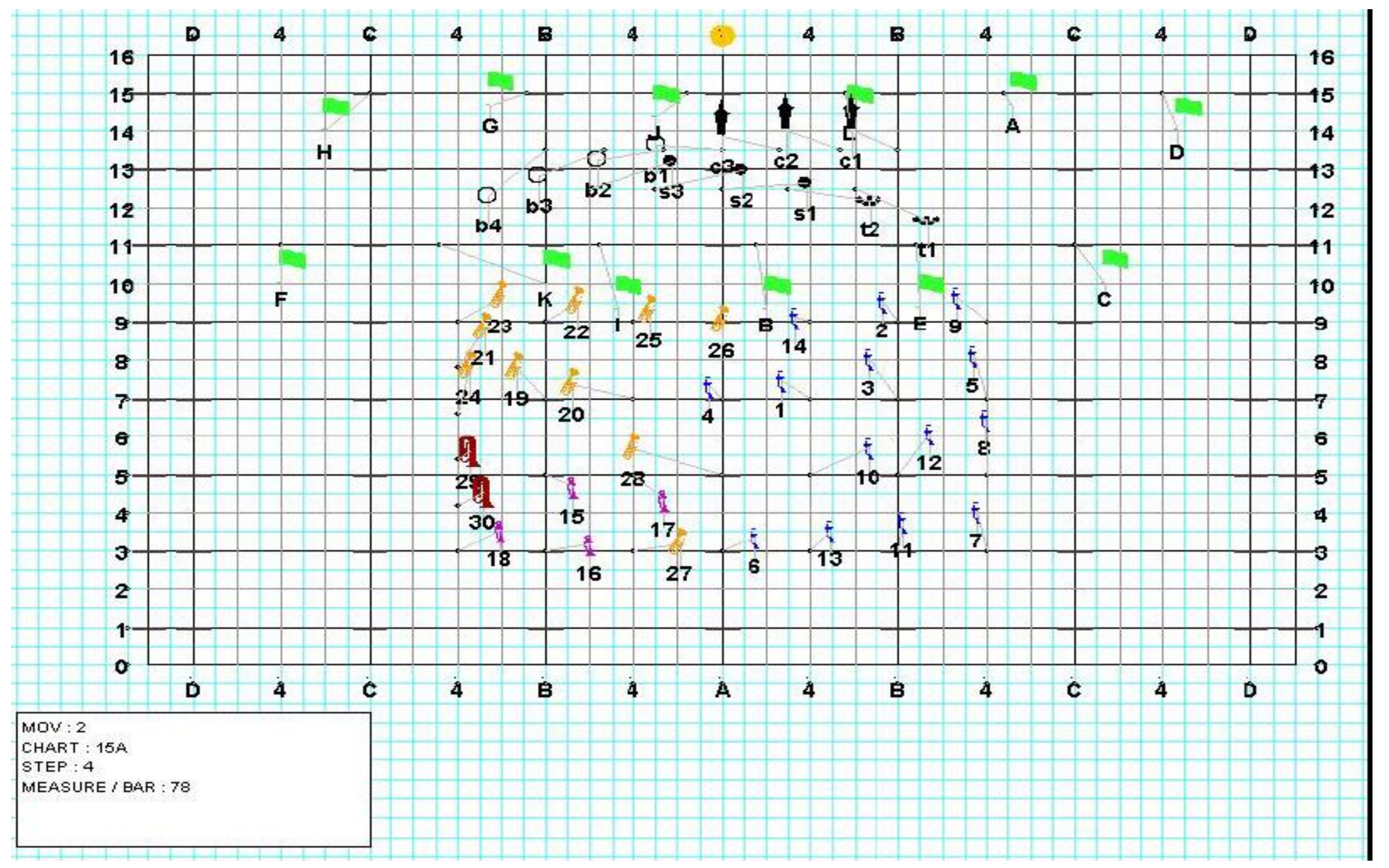




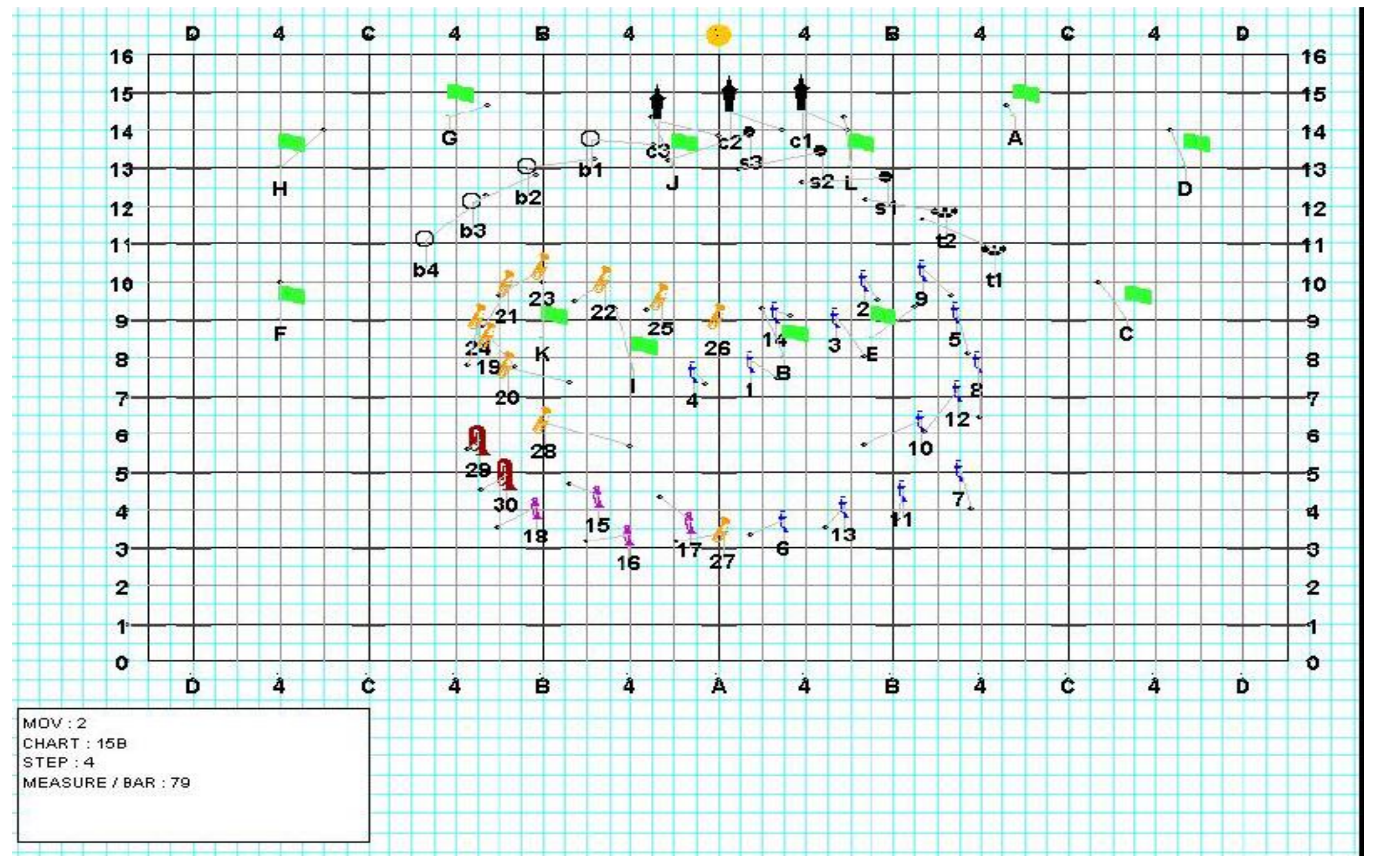




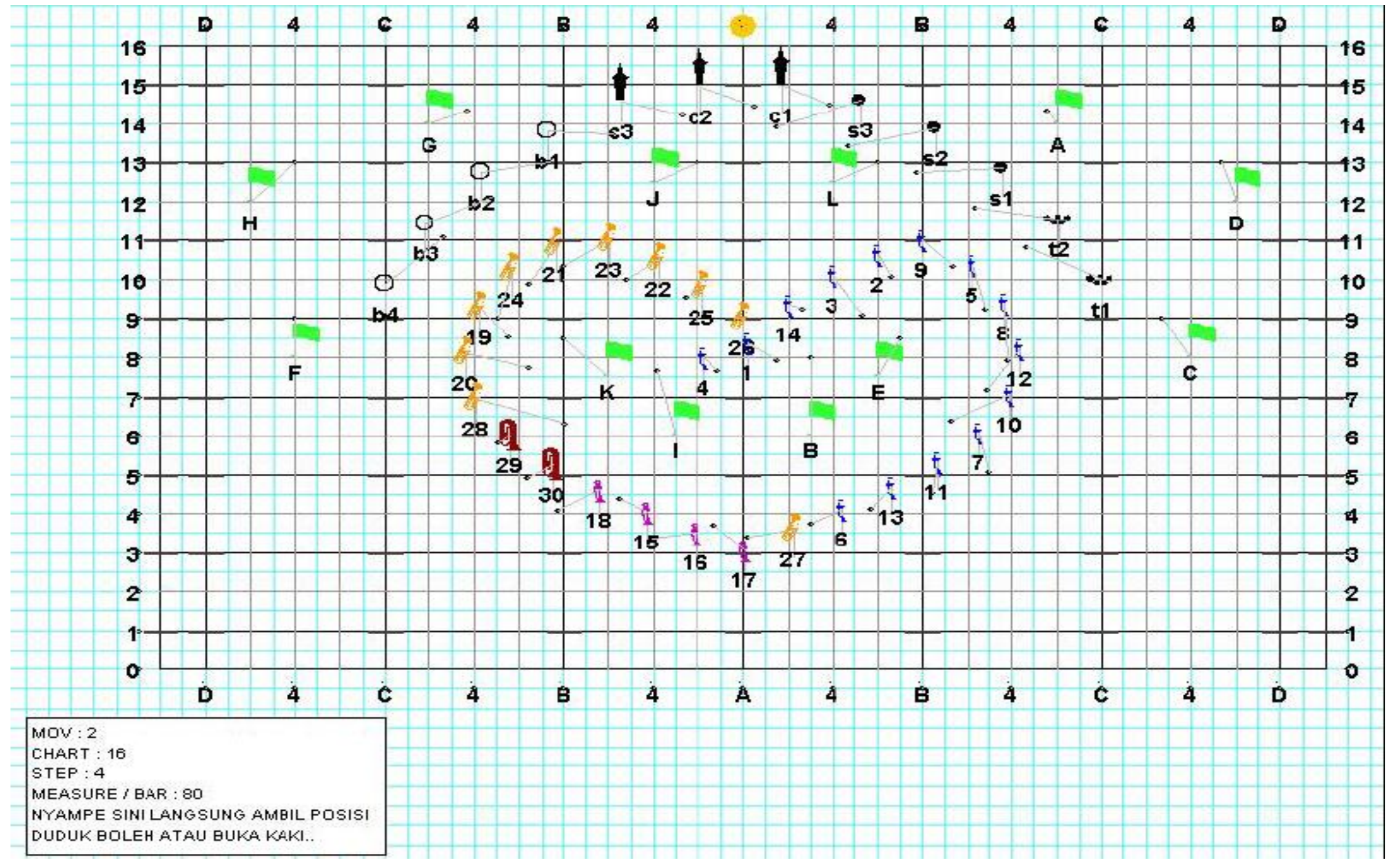




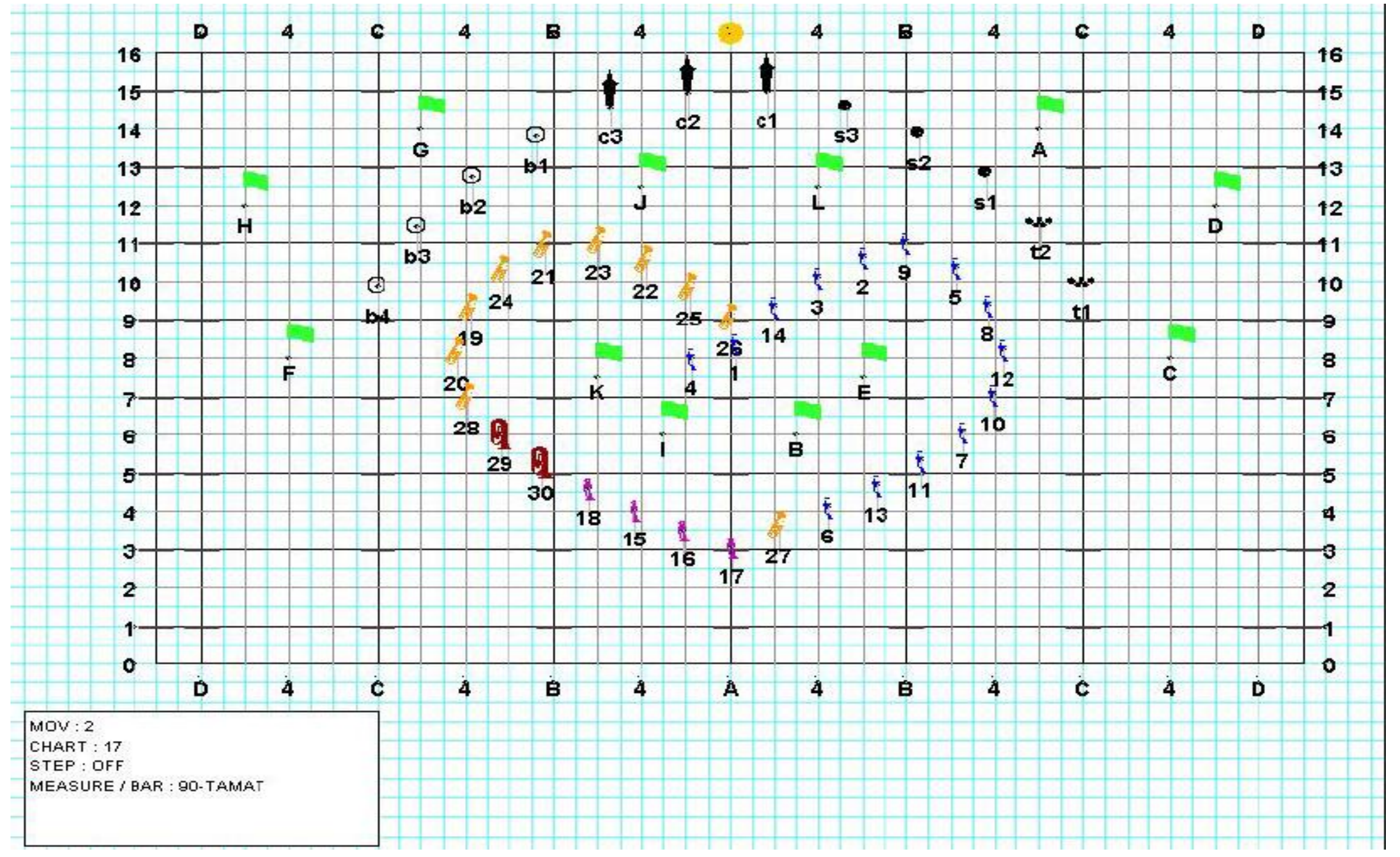

